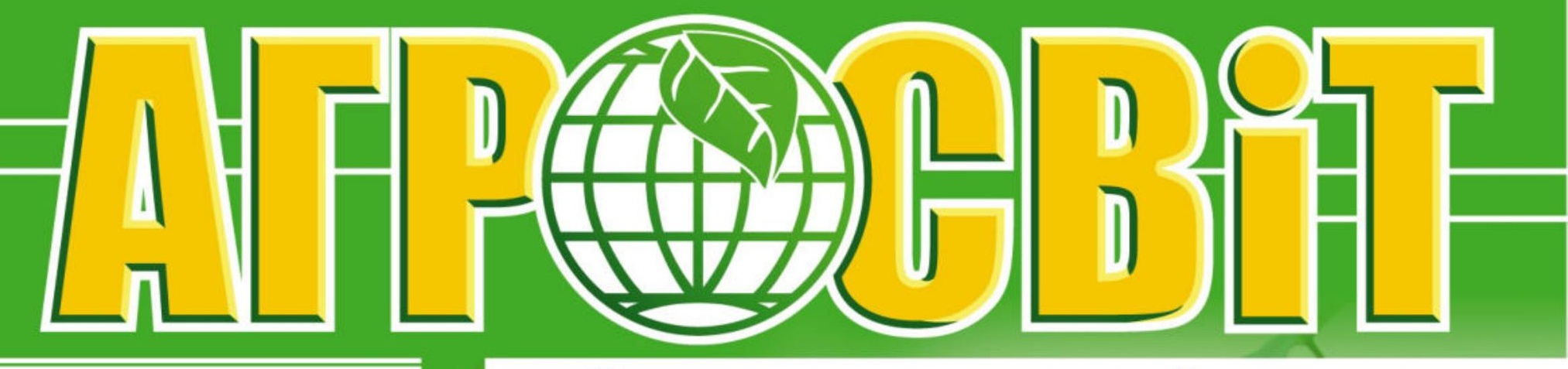

№ 7-8 квітень 2021

Науково-практичний журнал

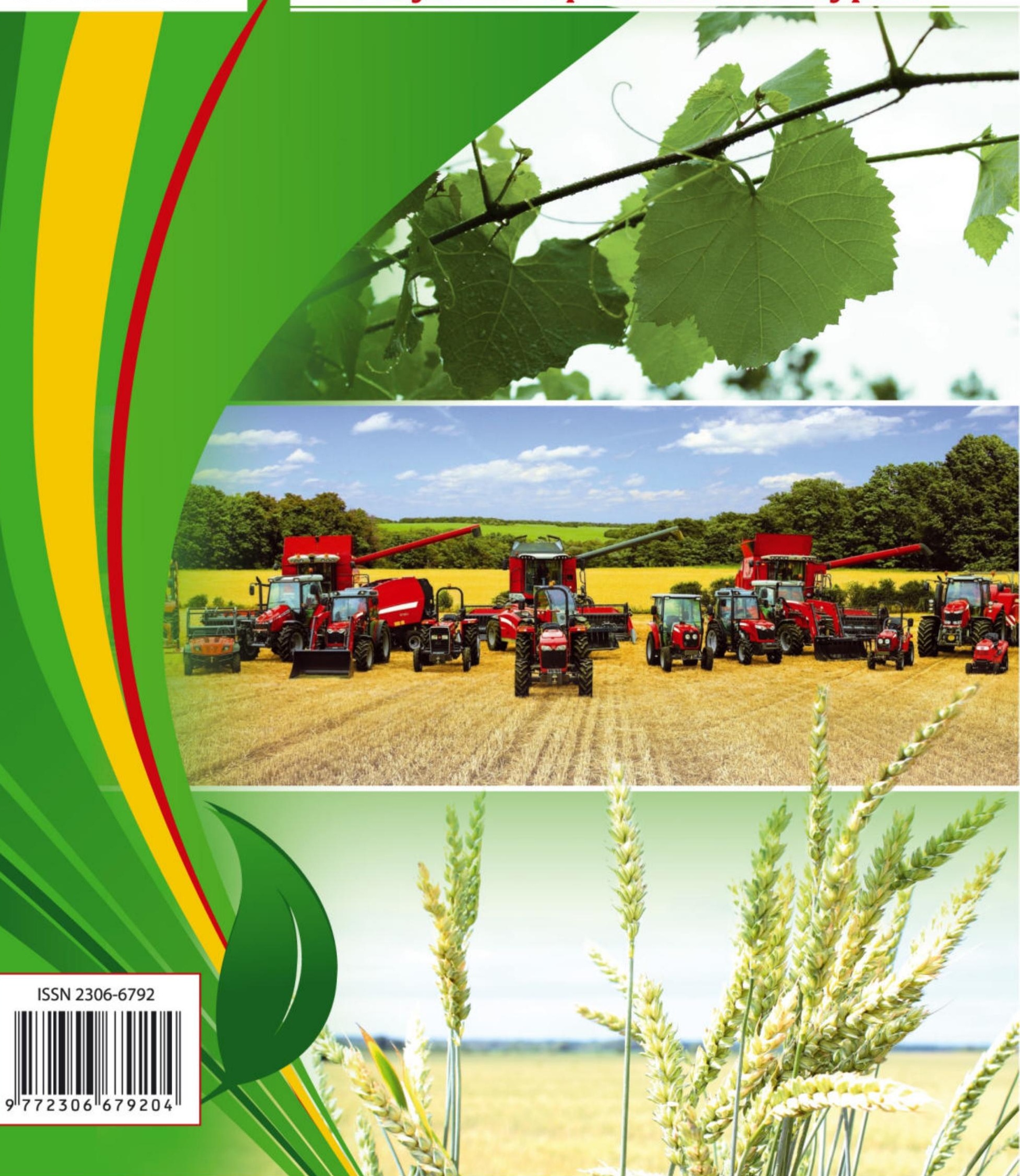


ГОАОВНИЙ РЕААКТОР:

Васильєва Наталя Костянтинівна, доктор економічних наук, професор, завідувач кафедри інформаційних систем і технологій, Аніпровський державний аграрно-економічний університет

\section{ЗАСТУПНИК ГО ООВНОГО РЕААКТОРА:}

Вініченко Ігор Іванович, доктор економічних наук, професор, завідувач кафедри економіки, Аніпровський державний аграрно-економічний університет

ВІАПОВІАААЬНИЙ СЕКРЕТАР: Кучеренко Г. Б.

\section{ЧАЕНИ РЕААКЦІЙНОЇ КОАЕГІЇ:}

Андрющенко Катерина Анатоліївна, доктор економічних наук, доцент, професор кафедри економіки та підприємництва, $\triangle$ ВНЗ «Київський національний економічний університет імені Вадима Гетьмана»

Безус Роман Миколайович, доктор економічних наук, професор, професор кафедри маркетингу, Аніпровський державний аграрно-економічний університет

Гончаренко Оксана Володимирівна, доктор економічних наук, професор, професор кафедри економіки, Аніпровський державний аграрно-економічний університет

Аобровальська Олена Володимирівна, доктор економічних наук, доцент, доцент кафедри фінансів, банківської справи та страхування, Аніпровський державний аграрноекономічний університет

Козловський Сергій Володимирович, доктор економічних наук, професор, професор кафедри підприємництва, корпоративної та просторової економіки, Аонецький національний університет імені Василя Стуса (м. Вінниця)

Крючко Иеся Станіславівна, кандидат економічних наук, доцент, доцент кафедри маркетингу, Аніпровський державний аграрно-економічний університет

Кураташвілі Альфред Анзорович (Тбілісі, Грузія), доктор економічних, філософських і юридичних наук, професор в галузі суспільних наук, професор Грузинського технічного університету в області Публічного права (Факультет Права і Міжнародних відносин), науковий керівник Інституту Бізнесу і Права факультетів Права і Міжнародних відносин і Бізнестехнологій ГТУ, завідувач відділом економічної теорії Інституту економіки імені П.Гугушвілі Тбіліського державного університету імені Іване Ажавахішвілі

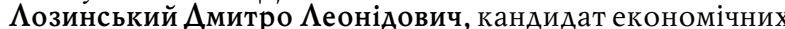
наук, доцент, доцент кафедри обліку і аудиту, Аержавний університет «ЖКитоми рська політехніка»

Павлова Галина Євгеніївна, доктор економічних наук, професор, професор кафедри обліку, оподаткування та управління фінансово-економічною безпекою, Аніпровський державний аграрно-економічний університет

Самойленко Алла Олександрівна, кандидат економічних наук, доцент кафедри менеджменту та туристичного бізнесу, Аніпровський національний університет імені Олеся Гончара

Сардак Сергій Едуардович, доктор економічних наук, доцент, в.о. завідувача кафедри економіки, підприємництва та управління підприємствами, Аніпровський національний університет імені Олеся Гончара

Пантєлєєва Наталія Миколаївна, доктор економічних наук, кандидат технічних наук, доцент, доцент кафедри фінансів та банківської справи, Черкаський навчально-науковий інститут Аержавного вищого навчального закладу «Університет банківської справи»

Трусова Наталя Вікторівна, доктор економічних наук, професор, професор кафедри фінансів, банківської справи та страхування Таврійського державного агротехнологічного університету, Таврійський державний агротехнологічний університет

Федоренко Станіслав Валентинович, кандидат технічних наук, доцент, доцент кафедри охорони праці і навколишнього середовища КНУБА, академік академії будівництва України

Халатур Світлана Миколаївна, доктор економічних наук, професор, професор кафедри фінансів, банківської справи та страхування, Аніпровський державний аграрноекономічний університет

Череп Олександр Григорович, доктор економічних наук, доцент, професор кафедри економіки, Запорізький національний університет

Чирва Ольга Григорівна, доктор економічних наук, професор, професор кафедри маркетингу, менеджменту та управління бізнесом, Уманський державний педагогічний університет імені Павла Тичини

Шабатура Тетяна Сергіївна, кандидат економічних наук, доцент, доцент кафедри економічної теорії і економіки підприємства, Одеський державний аграрний університет

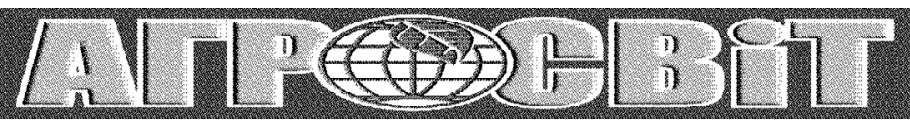

Журнал засновано у січні 2001 року. Виходить 2 рази на місяць.

\section{№ 7-8 квітень 2021 р.}

Журнал включено до Переліку наукових фахових видань України з

ЕКОНОМІЧНИХ НАУК (Категорія «Б»).

Наказ Міністерства освіти і науки України

№ 975 від 11.07.2019 p.

Спеціальності-051,071,072,073,075, 076, 292

ІНАЕКСАЦІЯ ВИААННЯ В НАУКОМЕТРИЧНИХ БАЗАХ:

- Index Copernicus (IC);

- SIS;

- Google Scholar.

Свідоцтво КВ № 23728-13568ПР від 27.12.2018 року

ISSN 2306-6792

Передплатний індекс: 21847

ААреса редакції:

04112, м. Київ, вул. Аорогожицька, 18, к. 29

Поштова адреса:

04112, м. Київ, вул. Аорогожицька, 18, к. 29

Телефон: (044) 223-26-28, 537-14-33

Тел. факс: (044) 458-10-73

E-mail: economy_2008@ukr.net

www.agrosvit.info

Засновники:

Аніпровсъкий державний аграрно-економічний університет, TOB "АКС Центр"

Видавець:

TOB" АКС Центр"

Передрукування дозволяється лише за згодою редакції.

Відповідальність за добір і викладення фактів несуть автори. Редакція не завжди поділяє позицію авторів публікацій. За зміст та достовірність реклами несе відповідальність

рекламодавець.

Рекомендовано до друку Вченою Радою Аніпровського державного аграрно-економічного університету $29.04 .21 \mathrm{p}$.

Підписано до друку 29.04.21 p.

Формат 60х84 1/8, Ум. друк. арк. 17,5. Наклад - 1000 прим.

Папір крейдований, друк офсетний. Замовлення № 2904/1.

Відаруковано у ТОВ «АКС Центр» м. Київ, пров. Куренівський, 17 Тел. (044) 537-14-34

(C) АгроСвіт, 2021 


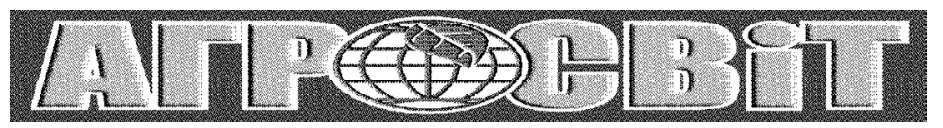

Журнал засновано у січні 2001 року. Виходить 2 рази на місяць.

\section{№ 7-8 квітень 2021 р.}

\section{У HOMEPI:}

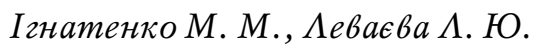

Інклюзивний розвиток агропродовольчих холдингів і корпорацій: напрями і можливості 4

Третяк А. М., Третяк В. М., Полішук А. С.

Особливості оцінки вартості сільськогосподарського землекористування в земельній іпотеці ....

Нусінов В. Я., Буркова А. А.

Оцінювання ймовірності настання банкрутства підприємств з урахуванням горизонту прогнозування .......

Ковальов А. В., Черемісін О. В.

Роль міського самоврядування Півдня України в розвитку торгівлі в другій половині XIX — початку XX ст.

ДачійО.І., Черняєва О.О., Туболещь I. I.

Фінансові ресурси як об'єктивний обмежувач масштабів державного регулювання економіки

та соціальної сфери

Білоткач I. A.

Формування системи інституціонального забезпечення розвитку органічного агропромислового виробництва

Аніпропетровської області .....

Бойко $\Lambda . O$.

Цінова ситуація та огляд ринку овочевих культур "борщового набору"

Герчанівсъка С. В., Петренко Н. I., КачмарО. В.

Сутність і характеристика основних понять ринку праці в соціально-економічній системі

Курбачька А. М., Кадирус I. Г., Савенко О. А., Нечипоренко К. В.

Удосконалення логістичних систем Аля забезпечення принципів стійкого розвитку

підприємства

Масюк Ю. В.

Ключові аспекти інвестиційного забезпечення аграрних підприємств

КрасовськаО. Ю.

Сучасні особливості управління маркетингом послуг суб'єктів господарювання сфери туризму

Ратинсъкий В. В.

Бухгалтерський облік у процесі управління підприємством

Макариук I. М., Перчук О. В., Яременко А. М., Стратан А. В.

Особливості функціонування світового ринку криптовалюти в умовах трансформаційних змін

глобального економічного середовища

Олійник А. С., Вельбой М. Б., Аук' яновець Н. М.

Роль персоналу та виробничих витрат при ефективному управлінні підприємством

Неустроєв Ю. Г.

Роль інновацій у забезпеченні економічної безпеки

Аверчева Н. О.

Економічний аналіз рентабельності молока

Кельман В.А.

Сучасні особливості та моделі адміністрування та управління мережевого ритейлу

Аяшинський В. Б.

Еколого-економічні засади формування нетрадиційного землекористування

в Україні

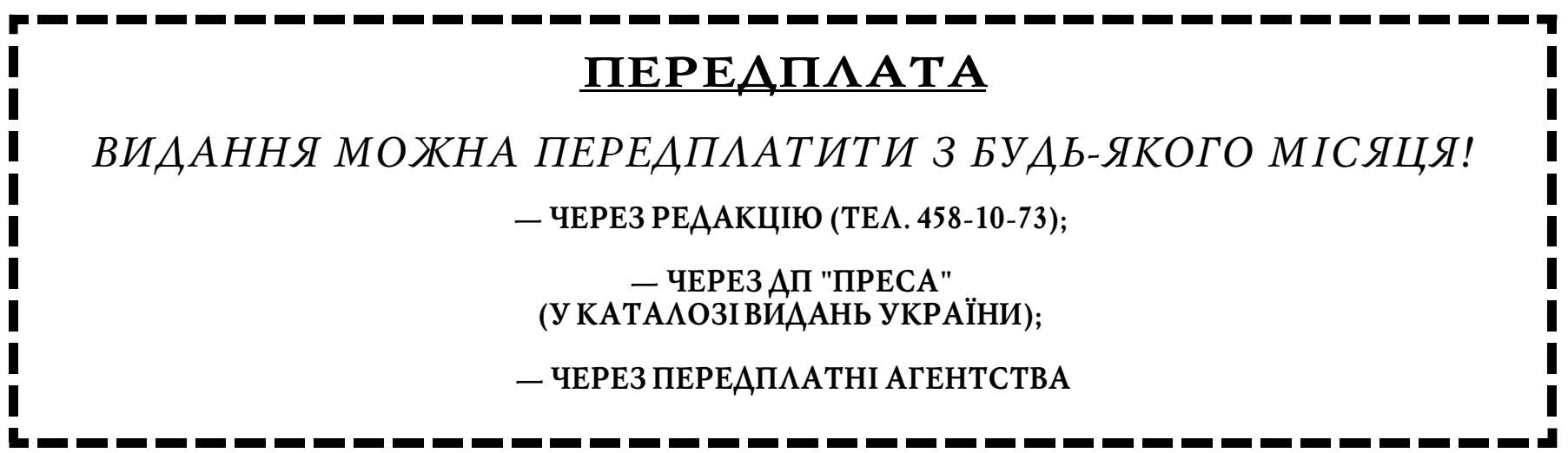




\section{CONTENTS:}

Ihnatenko M., Levaieva L.

INCLUSIVE DEVELOPMENT OF AGRI-FOOD HOLDINGS AND CORPORATIONS:

DIRECT AND OPPORTUNITIES

Tretiak A., Tretiak V., Polishchuk A.

PECULIARITIES OF ESTIMATING THE COST OF AGRICULTURAL LAND USE

IN LAND MORTGAGE

Nusinov V., Burkova L.

ASSESSING THE PROBABILITY OF BANKRUPTCY OF ENTERPRISES TAKING INTO ACCOUNT

THE FORECAST HORIZON

Kovalyov D., Cheremisin O.

THE ROLE OF CITY GOVERNMENT OF THE SOUTH OF UKRAINE IN THE DEVELOPMENT

OF TRADE IN THE SECOND HALF OF XIX - EARLY XX CENTURY

Datsii O., Cherniaieva O., Tubolets I.

FINANCIAL RESOURCES AS AN OBJECTIVE LIMITER ON THE SCALE OF STATE REGULATION

OF THE ECONOMY AND SOCIAL SPHERE

Bilotkach I.

FORMATION OF THE SYSTEM OF INSTITUTIONAL SUPPORT OF DEVELOPMENT OF ORGANIC

AGRO-INDUSTRIAL PRODUCTION OF DNIPROPETROVSK REGION

Boiko L.

THE PRICE SITUATION AND EXAMINATION OF THE MARKET OF VEGETABLE CROPS

OF "BORSHCH SET"

Herchanivska S., Petrenko N., Kachmar O.

ESSENCE AND CHARACTERISTICS OF THE BASIC CONCEPTS OF THE LABOR MARKET

IN THE SOCIO-ECONOMIC SYSTEM

Kurbatska L., Kadyrus I., Savenko O., Nechyporenko K.

IMPROVEMENT OF LOGISTICS SYSTEMS TO ENSURE THE PRINCIPLES OF SUSTAINABLE ENTERPRISE DEVELOPMENT

Masyuk Yu.

KEY ASPECTS OF INVESTMENT SUPPORT OF AGRICULTURAL ENTERPRISES

Krasovska O.

MODERN FEATURES OF MARKETING MANAGEMENT OF SERVICES

OF TOURISM BUSINESS ENTITIES

Ratynskyi V.

ACCOUNTING IN THE ENTERPRISE MANAGEMENT PROCESS

Makarchuk I., Perchuk O., Yaremenko L., Stratan A.

FEATURES OF THE FUNCTIONING OF THE WORLD CRYPTOCURRENCY MARKET IN THE CONTEXT

OF TRANSFORMATIONAL CHANGES IN THE GLOBAL ECONOMIC ENVIRONMENT

Oliinyk A., Velboi M., Lukianovets N.

THE ROLE OF PERSONNEL AND PRODUCTION COSTS IN EFFECTIVE MANAGEMENT

OF THE ENTERPRISE

Neustroiev $Y$.

THE ROLE OF INNOVATION IN ENSURING ECONOMIC SECURITY

Avercheva N.

ECONOMIC ANALYSIS OF MILK PROFITABILITY

Kelman V.

CURRENT FEATURES AND MODELS OF NETWORK RETAIL ADMINISTRATION

AND MANAGEMENT

Lyashynskyy V.

ECOLOGICAL AND ECONOMIC PRINCIPLES OF FORMATION OF NON-CONVENTIONAL

LAND USE IN UKRAINE 
УAK 338.2:330.34

М. М. Ігнатенко,

А. е. н., професор, завідувач кафедри економіки,

Університет Григорія Сковороди у Переяславі, м. Переяслав

ORCID ID: 0000-0002-5713-7951

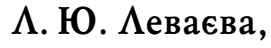

к. е. н., Аоцент, Аоцент кафедри економіки,

Університет Григорія Сковороди у Переяславі, м. Переяслав

ORCID ID: 0000-0003-0697-2700

DOI: $10.32702 / 2306-6792.2021 .7-8.4$

\title{
ІНКЛЮЗИВНИЙ РОЗВИТОК
}

АГРОПРОАОВОАЬЧИХ ХОААИНГІВ І

КОРПОРАЦІЙ: НАПРЯМИ І МОЖЛИВОСТІ

\author{
M. Ihnatenko, \\ Doctor of Economic Sciences, Professor, Head of the Department of Economics, \\ Hryhorii Skovoroda University in Pereiaslav, Pereiaslav \\ L. Levaieva, \\ $\mathrm{PhD}$ in Economics, Associate Professor, Associate Professor of the Department \\ of Economics, Hryhorii Skovoroda University in Pereiaslav, Pereiaslav
}

\section{INCLUSIVE DEVELOPMENT OF AGRI-FOOD HOLDINGS AND CORPORATIONS: DIRECT AND OPPORTUNITIES}

У статті визначено, що в сучасному глобалізованому світі найбільшими проблемами існування людства визначено на найближчу перспективу великий цифровий розрив, з яким можуть зіткнутися мільярди людей через нерівну доступність до новітніх технологій; економічна криза внаслідок пандемії коронавірусу; нестабільна геополітична обстановка; екологічні проблеми потепління, виснаження ресурсів, відходів і забруднення довкілля. Як показує практика, у найбільш вигідному положенні опиняються ті країни, економіка та розвиток яких є соціально орієнтованими, тобто інклюзивними. Встановлено, що велике значення Аля його забезпечення в Україні мають великі агропродовольчі холдинги й корпорації. БуАучи потужними бізнесовими утвореннями, які зосереАжують великий фінансовий $\mathrm{i}$ виробничо-ресурсний потенціал, вони забезпечують виробництво великих обсягів сільськогосподарської сировини й продовольчої продукції, мають надприбутки й здійснюють вивіз капіталів 3 територій свого розміщення та спричиняють значну соціальну нерівність, скорочення місць прикладання праці і зубожіння сільського населення. Тому в статті запропоновано розглядати їх і як Ажерела відновлення соціальної справеАливості та інклюзивного розвитку. Обгрунтовано можливості й напрями інклюзивної діяльності. Розроблено критерії та індикатори Аля оцінки.

The article identifies that in today's globalized world, the biggest challenges to human existence in the near future are the large digital divide that billions of people may face due to unequal access to the latest technologies; economic crisis due to the coronavirus pandemic; unstable geopolitical situation; environmental problems of warming, resource depletion, waste and environmental pollution. As practice shows, the most advantageous countries are those whose economy and development are socially oriented, ie inclusive. It has been established that large agri-food holdings and corporations are of great importance for its provision in Ukraine. As powerful business entities that concentrate great financial and production potential, they ensure the production of large volumes of agricultural raw materials and food 
products, have extra profits and carry out the export of capital from their territories and cause significant social inequality, reduction of jobs and impoverishment of the rural population. Therefore, the article proposes to consider them as sources of restoration of social justice and inclusive development. Possibilities and directions of inclusive activity are substantiated. Criteria and indicators for evaluation have been developed. The most important standards of inclusive development, which must be enshrined in law, may be at the first stage of its implementation of certain standards. This is, for example, the share of gross domestic product (GDP) (as a percentage), which is used to finance health care in terms of providing free medical services (but not below the level specified by law). It is also a share of GDP (as a percentage), which is used to finance free education for citizens (but not below the level defined by law). These indicators are focused not on the minimum required amount of social guarantees for the provision of social goods and services to the population, as is already the case in the current legislation, but on a larger amount. After all, GDP is mainly growing, and its minimum level is used only in emergencies or crises. The proposed standards will ensure the implementation of key points of inclusive growth: comprehensive development of human capital, reduction of inequality and poverty, equal opportunities for people to access resources.

Ключові слова: інклюзивний розвиток, агропродовольчі холдинги й корпорачіи, інклюзивна економіка, потениіал, напрями, можливості, інструменти, індикатори, критерії.

Key words: inclusive development, agri-food holdings and corporations, inclusive economy, potential, directions, opportunities, tools, indicators, criteria.

\section{ПОСТАНОВКА ПРОБЛЕМИ}

У сучасному світі місія будь-якої соціально орієнтованої держави має полягати в знаходженні ідеального балансу між суспільством, державою і бізнесом. Згідно з сучасними економічними теоріями і концепціями, основною рушійною силою в економіці такої країни 3 цією метою є створення умов для соціального розвитку, каркасом якого може служити інклюзивна економіка. Інклюзивна економіка у найбільш широкому розумінні означає забезпечення рівного для всіх людей доступу до економічної незалежності і безперешкодної взаємодії між соціальними групами.

Адже економічне зростання, яке дійсно відбувається завдяки, наприклад, великому бізнесу, не завжди зримо позначається на підвищенні добробуту й покращенні життєдіяльності великих мас населення. Тому актуальним є розуміння інклюзивного потенціалу великих господарюючих суб'єктів, яким чином їх економічне зростання сприятиме процвітанню населення як продуктивної сили, споживача продуктів і послуг та ін. Зокрема, в Україні це значною мірою стосується агропродовольчих холдингів і корпорацій, які значним чином впливають на розвиток сільських територій, життєдіяль- ність сільських жителів, економічне зростання країни загалом.

\section{АНАЛІЗ ОСТАННІХ ДОСЛІДЖЕНЬ І ПУБЛІКАЦІЙ}

Необхідно зазначити, що дослідження проблем інклюзивного розвитку були започатковані за кордоном. В Україні вони вивчаються порівняно недавно. Так, велике значення для продовження таких досліджень мають праці І. Манцурова, О. Павлова, О. Продіус, С. Тютюнникової, $\Lambda$. Федулової та інших відомих науковців. Вони стосуються теоретичних та методологічних засад здійснення інклюзивного розвитку та функціонування інклюзивної економіки. Проте положення про інклюзивні напрями розвитку великих господарюючих суб'єктів, у т.ч. агропродовольчих комплексів і корпорацій, потребують подальших досліджень.

\section{META CTATTI}

Метою статті $€$ визначення інклюзивного потенціалу, напрямів й можливості інклюзивного розвитку агропродовольчих холдингів і корпорацій для покращення умов та підвищення якості життя населення сільських територій України. 


\section{ВИКЛАД ОСНОВНОГО МАТЕРІАЛУ ДОСЛІДЖЕННЯ}

Інклюзивна економіка у теорії та практиці визначається як неоекономіка, постіндустріальна, інформаційна, віртуальна, мережева, інтернет-економіка, економіка знань і т.А. ОАнак названі поняття фіксують або окремі аспекти інклюзивної економіки, або навіть інші концепції [1, с. 192]. ААже її суть, системоутворюючі принципи, кінцева мета і специфічні засоби полягають у забезпеченні відкритості й доступності соціальних, духовних і моральних благ для все більшого числа населення. Загалом для пояснення її проявів можна застосувати метод аналогій.

Так, деякі автори вважають, що інклюзивна економіка належить до класу фрактальних систем, де одні й ті ж важелі діють на різних рівнях деталізації. Можна розглянути кілька груп чинників, що характеризують прояв аналогій в інклюзивній економіці: це фактори, пов'язані із задоволенням потреб людини фізіологічного плану; фактори, що визначають суб'єктивні оцінки особистісного статусу людини (рівень добробуту та ін.); фактори, що визначають соціальний статус людини (положення в суспільстві).

Ао факторів першої групи доцільно віднести доходи населення, обсяги та структуру виробництва, структуру зайнятості і т.А.Ао факторів другої групи можна віднести фізіологічні чинники, що визначають стан людини як біологічного виду (суспільне здоров'я) та суб'єктивні уявлення про особистість [2, с. 113]. Ао факторів третьої групи можна віднести статус людини, що формується соціумом та систему соціальних стандартів, ін. Таким чином, сучасне суспільство - це суспільство інклюзивної економіки, інформації та нових технологій, які $є$ рушійною силою економічного зростання.

Bсе більш поширюваний та динамічний процес впровадження інновацій у життєдіяльність суспільства не тільки економічно розвинених, але і країн, що розвиваються, без сумніву, відкриває потенційні мождивості розвитку як світової, так і національних і регіональних економік. Водночас соціальну політику держави відрізняє ряд особливостей. Вона має справу безпосередньо з людиною і орієнтована на неї. Соціальна політика пов'язана зі сферою розподілу і споживання суспільного продукту.

Спосіб розподілу визначається способом виробництва, але розподільні відносини, будучи відносно автономними, можуть гальмувати, або сприяти процесу виробництва, бути чинни- ком підвищення суспільної продуктивності праці. Водночас специфіка економічної політики полягає в орієнтації на економічне зростання і примноження матеріального багатства [3, c. 62]. Звідси випливає, що так само, як соціальна сфера суспільства невіддільна від економіки, соціальна політика держави невіддільна від економічної політики, вони тісно пов'язані між собою.

Ïх діалектичний взаємозв'язок пояснюється тим, що мета економічної політики - регулювання діяльності людей по створенню матеріальних благ і послуг як найважливішої умови зростання народного добробуту, а соціальна політика впливає на відносини між людьми у споживанні ними матеріальних благ і послуг, спрямована на поліпшення умов життя і всебічне особистісне вдосконалення всіх членів суспільства, виходячи з принципу соціальної справедливості. Іншими словами, те, що для однієї політики є підсумком, для іншої - вихідним пунктом.

Отже, можна виділити два підходи: політико-економічний та інституційний. Якщо XX ст. економісти назвали століттям формування середнього класу, то XXI ст. - епохою розшарування суспільства. Аоходи більшості населення навіть розвинених країн на порядок відстають від темпів зростання економіки. У світлі розвитку інклюзивної економіки кожна людина повинна мати доступ до основних потреб для підтримки своєї життєдіяльності: їжі, води, одягу і взуття, охорони здоров'я, житла, освіти, енергоресурсів. Компанії по всьому світу вносять істотний внесок у здійснення поставленого завдання.

Ми вважаємо, що агропродовольчі холдинги й корпорації, які зосереджують великі масиви землі в Україні й застосовують нові технології її обробітку, мають здійснювати соціальну відповідальність насамперед щодо сільських жителів, які внаслідок згортання місць прикладання праці залишилися без роботи, соціального статусу і змушені або емігрувати, або вести особисте господарство [4, c. 12]. Великий агробізнес спільно з місцевими районними адміністраціями або навіть об'єднаними територіальними громадами має визначити перелік постійних та періодичних і тимчасових завдань, якими він має опікуватися.

Мова може йти про виробничі й інфраструктурні проекти (відкриття або відновлення нових виробництв; будівництво нових доріг; культурних, мистецьких, спортивно-оздоровчих закладів тощо); охорону порядку й протидію 
корупції, тіньовій економіці; навчання, перепідготовку й особистісний розвиток молоді, сільських жителів; сприяння розвитку альтернативної діяльності на селі. I, безумовно, це виробництво екологічно чистої, безпечної та якісної продовольчої продукції, доступної за цінами для великої кількості споживачів [5, c. 107]. Безумовно, в її структурі мають бути і преміальні, й економні сегменти. На жаль, до Глобального договору ООН про соціальну відповідальність приєдналося тільки 146 вітчизняних компаній, а звіти про її здійснення подають менше третини 3 них.

Це свідчить про те, що національні агропродовольчі холдинги й корпорації не повністю використовують наявний ресурсний потенціал Аля здійснення соціальної відповідальності й інклюзивного розвитку. Їх власники, часто проживаючи за кордоном, не розуміють нагальних потреб сільських місцевостей розміщення свого бізнесу. Зареєстровані в офшорах, такі підприємства часто сплачують і мінімальні податки, які не дозволяють вирішувати сільські проблеми. Натомість ї діяльність спричиняє виснаження грунтів, виникнення екологічних проблем, руйнування автошляхів, інших інфраструктурних об'єктів загального користування, а лобізм на аграрному ринку має такі негативні наслідки, як зневіру людей у справедливість, віру у соціальні ліфти, відбирає надію на майбутнє тощо.

Тому велике значення має обгрунтування й використання таких інструментів і механізмів, які б заохочували великі агропродовольчі холдинги й корпорації до підтримки інклюзивного розвитку. Одним 3 них може бути державно-приватне партнерство у вирішенні регіональних та галузевих проблем [6, с. 82]. Також це може бути товарне кредитування малого агробізнесу великим; фінансова й кадрова підтримка холдингами й корпораціями бакалаврських і магістерських програм в аграрних університетах; участь у волонтерських проектах та ініціативах; підтримка окремих талановитих людей, особливо дітей та молоді. Також це могла б бути адресна допомога малоімущим групам сільських жителів, пенсіонерам, сиротам. Велике значення для окремих сільських громад і для суспільства взагалі мала б участь таких потужних підприємств в охороні і відтворенні природи, захисті тварин [7, с. 107].

У направленості й оцінці такої діяльності агропродовольчих холдингів і корпорацій доцільно орієнтуватися на певні критерії, показники й індикатори. Так, це може бути індекс інклюзивного розвитку. В свою чергу він грун- тується на 12 індикаторах, об'єднаних в три групи, які оцінюють рівень економічного розвитку: зростання і розвиток (включаючи зростання ВВП, зайнятості, продуктивності праці, очікуваної тривалості життя); інклюзивність (медіанний дохід домогосподарств, рівень бідності та нерівності); справедливість між поколіннями і стійкість (рівень заощаджень, демографічного навантаження, державного боргу і забруднення навколишнього середовища).

Такий індекс відображає більш цілісну картину економічного розвитку, тобто тренд стійкого підвищення рівня життя населення [8, с. 15]. Міжнародні порівняння показують, що більшою стійкістю до зовнішніх загроз і економічних криз характеризуються країни з більшою інклюзивністю соціально-економічної системи, в яких пріоритетом виступає вирішення соціальних проблем у суспільстві і формування державної політики, спрямованої на соціальний захист окремих соціальних категорій населення і вирівнювання доходів.

Механізмами та інструментами підвищення інклюзивності можуть виступати: 1. Установка на соціальну інтеграцію та досягнення рівності загальних благ. 2. Розвиток місцевого самоврядування, громадянського суспільства як гаранта справедливості та соціального захисту. 3. Забезпечення пріоритетного розвитку охорони здоров'я і освіти та підвищення загального доступу до засобів охорони здоров'я, освіти, включаючи додатковий рівень і культуру [9, с. 22]. Реалізація проінклюзівних рішень спрямована на адекватні перетворення механізмів функціонування як держави, так і іii окремих інститутів.

Експерти Всесвітнього економічного форуму (WEF), намагаючись створити цілісну картину економічного розвитку, заклали основи системного підходу до оцінки економічного розвитку країн світу. Водночас розроблений ними індекс інклюзивного розвитку є показником, що характеризує розвиток країни. У наукових публікаціях вже $є$ розробки часткових індексів інклюзивного розвитку стосовно окремих галузей економіки. Так, Ємельяненко $\Lambda . M$. , визначаючи рейтинг інклюзивного розвитку економіки сільського господарства регіонів, пропонує 22 показники, розподілених за чотирма групами [10, c. 129]. Загалом відповідно до логіки системного підходу, необхідно конкретизувати індекс інклюзивного розвитку країни і доповнити його низкою найбільш показових часткових індексів. 
Аля України пріоритетним напрямом визначення таких часткових показників могла б стати розробка індексів для галузей з низькою доданою вартістю (наприклад, таких, як сільське господарство, інфраструктурний комплекс, туристично-рекреаційний комплекс та ін.). Вибір галузей з низькою доданою вартістю пояснюється тим, що їх частка в структурі економіки України зростає і до того ж вони мають і створюють багато робочих місць, не вимагаючи високої кваліфікації робочої сили. Аругим кроком у процесі створення системи часткових індексів інклюзивного розвитку є розробка відповідного інтегрального індексу для промисловості.

Потім слід визначити об'єкти, стосовно яких будуть визначатися зазначені індекси. Це можуть бути як окремі адміністративні області, так і економічні райони. Після відповідних розрахунків часткових індексів інклюзивного розвитку необхідно спостерігати за їх динамікою і розробляти відповідні національні програми і пропозиції по проведенню коригування структурної політики держави згідно виявлених тенденцій та у відповідь на глобальні виклики. На думку експертів WEF, найближчим часом всі країни світу тією або іншою мірою спіткає цифровий розрив через різну доступність населення до новітніх технологій; економічна криза як наслідок пандемії коронавірусу; глобальні екологічні проблеми [11, с. 84].

Аля України, яка зайняла у 2018 р. 49 місце за індексом інклюзивного розвитку в рейтингу економік, що розвиваються і 78 місце серед всіх 107 країн, з яких перші 29 - це країни з розвиненою економікою (тобто Україна знаходиться в останній третині списку) розробка комплексу заходів щодо підвищення інклюзивності, справедливості і стійкості має особливо важливе значення. Слід зазначити, що в країні діє система державних мінімальних соціальних стандартів, що розуміються як встановлений законом мінімально необхідний обсяг соціальних гарантій надання населенню соціальних благ і послуг [12, с. 14]. Вони фінансуються 3 бюджетів різного рівня; їх розмір періодично переглядається через зміну ресурсних можливостей економіки, інфляцію. Однак часто соціальні нормативи існують якби самі по собі і не завжди узгоджуються з економічним прогресом. Стандарти інкдюзивного розвитку починають розроблятися 3 переходом до інклюзивної моделі стійкого зростання.

\section{вИсновки}

Найваждивішими стандартами інкдюзивного розвитку, які повинні бути закріплені пра- вовими нормами, можуть бути на першому етапі його здійснення певні нормативи. Це, наприклад, частка валового внутрішнього продукту (ВВП) (у відсотковому відношенні), що спрямовується на фінансування охорони здоров'я в частині надання безкоштовних медичних послуг (але не нижче визначеного в законі рівня). Також це частка ВВП (у відсотковому відношенні), що спрямовується на фінансування безкоштовної для громадян освіти (але не нижче визначеного в законі рівня).

Наведені показники зорієнтовані не на мінімально необхідний обсяг соціальних гарантій надання населенню соціальних благ i послуг, як це вже має місце в чинному законодавстві, а на більший обсяг. Адже ВВП, в основному, зростає, а його мінімальний рівень застосовується тільки в надзвичайних або кризових ситуаціях. Пропоновані нормативи забезпечать реалізацію ключових моментів інклюзивного зростання: всебічний розвиток людського капіталу, скорочення нерівності і бідності, рівність можливостей людей в отриманні доступу до ресурсів.

\section{$\Lambda$ iтература:}

1. Прогнімак О.А. Інклюзивний розвиток $\mathrm{V}_{\mathrm{K}}$ раїни: Перешкоди VS перспективи. Економічний вісник Аонбасу. 2018. № 1 (51). С. 187-197.

2. Ігнатенко М.М., Бритвєнко А.С. Виробничий і маркетинговий потенціал аграрних підприємств і корпорацій на ринку продовольчої продукції. Причорноморські економічні студії: наук. жур. Вип. 40. 2019. С. 112-115.

3. Федулова $\Lambda$.І. Інклюзивні інновації в системі соціально-економічного розвитку. Економіка: реалії часу. 2016. № 3 (25). С. 56-65.

4. Єрмак С.О.Аескриптивні характеристики інклюзивного зростання як інноваційного вектора соціально-економічного розвитку країни. Проблеми економіки. 2017. № 1 (4). С. 8-14.

5. Романюк I.А.Аержавна соціальна політика в забезпеченні продуктивної зайнятості сільського населення. Економіка АПК. 2014. № 10. C. 105-109.

6. Манцуров І.Г. Інклюзивний розвиток як основа протидії глобальним викликам сьогодення. Економіка України. 2018. № 10. С. 71-87.

7. Тютюнникова С.В., Пивоварова К.А. Інклюзивний розвиток національної економіки як чинник подолання бідності. Бізнес Інформ. 2018. № 8. С. 105-111.

8. Ігнатенко М.М., Мармуль А.О. Концептуальні засади стратегічного управління розвитком аграрних підприємств. Матеріали Міжнародної науково-практичної конференції 
"Сучасний маркетинг: стратегічне управління та інноваційний розвиток": до 90-річчя заснування ХНТУСГ, 30 квітня 2020 р. Харків: ХНТУСГ, 2020. С. 14-16.

9. Базилюк А.В., Жулин О.В. Інклюзивне зростання як основа соціально-економічного розвитку. Економіка та управління на транспорті. 2015. № 1. С. 19-29.

10. Емельяненко А.М. Проблеми та перспективи соціально орієнтованого інклюзивного розвитку в Україні. Соціально-трудові відносини: теорія та практика. 2017. № 1. С. 125-134.

11. Продіус O.I. Інклюзивні інновації в контексті соціальної відповідальності підприємств. Науковий вісник Ужгородського національного університету. 2017. № 14. Ч. 2. С. 84-88.

12. Ігнатенко М.М., Мармуль М.О. Фінансові й інвестиційні джерела та ресурси забезпечення конкурентоспроможності підприємств агропродовольчої сфери економіки. Економічний вісник університету. Вип. 44. 2020. С. 13-18.

\section{References:}

1. Prohnimak, O.D. (2018), "Inclusive development of Ukraine: obstacles to vs perspectives", Ekonomichnyy visnyk Donbasu, vol. 1 (51), pp. $187-197$.

2. Ihnatenko, M.M. and Brytvyenko, A.S. (2019), "Production and marketing potential of agricultural enterprises and corporations in the food market", Prychornomors'ki ekonomichni studiyi, vol. 40, pp. $112-115$.

3. Fedulova, L.I. (2016), "Inclusive innovations in the system of socio-economic development", Ekonomika: realiyi chasu, vol. 3 (25), pp. 56-65.

4. Yermak, S.O. (2017), "Descriptive characteristics of inclusive growth as an innovative vector of socio-economic development of the country", Problemy ekonomiky, vol. 1 (4), pp. 8-14.

5. Romaniuk, I.A. (2014), "State social policy in ensuring productive employment of the rural population", Ekonomika APK, vol. 10, pp. 105-109.

6. Mantsurov, I.H. (2018), "Inclusive development as a basis for counteracting today's global challenges", Ekonomika Ukrayiny, vol. 10, pp. 71-87.

7. Tyutyunnykova, S.V. and Pyvovarova, K.L. (2018), "Inclusive development of the national economy as a factor in overcoming poverty", Biznes Inform, vol. 8, pp. 105-111.

8. Ihnatenko, M.M. and Marmul', L.O. (2020), "Conceptual principles of strategic management of agricultural enterprises development", Suchasnyy marketynh: stratehichne upravlinnya ta innovatsiynyy rozvytok. Materialy Mizhnarodnoyi naukovopraktychnoyi konferentsiyi [Modern Marketing: Strategic Management and Innovative Development.
International Scientific and Practical Conference]. KHNTUSH, Kharkiv, Ukraine, pp. 14-16.

9. Bazylyuk, A.V. and Zhulyn, O.V. (2015), "Inclusive growth as a basis for socio-economic development", Ekonomika ta upravlinnya na transporti, vol. 1, pp. 19-29.

10. Yemel'yanenko, L.M. (2017), "Problems and prospects of socially oriented inclusive development in Ukraine", Sotsial'no-trudovi vidnosyny: teoriya ta praktyka, vol. 1, pp. 125-134.

11. Prodius, O.I. (2017), "Inclusive innovations in the context of corporate social responsibility", Naukovyy visnyk Uzhhorods'koho natsional'noho universytetu, vol. 14, no. 2, pp. 84-88.

12. Ihnatenko, M.M. and Marmul', L.O. (2020), "Financial and investment sources and resources to ensure the competitiveness of agri-food enterprises", Ekonomichnyy visnyk universytetu, vol. 44, pp. 13-18.

Стаття надійшла до редакиї 30.03.2021 p.

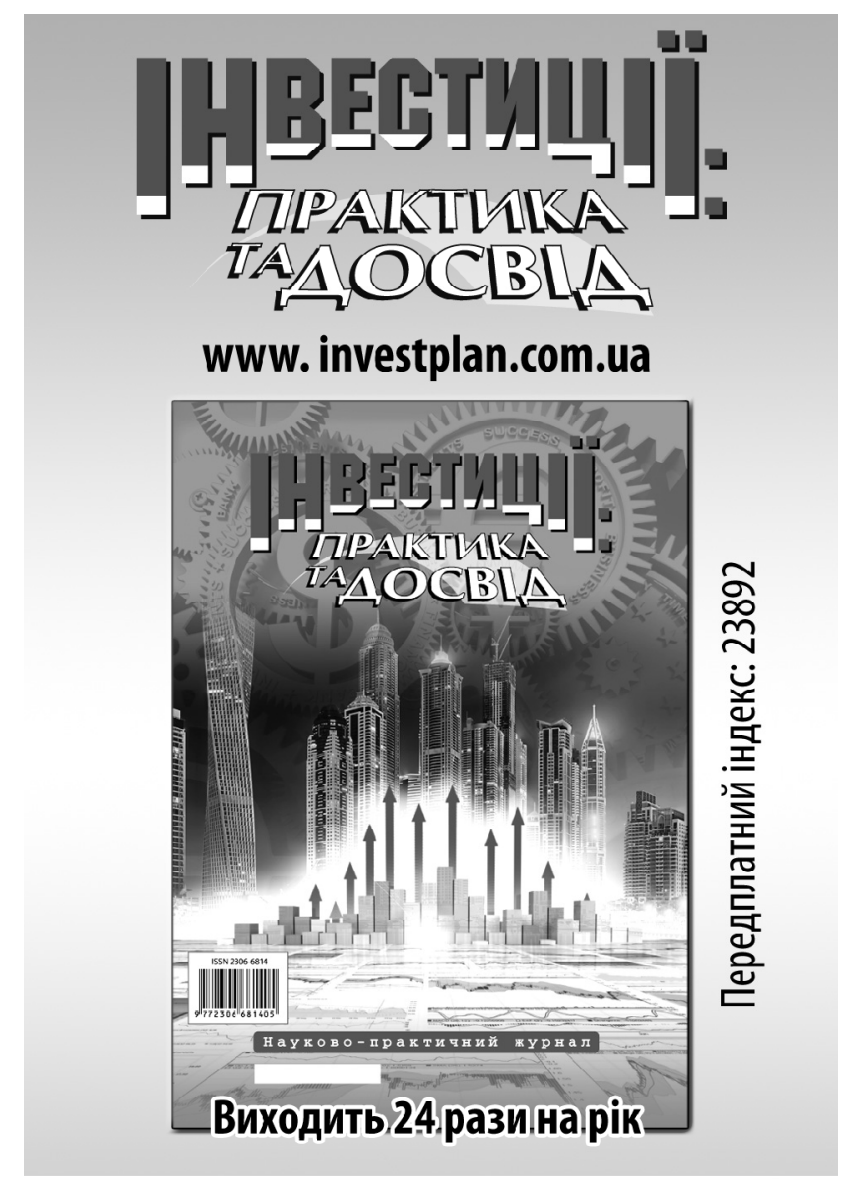

Журнал включено до переліку наукових фрахових видань України (Категорія «Б») 3

ЕКОНОМІЧНИХ НАУК та ДЕРЖАВНОГО УПРАВЛІННЯ

(Наказ Міністерства освіти і науки України № 886 від 02.07.2020)

Спеціальності - 051, 071, 072, 073, 075, 076, 281, 292 
УAK 332.2

\author{
А. М. Третяк, \\ А. е. н., професор, член-кореспондент НААН України, професор кафеАри \\ управління земельними ресурсами та земельного каАастру, \\ Білоцерківський національний аграрний університет \\ ORCID ID: 0000-0002-1154-4797 \\ B. М. Третяк, \\ А. е. н., професор, професор кафедри геодезії та землеустрою, \\ Сумський національний аграрний університет \\ ORCID ID: 0000-0001-6779-1941 \\ A. C. Поліщук, \\ аспірантка, Аержавна екологічна академія післядипломної освіти та управління \\ ORCID ID: 0000-0002-8740-1741
}

DOI: $10.32702 / 2306-6792.2021 .7-8.10$

\title{
ОСОБАИВОСТІ ОЦІНКИ ВАРТОСТІ СІЛЬСЬКОГОСПОААРСЬКОГО ЗЕМЛЕКОРИСТУВАННЯ В ЗЕМЕАЬНІЙ ІПОТЕЦІ
}

\author{
A. Tretiak, \\ Doctor of Economic Sciences, Professor, Chief Researcher, \\ Institute of Agroecology and Nature Management of NAAS of Ukraine \\ V. Tretiak, \\ Doctor of Economic Sciences, Professor, Professor of the Department \\ of Geodesy and Land Management, Sumy National Agrarian University \\ A. Polishchuk, \\ Postgraduate student, State Ecological Academy of Postgraduate Education and Management
}

\section{PECULIARITIES OF ESTIMATING THE COST OF AGRICULTURAL LAND USE IN LAND MORTGAGE}

Визначено негативні і позитивні фактори впливу на сільськогосподарське землекористування як об'єкт заставного креАитування, які обумовлюють особливості оцінки вартості сільськогосподарського землекористування в земельній іпотеці. Виділено основні проблеми розвитку процесу земельного іпотечного кредитування в Україні: оцінка якості землі і вартості сільськогосподарського землекористування пов'язана з деякими труднощами, а єдиної технології оцінки поки не існує; висока ризикованість кредитування під заставу землекористування через невизначеність його ліквідності, яка обумовлена тим, що його продаж за часом триває набагато довше, ніж, наприклаА, продаж квартири чи земельної ділянки, відведеної під малоповерхове будівництво, через нерозвиненість інфраструктури земельного ринку; низькі темпи розробки та вдосконалення земельного законодавства та неузгодженість правових актів; нечіткість землевпорядного процесу та велика кількість адміністративних бар'єрів; високі процентні ставки; непрозорість доходів позичальника; нерозвиненість організаційно-технологічної та фінансової інфраструктури в системі земельної іпотеки.

Визначено, що оцінка заставної вартості сільськогосподарського землекористування виконує функцію індикатора можливості самої іпотечної угоди. Обгрунтовано, що визначення заставної вартості сільськогосподарського землекористування має свій особливий інституціональний процес, який включає чотири напрями визначення показників оцінки, зокрема: 1) диференціація еколого-економічних нормативів сталого (збалансованого) землекористування, складання перспективних $i$ текучих стратегічних планів, аналіз і оцінка існуючого стану використання земель і земельних поліпшень, розроблення проекту землевпорядкування із визначенням періодів реалізації проектних рішень та вартості земельних поліпшень; 2) економічна оцінка землі як засобу виробництва в сільському господарстві, визначення земельної ренти I і II та способів їх вилучення, визначення балансової вартості землекористування і розміру компенсації за вилучення земельних ділянок із сільгоспобороту, визначення величини земельного податку та орендної плати; 3) експертна грошова оцінка заставної вартості землекористування за різними методами із врахуванням земельних поліпшень із подальшим уточненням визначених напрямів земельних поліпшень; 4) оцінка впливу придатності земель на ефективність додаткових вкладень, встановлення відАачі земель на додаткові затрати праці і засобів, визначення напрямів різних видів земельних поліпшень і інвестування.

Negative and positive factors of influence on agricultural land use as an object of mortgage lending, which determine the features of estimation of the value of agricultural land use in the land mortgage are determined. The main problems of development of the process of land mortgage lending in Ukraine are highlighted: the assessment of the quality of land and the cost of agricultural land use is associated with some difficulties, and the single evaluation technology has not yet exist; high risk of lending to land use through the uncertainty of its liquidity, which is due to the fact that its sale is much longer than, for example, the sale of an apartment or land plot allotted under low-rise construction, due to the undevelopment of the infrastructure of the land market; 
low rates of development and improvement of land legislation and inconsistency of legal acts; the fuzziness of the land management process and a large number of administrative barriers; high interest rates; the opacity of the borrower's revenues; underdevelopment of organizational and technological and financial infrastructure in the land mortgage system.

It is determined that the assessment of the mortgage value of agricultural land use serves as an indicator of the possibility of the mortgage agreement.

It is substantiated that the determination of the mortgage value of agricultural land use has its own special institutional process, which includes four directions of determination of evaluation indicators: 1) differentiation of ecological and economic standards of stable (balanced) land use, drawing up promising and fluid strategic plans, analysis and evaluation of the existing state of use of land and land improvements, development of the land management project with the definition of periods of implementation of project decisions and the cost of land improvements; 2) economic assessment of land as a means of production in agriculture, definition of land rent I and II and methods of extracting, determining the carrying amount of land use and the amount of compensation for the removal of land from agriculture, determining the magnitude of land tax and rent; 3 ) expert monetary assessment of the mortgage value of land use by diffrent methods, taking into account land improvements with further improvement, followed by clarification of way of land improvements; 4) an assessment of the impact of land suitability on the effectiveness of additional investments, the establishment of land returns to additional labor costs and means, determining the directions of various types of land improvements and investment.

Ключові слова: земельна іпотека, заставна вартість, експертна грошова очінка, сільськогосподарське землекористуванняб, земельні ресурси.

Key words: land mortgage, mortgage value, expert monetary evaluation, agricultural land use, land resources.

\section{ПОСТАНОВКА ПРОБЛЕМИ}

У світовій практиці іпотечне кредитування під заставу земельних ділянок виникло з появою приватної власності на землю і кредитної справи. Іпотечне кредитування широко використовується в розвинутих країнах. У цих країнах частка кредитів під заставу землі сягає близько $95 \%$ інвестиційних ресурсів фермерів $[1$, c. 125$]$. У країнах з розвинутою ринковою економікою сільським виробникам під заставу землі та нерухомості надають до 40 \% кредитних ресурсів [2], при цьому основну частку кредитів складають середньострокові та довгострокові кредити. На заставлені земельні ділянки накладається заборона, не дозволяється їх продаж до погашення одержаних позик. У випадку несплати в термін земельної позики або відсотків за неї заставлена земля переходить до кредитора.

Зокрема, у сучасній Німеччині іпотечні банки надають позики під заставу земельних ділянок і випускають боргові зобов'язання. Згідно із Законом "Про іпотечні банки" іпотечна позика не може перевищувати $3 / 5$ вартості земельної ділянки, яка заставляється. Кредити надаються на $6,10,15,20$ років за $8-9 \%$ річних [3].

Розвиток іпотечного кредитування $є$ надзвичайно актуальним в Україні. Сьогодні банки практично не надають довгострокові кредити сільськогосподарським виробникам. Водночас у період ринкових реформ у сільському господарстві не поновлювався основний капітал. Отже, іпотечне кредитування потребує державного регулювання, зокрема, визначення заставної ціни земельної ділянки, а також відсоткової ставки за користування іпотечним кредитом. Відсутність на даний момент механізму встановлення ринкової ціни, на основі співвідношення між попитом на землю і її пропозицією, орієнтиром заставної ціни могла б служити стартова ціна земельної ділянки, якою буде експертна грошова оцінка, проведена відповідно до методики, затвердженої Кабінетом Міністрів України від 11 жовтня 2002 року № 1531.

\section{АНАЛІЗ ОСТАННІХ ДОСЛІДЖЕНЬ І ПУБЛІКАЦІЙ}

В останні роки питанню розвитку іпотеки сільськогосподарських земель як форми ринкових операцій із землею приділяється значна увага. Зокрема, у вітчизняній економічній літературі України цю проблему досліджували відомі вчені - П.І. Саблук, В.Я. Месель-Веселяк, І.Р. Михасюк, Є.Й. Майовець, А.М. Третяк, B.М. Трегобчук, А.В. Паламарчук, В.В. Юрчишин. Проте важливі питання ще залишаються невирішеними, зокрема, обгрунтування заставної вартості землекористування в умовах відсутності купівлі-продажу сільськогосподарських земель.

Питання оцінки земельних ділянок, забезпечення ризиків у системі землекористування, іпотечного кредитування досліджуються у працях таких учених: Галушко В. [4], Мартин О. [5], Гнаткович О. [6], Поліщук В. [7; 8], Ступень Р. [9], Шкуратов О. [10].

\section{МЕТА ДОСЛІДЖЕННЯ}

Метою статті є дослідження особливостей оцінки вартості сільськогосподарського землекористування в земельній іпотеці. 


\section{ВИКЛАД ОСНОВНОГО МАТЕРІАЛУ ДОСЛІДЖЕННЯ}

Першими документами в Україні у напрямі запровадження іпотеки землі є Указ Президента України "Про заходи щодо розвитку іпотечного ринку в Україні" від 8.08.2002 р. № 655, а також "Концепція створення національної системи іпотечного кредитування", у яких визначено основні напрями формування іпотечного ринку. В Україні іпотека земель частково унормована Законом України "Про заставу", відповідно до якого предметом іпотеки можуть бути приватизовані земельні ділянки та багаторічні насадження громадян [11]. Іпотечний кредит під земельні ділянки, що належать на праві власності не тільки окремим громадянам, але і юридичним особам передбачає Земельний кодекс України [12], а також Закон України "Про іпотеку" [13].

Отже, розвиток іпотеки на земельному ринку в Україні передбачає створення правових й інституціональних передумов, зокрема, створення правового поля розвитку інфраструктури ринку земельних ділянок (складовою якої інституція оцінки заставної вартості) і заснування відповідних фінансових установ (державного Земельного (іпотечного) банку).

В якості окремого напряму земельно-іпотечне кредитування має досить важливу економічну роль: по-перше, як вже було зазначено, це можливість створювати і залучати додаткові кошти в сферу підтримки та розвитку матеріального виробництва; по-друге, даний вид кредитування допомагає забезпечувати як оборот, так і перерозподіл земельних ділянок між власниками, в цьому випадку це означає можливість переходу земельних ділянок власників земельних часток (паїв) у руки ефективних власників, виключаючи нераціональне їх використання; по-третє, існування земельно-іпотечного кредитування стає підставою виникнення інститутів вторинного земельного ринку для функціонування власної інфраструктури [14].

Важливу роль у формуванні інституціонального середовища земельної іпотеки відіграють земельно-оціночні роботи, які відповідно до статті 38 Закону України "Про землеустрій" [15], виконуються з метою визначення якісних характеристик, економічної цінності та вартості земель. Відповідно до закону України "Про оцінку земель" [16] експертна грошова оцінка передбачає визначення ринкової (імовірної ціни продажу на ринку) або іншого виду вартості об'єкта оцінки (заставна, страхова, для бухгалтерського обліку тощо), за яку він може бути проданий (придбаний) або іншим чином відчужений на дату оцінки відповідно до умов угоди. Відповідно до Методики експертної грошової оцінки земельних ділянок [17] вона здійснюється на основі таких методичних підходів: капіталізація чистого операційного або рентного доходу (пряма і непряма); зіставлення цін продажу подібних земельних ділянок; урахування витрат на земельні поліпшення.

Земельне іпотечне кредитування як фінансовий інструмент в сільському господарстві має у своїй основі використання в якості застави досить специфічний об'єкт - землекористування як аграрна нерухомість. Тут потрібно брати до уваги і особливості ведення самого сільського господарства, успішність якого $€$ важливою частиною забезпечення повернення виданого банком кредиту. В якості специфічних факторів галузі можна назвати:

- сезонність і циклічність робіт;

- вплив природно-економічних і погодних умов;

- нерівномірність обсягів реалізації продукції;

- нерівномірність надходження виручки;

- не регульований обіг земельних ділянок власників земельних часток (паїв) у межах сільськогосподарського землекористування як об'єкту аграрної нерухомості.

3 огляду на вищезазначене, необхідно розуміти, що всі ці фактори прямо впливають на вартість самого землекористування, здатної виступити в якості застави.

Факторами, які свідчать на користь використання землекористування як застави:

- незмінне місце розташування;

- зростаюча в часі вартість;

- можливість бути джерелом доходу при використанні;

- збереження права власності заставодавцем (тобто за власником залишається право володіння і право користування: дві складові 3 тріади права власності);

- землеустрій та землевпорядкування як інструмент регулювання обігу земельних ділянок власників земельних часток (паїв) у межах сільськогосподарського землекористування як об'єкту аграрної нерухомості.

Саме ці переваги дозволяють багатьом економістам [18; 19]) говорити про те, що в порівнянні з іншими видами нерухомості іпотека земелі є найбільш надійним і реальним забезпеченням повернення кредиту (рис. 1).

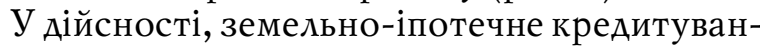
ня як інструмент залучення інвестицій широко використовується в більшості розвинених ринкових країн. Наприклад, в структурі аграрно- 
го капіталу розвинених західноєвропейських країн, як-от: Англія, Німеччина, Франція, Швеція, частка фінансування сільськогосподарських товаровиробників за рахунок позикових коштів, де заставним об'єктом виступає власність на землю, становить близько $50 \%$ [18]. У США ця частка досягає 70\% від величини сукупних витрат на виробництво сільськогосподарської продукцї̈. Так можна простежити очевидну закономірність: чим більше підприємство, тим більше частка кредитних коштів в їі основному капіталі. Це означає, що отримуються позики гарантуються величезною земельною площею, а наявність такої площі дозволяє розраховувати на значні кредитні суми, які в рази більше тих, що можуть бути виділені фермерам та дрібним і середнім фірмам за програмами земельного іпотечного кредитування. Економічна практика землекористування розвинених країн підтверджує цю тезу. Наприклад, у Голландії можна розраховувати на отримання довгострокового кредиту (тривалість $30-50$ років) під заставу землекористування з розташованими на ньому об'єктами нерухомого майна (фермерський будинок, сільськогосподарські споруди, ферми і т. п.). I розмір кредитних коштів може становити $60-80 \%$ від оціночної вартості предметів іпотеки [14].

Загалом земельна іпотека дозволяє сільськогосподарським виробникам розвинених країн, з одного боку, розширювати сільгосптоваровиробництво шляхом використання основних фондів, придбаних за рахунок іпотечних кредитів, а 3 іншого - прискорювати оборот капіталу і отримувати додатковий прибуток.

Водночас оцінка землекористування як можливого заставного активу починається задовго до того, як у справу вступають оцінювачі, покликані встановити справжню заставну вартість конкретного землекористування для цілей подальшого кредитування. Всі позитивні і негативні фактори проводять чітку лінію вододілу між землею як сферою сільського господарства і землею як об'єктом для житлового будівництва.

Перша група, землекористування обтяжене негативними факторами цільового використання земель, у банках стає швидше неліквідним активом.

\section{Незмінне місце розташування}

Зростаюча в часі вартість

Можливість бути джерелом доходу при використанні

Збереження права власності на земельну ділянку заставодавцем

Землеустрій як інструмент регулювання обігу земельних ділянок власників земельних часток (паїв)

Рис. 1. Логічно-змістовна схема впливу на когосподарське землекористування як об'єкт редитування негативних і позитивних факторів

Аруга група іпотечних кредитів видається набагато охочіше, тому що цільове призначення землекористування інше і реальна можливість реалізації, за неможливості витребувати кредитний борг, набагато вище. Ао того ж і оцінка земельних ділянок під забудовою вже знайшла свою повсякденну практику, методи і специфіку, що дозволяє видавати об'єктивний оціночний варіант вартості, необхідність врахування категорій земельного фонду для цілей ï̈ оцінки відображено в науковій літературі.

Необхідність оцінки землі виникає на попередньому етапі роботи в рамках укладення кредитного іпотечного договору. Роль оцінки землі важлива на самому початку укладання договору, і полягає вона в тому, що:

- по-перше, необхідно оцінити конкретне землекористування як об'єкт аграрної нерухомості на предмет можливості бути запорукою в кредитній угоді (безумовно, будь-яке землекористування має вартість, але це не тотожна наявності інвестиційнӧ̈, а отже, і кредитного потенціалу);

- по-друге, необхідно назвати конкретну заставну вартість, від якої буде залежати і відсоток кредитних коштів (можна розраховувати на $80 \%$ чи 50\% від вартості землекористування) і точна сума кредиту.

Перша умова - це гарантія (хоч і не стовідсоткова) банку, що видані позикові кошти будуть повернуті. Аруга умова - це гарантія позичальника на отримання гідної суми креди- 


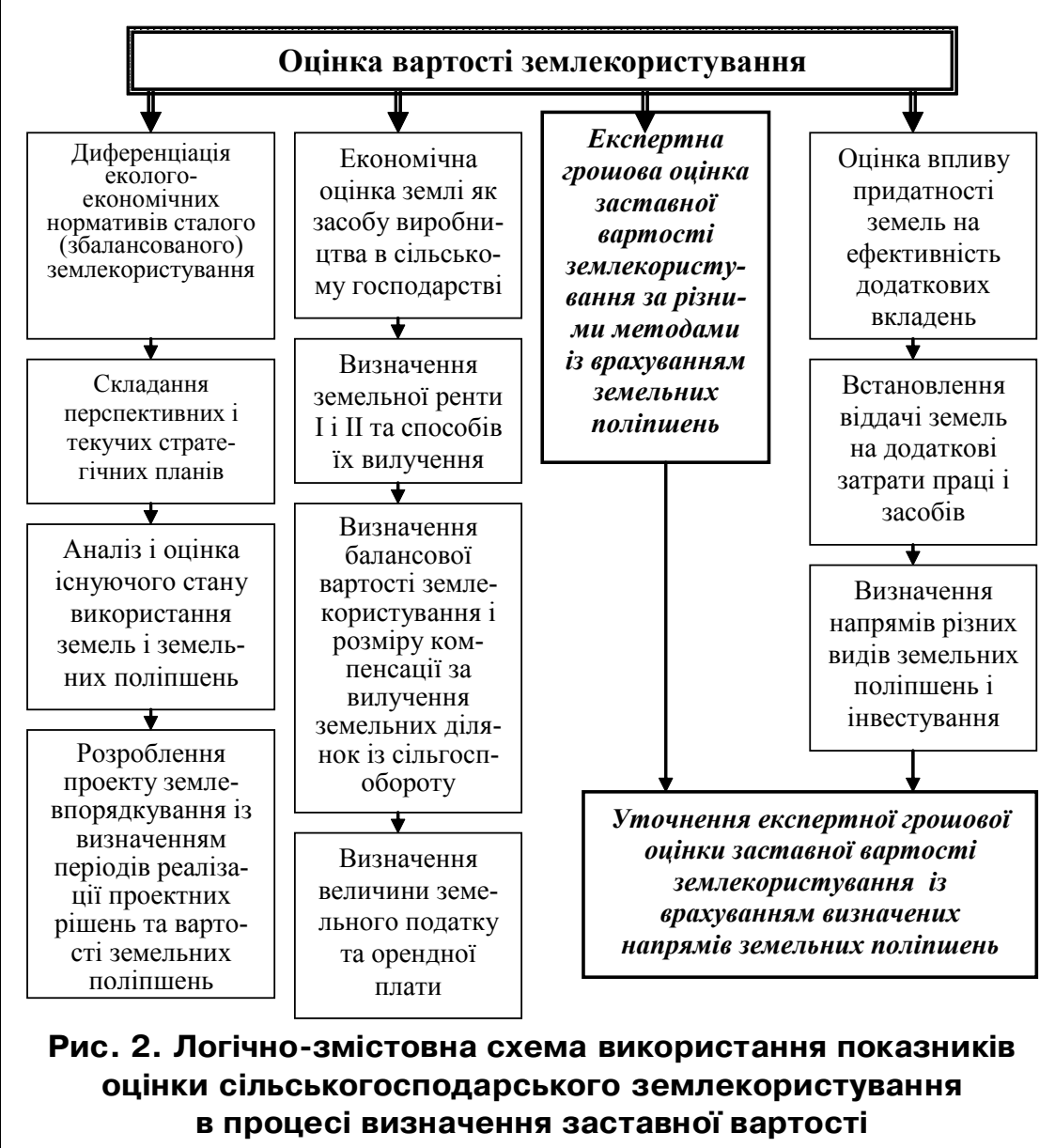

важливо надати всі необхідні документи для забезпечення об'єктивності остаточних висновків, цифра 3 яких ляже в основу кредитного договору, або за результатами яких підписання кредитного договору не відбудеться. Наприклад, наявність наданого банку проекту землеустрою організації земельних угідь та впорядкування сівозмін і бізнес-плану дозводить компанії-оцінювача досить точно визначити факт цільового та ефективного використання земель. А наявність сертифікатів та експертних висновків щодо складу та придатності грунтів дозволить упевнитися в тому, що землекористування відповідає нормам екологічності вирощування сільськогосподарської продукції, так само як і реалізовувати її при дотриманні технології вирощування.

У цьому зв'язку, нами пропонується логічно-змістовна схема використання показників оцінки сільськогосподарського землекористування в процесі визначення заставної вартості (рис. 2).

Важливими умовами оцінки заставної вартості землекористування $€$ правильність і обгрунтованість вибору критеріїв оцінки. В основу оцінки заставної вартості землекористування повинні бути покладені об'єктивні критерії, що характеризують якість земель та земельні поліпшення. Наприклад, якість землі як засіб сільськогосподарського виробництва можна охарактеризувати шляхом встановлення рівня родючості і місця розташування, що характеризується земельною рентою І. Оцінювати необхідно обидва чинники, але якщо один 3 них обрано основою оцінки, то другий повинен бути відображений в оціночному звіті у вигляді відповідного поправочного коефіцієнта [20]. Отже, на попередньому етапі кредитної угоди центральне місце в механізмі земельного кредитування належить безпосередньо оцінці кількісних, якісних та агро-еколого-технологічних параметрів предмета застави - землі.

Оцінка заставної вартості сільськогосподарського землекористування - це визначення ринкової вартості землекористування сформованого на праві власності на землю, або заставної вартості землекористування сформованого на праві оренди землі. Оцінка заставної вартості землекористування сформованого на 
праві оренди землі суттєво відрізняється від оцінки вартості землекористування, що сформоване на праві власності на землю. І в цьому зв'язку оцінювачу необхідна інформація про величину земельної ренти I і II. Адже заставна вартість землекористування сформованого на праві оренди землі буде визначатися за величиною земельної ренти II.

Оцінка заставної вартості сільськогосподарського землекористування - це визначення ринкової вартості землекористування сформованого на праві власності на землю, або заставної вартості землекористування сформованого на праві оренди землі. Оцінка заставної вартості землекористування сформованого на праві оренди землі суттєво відрізняється від оцінки вартості землекористування, що сформоване на праві власності на землю. I в цьому зв'язку оцінювачу необхідна інформація про величину земельної ренти I і II. Адже заставна вартість землекористування сформованого на праві оренди землі буде визначатися за величиною земельної ренти II.

Водночас необхідно розуміти, що ринкову вартість має лише те землекористування, яке здатне задовольняти потреби користувача протягом певного періоду часу. Земельною іпотекою називається система довгострокових кредитів, де земля використовується в якості застави для забезпечення зобов'язань перед кредитором, з метою отримання грошової позики. За такої форми застави закладається землекористування, що залишається у власності боржника, а кредитор у разі невиконання останнім свого зобов'язання набуває право отримання боргу за рахунок реалізації цього майна [20]. Таким чином, якщо розглядати земельну іпотеку з точки зору розподілу доходу, створеного в сільському господарстві, вона означає продаж всієї земельної ренти або їі частини у вигляді процентів за іпотечним кредитом, якщо землекористування є об'єктом власності боржника, або продаж тільки земельної ренти II, якщо землекористування сформоване на правах оренди землі. Як для банку, так і для позичальника оцінка вартості застави має першорядне значення. Банк встановлює можливість видати кредит, визначає верхню межу кредитування і виявляє достатність джерел для погашення кредиту. А позичальник насправді бачить суму, на яку зможе розраховувати при кредитуванні. Отже, оцінка заставної вартості землекористування виконує функцію індикатора можливості самої угоди.

Таким чином, можна виділити такі проблеми розвитку процесу земельного іпотечного кредитування в Україні:
- оцінка якості землі і вартості сільськогосподарського землекористування пов'язана з деякими труднощами, а єдиної технології оцінки поки не існує;

- висока ризикованість кредитування під заставу землекористування через невизначеність його ліквідності, яка обумовлена тим, що його продаж за часом триває набагато довше, ніж, наприклад, продаж квартири чи земельної ділянки, відведеної під малоповерхове будівництво, через нерозвиненість інфраструктури земельного ринку;

- низькі темпи розробки та вдосконалення земельного законодавства та неузгодженість правових актів;

- не чіткість землевпорядного процесу та велика кількість адміністративних бар'єрів;

- високі процентні ставки;

- непрозорість доходів позичальника;

- нерозвиненість організаційно-технологічної та фінансової інфраструктури в системі земельної іпотеки.

Аля вирішення першої проблеми доцільно забезпечення взаємозв'язку економічної та експертної оцінки предметів іпотеки, здійснення науково обгрунтованої типологізації сільськогосподарського землекористування на основі вироблення раціональних критеріальних підходів та удосконалення методів оцінки вартості земельних ділянок. Що стосується ризиків, то для їх зниження потрібно формування моделей процентних ставок, моделей кредитних договорів з розширеним розподілом позитивних і негативних умов кредитування і прогнозу грошових потоків, створення методик управління ризиками при кредитуванні. Також слід здійснювати моніторинг як природно-виробничого потенціалу господарства, так і фінансового стану позичальника. Аля прискорення процесу земельно-іпотечного кредитування важливу роль буде відігравати держава і певні заходи державної підтримки, спрямовані на створення стійкої в довгостроковій перспективі кредитнофінансової інфраструктури земельно-іпотечного кредитування. Попри досить довгий перелік перешкод, земельне іпотечне кредитування досить перспективний інструмент інвестування в сільське господарство країни.

\section{ВИСНОВКИ І ПЕРСПЕКТИВИ ПОДАЛЬШИХ РОЗВІДОК}

Визначено, що оцінка заставної вартості сільськогосподарського землекористування виконує функцію індикатора можливості самої іпотечної угоди. Визначення заставної вартості сільськогосподарського землекористування 
має свій особливий інституціональний процес, який включає чотири напрями визначення показників оцінки, зокрема:

1) диференціація еколого-економічних нормативів сталого (збалансованого) землекористування, складання перспективних і текучих стратегічних планів, аналіз і оцінка існуючого стану використання земель і земельних поліпшень, розроблення проекту землевпорядкування із визначенням періодів реалізації проектних рішень та вартості земельних поліпшень;

2) економічна оцінка землі як засобу виробництва в сільському господарстві, визначення земельної ренти I і II та способів їх вилучення, визначення балансової вартості землекористування і розміру компенсації за вилучення земельних ділянок із сільгоспобороту, визначення величини земельного податку та орендної плати;

3) експертна грошова оцінка заставної вартості землекористування за різними методами із врахуванням земельних поліпшень із послідуючим уточнення із врахуванням визначених напрямів земельних поліпшень;

4) оцінка впливу придатності земель на ефективність додаткових вкладень, встановлення віддачі земель на додаткові затрати праці і засобів, визначення напрямів різних видів земельних поліпшень і інвестування.

\section{$\Lambda$ ітература:}

1. Смолінська С.А. Організаційно-економічні передумови запровадження іпотеки сільськогосподарських земель в Україні // Економіка АПК. - 2006. - № 2. - С. 125.

2. Михасюк I., Майовець Є. Аграрний сектор АПК: Проблеми і шляхи вирішення. Аьвів: Вид. центр $\Lambda$ НУ ім. Івана Франка, 2001. - C. 135 .

3. Паламарчук $\Lambda . В$. Аеякі аспекти організації іпотеки землі за кордоном // Землевпорядкування. - 2003. - № 1. - С. 54-57.

4. Галушко В.П.Економічна оцінка та методичні підходи до оптимізації ціни землі в умовах ринкової економіки. Вісник Академії праці і соціальних відносин Федерації профспілок України. 2015. № 1-2. С. 55-58.

5. Мартин О.М. Розвиток ринку сільськогосподарських земель та іпотечне кредитування. Наукові записки [Національного університету "Острозька академія"]. Сер.: Економіка. 2010. Вип. 14. С. 383-390.

6. Гнаткович O.А. Забезпечення здійснення іпотечних земельних операцій сільськогосподарськими підприємствами. Ефективна економіка. 2014. № 1. URL: http://nbuv.gov.ua/UJRN/ efek_2014_1_3
7. Поліщук В.Г. Особливості сучасної просторової і змістовної бази сільськогосподарського землекористування в системі земельноіпотечного кредитування. Актуальні проблеми економіки. 2015. № 3. С. 219-226.

8. Поліщук В.Г. Модель інституційної основи земельно-іпотечного кредитування в Україні під заставу землеволодінь сільськогосподарських підприємств сформованих переважно на правах оренди землі. Землеустрій, кадастр і моніторинг земель. 2014. № 3-4. С. 49-55.

9. Ступень Р. Розвиток земельно-іпотечного кредитування сільського господарства через механізм земельних банків. Економіст. 2014. № 4. C. $31-34$.

10. Шкуратов О. Роль земельної іпотеки в кредитуванні сільськогосподарських товаровиробників. Економіст. 2011. № 10. С. 12-13.

11. Закон України від 2.10.1992 р. № 2654ХП "Про заставу" // Відомості Верховної Ради. - 1992. — № 47. - С. 642.

12. Земельний кодекс України: Закон України від 25.10.2001 № 2768-III. URL: https:// zakon.rada.gov.ua/ laws/show/2768-14

13. Про іпотеку: Закон України від 05.06.2003 № 898-IV. URL: https://zakon.rada.gov.ua/laws/show/898-15

14. Воропаев А.И. Земельно-ипотечное кредитование сельского хозяйства / А.И. Воропаев, А.Н. Петрова // Вестник Орловского государственного аграрного университета. 2010. - № 4. - Т. 24. - С. 54-58 [Электронный ресурс]. - Режим доступа: https:// cyberleninka.ru/article/n/zemelno-ipotechnoekreditovanie-selskogo-hozyaystva/viewer

15. Про землеустрій: Закон України від 22.05.2003 № 858-IV. URL: https://zakon.rada.gov.ua/laws/show/ 858-15

16. Про оцінку земель: Закон України від 11.12.2003 № 1378-IV. URL: https://zakon.rada.gov.ua/laws/show/ 1378-15

17. Про експертну грошову оцінку земельних ділянок: Постанова Кабінету Міністрів України від 11.10.2002 № 1531. URL: https://zakon.rada.gov.ua/laws/ show /1531- 2002-\% D0\%BF?f ind $=1 \&$ text $=\% \mathrm{~F} 1 \%-\mathrm{B} 3 \% \mathrm{~EB} \% \mathrm{FC} \# \mathrm{w} 14$

18. Ганжа С.В. Механизм ипотечного кредитования под залог земель сельскохозяйственного назначения: классический подход и региональный опыт современной России / С.В. Ганжа, Е.И. Роговский, Н.С. Ганжа // Известия Алтайского государственного университета. - 2012. - № 2-1. - С. 261-269 [Электронный ресурс]. - Режим доступа: http:// cyberleninka.ru/article/n/mehanizm-ipotechnogo-kreditovaniya-pod-zalog-zemel- 
selskohozyaystvennogo-naznacheniya-klassicheskiy-podhod-i-regionalnyy-opyt\#ixzz3Rm114xQR

19. Аругак В.М.,Поліщук В.Г. Економічна сутність земельної іпотеки на засадах ринку права оренди землі / В.М.Аругак, В.Г. Поліщук // Землеустрій, кадастр і моніторинг земель. 2014. — № 1-2. - С. 31-39.

20. Чередникова А.О. Формирование и развитие земельно-ипотечного кредитования в сельском хозяйстве / А.О. Чередникова [Электронный ресурс]: автореферат к диссертации на соискание ученой степени доктора экономических наук, 13.08.2013 г. - Режим доступа: http:// vak2.ed.gov.ru

\section{References:}

1. Smolins'ka, S.D. (2006), "Organizational and economic prerequisites for the introduction of mortgages of agricultural land in Ukraine", Ekonomika APK, vol. 2, pp.125.

2. Mykhasiuk, I. and Majovets,' Ye. (2001), Ahrarnyj sektor APK: Problemy i shliakhy vyrishennia [Agricultural sector of agro-industrial complex: Problems and ways of the decision], Ttsentr LNU im. Ivana Franka, Lviv, Ukraine.

3. Palamarchuk, L.V. (2003), "Some aspects of the organization of land mortgages abroad", Zemlevporiadkuvannia, vol. 1, pp. 54-57.

4. Halushko, V.P. (2015), "Economic evaluation and methodological approaches to optimizing the price of land in a market economy", Visnyk Akademii pratsi i sotsial'nykh vidnosyn Federatsii profspilok Ukrainy, vol. 1-2, pp. 55-58.

5. Martyn, O.M. (2010), "Agricultural land market development and mortgage lending", Scientific notes National University "Ostroh Academy", Ekonomika, vol. 14, pp. 383-390.

6. Hnatkovych, O.D. (2014), "Ensuring the implementation of mortgage land transactions by agricultural enterprises", Efektyvna ekonomika, vol. 1, available at: http://nbuv.gov.ua/UJRN/ efek_2014_1_3 (Accessed 26 Mar 2021).

7. Polishchuk, V.G. (2013) "Features of modern spatial and substantive base of agricultural land use in the system of land mortgage lending", Aktual'ni problemy ekonomiky, vol. 3, pp. 219-226.

8. Polishchuk, V.G. (2014), "Model of the institutional basis of land mortgage lending in Ukraine secured by land holdings of agricultural enterprises formed mainly on land lease rights", Zemleustrij, kadastr i monitorynh zemel, vol. 3-4, pp. 49-55.

9. Stupen, R. (2014), "Development of land mortgage lending to agriculture through the mechanism of land banks", Ekonomist, vol. 4, pp. $31-34$.
10. Shkuratov, O. (2011), "The role of land mortgages in lending to agricultural producers", Ekonomist, vol. 10, pp. 12-13.

11. The Verkhovna Rada of Ukraine (1992), The Law of Ukraine "On gage", Vidomosti Verkhovnoi Rady, vol. 47, p. 642.

12. The Verkhovna Rada of Ukraine (2001), "The Land Code of Ukraine", available at: https:/ /zakon.rada.gov.ua/laws/show/2768-14 (Accessed 26 Mar 2021).

13. The Verkhovna Rada of Ukraine (2003), The Law of Ukraine "On mortgage", available at: https://zakon.rada.gov.ua/laws/show/898-15 (Accessed 25 Mar 2021).

14. Voropaev, A.I. and Petrova, A.N. (2010) "Land and mortgage lending for agriculture", Vestnik Orlovskogo gosudarstvennogo agrarnogo universiteta, vol. 3, available at: https://cyberleninka.ru/article/n/zemelno-ipotechnoekreditovanie-selskogo-hozyaystva/viewer (Accessed 25 Mar 2021).

15. The Verkhovna Rada of Ukraine (2003), The Law of Ukraine "On land management", available at: https://zakon.rada.gov.ua/laws/show/858-15 (Accessed 26 Mar 2021).

16. The Verkhovna Rada of Ukraine (2003), The Law of Ukraine "On land valuation", available at: https://zakon.rada.gov.ua/laws/show/1378-15 (Accessed 26 Mar 2021).

17. Cabinet of Ministers of Ukraine (2002), Resolution "On expert monetary evaluation of land sections"', available at: https://zakon.rada.gov.ua/ laws/show/1531-2002-\%D0\%BF?find =1\&text $=\% \mathrm{~F} 1 \%-\mathrm{B} 3 \% \mathrm{~EB} \% \mathrm{FC} \# \mathrm{w} 14$ (Accessed $26 \mathrm{Mar}$ 2021).

18. Ganzha, S.V. Rogovskij, E.I and Ganzha, N.S. (2012), "Mechanism of mortgage lending secured by agricultural land: a classic approach and regional experience of modern Russia", Izvestija Altajskogo gosudarstvennogo universiteta, vol. 2-1, available at: http://cyberleninka.ru/article/n/mehanizm-ipotechnogokreditovaniya-pod-zalog-zemelselskohozyaystvennogo-naznacheniya-klassicheskiy-podhod-i-regionalnyy-opyt\#ixzz3Rm114xQR (Accessed 25 Mar 2021).

19. Druhak, V.M. and Polischuk, V.H. "The economic day of the land lease at the ambush rinku land lease rights", Zemleustrij, kadastr i monitorynh zemel, vol. $1-2$, pp. 31-39.

20. Cherednikova, A.O. (2013), "Formation and development of land and mortgage lending in agriculture", Abstract of Ph.D. dissertation, Economy, available at: http://vak2.ed.gov.ru (Accessed 24 Mar 2021).

Стаття надійшла до редакиії 26.03.2021 p. 
УAK 338.27

B. Я. Нусінов,

А. е. н., професор, професор кафедри обліку, оподаткування,

публічного управління та адміністрування, Криворізький національний університет

ORCID ID: 0000-0002-9293-2969

$\Lambda$. А. Буркова,

к. е. н., Аоцент, доцент кафеАри обліку, оподаткування,

публічного управління та адміністрування, Криворізький національний університет

ORCID ID: 0000-0002-2840-5785

DOI: $10.32702 / 2306-6792.2021 .7-8.18$

\title{
ОЦІНЮВАННЯ ЙМОВІРНОСТІ НАСТАННЯ БАНКРУТСТВА ПІАПРИЕМСТВ 3 УРАХУВАННЯМ ГОРИЗОНТУ ПРОГНОЗУВАННЯ
}

\author{
V. Nusinov, \\ Doctor of Economic Sciences, Professor, Professor of the Department of Accounting, \\ Taxation, Public Governance and Administration, Kryvyi Rih National University \\ L. Burkova, \\ $\mathrm{PhD}$ in Economics, Associate Professor, Associate Professor of the Department of Accounting, \\ Taxation, Public Governance and Administration, Kryvyi Rih National University
}

\section{ASSESSING THE PROBABILITY OF BANKRUPTCY OF ENTERPRISES TAKING INTO ACCOUNT THE FORECAST HORIZON}

Акцентується увага на тому, що існуючі на сьогодні методичні підходи до оцінювання ймовірності настання банкрутства підприємств не дозводяють установити наближення цієї події в часовому аспекті, а лише вказують на ймовірність їі настання в поточному періоді або найближчим часом, однак не передбачають, наскільки швидко ця подія може відбутися. Водночас у більшості випадків саме від часових обмежень повністю залежить вибір термінових заходів щодо виправлення фінансового стану підприємства, завчасне проведення яких Аозволить відтермінувати ймовірність настання банкрутства підприємства. Запропоновано методичний підхіА, який дозволить оцінювати ймовірність настання банкрутства підприємства залежно від тривалості мождивого часу проведення цієї процеАури.

Since independence, Ukraine has gone through several stages of the crisis. Unfortunately, the global crisis caused by the COVID-19 outbreak is currently in an active phase, and its complication in our country has occurred due to the stratification of the unstable economic and political situation. As a result, the share of unprofitable enterprises in Ukraine is growing rapidly, which is increasingly accompanied by the opening of bankruptcy proceedings and even liquidation. We believe that bankruptcy is not an unlikely, unpredictable, unexpected event, the possibility of its occurrence can be predicted, predicted, experienced and eliminate the possible consequences. However, the current models for estimating the probability of bankruptcy are not suitable for use, as noted by modern researchers. In addition, the existing models are outdated, do not take into account modern features of economic development. Therefore, taking into account the statistical data of Ukrainian enterprises, both the key indicators used in well-known models and the weighting factors set for them need to be revised. Thus, there is a question of determining indicators that can predict the development of events in the early stages of bankruptcy of domestic enterprises. In addition, none of the existing methodological approaches allows to establish the approximation of the probability of bankruptcy of enterprises, taking into account the forecast horizon. At the same time, in most cases, the choice of urgent measures to correct the financial condition of the enterprise depends entirely on time constraints, the early implementation of which will delay the onset of bankruptcy of the enterprise. 
Therefore, the purpose of the study is to develop a methodological approach that will assess the probability of bankruptcy of enterprises taking into account the forecast horizon.

Within the framework of this study, 3 years were chosen as the estimated period, which corresponds to three stages of the forecasting horizon: short-term, medium-term and long-term. An appropriate model for estimating the probability of bankruptcy is developed for each stage of the forecasting horizon. An appropriate scale has been developed to interpret the obtained values of the integrated indicator for assessing the probability of bankruptcy of enterprises, taking into account the forecasting horizon.

The results of the approbation confirm the correctness of the developed models of estimating the probability of bankruptcy of enterprises taking into account the forecasting horizon and the expediency of their application.

Ключові слова: банкрутство, ймовірність, горизонт прогнозування, модель, дискримінантний аналіз, діагностика.

Key words: bankruptcy, probability, forecast borizon, model, discriminant analysis, diagnosis.

\section{ПОСТАНОВКА ПРОБЛЕМИ}

3 часів незалежності Україна пережила вже декілька етапів кризи. На жаль, нині в активній фазі перебуває світова глобальна криза, що викликана спалахом COVID-19, а їі ускладнення в нашій державі відбулось внаслідок нашарування на нестабільну економічну та політичну ситуації. Внаслідок цього в Україні великими темпами зростає частка збиткових підприємств, що дедалі більше супроводжується відкриттям процедури їнього банкрутства i навіть ліквідацією. Сучасними науковцями наводяться рекомендації для удосконалення моделей оцінки ймовірності настання банкрутства підприємств. Однак й дотепер не досліджено питання відносно оцінювання ймовірності настання банкрутства підприємств з урахуванням горизонту прогнозування. Звісно, що цей інцидент може статися як у поточному році, так i через невизначений проміжок часу. Водночас для підприємства та його стейкхолдерів важливим є момент часу, коли це може статися, адже впливає на прийняття відповідних управлінських рішень.

\section{АНАЛІЗ ОСТАННІХ ДОСЛІДЖЕНЬ ТА ПУБЛІКАЦІЙ}

Варто зазначити, що до процедури банкрутства можуть потрапити будь-які підприємства, незалежно від їх розміру, форм власності, сфер господарювання тощо. Так, наприклад, у роботі [8] слушно зауважено, що навіть гігантські корпорації, які на перший погляд здаються абсолютно невразливими, можуть розпастися під впливом невдалого збігу обставин.

Концепція банкрутства є багатоаспектною, адже використовується у різноманітних суспільно-політичних і природничих науках, що викликає дискусії серед науковців відносно сутності цього поняття, причин його виникнення, можливих наслідків, способів оцінювання тощо. Аалі у роботі розглянемо детальніше сутність поняття "банкрутство", що утворилося від двох італійських слів: "banco" - "лавка" та "rotto" - "зламаний" (за легендою, якщо торговець не міг сплатити борги, то італійські стражники ламали його крамницю).

Результати проведеного огляду літературних джерел щодо сутності поняття "банкрутство" узагальнено у таблиці 1 .

Настає тоді, коли підприємство не спроможне сплачувати свої рахунки або його зобов'язання перевищують ринкову ціну активів.

Аослідники банкрутство здебільшого ідентифікують 3 фінансовою неспроможністю підприємства задовольнити у встановлені строки вимоги перед кредиторами чи зобов'язання перед бюджетом, що визнано у судовому порядку.

3 приводу видів банкрутства автори робіт 1; 7 справедливо зазначають, що воно може бути реальним, технічним, умисним або фіктивним.

Р. Фарсон висловив думку відносно того, що банкрутство може бути потенційно корисним лихом, адже зміна власників підприємства може бути позитивною, а ті підприємства, які внаслідок банкрутства не припинили свого існування, а зуміли залишитися на плаву, в результаті становляться більш сильнішими та знаходять здатність концентруватися на найбільш важливих завданнях [8]. Тобто автором роботи [8] не виключається можливість позитивних змін внаслідок банкрутства підприємства.

Як здається, підхід до визначення банкрутства в якості потенційно корисного лиха є не- 
достатньо коректним. Якщо підприємство визнається банкрутом, то передбачається погашення боргів перед його кредиторами за встановленою черговістю, у зв'язку з чим усе майно підприємства підлягає продажу. Водночас зміна власників підприємства може відбутися у таких випадках:

1) якщо підприємство було ліквідовано, але тоді це буде вже інше підприємство;

2) якщо відбулось фіктивне банкрутство, але зміна власників підприємства при цьому відбувається лише формально.

Якщо ж підприємство умисно доведено до банкрутства (внаслідок діяльності або бездіяльності власників), то це взагалі $є$ неправомірними діями, спрямованими на завдання шкоди кредиторам, але само підприємство від цього не становиться кращим.

Відносно значення інституту банкрутства у роботі 4 наголошується на двох аспектах:

1) у разі ліквідації з обороту виключаються неплатоспроможні суб'єкти господарювання, що сприяє оздоровленню ринку;

2) підприємства, що опинилися в стані неплатоспроможності, мають можливість реорганізувати свою діяльність та досягти фінансової стабільності, що дозволить їм відновити свій статус.

Вважаємо, що банкрутство не є малоймовірною, непередбачуваною, неочікуваною подією, можливість його настання можна передбачати, прогнозувати, пережити та усунити можливі наслідки.

Відносно настання процедури банкрутства підприємства, то вона може розпочатися або ні. Якщо процедура банкрутства розпочалась, то це супроводжується юридичними змінами на підприємстві. На цьому етапі важливо не допустити перехід підприємства до наступної стадії у процедурі банкрутства, а тим більш - до його ліквідації. Якщо ж процедура банкрутства не розпочалась, то варто оцінювати ймовірність настання цієї події.

Питанням оцінки ймовірності настання банкрутства підприємств присвячена досить велика кількість наукових праць зарубіжних та вітчизняних вчених, серед яких найбільш відомими є моделі Е. Альтмана, Р. Міса, У. Бівера, Р. Таффлера, А. Фулмера, Г. Спрінгейта, І. Бланка, О. Зайцевої, А. Ковальова, Г. Савицької, Р. Сайфулліна, О. Терещенко, А. Шеремета тощо. Кількість збанкрутілих підприємств дедалі збільшується, а наявні моделі оцінювання ймовірності настання банкрутства українських підприємств 3 метою своєчасного попередження можливості настання цієї події мають певні
Таблиця 1. Підходи до визначення сутності поняття "банкрутство"

\begin{tabular}{|c|c|}
\hline Автори & Тлумачення терміну \\
\hline $\begin{array}{l}\text { Кодекс України } 3 \\
\text { процедур } \\
\text { банкрутства [3] }\end{array}$ & $\begin{array}{l}\text { Визнана господарським судом неспроможність } \\
\text { боржника відновити свою платоспроможність за } \\
\text { допомогою процедури санації та реструктуризації } \\
\text { і погасити встановлені у порядку, визначеному } \\
\text { Кодексом, грошові вимоги кредиторів інакше, ніж } \\
\text { через застосування ліквідаційної процедури }\end{array}$ \\
\hline $\begin{array}{l}\text { Р. Брейли, } \\
\text { С. Майерс [2] }\end{array}$ & $\begin{array}{l}\text { Ринковий спосіб покарання підприємства за } \\
\text { масштабні помилки в менеджменті, пов’язаний з } \\
\text { реалізацією катастрофічних ризиків, що виникли в } \\
\text { процесі невдалої його фінансово-господарської } \\
\text { діяльності }\end{array}$ \\
\hline I.О. Бланк [1] & $\begin{array}{l}\text { Встановлена у судовому порядку фінансова } \\
\text { неспроможність підприємства, тобто його } \\
\text { нездатність задовольнити у встановлений строк } \\
\text { пред'явлені до нього з боку кредиторів вимоги і } \\
\text { виконати зобов'язання перед бюджетом }\end{array}$ \\
\hline $\begin{array}{l}\text { О.О. Терещенко } \\
{[7]}\end{array}$ & $\begin{array}{l}\text { Пов'язана з недостатністю активів у ліквідній } \\
\text { формі неспроможність юридичної особи } \\
\text { задовольнити в установлений для цього строк } \\
\text { заявлені до неї з боку кредиторів вимоги і } \\
\text { виконати зобов'язання перед бюджетом }\end{array}$ \\
\hline $\begin{array}{l}\text { А.Д. Шеремет, } \\
\text { Р.С. Сайфулин, } \\
\text { Є.В. Негашев [9] }\end{array}$ & $\begin{array}{l}\text { Неспроможність підприємства фінансувати } \\
\text { поточну операційну діяльність та погасити } \\
\text { зобов'язання }\end{array}$ \\
\hline $\begin{array}{l}\text { Джей К. Шим, } \\
\text { Джоел Г. Сігел } \\
{[10]}\end{array}$ & $\begin{array}{l}\text { Наступає тоді, коли підприємство не спроможне } \\
\text { сплачувати свої рахунки або його зобов'язання } \\
\text { перевищують ринкову ціну активів }\end{array}$ \\
\hline
\end{tabular}

недоліки, серед основних з яких можна зазначити наступні: недостатнє обгрунтування доцільності використання фінансових показників у моделях; не розвиненість українського фондового ринку; придатність застосування деяких моделей тільки для великих підприємств, які котирують свої акції на фондових біржах; не адаптованість моделей до специфіки української економіки; відмінність українського податкового та бухгалтерського законодавства від стандартів зарубіжних країн; суттєва розбіжність якісної інтерпретації даних, одержаних у результаті застосування різних моделей і навіть їх кардинальна протилежність. Ао того ж існуючі на сьогодні моделі оцінювання ймовірності настання банкрутства підприємств є застарілими, не ураховують сучасні особливості розвитку економіки. Тому з урахуванням статистичних даних українських підприємств потребують перегляду як застосовувані ключові показники у загальновідомих моделях, так і коефіцієнти вагомості, встановлені до них. Отже, виникає питання щодо визначення показників, здатних прогнозувати розвиток подій на ранніх стадіях банкрутства вітчизняних підприємств. Крім того, жоден з існуючих методичних підходів не дозволяє встановити наближення моменту ймовірності настання банкрутства підприємств з урахуванням горизонту прогнозування. Водночас у більшості випадків саме від часових обмежень повністю за- 
лежить вибір термінових заходів щодо виправлення фінансового стану підприємства, завчасне проведення яких дозволить відтермінувати настання банкрутства підприємства.

\section{МЕТА ДОСЛІДЖЕННЯ}

Мета дослідження - розробити методичний підхід, який, на відміну від існуючих, дозволить оцінювати ймовірності настання банкрутства підприємств з урахуванням горизонту прогнозування.

\section{ВИКЛАД ОСНОВНИХ РЕЗУЛЬТАТІВ ДОСЛІДЖЕННЯ}

Аля досягнення поставленої мети на основі статистичних даних та за допомогою дискримінантного аналізу доцільно розробити вираз, який характеризуватиме ймовірність настання банкрутства підприємств 3 урахуванням горизонту прогнозування та встановити його граничне значення, при досягненні якого ймовірність настання банкрутства перестає бути прийнятною.

Зазначимо, що думки дослідників розходяться відносно оптимальної кількості показників у моделях оцінювання ймовірності настання банкрутства підприємств. У той же час усе розмаїття підходів до побудови моделей оцінювання ймовірності настання банкрутства підприємств можна згрупувати на 3 групи, а саме:

1. Бальна система оцінювання з визначенням класу (індексу) ризикованості фінансового стану підприємства.

2. Однофакторний дискримінантний аналіз.

3. Багатофакторний дискримінантний аналіз.

При цьому відносно бальної системи оцінювання та однофакторного дискримінантного аналізу у роботі [6] підкреслюється наявність мультиколінеарності в результатах оцінки (тобто, ключові показники часто відображають взаємопов'язані об'єкти оцінювання, що порівняно з іншими показниками надміру посилює їх значимість в одержаних результатах розрахунків та викривляє результати оцінювання). Крім того, у якості недоліків однофакторного дискримінантного аналізу можна підкреслити можливість протилежних висновків по різних показниках (за одними можливі позитивні, а за іншими - негативні). Багатофакторний дискримінантний аналіз за допомогою стандартних критеріїв Фішера та Стьюдента дозволяє усунути мультиколінеарність кдючових показників, а також урахувати вагомість кожного показника під час оцінюван- ня. Розробка інтегрального показника оцінювання ймовірності настання банкрутства підприємств за допомогою багатофакторного дискримінантного аналізу грунтується на формулі (1):

$$
Z=\sum_{i=1}^{n} X_{i} \times k_{i}
$$

де $Z$ - показник оцінювання ймовірності настання банкрутства підприємств;

$X_{i}$ - значення показників оцінки фінансового стану підприємства;

$k_{i}$ - коефіцієнт вагомості відповідного показника, встановлений під час дискримінантного аналізу статистичної вибірки досліджуваних підприємств;

n- кількість показників оцінки фінансового стану підприємства.

Ретельно досліджено діяльність близько 100 українських підприємств (публічних та приватних акціонерних Товариств), які протягом 2018-2020 рр. перейшли до процедури проведення банкрутства, а також діяльність 100 підприємств - не банкрутів. За аналогією до моделі Альтмана статистичні дані щодо досліджуваних підприємств було згруповано на дві групи:

1) підприємства банкрути:

2) підприємства не банкрути.

Крім того, грунтовно проаналізовано 30 показників, що застосовуються під час оцінювання фінансового стану підприємств, та які могли бути придатними для прогнозування ймовірності настання банкрутства підприємств, у тому числі й ті, на яких побудовані загальновідомі моделі Е. Альтмана, Р. Аіса, У. Бівера, Р. Таффлера, Г. Спрінгейта, І. Бланка, К. Беєрмана, А. Чессера, О. Зайцевої, Р. Сайфулліна, О. Терещенко, А. Шеремета, М. Фєдотової, А. Матвійчука, Конана-Гольдера, Аавидової-Бєлікової, Проте проведені випробування підтвердили їх не придатність у існуючих комбінаціях для цілей оцінювання ймовірності настання банкрутства українських підприємств у сучасних умовах господарювання. Крім того, визначено недоцільність застосування ряду показників, що застосовуються у існуючих моделях оцінювання ймовірності настання банкрутства підприємств, наприклад:

- відношення чистого прибутку підприємства до його чистого доходу;

- відношення активів підприємства до його чистого АОходу;

- відношення чистого прибутку підприємства до собівартості його продукції (товарів, робіт, послуг) тощо. 
Це положення обгрунтовується тим, що збиткові підприємства можуть не мати чистого доходу, не виготовляти продукцію (товари, роботи, послуги), отже за даних обставин у якості знаменника вищезазначених показників буде нульове значення, що унеможливлює виконання математичних дій.

Також у ряді моделей, наприклад у моделі О. Зайцевої, застосовуються "обернені" фінансові показники (відношення величини кредиторської заборгованості підприємства до його дебіторської заборгованості; відношення величини поточних зобов'язань підприємства до його грошових коштів та їх еквівалентів), що не придатні для цілей оцінювання ймовірності настання банкрутства підприємств.

Зважаючи на вищенаведене у рамках цього дослідження під час побудови моделей оцінювання ймовірності настання банкрутства підприємств за допомогою кореляційно-регресійного аналізу було відібрано найкращі показники, що підтверджено проведеними тестами. Водночас урахування горизонту прогнозування під час побудови моделей оцінювання ймовірності настання банкрутства підприємств вплинуло на зміну комбінації даних показників та коефіцієнти вагомості, встановлені до них.

Таким чином, загалом розробка моделей оцінювання ймовірності настання банкрутства підприємств 3 урахуванням горизонту прогнозування включала такі етапи:

1. Аослідження діяльності українських підприємств (публічних та приватних акціонерних Товариств), які перейшли до процедури банкрутства, а також діяльність підприємств - не банкрутів. Водночас статистичні дані щодо досліджуваних підприємств було згруповано на дві групи: підприємства банкрути та не банкрути.

2. Ретельний аналіз 30 показників оцінки фінансового стану підприємств, які могли бути придатними для прогнозування ймовірності настання банкрутства підприємств, у тому числі й тих, на яких побудовані загальновідомі моделі оцінювання ймовірності настання банкрутства підприємств.

3. На підставі даних фінансової звітності підприємств-банкрутів та підприємств не банкрутів за допомогою інструментів статистики та кореляційно-регресійного аналізу визначено показники, які здійснюють суттєвий вплив на результативний показник.

4. На підставі обраних показників оцінки фінансового стану побудовано моделі прогнозування ймовірності настання банкрутства підприємств з урахуванням горизонту прогнозування.
Слід зазначити, що на підставі моделей оцінювання ймовірності настання банкрутства підприємств з урахуванням горизонту прогнозування можливо оцінити вірогідність настання цієї події протягом одного, двох, трьох, десяти років і т. д. У рамках цього дослідження в якості оцінюваного періоду обрано 3 роки, що настануть після поточного, який вважатимемо нульовим. Тобто пропонуємо розробити моделі, які дозволять прогнозувати ймовірність настання банкрутства підприємств протягом одного, двох та трьох наступних років.

Вважаємо, що під час побудови моделей оцінювання ймовірності настання банкрутства підприємств можуть бути включені дані за відповідними показниками та за низку років, що дозволить прогнозувати схильність підприємства до банкрутства 3 урахуванням горизонту прогнозування.

Під горизонтом прогнозування розуміємо строк дії прогнозу, виражений в роках, на який за прогнозною моделлю із достовірною точністю визначається ймовірність настання банкрутства підприємств.

У межах цього дослідження в якості оцінюваного періоду обрано 3 роки, що відповідає трьом етапам горизонту прогнозування: короткостроковий, середньостроковий та довгостроковий. Аля кожного етапу горизонту прогнозування вважаємо доцільним розробити й відповідну модель оцінювання ймовірності настання банкрутства підприємств, а саме:

1) короткостроковий горизонт прогнозування визначати на підставі моделі оцінювання ймовірності настання банкрутства підприємств протягом одного року;

2) середньостроковий горизонт прогнозування визначати на підставі моделі оцінювання ймовірності настання банкрутства підприємств протягом двох років;

3) довгостроковий горизонт прогнозування визначати на підставі моделі оцінювання ймовірності настання банкрутства підприємств протягом трьох років.

3 урахуванням вище наведеного на підставі даних фінансової звітності підприємств-банкрутів, що передують року початку процедури іхнього банкрутства, та даних останнього звітного року підприємств не банкрутів із застосуванням дискримінантного аналізу побудовано 4-х факторне лінійне рівняння (2), яке дозволяє оцінити ймовірність настання банкрутства підприємств протягом одного року, тобто 


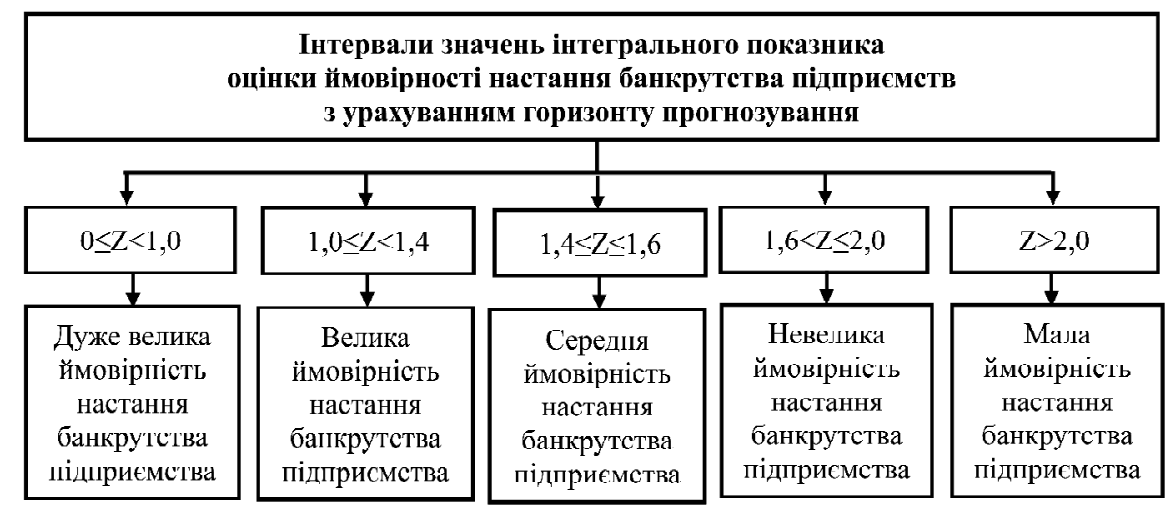

Рис. 1. Шкала визначення ймовірності настання банкрутства підприємств з урахуванням горизонту прогнозування

Ажерело: розроблено авторами.

у короткостроковому горизонті прогнозування $\left(Z_{1}\right)$ :

$Z_{1}=0,769 \mathrm{X}_{1}+0,194 \mathrm{X}_{2}+0,128 \mathrm{X}_{3}+0,771 \mathrm{X}_{4}+0,026(2)$,

де $\mathrm{X}_{1}$ - Оборотні активи / Активи;

$\mathrm{X}_{2}-$ Чистий дохід / Аебіторська заборгованість;

$\mathrm{X}_{3}$ - Активи / Зобов'язання;

$\mathrm{X}_{4}$ - Поточна дебіторська заборгованість / Поточні зобов'язання.

Коефіцієнти еластичності надають змогу визначити рівень впливу кожного фактору моделі на їі результативний показник. Аналіз одержаних даних дозволяє стверджувати про впливовість кожного показника у побудованій моделі $Z_{1}$, адже коефіцієнти еластичності, відповідно, становлять $32 \%, 18 \%, 20 \%$ та $28 \%$. Отже, питома вага неурахованих у моделі $\mathrm{Z}_{1}$ факторів становить лише $2 \%$, що підтверджує не суттєвість впливу будь-яких інших факторів на результативний показник та можливість їх ігнорування.

Аостовірність побудованої моделі підтверджується також значенням коефіцієнту детермінації, який становить 0,91 .

3 метою пояснення одержаних даних за розробленою моделлю оцінки ймовірності настання банкрутства підприємств, а також виключення неоднозначності щодо їх розуміння доцільно розробити відповідний ключ інтерпретації.

У роботі [5] освітлюються актуальні питання економічного розвитку українських промислових підприємств, у тому числі пропонується поділяти кризу фінансового стану за ступенями її важкості, а саме: відсутність кризи фінансового стану підприємства, його фінансова катастрофа, а також легкий, середній та важкий ступені кризи.

Рекомендовану авторами роботи [5] градацію вважаємо доцільним адаптувати для оціню- вання ймовірності настання банкрутства підприємств та застосовувати такі їі характеристики: мала, невелика, середня, велика та дуже велика ймовірності настання банкрутства підприємств.

Аля інтерпретації одержаних значень інтегрального показника оцінки ймовірності настання банкрутства підприємств з урахуванням горизонту прогнозування розроблено відповідну шкалу (рис. 1). Аля встановлення інтервалів значень даної шкали було застосовано метод колективних експертних оцінок (метод Аельфі).

Ураховуючи вище наведене припущення на підставі даних фінансової звітності підприємств-банкрутів за два роки до початку процедури їхнього банкрутства, та даних останніх двох років підприємств не банкрутів із застосуванням дискримінантного аналізу побудовано 4-х факторне лінійне рівняння (3), яке дозволяє оцінити ймовірність настання банкрутства підприємств протягом двох років, тобто у середньостроковому горизонті прогнозування $\left(Z_{2}\right)$ :

$Z_{2}=0,952 \mathrm{x}_{1}+0,155 \mathrm{x}_{2}+0,175 \mathrm{x}_{3}+0,273 \mathrm{x}_{4}+0,171(3)$,

де $\mathrm{X}_{1}$ - Оборотні активи / Активи;

$\mathrm{X}_{2}$ - Чистий дохід / Поточна дебіторська заборгованість;

$\mathrm{X}_{3}$ - Активи / Зобов'язання;

$\mathrm{X}_{4}$ - Поточна дебіторська заборгованість / Поточні зобов'язання.

Аналіз одержаних даних дозволяє стверджувати про впливовість кожного показника у побудованій моделі $\mathrm{Z}_{2}$, адже коефіцієнти еластичності, відповідно, становлять 17\%, 24\%, 18\% та $34 \%$. Отже, питома вага неурахованих у моделі $Z_{1}$ факторів становить лише $7 \%$, що підтверджує не суттєвість впливу будь-яких інших факторів на результативний показник та можливість їх ігнорування. 
Таблиця 2. Визначення ймовірності настання банкрутства підприємств з урахуванням горизонту прогнозування (розраховано авторами)

\begin{tabular}{|c|c|c|c|c|c|c|c|}
\hline $\begin{array}{c}\text { № } \\
\text { 3/ח }\end{array}$ & Назва підприємства & $\begin{array}{c}\text { Розраховане } \\
\text { значення } \\
\text { показника } \\
Z_{1}\end{array}$ & $\begin{array}{c}\text { Ймовірність } \\
\text { того, що } \\
\text { протягом } \\
\text { першого } \\
\text { року на } \\
\text { підприємстві } \\
\text { буде } \\
\text { впроваджена } \\
\text { процедура } \\
\text { банкрутства }\end{array}$ & $\begin{array}{c}\text { Розраховане } \\
\text { значення } \\
\text { показника } \\
\mathrm{Z}_{2}\end{array}$ & $\begin{array}{c}\text { Ймовірність } \\
\text { того, що } \\
\text { протягом } \\
\text { перших двох } \\
\text { років на } \\
\text { підприємстві } \\
\text { буде } \\
\text { впроваджена } \\
\text { процедура } \\
\text { банкрутства }\end{array}$ & $\begin{array}{c}\text { Розраховане } \\
\text { значення } \\
\text { показника } \\
Z_{3}\end{array}$ & $\begin{array}{c}\text { Ймовірність } \\
\text { того, що } \\
\text { протягом } \\
\text { перших } \\
\text { трьох років } \\
\text { на } \\
\text { підприємстві } \\
\text { буде } \\
\text { впроваджена } \\
\text { процедура } \\
\text { банкрутства }\end{array}$ \\
\hline 1. & $\begin{array}{l}\text { НАК «Нафтогаз } \\
\text { України» }\end{array}$ & 2,1 & Мала & 2,1 & Мала & 2,2 & Мала \\
\hline 2. & ПАТ «Укрнафта» & 1,6 & Середня & 1,6 & Середня & 2,1 & Мала \\
\hline 3. & $\begin{array}{l}\text { ПрАТ «Київська } \\
\text { кондитерська фабрика } \\
\text { "Рошен”») }\end{array}$ & 1,4 & Середня & 1,4 & Середня & 1,8 & Невелика \\
\hline 4. & ПАТ «Турбоатом» & 1,7 & Невелика & 1,8 & Невелика & 1,8 & Невелика \\
\hline 5. & $\begin{array}{l}\text { ПрАТ «Футбольний } \\
\text { клуб “Шахтар”» }\end{array}$ & 1,5 & Середня & 1,5 & Середня & 1,3 & Велика \\
\hline 6. & $\begin{array}{l}\text { ПрАТ «Мультіплекс- } \\
\text { Холдинг» }\end{array}$ & 1,3 & Велика & 1,2 & Велика & 1,5 & Середня \\
\hline 7. & $\begin{array}{l}\text { ПАТ «Концерн } \\
\text { Галнафтогаз» }\end{array}$ & 1,0 & Велика & 1,0 & Велика & 1,0 & Велика \\
\hline 8. & $\begin{array}{l}\text { ПАТ «Майдан- } \\
\text { Вильський комбінат } \\
\text { вогнетривів» }\end{array}$ & 0,9 & Дуже велика & 1,0 & Велика & 1,1 & Велика \\
\hline 9. & $\begin{array}{l}\text { ПАТ «Промислово- } \\
\text { виробниче } \\
\text { підприємство } \\
\text { “Кривбасвибухпром”» }\end{array}$ & 5,1 & Мала & 4,1 & Мала & 4,6 & Мала \\
\hline 10. & $\begin{array}{l}\text { ПАТ «Коростенський } \\
\text { машинобудівний } \\
\text { завод» }\end{array}$ & 1,5 & Середня & 1,6 & Середня & 1,8 & Невелика \\
\hline
\end{tabular}

Аостовірність побудованої моделі $\mathrm{Z}_{1}$ підтверджується також значенням коефіцієнту детермінації, який становить 0,78 .

Інтерпретацію одержаних значень інтегрального показника оцінки ймовірності настання банкрутства підприємств у середньостроковому горизонті прогнозування пропонуємо здійснювати на підставі шкали, наведеної на рисунку 1.

Грунтуючись на наведеному вище припущенні на підставі даних фінансової звітності підприємств-банкрутів за три роки до початку процедури їхнього банкрутства, та даних останніх трьох років підприємств не банкрутів із застосуванням дискримінантного аналізу побудовано 4-х факторне лінійне рівняння (4), яке дозволяє оцінити ймовірність настання банкрутства підприємств протягом трьох років, тобто у довгостроковому горизонті прогнозування $\left(\mathrm{Z}_{3}\right)$ :

$7_{3}=1,077 \mathrm{x}_{1}+0,257 \mathrm{X}_{2}+0,167 \mathrm{x}_{3}+0,128 \mathrm{x}_{4}+0,11$. (4), де $X_{1}$ - Оборотні активи / Активи;

$\mathrm{X}_{2}$ - Чистий дохіА / Аебіторська заборгованість;

$\mathrm{X}_{3}$ - Активи / Зобов'язання;

$\mathrm{X}_{4}^{3}$ - Поточна дебіторська заборгованість / Поточні зобов'язання.
Аналіз одержаних даних дозволяє стверджувати про впливовість кожного показника у побудованій моделі $Z_{3}$, адже коефіцієнти еластичності, відповідно, становлять 9\%, 23\%, 25\% та $38 \%$. Отже, питома вага неурахованих у моделі $\mathrm{Z}_{1}$ факторів становить лише $5 \%$, що підтверджує не суттєвість впливу будь-яких інших факторів на результативний показник та можливість їх ігнорування.

Аостовірність побудованої моделі $\mathrm{Z}_{3}$ підтверджується також значенням коефіцієнту детермінації, який становить 0,82 .

Інтерпретацію одержаних значень інтегрального показника оцінки ймовірності настання банкрутства підприємств у довгостроковому горизонті прогнозування пропонуємо здійснювати на підставі шкали, наведеної на рисунку 1.

Проведемо апробацію запропонованих моделей оцінювання ймовірності настання банкрутства підприємств 3 урахуванням горизонту прогнозування. Результати проведених розрахунків представлено у таблиці 2.

\section{ВИСНОВКИ І ПЕРСПЕКТИВИ ПОДАЛЬШИХ ДОСЛІДЖЕНЬ У ЦЬОМУ НАПРЯМІ}

Результати проведеної апробації підтверджують коректність запропонованих моделей 
оцінювання ймовірності настання банкрутства підприємств з урахуванням горизонту прогнозування та доцільність їх застосування. Водночас на підставі моделей оцінювання ймовірності настання банкрутства підприємств 3 урахуванням горизонту прогнозування можливо оцінити вірогідність настання цієї подї̈ протягом одного, двох або трьох років. Необхідно повністю ураховувати оцінюваний діапазон часу тобто:

1) якщо визначено, що протягом першого року ймовірність початку процедури банкрутства підприємства була малою або невеликою, але при цьому ймовірність початку процедури банкрутства підприємства протягом перших двох років діагностована як середня, велика або дуже велика, то видається доцільним визначати ймовірність початку процедури банкрутства підприємства у другому році;

2) якщо визначено, що протягом перших двох років ймовірність початку процедури банкрутства підприємства була малою або невеликою, але при цьому ймовірність початку процедури банкрутства підприємства протягом перших трьох років діагностована як середня, велика або дуже велика, то видається доцільним визначати ймовірність початку процедури банкрутства підприємства у третьому році.

Вирішення окреслених завдань є метою подальших досліджень.

\ітература:

1. Бланк И.А. Словарь-справочник финансового менеджера / И. А. Бланк. - Киев: НикаЦентр, 1998. - 480 с.

2. Брейли Р. Принципы корпоративных финансов / Р. Брейли, С. Майерс; пер. с англ. Н. Барышниковой. - Москва: ЗАО "Олимп-Бизнес", 2008. - 1008 c.

3. Кодекс України з процедур банкрутства від 18.10.2018, № 2597-VIII, зі змінами та доповненями. URL: https://zakon.rada.gov.ua/ laws/show/2597-19

4. Нусінова О.В. Основи оцінки економічної безпеки підприємств: теоретичні та практичні аспекти: монографія / О.В. Нусінова. К.: ТОВ "ПанТот", 2012. - 412 с.

5. Оценка кредитоспособности промышленных предприятий: авторские методики: монография / В.Я. Нусинов, Н.Н. Круглая, Е.В. Нусинова, Е.В. Мищук, Ю.А. Максак, С.П. Аобов; под ред. В.Я. Нусинова. - Кривой Рог: Издательский дом, 2007. - 315 с.

6. Терещенко О.О. Антикризове фінансове управління на підприємстві: монографія / O.O. Терещенко. - К.: КНЕУ, 2004. - 268 с.
7. Терещенко О.О. Фінансова санація та банкрутство підприємств / О. О. Терещенко. Київ: КНЕУ, 2000. - 412 с.

8. Фарсон Р. Менеджменет абсурда, парадоксы лидерства / Ричард Фарсон. - Киев: Издательство "София", 2001. - 240 с.

9. Шеремет А.А. Методика финансового анализа / А.А. Шеремет, Р.С. Сайфулин, Е.В. Негашев. - Москва: ИНФРА-М, 2000. - 208 с.

10. Шим Аж.К. Финансовый менеджмент: пер. с англ. / Ажей К. Шим, Ажоэл Г. Сигел. Москва: Информационно-издательский дом "Филинъ", 1996. - 400 с.

\section{References:}

Blank, I.A. (1998), Slovar'-spravochnik finansovogo menedzhera Finance Manager's Dictionary and Reference Book, Nika-Centr, Kyiv, Ukraine.

2. Brejli, R. and Majers, S. (2008), Principy korporativnyh finansov Principles of Corporate Finance, ZAO "Olimp-Biznes", Moscow, Russia.

3. The Verkhovna Rada of Ukraine (2018), The Law of Ukraine "Bankruptcy Code of Ukraine", available at: https://zakon.rada.gov.ua/laws/ show/2597-19 (Accessed 18 October 2018).

4. Nusinova, O.V. (2012), Osnovy otsinky ekonomichnoi bezpeky pidpryiemstv Fundamentals of assessing the economic security of enterprises, TOV "PanTot", Kyiv, Ukraine.

5. Nusinov, V.Ja. Kruglaja, N.N. Nusinova, E.V. Mishhuk, E.V. Maksak, Ju.A. and Lobov, S.P. (2007), Ocenka kreditosposobnosti promyshlennyh predprijatij: avtorskie metodiki [Assessment of the creditworthiness of industrial enterprises: author's methods], Yzdatel'skyj dom, Krivoj Rog, Ukraine.

6. Tereschenko, O.O. (2004), Antykryzove finansove upravlinnia na pidpryiemstvi Anti-crisis financial management at the enterprise, KNEU, Kyiv, Ukraine.

7. Tereschenko, O.O. (2000), Finansova sanatsiia ta bankrutstvo pidpryiemstv Financial rehabilitation and bankruptcy of enterprises, KNEU, Kyiv, Ukraine.

8. Farson, R. (2001), Menedzhmenet absurda, paradoksy liderstva [Management of the absurd, paradoxes of leadership], Sofija, Kyiv, Ukraine.

9. Sheremet, A.D. Sajfulin, R.S. and Negashev, E.V. (2000), Metodika finansovogo analiza Methodology of financial analysis, INFRA-M, Moscow, Russia.

10. Shim, Dzh.K. and Sigel, Dz.G. (1996), Finansovyj menedzhment Financial Management, Filin\#, Moscow, Russia.

Стаття надійшла до редакиї 15.04.2021 p. 
УAK $352.07(477.7)$

\author{
А. В. Ковальов, \\ к. с.-г. Н., доцент, доцент кафедри загадьноекономічної підготовки,
}

Херсонський Аержавний аграрно-економічний університет, м. Херсон

ORCID ID: 0000-0002-3672-7063

O. В. Черемісін,

А. і. н., професор, професор кафедри професійної освіти,

Херсонський Аержавний аграрно-економічний університет, м. Херсон

ORCID ID: 0000-0003-0173-0489

DOI: $10.32702 / 2306-6792.2021 .7-8.26$

\title{
РОАЬ МІСЬКОГО САМОВРЯАУВАННЯ ПІВАНЯ УКРАЇНИ В РОЗВИТКУ ТОРГІВАІ В АРУГІЙ ПОАОВИНІ ХІХ - ПОЧАТКУ ХХ СТ.
}

\author{
D. Kovalyov, \\ $\mathrm{PhD}$ in Agricultural Sciences, Associate Professor, Associate Professor of the Department \\ of General Economics, Kherson State agrarian and economic University, Kherson \\ O. Cheremisin, \\ Doctor of Historical Sciences, Professor, Professor of the Department of Trade \\ Education, Kherson State agrarian and economic University, Kherson
}

\author{
THE ROLE OF CITY GOVERNMENT OF THE SOUTH OF UKRAINE IN THE DEVELOPMENT \\ OF TRADE IN THE SECOND HALF OF XIX — EARLY XX CENTURY
}

У статті розглядається проблема участі міського самоврядування Півдня України в розвитку торгівельних відносин протягом другої половини XIX-XX ст. Актуальність теми визначається тим, що на сучасному етапі українського державотворення відбувається реформування системи державного управління на принципах децентралізації, що потребує проведення широких реформ. Основною метою цих реформ $є$ перетворення вже існуючої адміністративної та самоврядної системи на ефективний чинник прискорення соціально-економічного розвитку регіонів. Метою статті $\epsilon$ проаналізувати роль міського самоврядування Півдня України в розвитку торгівлі у капіталістичних умовах. МетоАологічну основу дослідження становлять підходи: системно-хронологічний, культурологічний, аксіологічний, порівняльний, ретроспективний. Зазначені підходи грунтуються на сукупності методологічних принципів, 3-поміж яких: діалектичний, системності, історизму, хронологічний, персоніфікований. У роботі використано комплекс методів дослідження: загальнонаукових, історико-педагогічних та спеціально-історичних. У висновках відзначено, що міське самоврядування Півдня України змогло виявити протягом досліджуваного періоду в розвитку торгівлі значну модернізаційну мобільність в оновленні портів, будівництві нових шляхів сполучення та інших заходах.

The article considers the problem of participation of the city self - government of the South of Ukraine in the development of trade relations during the second half of the XIX - XX centuries. The urgency of the topic is determined by the fact that at the present stage of Ukrainian state-building the system of public administration is being reformed on the principles of decentralization, which requires broad reforms. The main purpose of these reforms is to transform the existing administrative and self-governing system into an effective factor in accelerating the socio-economic development of the regions. The aim of the article is to analyze the role of urban self-government in the South of Ukraine in the development of trade in capitalist conditions. The methodological basis of the study are approaches: system-chronological, culturological, axiological, comparative, retrospective. These approaches are based on a set of methodological principles, including: dialectical, systematic, historicism, chronological, personalized. The set of research methods is used in the work: general scientific, historical-pedagogical and special-historical. The conclusions noted that the city self-government of the South of Ukraine was able to show during the study period in the development of trade significant modernization mobility in the renewal of ports, construction of new roads and other activities. Local self-government concentrated its thoughts by participating in this process. Each municipality was completely individual in the process of solving problems of trade development, renovation of port facilities and so on. They took loans on their own, planned, and hired specialists. Each public institution solved these problems completely independently at the meetings of the city councils without 
instructions from above, but only on its own initiative, taking into account the necessary set of needs of its own city, even by competing with others. In terms of competitiveness, the self-governments of the South of Ukraine have shown high mobility in this regard.

Ключові слова: Південь України, міське самоврядування, торгівля, капіталізм, сочіальноекономічний розвиток.

Key words: South of Ukraine, city self-government, trade, capitalism, socio-economic development.

\section{ПОСТАНОВКА ПРОБЛЕМИ}

На сучасному етапі українського державотворення відбувається реформування системи державного управління на принципах децентралізації, що потребує проведення широких реформ. Основною метою цих реформ $є$ перетворення вже існуючої адміністративної та самоврядної системи на ефективний чинник прискорення соціально-економічного розвитку регіонів.

Намагаючись сформувати сучасну систему місцевого самоврядування, суспільство не може не враховувати національно-історичний досвід діяльності місцевого самоврядування, оскільки управлінські відносини продовжують функціонувати в нових соціальних умовах як успадкована управлінська культура та технологія управління економічними процесами.

\section{АНАЛІЗ ОСТАННІХ ДОСЛІДЖЕНЬ І ПУБЛІКАЦІЙ}

Із розвитком української державності гостро постало питання створення нової соціально-політичної системи на основі децентралізації управління. Постановкою нових відносин центу та регіонів. За цих умов активізувалась зацікавленість дослідників досвідом існування систем міського самоврядування в кінці XVIII XX ст., оскільки в цей період часу також, проводився процес децентралізації. Тому в сучасних умовах досить актуальним $€$ проблема вивчення історичного досвіду.

Робота С. Надибської [8] розкриває залежність розвитку міст Півдня Російської імперії від портових операцій. Особливістю ринку південноукраїнських міст було те, що тут відбувалася концентрація товару, який був орієнтований на зовнішній ринок. Це відчутно впливало на економічне життя міст. Роль і місце чорноморських та азовських портів в історії України знайшли відображення в праці Федора та Галини Турченко [9]. Аослідники наголошують, що південні порти тісно пов'язували Україну і Європу та спрямували лівобережну та правобережну торгівлю в одному, південному напрямку.

Аосить докладно аналізується діяльність органів громадського самоврядування регіону в останній третині XIX - початку XX ст. у дослідженні $\Lambda$. Цибуленко [10], яка залучила сю- жети, присвячені участі самоврядування у розвитку торгівельних операцій та спробувала оцінити ефективність діяльності в цій області міських дум і управ.

У дисертації А. Аорошевої [4] досліджується діяльність міського самоврядування Херсона, Миколаєва, Одеси у другій половині XIX початку XX ст. У ній розкриваються співвідношення функцій і компетенції органів урядової адміністрації та місцевого самоврядування, визначаються особливості їх правової регламентації. Аається аналіз діяльності міських муніципалітетів щодо розбудови та модернізації портових споруд Одеси, Миколаєва й Херсона та визначено вплив здійснених перетворень на подальший розвиток міського господарства.

Питання розбудови і функціонування Одеського порту у другій половині XIX ст. досліджені І. Івасюком у статті "Проекти розбудови Одеського порту та їх реалізація в 60-ті та першій половині 70-х рр. XIX ст" [5]. Крім загальних тенденцій, автор висвітлив діяльність міської громадськості, спрямовану на поліпшення стану порту та системи комунікацій (передусім залізниці), які сприяли ефективному функціонуванню міських причалів, верфі та ін.

Одним із найбільш фундаментальних видань з історії Миколаївської області є "Історія рідного краю. Миколаївщина" (укладачі - В. Шкварець, Т. Мельник [12]. У ній пореформені роки розглянуті з точки зору невпинного розвитку та зростання міста. Збільшення міських прибутків за рахунок оподаткування товарів, що вивозилися через Миколаївський порт, спонукало думи та управи більше коштів витрачати на благоустрій. Це й замощення вулиць, й будівництво нових помешкань громадського призначення, й, звісно, заснування кінної залізниці.

\section{META CTATTI}

Метою статті $є$ проаналізувати роль місцевого самоврядування Півдня України в розвитку торгівельних відносин у капіталістичних умовах другої половини XIX - початку XX ст.

\section{ВИКЛАД ОСНОВНОГО МАТЕРІАЛУ}

Проблема збільшення темпів зовнішньої торгівлі через порти протягом XIX ст. привер- 
тала увагу купецтва, поміщиків, чиновників та інших соціальних груп населення міста та регіону загалом. Зростання конкуренції на західноєвропейських ринках продуктів, які завозилися з США, вимагало створення сприятливих умов для експорту хліба й інших товарів. Австрія та придунайські князівства, які мали в своєму розпорядженні розгалужену систему залізниць і модернізованих портових споруд перетворилися на початку 1860-х рр. на найбільш загрозливих конкурентів для портів Півдня України. Однією з умов розширення експорту було покращення роботи портів. Розвиток каботажного плавання, у тому числі пароплавних сполучень, також зумовив зростання попиту на їх послуги. Реорганізація процесу торгівлі й пароплавства приносила бажаний результат, але не повною мірою через неможливість прийняти більшу кількість суден у портах. Багато гаваней потребували очищення та поглиблення, моли - продовження та реорганізації (існуюча система устрою молів визнавалась дуже збитковою), набережні - проведення капітальних робіт [7, с. 7-18].

Із середини 1860-х рр. розпочалася модернізація південноукраїнських портових споруд. Від уряду було отримано допомогу й оголошені конкурси проектів. Це викликало зацікавлення з боку громадськості. У цих конкурсах брали участь і вітчизняні, й іноземні інженери. Було запропоновано кілька десятків різних проектів [4, с. 95-98].

Роль міського самоврядування при цьому зводилася до контролю за виконанням проектів. У південноукраїнських містах була відсутня механізація портів, тому муніципалітетами приймаються рішення про будівництво естакадних залізничних шляхів до морів, де відбувалося завантаження та розвантаження зернових. Це мало підвищити продуктивність праці та сприяти зниженню ціни на хліб. Цей процес сприяв поліпшенню економічного життя міст і збільшенню прибутків до бюджетів. 3 початку 1890-х рр. розпочинається проведення в порти електричного освітлення, будуються метеорологічні станції. Саме в цей час головним конкурентом південноукраїнських портів стають Сполучені Штати Америки, які продавали в 10-20 разів більше пшениці. Водночас містам Півдня України доводилося конкурувати з портами Балтійського моря, які мали більшу підтримку уряду. Що в подальшому вилилося в одну з причин місцевого сепаратизму, оскільки митні норми були більш сприятливими для портів Балтийського моря. Саме через них за кордон вивозилося найбільше товарів, особли- во промислового характеру. Через порти Чорного і Азовського морів вивозилась їх менша кількість. Тим більше, що за повідомленнями іноземців до портів Балтики привозили більш кращі і якісні товари ніж до портів Півдня України, в які через Марсель поступали вже другорядні товари, або ті, що вже вийшли з моди.

Іноземці вважали, що царська адміністрація не справедливо відноситься до портових міст Півдня митними тарифами, оскільки вони тормозили їх бурхливий модернізаційний, торгівельний та економічний розвиток.

На межі XVIII-XIX ст. чорноморськоазовські порти Півдня України змогли відтягнути на себе торгівельні відносини з країнами Західної Европи та Америки. Але до кінця XIX ст. найбільш значний торгівельний рух визначився між Одесою та Санкт-Петербургом та встановилась певна спеціалізація портів за торгівельними оборотами. Так, за даними 1896 р. найбільше промислових товарів за кордон вивозилося саме із портів Балтики, а із чорноморсько-азовських портів більше вивозилося хліба (173 млн пуд. проти 39 млн пуд. з Балтики) [11, с. 146-198].

Хоча царський уряд проводив відносно портів Півдня України наприкінці XVIII ст. протекціоніську політику з метою посилення колонізаційних процесів. Цілком допускалося, що і західні країни будуть більше цікавитися торгівельними відносинами через чорноморсько-азовські порти. Тому митні тарифи були розроблені з більшими перевагами для портів Півдня України, за допомогою яких вони відтягнули на себе більшу частину торгівлі із Балтики. Вже на початку XIX ст. уряд російської держави почали домінувати думки про розвиток положення порівняльних та абсолютних переваг на основі безперешкодного обміну товарами. Це вплинуло на загальну ситуацію розвитку торгівлі різних регіонів імперії.

3 розвитком інтернаціоналізації торговельного життя імперії підвищилась роль митних органів та митних ставок у різних регіонах держави. Вже у 1820-х рр. стало зрозуміло, що промисловість Росії та Англії не можуть конкурувати між собою. Тому відбулась тенденція на збільшення митних тарифів. За митним тарифом 1822 р. відбулась часткова заборона на ввезення імпортних товарів, що сприяло підвищенню цін, а також розвиткові одеської контрабанАи [6, с. 124-189].

Вже у 1850 р. за новим митним тарифом торгівля південноукраїнських портів була обмежена і протекціоніська політика була втрачена для регіону. Кримська війна негативно відобрази- 
лась на обсягах зовнішньої чорноморської торгівлі. В таких умовах були розроблені митні тарифи на основі вільної торгівлі, що зменшувало ставки на сільськогосподарську продукцію. Це в свою чергу призвело до того, що через чорноморсько-азовські порти стали в більшій мірі продавати зерно, а через порти Балтики промислову продукцію. У 1881 р. знову змінюються митні тарифи у бік протекціонізму, що позитивно посприяло на розвиток торгівлі південноукраїнського регіону і збільшення обсягів сільськогосподарської продукції $з$ регіону. Також позитивним моментом можна вважати розвиток промисловості регіону.

Митна політика в імперії мала регіональні особливості. Так, Фінляндія мала право у проведенні власної митної політики. Південь УКраїни мав можливості у розвитку промисловості та збільшення обсягів у вивезенні продуктів сільського господарства, а порти Балтики - у вивезенні промислової продукції.

Така політика уряду посприяла становленню південноукраїнських портів як центрів морського судноплавства із розміщенням в них пароплавних компаній, що стало показником успішного економічного розвитку регіону. У поєднанні із будівництвом залізниць була створена єАина транспортна система, яка пов'язувала Південь із центральними та прибалтійськими регіонами держави. Це призвело до виділення чорноморських портів на основні у плані експорту, а балтийські на головні порти в імпорті. На початку XX ст. уряд розвивав митну політику відносно розвитку власної промисловості. Це призвело до посилення в містах Півдня тенденцій, спрямованих на розуміння несправедливої політики уряду відносно регіону, а також до посилення сепаратиських тенденцій і збільшенні ролі міського патріотизму. Аержава використовувала Аонецький вугільний басейн для розвитку промисловості, але головними пунктами вивозу промислової продукції були порти Балтики. Головна регіонально-індивідуальна особливість Одеси полягала у тому, що митниця не входила до складу митних округів, а підпорядковувалася напряму департаменту митних зборів і мала назву головного митного сховищу [6, с. 218-368].

Недоліки південноукраїнських портів полягали в недостатній кількості доків, відсутності на озброєнні спеціального обладнання, нестачі ремонтних корабелень та обладнання для розколу льоду, що призводило зупинку робіт у зимовий період. Ао того ж міста Півдня України почали конкурувати між собою. Так, наприклад, конкурентом Херсона вважався Ми- колаїв, оскільки в ньому було краще оснащення порту та шляхи сполучення з центральними регіонами $[1$, с. $5-15 ; 2$, с. $5-10 ; 3$, с. $15-80]$.

Паралельно з розбудовою портів відбувалось і будівництво залізниці, яка повинна була з'єднати центральні райони держави з портами Чорного й Азовського морів. Уперше питання про будівництво залізниці постало ще в 1836 р., коли почала ясно простежуватись тенденція невідповідності між потребами у транспортній мережі та їі станом. У 1858 р. було створено державний комітет залізних шляхів. Розуміючи важливість будівництва залізниць для розширення шляхів сполучення на внутрішньому ринку та налагодження морської міжнародної торгівлі, зазначений комітет розробив низку проектів залізничного будівництва для південних губерній Російської імперії. Головне завдання у впровадженні залізниць полягало в прискоренні темпів доставки вантажів у порти. Кошти, які вдавалося отримувати від торговельних операцій, самоврядування витрачало на міський благоустрій.

\section{ВИСНОВКИ}

Таким чином, самоврядування Півдня України змогло виявити протягом досліджуваного періоду в розвитку торгівлі значну модернізаційну мобільність в оновленні портів, будівництві нових шляхів сполучення та інших заходах. Місцеве самоврядування шляхом участі у цьому процесі концентрувало думки. Кожен муніципалітет був цілком індивідуальним у процесі вирішення проблем розвитку напрямів торгівлі, оновленні портових споруд і так далі. Самостійно брали кредити, вели планування, наймали спеціалістів. Кожен громадський інститут вирішував ці проблеми цілком самостійно на засіданнях міських дум без вказівки зверху, а лише за власною ініціативою, враховуючи необхідний комплекс потреб власного міста, навіть шляхом конкуренції з іншими. 3 приводу конкурентоспроможності, то самоврядування Півдня України виявили високу мобільність у цьому відношенні. Тому до нового модернізаційно-урбаністичного життя увійшли лише ті міста Півдня України, які використали необхідний потенціал, який вимагав капіталістичний час. Модернізуючи порти, пов'язавши новими торгівельними шляхами повітові та заштатні міста із портовими, губернськими, центральними містами та регіонами міста Півдня України отримали нові умови існування, які значно перевищували показники інших регіонів держави. Порівняно із іншими регіонами України, Росії, Білорусії, Прибалтики самоврядування Півдня України демонструвало 
приклади позитивного прикладу нових модернізаційних можливостей. Якщо пік модернізації на Півдні припав на другу половину XIX ст., то в інших регіонах він лише розпочався на початку XX ст. Тому Південь України значно у вищих розмірах використав нові можливості модернізації.

\section{Мітература:}

1. Аержавний архів Херсонської області (далі - ААХО).Ф. 1. Оп. 1. Спр. 57. Аоклад херсонского губернатора о деятельности и развитии херсонского порта. Арк. 5-15.

2. ААХО. Ф. 1. Оп. 1. Спр. 58. Арк. 5-10.

3. ААХО. Ф. 1. Оп. 1. Спр. 60. Журналы заседаний херсонской городской думы, отчеты и контракты городской управы с фабрикантами и судовладельцами Вадоном, Спозито и др. на аренду земли для строительства доков. Арк. $15-80$.

4. Аорошева А.О. Самоврядування в приморських містах Півдня України у другій половині ХІХ ст.: дис. канд. іст. наук: 07.00.01. Одеca, 2009. C. 95-98.

5. Івасюк I.M. Проекти розбудови одеського порту та їх реалізація в 60-ті та першій половині 70-х рр. XIX ст.// Записки історичного факультету Одеського національного університету ім. Мечникова. Вип. 13. 2003. 305 с.

6. Колесников К.М. Історія митної справи в Україні. Київ: Знання, 2006. 606 с.

7. Паридо М. Записка о полукопеечном сборе для улучшения портовых сооружений и устройства мостовых в городе Николаеве. Николаев: Русская типо-литография, 1880. С. 7-18.

8. Надибська С.Б. Соціально-економічний розвиток міст Південної України в 18611900 рр. (за матеріалами Херсонскої та Катеринославської губерній): дис... канд.. іст. наук: 07.00.01. Oдеса, 2005. 150 c.

9. Турченко Ф.Г., Турченко Г.Ф. Південна Україна: модернізація, світова війна, революція (кінець XIX ст. - 1921 р.): Історичні нариси. К.: Генеза, 2003. С. 41-42.

10. Цибуленко М.О. Аіяльність органів самоврядування Одеси, Миколаєва, Херсона щодо формування і розвитку муніципальної земельної і виробничої власності в XIX - на початку XX століть: дис... канд.. іст. наук: 07.00.01. Аніпропетровськ, 2001. 180 с.

11. Фабрично-заводская промышленность и торговля России. СПб.: Тип. И.А. Ефрона, 1896. $786 \mathrm{c}$.

12. Шкварець В.П. Історія рідного краю. Миколаївщина: навчальний посібник. Миколаїв: МАГУ ім. П. Могили, 2004. 280 с.
References:

1. Derzhavnyi arkhiv Khersonskoi oblasti (2021), "Report of the Kherson governor on the activities and development of the Kherson port", F. 1. Op. 1. Spr. 57. Ark. 5-15.

2. DAKhO (2021), F. 1. Op. 1.Spr. 58. Ark. 5-10.

3. DAKhO (2021), "Journals of Kherson City Duma meetings, reports and contracts of the city council with manufacturers and shipowners Vadon, Spozito, etc. for the lease of land for the construction of docks", F. 1. Op. 1. Spr. 60. Ark. 15-80.

4. Dorosheva, A. O. (2009), "Self-government in the coastal cities of southern Ukraine in the second half of the XIX century", Ph.D. Thesis, History, Odesa, Ukraine, pp. 95-98.

5. Ivasiuk, I.M. (2003), "Projects for the development of the port of Odessa and their implementation in the 60's and first half of the 70's pp. XIX century", Zapysky istorychnoho fakultetu Odeskoho natsionalnoho universytetu im. Mechnykova, vol. 13.

6. Kolesnykov, K. M. (2006), Istoriia mytnoi spravy v Ukraini [History of customs in Ukraine], Znannia, Kyiv, Ukraine.

7. Parydo, M. (1880), Zapyska o polukopeechnom sbore dlia uluchshenyia portovikh sooruzhenyi y ustroistva mostovikh v horode Nykolaeve [A note on a half-kopek fee for the improvement of port facilities and the arrangement of pavements in the city of Nikolaev], Russkaia typolytohrafyia, Nykolaev, Russia, pp. 7-18.

8. Nadybska, S.B. (2005), "Socio-economic development of the cities of Southern Ukraine in 1861-1900 (according to the materials of Kherson and Ekaterinoslav provinces)", Ph.D. Thesis, History, Odesa, Ukraine.

9. Turchenko, F.H. Turchenko, H.F. (2003), Pivdenna Ukraina: modernizatsiia, svitova viina, revoliutsiia (kinets XIX st. - 1921 r.): Istorychni narysy [Southern Ukraine: modernization, world war, revolution (end of XIX century - 1921): Historical essays], Heneza, Kyiv, Ukraine, pp. 41-42.

10. Tsybulenko, L.O. (2001), "Activity of selfgovernment bodies of Odessa, Nikolaev, Kherson concerning formation and development of municipal land and industrial property in XIX in the beginning of XX centuries ", Ph.D. Thesis, History, Dnipropetrovsk, Ukraine.

11. Typ. Y.A. Efrona (1896), Fabrychnozavodskaia promishlennost y torhovlia Rossyy [Factory industry and trade in Russia], Typ. Y.A. Efrona, St.Petersburg, Russia.

12. Shkvarets, V.P. (2004), Istoriia ridnoho kraiu. Mykolaivshchyna [History of the native land. Mykolayiv region], MDHU im. P. Mohyly, Mykolaiv, Ukraine.

Стаття надійшла до редакчї 13.04.2021 p. 
УАK 332.012 .2

O. І. Аацій,

А. е. н., професор, завідувач кафедри фінансів, банківської та страхової справи,

Міжрегіональна Академія управління персоналом

ORCID ID: 0000-0002-7436-3264

О.О. Черняєва,

к. е. н., доцент кафедри фінансів, банківської та страхової справи,

Міжрегіональна Академія управління персоналом

ORCID ID: 0000-0002-6981-2491

I. I. Туболець,

к. е. н., доцент, доцент кафедри соціального забезпечення та податкової політики,

Університет митної справи та фінансів

ORCID ID: 0000-0002-4930-2427

DOI: $10.32702 / 2306-6792.2021 .7-8.31$

\title{
ФІНАНСОВІ РЕСУРСИ ЯК ОБ'СКТИВНИЙ ОБМЕЖУВАЧ МАСШТАБІВ АЕРЖАВНОГО РЕГУАЮВАННЯ ЕКОНОМІКИ ТА СОЦІААЬНОЇ СФЕРИ
}

\author{
O. Datsii, \\ Doctor of Economic Sciences, Professor, Head of the Department of Finance, \\ Banking and Insurance, Interregional Academy of Personnel Management \\ O. Cherniaieva, \\ $\mathrm{PhD}$ in Economics, Associate Professor of the Department of Finance, Banking \\ and Insurance, Interregional Academy of Personnel Management \\ I. Tubolets, \\ $\mathrm{PhD}$ in Economics, Associate Professor, Associate Professor of the Department of Social Security and Tax Policy, \\ University of Customs and Finance
}

\section{FINANCIAL RESOURCES AS AN OBJECTIVE LIMITER ON THE SCALE OF STATE REGULATION OF THE ECONOMY AND SOCIAL SPHERE}

\footnotetext{
Розвинуто підходи до фінансового регулювання соціально-економічних процесів, виявлено проблеми практичної реалізації регулюючих можливостей фінансів, розроблено рекомендацій щодо вдосконалення засобів і способів організації фінансового регулювання в сучасних умовах.

Встановлено, що кардинальне реформування економіки вимагає коригування напрямів фінансового впливу на соціально-економічний розвиток як України загалом, так і ї окремих регіонів. Послідовність процеАур, необхідних Аля вироблення відповідних рішень, включає в себе етап збору інформації про хіА суспільного відтворення, етап іï аналітичного узагальнення і власне акт прийняття рішення.

Визначено типи проблем, які вимагають невідкладного вирішення в сучасній управлінській діяльності: обмеженість інформаційно-методичного забезпечення управлінської Аіяльності; відсутність комплексного концептуального обгрунтування використання фінансів у системі державного регулювання; непідготовленість фінансового апарату до зАійснення цілеспрямованого впливу на окремі сегменти відтворення. Тому проблема визначення розумних меж фінансового перерозподілу стосовно до конкретних умов, безсумнівно, відноситься Ао розряду прагматично-перманентних.

Розкрито специфічний зміст фінансового регулювання соціально-економічних процесів та відзначено, що: потреба в наявності фінансових ресурсів пов'язана з виробництвом сукупних суспільних благ; ці ресурси забезпечують створення державних фондів грошових коштів акумуляційного характеру; в кінцевому підсумку вони преАставляють собою грошові кошти Аержавного бюАжету або регіону, які використовуються Аля виконання покладених на органи влади функцій і відображають підсумкові результати Аіяльності.
} 
Approaches to financial regulation of social and economic processes are developed, problems of practical realization of regulating possibilities of finance are revealed, recommendations on improvement of means and ways of the organization of financial regulation in modern conditions are developed. It is established that the radical reform of the economy requires the adjustment of the directions of financial influence on the socio-economic development of Ukraine as a whole and its individual regions.

The sequence of procedures required to make appropriate decisions includes the stage of collecting information about the course of social reproduction, the stage of its analytical generalization and the actual act of decision-making. The types of problems that require immediate solution in modern management are identified: limited information and methodological support of management; lack of a comprehensive conceptual justification for the use of finance in the system of state regulation; unpreparedness of the financial apparatus to exercise targeted influence on certain segments of reproduction.

Therefore, the problem of determining the reasonable limits of financial redistribution in relation to specific conditions, of course, belongs to the category of pragmatic and permanent. The specific content of financial regulation of socio-economic processes is revealed and it is noted that: the need for financial resources is connected with the production of aggregate public goods; these resources ensure the creation of state funds of accumulation funds; ultimately, they are funds from the state budget or region that are used to perform the functions assigned to the authorities and reflect the final results of activities.

Potentially, financial resources are formed at the stage of production, in the process of creating new and transferring previously created value. Their real formation takes place at the stage of redistribution, when a certain share of the product in cash is alienated in favor of the state. The total amount of the compensation fund (except for extraordinary situations - war, natural disaster on a national scale) should not be subject to centralized financial redistribution, as the opposite situation is likely to undermine the foundations of not only the state but also the entire social order. Only certain elements of the reimbursement fund, namely, working capital and depreciation of state-owned enterprises, may be involved in the scope of this redistribution. As for the newly created value, it is the main object of financial redistribution.

Ключові слова: економіка, обмежувач масштабів державного регулювання, сочіальна сфера, фінансові ресурси.

Key words: economy, limiter of state regulation, social sphere, financial resources.

\section{ПОСТАНОВКА ПРОБЛЕМИ}

ОАнією 3 ключових проблем суспільного розвитку $є$ питання про визначення місця і ролі держави в системі відтворення. Особливу значущість його рішення набуває в період трансформаційного реформування економіки України в соціально-економічній моделі. Становлення ринкових відносин в нашій країні відбувається в умовах істотних дисбалансів, наявних у національній економіці, браку інвестицій в реальний сектор економіки, інфляційних процесів, що продовжуються, мінімізації ресурсних можливостей для реалізації функцій держави, масштабного зростання зовнішнього боргу України. Все це обумовлює нагальну необхідність перегляду методів здійснення реформ і вдосконалення організаційних форм управління економікою, актуалізує наявність критеріїв конструктивності дій законодавчих і виконавчих органів влади.
Новий механізм державного регулювання соціально-економічних процесів повинен бути націлений на коригування ринкової рівноваги у випадках, коли останнє не відповідає суспільного благополуччя, він повинен забезпечити можливість виробництва суспільних товарів і послуг, необхідних для поступального розвитку країни. Реалізація об'єктивно існуючої потреби в централізованому впливі на економіку і соціальну сферу в чому залежить від ресурсного забезпечення заходів, що проводяться, внаслідок чого необхідною умовою вирішення основних завдань державного регулювання виступає процес формування та використання загальнодержавних грошових фондів. Їх призначення - сприяти задоволенню сукупних відтворювальних потреб, реалізацію яких конкурентний механізм не в змозі забезпечити в принципі або належним чином. Названі фонди формують матеріальну базу для виконання по- 
кладених на державу функцій, їх розмір є об'єктивним обмежувачем масштабів відповідного регулюючого впливу. Однією з найважливіших передумов підвищення ефективності централізованого управління сьогодні стає обов'язковий облік при розробці державних програм залежності між типом ринку і способами впливу на нього, з одного боку, і рівнем розвитку продуктивних сил, зрілістю організаційних структур і тенденціями зміни виробничих відносин, 3 іншого. Це вимагає систематичного вдосконалення форм організації фінансів, які, забезпечуючи можливість формування і використання загальнодержавних фондів грошових коштів, опосередковують значну частину економічних взаємозв'язків і справляють суттєвий вплив на хід відтворення.

\section{АНАЛІЗ ОСТАННІХ ДОСЛІДЖЕНЬ І ПУБЛІКАЦІЙ}

Підходи зарубіжних вчених до аналізу фінансових аспектів державного регулювання відрізняються яскраво вираженою емпіричної спрямованістю. Серед найбільш відомих сучасників правомірно виділити Е. Аткінсона, С. Брауна, I. Ванніскі, Аж. Кемпа, Р. Клауера, А. Маффера, Ф. Неймарка, А. Оукена, А. Пікока, Х. Розена, А. Стаффа, Аж. Стігліца, Ф. Флемінга, Р. Харрода, Г. Шоу. У нашій країні напрямки розвитку досліджень у цій області в сучасних умовах багато в чому визначаються працями таких авторів: О. Грабчук, О. Кириченко, В. Кравченко, М. Крупка, В. Корнєєв, А. Аисяк, А. Мазаракі, I. Чугунов та ін. Функціонування окремих елементів механізму фінансового регулювання економіки і соціальної сфери, організація однойменного процесу в конкретних державах, безумовно, є предметом вивчення досить великого кола економістів. Віддаючи належне значущості таких досліджень для розвитку фінансової науки і практики державного управління, слід зазначити, що кількість публікацій, присвячених комплексному аналізу названих питань, продовжує залишатися незначною, а самі дослідження, як правило, відрізняються недостатнім ступенем теоретичної розробки проблеми. Попри багатовікову історію використання фінансів у суспільному відтворенні, системне обгрунтування сутності та змісту фінансового регулювання не отримало ще належного відображення в економічній літературі, не вироблено загальновизнаного наукового визначення даного явища об'єктивної дійсності, відсутня чіткість у підходах до структурної побудови системи і механізму фінансового регулювання соціально економічних процесів.
Фрагментарність сприйняття накопиченого досвіду негативно позначається на формуванні фінансової стратегії української держави, на виробленні підходів до подолання найскладніших економічних, соціальних і територіальних диспропорцій в економічному розвитку країни. Проте необхідність комплексної розробки зазначеної тематики очевидна.

\section{META CTATT}

Метою дослідження $є$ розвиток теорії фінансового регулювання соціально-економічних процесів, виявлення проблем практичної реалізації регулюючих можливостей фінансів, розробка рекомендацій щодо вдосконалення засобів і способів організації фінансового регулювання в сучасних умовах.

\section{ВИКЛАД ОСНОВНОГО МАТЕРІАЛУ ДОСЛІДЖЕННЯ}

Специфіка українських реалій обумовлює особливу важливість переосмислення положень фінансової науки, і передусім тих питань, які пов'язані з розумінням ролі фінансів у життєдіяльності суспільної системи загалом, з виявленням можливостей їх використання для вирішення нагальних проблем відтворення, 3 розробкою методологічних підходів до організації процесу фінансового регулювання економіки і соціальної сфери в умовах недостатності інформаційного забезпечення та нестабільності параметрів розвитку.

Рушійною силою суспільного розвитку виступає, як відомо, задоволення людських потреб. Через об'єктивні причини соціум не може відмовитися від споживання благ, а відповідно, і від їх створення. У ньому систематично повинні відтворюватися засоби праці, предмети праці, робоча сила, а також відносини з приводу їх взаємодії один з одним. Відтворення являє собою процес створення благ, взятий в динаміці його безперервного відновлення і повторюваних зв'язків, тому крім власне виробництва воно охоплює фази розподілу, обміну та споживання суспільного продукту. Функціональна сукупність окремих елементів і процесів соціальної дійсності утворює систему суспільного відтворення. В рамках окремого господарства відтворення протікає в формі безперервного кругообігу відповідних доходів або капіталу і направлено на забезпечення життя і господарської діяльності конкретного суб'єкта. Водночас індивідуальні відтворювальні параметри не тільки усвідомлюються безпосеред- 
німи учасниками процесу, а й цілеспрямовано ними встановлюються і коригуються.

Оскільки ринкове господарювання базується на економічній відокремленості, матеріальної зацікавленості в задоволенні виражених через попит суспільних потреб і конкурентному типі взаємин між виробниками, першочергове значення на мікрорівні набуває проблема збільшення використовуваних засобів, тобто вартісний аспект руху ресурсів. Однак з огляду на характер суспільного виробництва потреби і можливості окремого товаровиробника в ході загальних обмінно-оціночних процедур пов'язуються 3 аналогічними параметрами інших суб'єктів економічних відносин. Це призводить до того, що досягнення мети максимізації індивідуального капіталу знаходиться в прямій залежності від ступеня матеріальногрошової збалансованості не тільки в рамках конкретного виробництва, але і в масштабах пов'язаних галузей, територій і в цілому національної економіки. В сучасних умовах, крім зазначених факторів, все більш вагому роль набуває також інтернаціоналізація світового господарства. Отже, відтворювальний процес на макрорівні відбувається як безперервний розвиток натурально-речових і вартісних форм руху економічних ресурсів, постійний кругообіг і передумова забезпечення цілісного функціонування всієї соціальної системи.

Кардинальне реформування економіки вимагає коригування напрямків фінансового впливу на соціально-економічний розвиток як України загалом, так і їі окремих регіонів. Послідовність процедур, необхідних для вироблення відповідних рішень, включає в себе етап збору інформації про хід суспільного відтворення, етап їі аналітичного узагальнення і власне акт прийняття рішення. Звертає на себе увагу тенденція ускладнення процесу фінансового регулювання з інформаційної сторони: розширюються обсяги використовуваних даних, ускладнюються методи ситуаційного аналізу та оформлення інформації, актуалізується потреба у збільшенні швидкості обробки і передачі відомостей, зростає потреба в посиленні модельної і прогностичної здатності інформаційно-аналітичного механізму регулювання.

Причетні до цих заходів державні структури України стикаються сьогодні, принаймні, 3 трьома типами проблем, які, на думку авторів, вимагають невідкладного вирішення: обмеженістю інформаційно-методичного забезпечення управлінської діяльності; відсутністю комплексного концептуального обгрунтування використання фінансів у системі державного регулювання; непідготовленістю фінансового апарату до здійснення цілеспрямованого впливу на окремі сегменти відтворення.

Рівень розвитку продуктивних сил, концентрація і усуспільнення виробництва, складність економічних і соціальних процесів, і широка розгалуженість міжрегіональних зв'язків і залежностей, породжують об'єктивну необхідність планомірного регулювання суспільних процесів. Організаційна заданість і конкретно-функціональна спрямованість фінансового регулювання, ефективність відповідного механізму безпосередньо пов'язані, на думку авторів, 3 конкретною мірою впливу. Звідси випливає, що основні складові моменти процесу фінансового регулювання економіки і соціальної сфери формуються на базі вирішення питань про масштаби і способи державного перерозподілу вартості. Центральне місце серед них займає пошук оптимальних пропорцій розподілу новоствореного доходу між загальнодержавними фондами грошових коштів, окремими підприємствами, організаціями та населенням.

Правильно встановлені пропорції перерозподілу ресурсів - це важливий чинник, що визначає результати функціонування економіки, впливає як на міру господарської самостійності суб'єктів відтворення, так і на ступінь стійкості матеріальної бази держави. Високий рівень вилучення доходів у підприємств і населення веде до падіння господарської активності, зменшення споживчих витрат, зниження сукупного попиту на ринку, що сприяє падінню виробленого ВВП, а згодом і потенційних доходів самої держави. Встановлення ж низького рівня вилучень одномоментно скорочує державні доходи i, як наслідок - звужує масштаби можливого державного регулювання. Тому проблема визначення розумних меж фінансового перерозподілу стосовно до конкретних умов, безсумнівно, відноситься до розряду прагматичноперманентних.

Показник "фінансові ресурси як макроекономічний параметр регулювання економіки" дозволяє погоджувати матеріально-речовинний і фінансово-вартісний аспекти відтворення і на цій основі регулювати пропорції соціально-економічного розвитку країни. Рівність між надходженням і витрачанням фінансових ресурсів - свідоцтво того, що частина платоспроможного попиту, яка формується державою, забезпечена матеріальним покриттям у вигляді суспільного продукту.

В економічній літературі дослідження даних питань не отримало широкого висвітлен- 
ня, більш того, спостерігається різне тлумачення самого поняття "фінансові ресурси", часто помилково ототожнюється з "грошовими коштами" і "грошовими фондами" [1-3]. За вихідну посилку при проведенні представленого аналізу прийнято розгляд фінансових ресурсів як сукупності грошових коштів, що використовуються органами державної влади для вирішення поставлених перед ними завдань.

Розкриваючи специфічний зміст зазначеного об'єкта дослідження, відзначимо, що:

- по-перше, потреба в наявності фінансових ресурсів пов'язана з виробництвом сукупних суспільних благ;

- по-друге, ці ресурси забезпечують створення державних фондів грошових коштів акумуляційного характеру;

- по-третє, в кінцевому підсумку вони представляють собою грошові кошти державного бюджету або регіону, які використовуються для виконання покладених на органи влади функцій і відображають підсумкові результати діяльності. У якості матеріальних носіїв фінансових відносин підлягають розгляду ресурси, які знаходяться в руках держави і мають фондову форму грошових коштів цільового призначення. Їх обсяг виступає важливою характеристикою економічного і соціального розвитку країни, а раціональне використання багато в чому визначає темпи суспільного прогресу. На практиці вони перетворені на уречевлену форму в різних фінансових фондах держави (централізованих: бюджетних і позабюджетних, а також децентралізованих: фондах грошових коштів державних підприємств і організацій та спеціальних ( позабюджетних) галузевих фондах).

\section{ВИСНОВКИ}

Потенційно фінансові ресурси утворюються на стадії виробництва, в процесі створення нової і перенесення раніше створеної вартості. Реальне ж їх формування відбувається на стадії перерозподілу, коли певна частка продукту в грошовій формі відчужується на користь держави. Сукупний обсяг фонду відшкодування (за винятком екстраординарних ситуацій війни, стихійного лиха національного масштабу) не повинен бути об'єктом централізованого фінансового перерозподілу, оскільки зворотна ситуація має ймовірність підриву основ існування не тільки самої держави, але і всього суспільного ладу. У сферу вказаного перерозподілу можуть бути залучені лише окремі елементи фонду відшкодування, а саме: оборотні кошти і амортизаційні відрахування державних підприємств. Що стосується новоствореної вартості, то саме вона є основним об'єктом фінансового перерозподілу.

\section{$\Lambda$ ітература:}

1. Грабчук О.М. Трансформації концептуальних засад бюджетної політики України. Економіка розвитку. 2017. № 3. С. 14-19.

2. Аисяк $\Lambda . В$. Бюджетна політика у системі державного регулювання соціально-економічного розвитку України: монографія. Київ: АННУ АФУ, 2009. 594 c.

3. Чугунов I.Я., Мазаракі А.А. Аержавне фінансове регулювання економічних перетворень: монографія. Київ: Київ. нац. торг. екон. ун-т, 2015. $376 \mathrm{c}$.

\section{References:}

1. Grabchuk, O. M. (2017), "Transformations of conceptual bases of budgetary policy of Ukraine", Ekonomika rozvitku, vol. 3, pp. 14-19.

2. Lisyak, L. V. (2009), Byudzhetna politika u sistemi derzhavnogo regulyuvannya socialnoekonomichnogo rozvitku Ukrayini: monografiya [Budget policy in the system of state regulation of socioeconomic development of Ukraine: monograph], DNNU AFU, Kyiv, Ukraine.

3. Chugunov, I. Ya. and Mazaraki, A. A. (2015), Derzhavne finansove regulyuvannya ekonomichnih peretvoren: monografiya [State financial regulation of economic transformations: a monograph], Kiyiv. nac. torg.- ekon. un-t, Kyiv, Ukraine. Стаття надійшла до редакиї 15.04.2021 p.

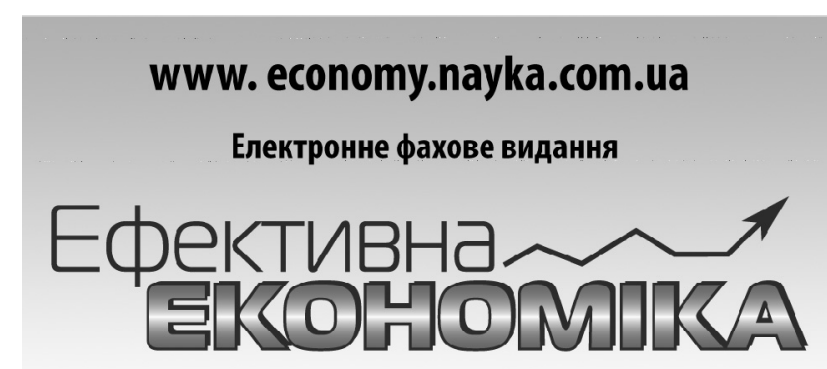

\section{Виходить 12 разів на рік}

Хурнал включено до переліку наукових фахових видань України з ЕКОНОМІЧНИХ НАУК (Категорія «Б»)

Спеціальності - 051, 071, 072, 073, 075, 076, 292

e-mail: economy_2008@ukr.net тел.: (044) 223-26-28

(044) $458-10-73$ 
УAK 338.43.01: 631.147(477.63)

\title{
I. А. Білоткач,
}

к. е. н., Аоцент, Аоцент кафедри маркетингу, Аніпровський Аержавний аграрно-економічний університет

ORCID ID: 0000-0002-8535-9252

DOI: $10.32702 / 2306-6792.2021 .7-8.36$

\section{ФОРМУВАННЯ СИСТЕМИ ІНСТИТУЦІОНААЬНОГО ЗАБЕЗПЕЧЕННЯ РОЗВИТКУ ОРГАНІЧНОГО АГРОПРОМИСАОВОГО ВИРОБНИЦТВА АНІПРОПЕТРОВСЬКОЇ ОБААСТI}

\author{
I. Bilotkach, \\ $\mathrm{PhD}$ in Economics, Associate Professor, Associate Professor of the Department of Marketing, \\ Dnipro State Agrarian and Economic University, Ukraine
}

\section{FORMATION OF THE SYSTEM OF INSTITUTIONAL SUPPORT OF DEVELOPMENT OF ORGANIC AGRO-INDUSTRIAL PRODUCTION OF DNIPROPETROVSK REGION}

Мета. Аналіз сформованої інституціональної бази України стосовно розвитку органічного сектору в сільському господарстві України, яка закріплена в законодавчіх актах та інших нормативних документах щодо формування сталого розвитку органічного агровиробництва на регіональному рівні; визначити інституціональну сутність економічної системи регіонів України, їі складові елементи, структуру; узагальнити науковий досвіА щодо подальшого удосконалення інституціональної системи України для сталого розвитку органічного агробізнесу в Україні.

Методика дослідження. Теоретико-методологічною основою проведеного дослідження є діалектичний та аналітичний підхід Ао вивчення існуючих інституціонадьних та інституційних особливостей стану та розвитку ринку органічної сільськогосподарської продукції та особливостей розвитку і регулювання органічного агровиробництва в Україні на регіональному рівні.

Результати дослідження. Стверджується, що нині, в умовах проведення реформи децентралізації влади, в Україні змінюється система Аержавного управління регіональним розвитком, що в окремих випадках призводить Ао погіршення показників ефективної діяльності регіонів, зокрема, в сфері сільськогосподарського виробництва.

Наголошується, що недоліки існуючих форм інституціонального регулювання економічних процесів на регіональному рівні, слабка взаємодія складових інституціональної територіальної системи стали факторами, що посилили негативні процеси в країні і суттєву соціально-економічну дисгармонію розвитку територій, а потреба в розвитку органічного агровиробництва як однієї із форм диверсифікації сільськогосподарського виробництва, створення Аієвої й ефективної системи інститутів розвитку органічного сектору $є$ в наш час одними 3 першочерговим завдань органів регіонадьної влади, у зв'язку з чим актуальним завданням $\epsilon$ формування ефективної системи інституціонального забезпечення розвитку органічного агропромислового виробництва регіону.

Проведено систематизацію інституційних чинників, які сприяють розвитку системи органічного виробництва в регіонах України на прикладі Аніпропетровської області. Ці фактори структуровані відповідно до інституціональної структури регіону, яку формують інститути регіонального рівня. Виділення цих факторів дає мождивість визначати стан регіонального розвитку щодо розвитку органічного агровиробництва, як у загальному, так і в інституціональному аспектах, орієнтуючись на структуру (систему) інститутів, що забезпечують сталий розвиток сучасного регіону.

Наукова новизна результатів дослідження. Запропоновано авторське визначення сутності терміну "інституціональна система підтримки органічного агропромислового виробництвана регіональному рівні" та розроблено структурно-логічну схему зв'язків між основними інституціональними чинниками на регіональному рівні, зокрема в Аніпропетровській області. Також пропонується авторська система заходів щодо ефективного впровадження органічного агровиробництва на регіональному рівні.

Практична значущість результатів дослідження. Отримані результати дослідження поглиблюють теоретичні аспекти розвитку та забезпечують можливість активізації інноваційного процесу органічного агровиробництва в Україні на регіональному рівні.

Purpose. Analysis of the current institutional framework of Ukraine regarding the development of the organic sector in agriculture of Ukraine, which is enshrined in legislation and other regulations on the impact on the formation of sustainable development of organic agriculture at the regional level; to determine the institutional essence of the economic system of the regions of Ukraine, its constituent elements, structure; to generalize scientific experience on further improvement of the institutional system of Ukraine for sustainable development of organic agribusiness in Ukraine. 
Methodology of research. The theoretical and methodological basis of the study is a dialectical and analytical approach to the study of existing institutional and institutional features of the state and development of the market of organic agricultural products and features of development and regulation of organic agriculture in Ukraine at the regional level.

Findings. It is argued that at present, in the context of decentralization reform, the system of public administration of regional development is changing in Ukraine, which in some cases leads to a deterioration in the efficiency of the regions, in particular in the field of agricultural production.

It is emphasized that the shortcomings of existing forms of institutional regulation of economic processes at the regional level, weak interaction of components of the institutional territorial system have become factors that exacerbated the negative processes in the country and significant socio-economic disharmony, and the need for organic agricultural production production, creating an effective and efficient system of institutions for the development of the organic sector are now one of the priorities of regional authorities, in connection with which the urgent task is to form an effective system of institutional support for the development of organic agro-industrial production in the region.

Institutional factors that contribute to the development of the system of organic production in the regions of Ukraine on the example of Dnipropetrovsk region are systematized. These factors are structured according to the institutional structure of the region, which is formed by institutions at the regional level. The selection of these factors makes it possible to determine the state of regional development in relation to the development of organic agriculture, both in general and in institutional aspects, focusing on the structure (system) of institutions that ensure sustainable development of the modern region.

Originality. The author's offered definition of the essence of the term "institutional system of support of organic agro-industrial production at the regional level" and the structural-logical scheme of connections between the main institutional factors at the regional level, in particular in the Dnepropetrovsk region. The author's system of measures for effective implementation of organic agricultural production at the regional level is also proposed.

Practical value. The obtained results of the research deepen the theoretical aspects of development and provide an opportunity to intensify the innovative process of organic agricultural production in Ukraine at the regional level.

Ключові слова: органічна сільськогосподарська продукиіл, органічне агровиробничтво, регіон, розвиток, інститучіоналізм, органічне агровиробничтво, чинники, вплив, система, якість життя.

Key words: organic agricultural products, organic agricultural production, region, development, institutionalism, organic agricultural production, factors, impact, system, quality of life.

\section{ПОСТАНОВКА ПРОБЛЕМИ}

Одним із головних питань у розвитку економіки України є забезпечення її сталого розвитку, під яким розуміється рівновага розвитку середовища людей та природного середовища, в якому людство розвиває свою діяльність. Основою будь-яких інституціональних та інституційних змін $є$ система інституціонального та інституційного розвитку соціально-економічних явищ на рівні територіальних одиниць держави, взаємовідносини їі складових частин між собою, а також ефективна інтеграція зазначеної регіональної системи з системою розвитку органічного виробництва на загальнодержавному рівні [8].

Нині в умовах проведення реформи децентралізації влади, в Україні змінюється система державного управління регіональним розвитком, що в окремих випадках призводить до погіршення показників ефективної діяльності регіонів, зокрема в сфері сільськогосподарського виробництва.

Недоліки існуючих форм інституціонального регулювання економічних процесів на регіональному рівні, слабка взаємодія складових інституціональної територіальної системи ста- ли факторами, що посилили негативні процеси в країні і суттєву соціально-економічну дисгармонію розвитку територій, а потреба в розвитку органічного агровиробництва як однієї із форм диверсифікації сільськогосподарського виробництва, створення дієвої й ефективної системи інститутів розвитку органічного сектору є в наш час одними з першочергових завданням органів регіональної влади, у зв'язку з чим актуальним завданням $є$ формування ефективної системи інституціонального забезпечення розвитку органічного агропромислового виробництва регіону.

\section{АНАЛІЗ ОСТАННІХ ДОСЛІДЖЕНЬ І ПУБЛІКАЦІЙ}

Різні аспекти оцінки сталого середовища розглядали у своїх наукових працях багато вітчизняних і закордоних науковців, а саме: I. Бистрякова, В. Благодатного, 3. Бриндза, В. Будзяк, В. В'юн, П. Гайдуцький, О. Гудзинський, П. Саблук, М. Куницька-Іляш, Т. Мозинська, І.Червен, М.Куліш, В. Месель-Веселяка, В. Гречкосй., І. Гуровата, $\Lambda$. Мельник, Є. Мішеніна, Т Ніколієнко, В. Тарасова, О. Фурдичка O.I., та інших. 
Теоретичним і прикладним аспектам впровадження та розвитку ринку органічної проАукції присвячені праці таких науковців: Р.М. Безус, И.Г. Мельник, А.С. Гринів, В.В. Підліснюк, B.I. Артиш, М.I. Кобець, В.В. Писаренко, В.Ф. Сайко, Б.В. Буркинський, Є.В. Милованов, Т.О. Зайчук, Т.Г. Аудар та інші поважні науковці.

Аослідженню розвитку інституціональних процесів в економіці загалом і в сільському господарстві присвячено наукові праці О. Гончаренко, С. Ілляшенко, $\Lambda$. Антонюка, Н. Апатової, Ю. Бажала, В. Вишневського, В. Гейця, В. Аементьєва, П.М. Аеоненко, В.Н. Тарасевича, П. Юхимчука, А. Чухно, Ю. Яковця та інші не менше поважні особистості.

Aле стрімкий розвиток органічного агровиробництва в Україні, розвиток ринку органічної сільськогосподарської продукції і потреба його раціонального оптимального входження в загальну систему аграрного бізнесу в Україні, сприяння сталому розвитку економічних процесів як у сільськогосподарській галузі, так і в дотичних галузях народного господарства потребує впровадження такої форми організації регіонального розвитку яка б дозволила оптимізувати інституціональні системи органічного сектору та поліпшити загалом економічну ситуацію щодо сталого розвитку сільського господарства та окремих його галузей як на регіональному рівні, так і в державі.

\section{META CTATTI}

У матеріалах дослідження, представлених у статті, ставиться за мету аналіз сформованої інституціональної бази України стосовно розвитку органічного сектору в сільському господарстві України, яка закріплена в законодавчіх актах та інших нормативних документах щодо впливу на формування сталого розвитку органічного агровиробництва на регіональному рівні; визначити інституціональну сутність економічної системи регіонів України, її складові елементи, структуру; узагальнити науковий досвід щодо подальшого Удосконалення інституціональної системи України для сталого розвитку органічного агробізнесу в Україні.

Об'єктом дослідження є стан та розвиток інституціональної системи Аніпропетровської області України, що формують складові органічного сільськогосподарського виробництва та розвиток ринку органічної сільськогосподарської продукції.

Предметом дослідження є сукупність інституціональних чинників, що використовуються, та використання яких можливе при формуванні регіонального розвитку України та їх вплив на розвиток органічного агровиробництва.

\section{ВИКЛАД ОСНОВНОГО МАТЕРІАЛУ ДОСЛІДЖЕННЯ}

Розвиток органічного виробництва та ринку органічної сільськогосподарської продукції $€$ актуальною сферою діяльності на сьогодні через низку явних екологічних, економічних та соціальних переваг, що притаманні цій сфері діяльності. Сектор виробництва та реалізації органічної продукції України характеризується позитивною і сталою динамікою, причому ці тенденції збігаються із загальносвітовими.

Міжнародна федерація органічного сільськогосподарського руху (IFOAM) визначає органічне сільське господарство як виробничу систему, яка підтримує здоров'я грунтів, екосистем і людей. Воно залежить від екологічних процесів, біологічного різноманіття та природних циклів, характерних для місцевих умов, уникаючи. Органічне сільське господарство об'єднує традиції, нововведення й наукові досягнення, щоб поліпшити стан навколишнього середовища і розвиток справедливих взаємовідносин та гідного рівня життя [1].

Враховуючи форму державного усторою, а Україна є унітарною державою, основні нормативні документи що регламентують розвиток органічного агровиробництва в Україні приймаються на загально-державному рівні. 3 метою удосконалення інституційного регулювання органічного виробництва, зберігання, транспортування обігу та маркування органічної продукції та адаптації вимог органічного законодавства до права ЄС (оскільки більше 70\% органічної продукції виробленої в Україні експортується до країн ЄС) Верховною Радою України був прийнятий новий Закон України "Про основні принципи та вимоги до органічного виробництва, обігу та маркування органічної продукції" (№ 2496-VIII, набрав чинності 02 серпня 2018 р., вступив в дію з 02 серпня 2019 р.) [4].

У розвиток прийнятого Закону розроблено прийнято 12 нормативно-правових актів із яких 3 Постанови Кабінету Міністрів України та 9 наказів різного рівня:

- Постанова Кабінету Міністрів України від 23 жовтня 2019 року № 970 "Про затвердження порядку (детальних правил) органічноговиробництва та обліку органічної продукції", в якій відповідно до частини другої статті 13 вищеназваного Закону України визначено детальні правила органічного виробництва та обігу органічної продукції таких галузей органіч- 
АГРОСВIT № $7-8,2021$

ного виробництва: органічне рослинництво (зокрема, насінництво та розсадництво); органічне тваринництво (зокрема, птахівництво, бджільництво); органічне грибівництво (зокрема вирощування органічних дріжджів); органічна аквакультура; виробництво органічних морських водоростей; виробництво органічних харчових продуктів (зокрема, органічне виноробство); виробництво органічних кормів; заготівля органічних об'єктів рослинного світу;

Постанова Кабінету Міністрів України від 12 лютого 2020 року № 87 "Порядок ведення Аержавного реєстру операторів, що здійснюють виробництво продукції відповідно до вимог законодавства у сфері органічного виробництва, обігу та маркування органічної продукції, Аержавного реєстру органів сертифікації у сфері органічного виробництва та обігу органічної продукції, Аержавного реєстру органічного насіння і садивного матеріалу". Відповідний документ упорядковує: рееєстр операторів органічного ринку, що формується на підставі інформації органів сертифікації та/ або реалізацію органічного насіння та/або садівного матеріалу; Реєстр органів сертифікації формується на підставі заявки підприємств, установ та організацій, які пройшли акредитацію в НААУ; Реєстр органічного насіння і садивного матеріалу формується на підставі інформації від оператора, який здійснює виробництво [8].

Також врегламентовано Форма заявки на внесення до Аержавного реєстру органів сертифікації у сфері органічного виробництва та обігу органічної продукції (наказ Мінекономіки від 30.01.2020 р. № 109, зареєстрований в Мін'юсті 14.02.2020 р. за № $173 / 34456$ );

Порядок підтвердження спеціальних знань інспектора з органічного виробництва та (або) обігу органічної продукції у сфері органічного виробництва (наказ Мінагрополітики від 19.03.2019 р. № 143 зареєстр. в Мін'юсті 09.04.2019 р. за № 375/33346);

Порядок розгляду апеляцій на рішення органів сертифікації (наказ Мінекономіки від17.06.2020 p. № 1141 зареєстрований в Мін'юсті 19.08.2020 р. № 805/35088).

Також визначено державний логотип для органічної продукції - Наказ Мінагрополітики від 22.02.2019 р. № 67 "Про затвердження державного логотипа для органічної продукції", зареєстрований в Мін'юсті 14.03.2019 р. за № 261/33232 (із змінами, внесеними наказом Мінекономіки від 15.07.2020 р. № 1336, зареєстрованим в Мін'юсті 31.07.2020 р. за № 729/ 35012), який має наступний вигляд (див. рис. 1).

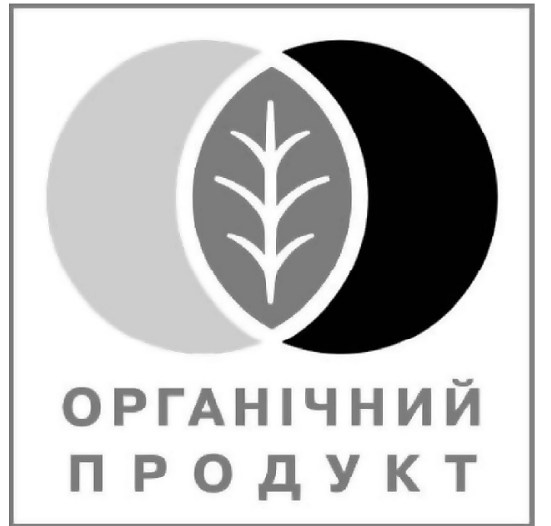

\section{Рис. 1. Чорно-білий вид державного логотипа для маркування органічної продукції}

Ажерело: [7].

У базових прийнятих нормативно-правових документах враховано вимоги нормативних документів $Є С$, що дозволить адаптувати українське законодавство до європейського; удосконалено вимоги до виробництва, маркування та обігу органічної продукції; та внесено інші вимоги як для виробників, так і інших потенційних суб'єктів ринку органічної сільськогосподарської продукції та органів сертифікації та контролю [4].

Нині проходять громадське обговорення такі нормативні акти:

- проект постанови КМУ "Про затвердження Порядку сертифікації органічного виробництва та/або обігу органічної продукції";

- проект наказу Мінекономіки "Про затвердження вимог до матеріально-технічної бази та інших об'єктів інфраструктури, необхідних для виконання функцій із сертифікації органічного виробництва та/ або обігу органічної продукції";

- проект наказу Мінекономіки щодо затвердження порядку звітування органів сертифікації Мінекономіки та Аержпродспоживслужбі про видані ними сертифікати;

- проект наказу Мінекономіки про затвердження порядку, періодичності декларування та подання зведених матеріалів органами сертифікації до Мінекономіки щодо обсягів органічної продукції, що вводиться в обіг [7].

Аля вдосконалення розвитку сільського господарства на регіональному рівні, зокрема, у Аніпропетровській області потрібно детально розробити заходи адміністративно-економічного регулювання щодо можливості ефективного розвитку органічного агровиробництва, яке є важливою передумовою формування продовольчої безпеки країни, економічного 


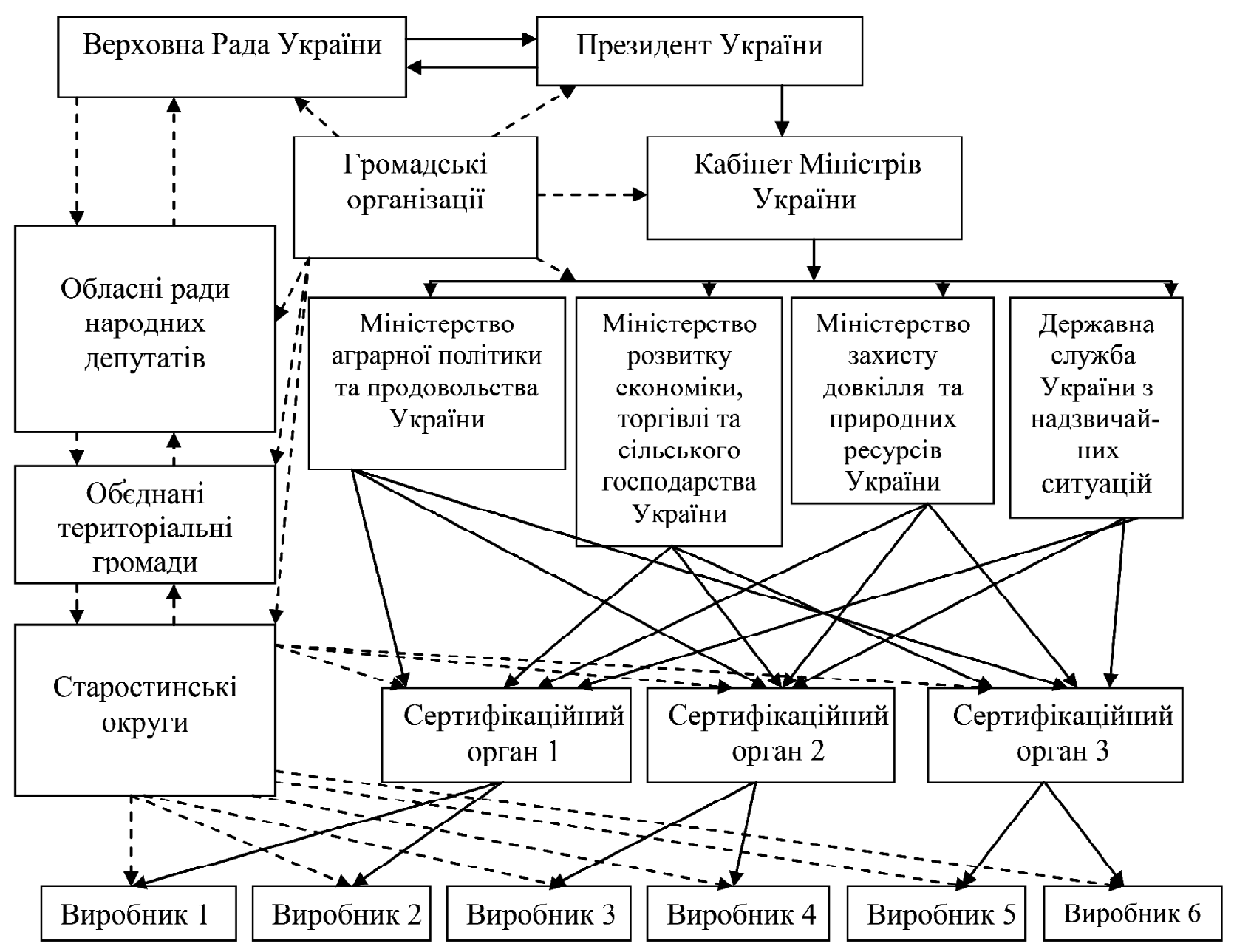

Рис. 2. Структурно-логічна схема формування формальних обмежень органічного агровиробництва

Ажерело: удосконалено автором на остнові [4].

зростання національної економіки та підвищення конкурентоспроможності сільського господарства і якості життя сільського населення, зокрема за рахунок популяризації органічного виробництва та вдосконалення інституціонального та інституційного механізмів формуючих чинників.

Розглядаючи формальні обмеження, зазначимо, що будь-яка поведінка підприємств обмежена певними правилами функціонування встановлених суспільством і ним же контрольованих норм, тобто наявністю певних інституціональних обмежень. Формальні інституціональні обмеження створюються державними структурами на різних рівнях владної вертикалі. Водночас у той час як загально-державний рівень формує система інституцій загальнодержавного порядку, регіональний рівень формується системой власних інституцій, що формується органами регіональної та місцевої влади в межах своїх повноважень [3].
Схематично вплив формальних обмежень на органічне агровиробництво можна представити у вигляді схеми наведеної на рисунку 2.

На схемі (рис. 2) прямими лініями позначено прямі функціональні зв'язки, а пунктирними лініями позначено зв'язки консультаційного та узгоджувального характеру.

Формальні обмеження визначаються як система факторів, що спрямовує економічну поведінку суб'єктів господарювання, а також споживачів виробленої продукції. Ао цієї системи обмежень відносяться нормоутворюючі документи, що перебувають під контролем 3 боку держави та місцевих органів влади. Введення таких обмежень здійснюється з метою організації ефективного адміністрування взаємовідносин у суспільстві, контролю за обігом товарів і послуг, недопущення проникнення на ринок неякісної або фальсифікованої продукції та інших складових, що забезпечують виконання функцій держави по відношенню до суспільства. Також нині потрібно враховувати 
значний вплив громадських організацій на всі процеси, що відбуваються у суспільстві [2].

Щодо розвитку органічного агровиробництва дуже важливим є його розвиток на рівні регіонів.

Органічне землеробство є високопрофесійною сертифікованою діяльністю, і тому для його впровадження потрібні навчання та практика, перш ніж виробники в сільському господарстві можуть бути повністю готовими до успішного ефективного ведення цього бізнесу.

На регіональному рівні передусім повинні проводитися заходи по навчанню основам органічного господарювання. Це питання може бути вирішено шляхом організації громадських організацій та рухів, в яких виробники органічної сільськогосподарської продукції будуть мати можливості спілкуватися між собою та надавати фахові консультації новим членам, які будуть мати у цьому потребу.

Аієвість механізму розвитку регіонального ринку органічної сільськогосподарської продукції в державі прямо залежить від якісного формування системи факторів інституційного середовища взагалі та зокрема на регіональномку рівні, яке являється виміром імперативного координування ринку органічного агровиробництва.

Потррібно враховувати що органічне сільське господарство є одним із альтернативних напрямів для диверсифікації виробництва, а отже, і для диверсифікації джерел доходу серед дрібних фермерів - однієї з основних груп аграрних господарств Аніпропетровської області. Станом на 01.01.2021 року в Аніпропетровській області зареєстровано всього 103645 юридичних осіб, з них фермерські господарства складають 3917 одиниць [9].

Починаючи процес переходу до ведення органічного аграрного бізнесу, також важливо бути готовим до викликів, які супроводжують зміни в агросистемі. Апріорний перехід до органічного сільського господарства формує така система факторів:

- зменшення урожайністі сільськогосподарських культур і доходу (особливо під час перехідного процесу);

- підвищена потреба в удосконаленні інфраструктурі або додаткових інструментаріях, технологіях та обладнанні;

- підвищення потреби в підготовленній до застосування органічних технологій робочій силі;

- труднощі з отриманням доступу до місцевого (а також регіонального та міжнародного) ринку органічної сільськогосподарської продукції [12].
Успішне вирішення цих проблем багато в чому залежатиме від креативності стейкхолдерів, навчання на чужому досвіді та доступу до інформації про алгоритми успішних вирішень аналогічних завдань на регіональному рівні.

Щодо загальних пропозицій та рекомендацій впровадження органічних технологій в сільськогосподарську діяльність господарств Аніпропетровської області, то ми пропонуємо такі кроки:

1. Здійснити повну паспортизацію земельних ділянок господарств 3 можливим виділенням конкретних земельних ділянок для ведення органічного агровиробництва, а за необхідності створення окремих структурних, або юридичних одиниць Аля можливого уникнення паралельного виробництва культур;

2. Забезпечити, щоб основні стейкхолдери господарств розуміли очікувані зміни та труднощі, а також довгострокові вигоди органічного агровиробництва та були вмотивовані до змін умов праці.

3. Враховуючі максимальні витрати на початку перходу до органічного агровиробництва в господарствах потрібно приділити увагу пошуку інвеситиційного капіталу на державному або міжнародному рівні щодо розвитку цього виду аграрного бізнесу.

4. За умов недостатнього фінансування перехіного етапу потрібно розглянути можливість диверсифікувати ринкові можливості субєкту господарювання.

5. Потрібно надавати перевагу тим видам аграрного виробництва та можливої подальшої переробки, що дасть змогу отримаити продукцію з збільшеною доданою вартістю для окремих видів продукції господарств.

6. У процесі аграрного виробництва, якщо на підприємстві виробляється не тільки органіча продукцію. то потрібно забезпечити запобігння змішуванню органічних продуктів з неорганічними.

7. Важливим є організація прозорості технологічних процесів через простежуваність i перевірку методів виробництва, транспортування та переробки.

8. Підприємства, зацікавлені в переробці або іншому використанні органічних сільськогосподарських продуктів, повинні враховувати попит споживачів на переробку з низьким рівнем обробітку. Це може стосуватися смаку, справжності, ступеня обробки, занепокоєння щодо конкретних добавок, поживного складу, ступеня зручності, рівня використання енергії та пробігу, а також безпеки харчових продуктів. 
Основними ж етапами для впровадження органічного сільського господарства на теріторії Аніпропетровської області, на нашу думку, є:

1. Набуття загальних знань про органічне сільське господарство щодо технологічних вимог та стандартів. Водночас ці знання потрібно надавати як потенційним виробникам органічної сільськогосподарської продукції, так і їі кінцевим споживачам на регіональному ринку. На цьому етапі вже працюють заклади освіти Аніпропетровського регіону. Зокрема Аніпровським державним аграрно-економічним університетом 30 вересня 2010 р. на шляху подальшої екологізації агровиробництва в Україні спільними зусиллями з Науково-виробничою агрокорпорацією "Степова", за підтримки державних та громадських організацій було відкрито Центр природного землеробства ім. Миколи Руденка. У центрі працюють професори, кандидати наук, аспіранти, молоді вчені, студенти. Співробітники центру створюють методики поступового переходу до принципів природного землеробства, впроваджують ідеї природного землеробства на практиці для отримання органічної сільськогосподарської продукції. Загалом головна мета центру природного землеробства - створити інноваційну систему виробництва та переробки сільськогосподарської продукції, а також систему утилізації відходів. У межах роботи цього центру відбувається популяризація органічного агровиробництва серед студетського співтовариства. В межах навчального процесу в Аніпровському державному аграрно-економічному університеті викладаються навчальні дисципліни для різних спеціальностей і розкривають студентам сутність органічного агровиробництва та його переваги в економічному та екологічному сенсі.

АААЕУ має потужні засоби контролю продукції - науково-дослідний центр екологічного контролю ресурсів агропромислового комплексу: лабораторії якості зерна, лабораторії якості води, це комплекс лабораторій з виявлення залишків гербіцидів, пестицидів, антибіотиків, ГМО та одну 3 найпотужніших лабораторій в Україні - таких лише 3-4 в країні, співпрацює та готовий до подальшої співпраці 3 "органічним агробізнесом" [6].

2. Узагальнення досвіду реальних підприємств, що виробляють органічну сільськогосподарську продукцію. Цей напрям інституціонально забезпечують як навчальні заклади регіону, так і громадські організації. Потенційні виробники органічної сільськогоотспо- дарської продукції мають можливість стати членами громадських організацій України, які сприяють розвитку органічного агробізнесу в Україні та знаходяться під егідою Громадської ради всеукраїнських організацій та об'єднань природоохоронного спрямування при Міністерстві охорони навколишнього природного середовища. Найбільш поширені - це "Федерація органічного руху України", ВГО "Жива планета", ВГО "Клуб органічного землеробства", Органічна Україна (спілка виробників органічних продуктів) та ін.

У межах громадських обєднань їх члени отримують допомогу щодо власного розвику органічних технологій в своїй діяльності. Так, Федерація органічного руху України надає своӥм членам такі послуги: Отримання необхідної інформації про органічне виробництво; Консультації щодо систем, основних вимог, правил ведення органічного господарювання; Отримання знижок на літературу, що видає Федерація; Безкоштовна участь у семінарах, конференціях, круглих столах, що проводить Федерація в Україні з можливістю отримання роздаткового матеріалу;Аопомога в отриманні інформації щодо навчання в Центрах підготовки спеціалістів для органічного агровиробництва; сприяння участі в міжнародних спеціалізованих виставках по органічному сільському господарству, міжнародних семінарах, конференціях, часткове покриття витрат; реклама в виданнях Федерації [11].

3. Оцінка органічного ринку та впровадження ефективного органічного регулювання. Оцінюючі ринок продукції органічного сільськогосподарського виробництва Аніпропетровської області потрібно зазначити що станом на 01.01.2021 р. загальна еількість населення складає 3,15 млн осіб, а середня заробітна плата складає близько 12,0 тис. грн, тобто область має значний потенціал для розвитку органічного землеробства.

Площа сільськогосподарських угідь області складає 2511,5 тис. га, що складає 78,7 \% від загальної площі землекористування [9].

Виходячі з географічного положення потенційний виробних органічної продукції повинен враховувати місце розташування підприємства, можливий кількісний виробничий випуск, якість виробленого продукту, очікувану ціну, транспортні витрати, ділових партнерів та інші аспекти, важливі як для внутрішнього ринку, так і для можливого експорту. Якщо фактори визначені як позитивні і виробник має бажання розвивати власний органічний бізнес, то подальшим кроком буде звернення до сер- 
тифікаційного органу для початку профедення серифікації виробничої діяльності.

Одним з уніфікованих органів стандартизації органічного виробництва на території Аніпропетровської області є ТОВ "Органік Стандарт", яке забезпечує походження та простежуваність потоку органічної продукції, надаючи послуги, які покривають усі сфери виробництва: від контролю вирощування органічних культур - через контроль переробки органічних продуктів - до інспекцій руху продукції в мережі постачання та продаж на місцевому ринку чи здійснення експорту. Підприємство обслуговує представників усіх ланок виробництва та продажу органічних продуктів, ми знижуємо ризики і гарантуємо якість та підвищення продуктивності.

Потрібно зазначити, що повний спектр послуг ТОВ "Органік Стандарт" гарантує якість та безпеку органічних продуктів. Водночас клієнти цього підприємства можуть перевіряти як власне виробництво, так і виробництво контрагентів (за згодою) забезпечення виконання відповідних вимог щодо їхнього виробництва, а також гарантувати якість сировини та допоміжних засобів, отриманих від постачальників [12].

Якщо виробник має бажання долучатися до різних міжнародних ринків, у цьому випадку може знадобитися дотримання декількох різних нормативних актів та стандартів і виробники можуть звернутися до тих органів стандартизації на державному та міжнародному рівні, які будуть задовольняти споживачів продукції підприємства.

Адміністративно-економічне регулювання передбачає заходи адміністративного та економічного характеру, спрямовані на створення умов для функціонування ринкової системи та реалізації соціальних цілей суспільства [10].

Основними системними інституціональними факторами успіху впровадження органічного аграрного виробництва на регіональному рівні та розвитку органічного ринку будуть такі умови:

- обізнаний споживач, який розуміє переваги органічної продукції та знає як їі відрізнити від звичайної продукції;

- спільне бачення та партнерство між бізнес-структурами та державними регіональними інститутами, що адмініструють розвиток органічного сільського господарства на регіональному рівні (передає впевненість інвесторам);

— інтегрований сертифікований ланцюг поставок (забезпечує канали збуту та постійне постачання);
— прозора діяльність підприємства та можливість моментального контролю (створює довіру та підвищує попит);

- добре навчені власники та працівники підприємств, що виробляють органічну сільськогосподарську прродукцію (пропонуючи необхідну технічну підтримку);

- співпраця (інноваційний підхід до розширення ринку, що виявляється ефективним);

- преміальні та/або бонусні виплати (критичний фактор, особливо за конверсії);

— вирішення соціальних проблем (зміцнює довіру та стабілізує співпрацю).

Аля вдосконалення розвитку сільського господарства у Аніпропетровській області та формування вищеобумовленої інституціональної системи пропонуємо заходи адміністративно-економічного регулювання щодо підприємств, які знаходяться в екологічно незабруднені сільськогосподарських та сільських місцевостях регіону та у головних містах області і обумовлюють можливості ефективного розвитку органічного агровиробництва, яке $\epsilon$ важливою передумовою формування продовольчої безпеки країни, економічного зростання національної економіки та підвищення конкурентоспроможності сільського господарства і якості життя сільського населення, зокрема за рахунок популяризації органічного виробництва та вдосконалення інституціонального та інституційного механізмів формуючих чинників в межах підготовки Стратегії розвитку Аніпропетровської області на період 20212027 роки.

Загальна схема заходів адміністративного регулювання представлена на наступному малюнку (див. рис. 3).

Кінцева мета наданих пропозицій передбачає:

- Покращення якості життя всіх мешканців Аніпропетровської області через збільшення в структурі їх харчування якісних та безпечних продуктів вироблених на основі органічних технологій.

- Збільшення вмотивованості агровиробників до виробництві та реалізації органічної сільськогосподарської продукції.

- Збільшення спроможності сільськогосподарських підприємств у виробництві та реалізації органічної продукції.

- Покращення продуктивності та конкурентоспроможності продукції аграрного сектору.

- Покращення стану екосистеми Аніпропетровської області за рахунок поліпшення якісних характеристик грунтів земельних діля- 


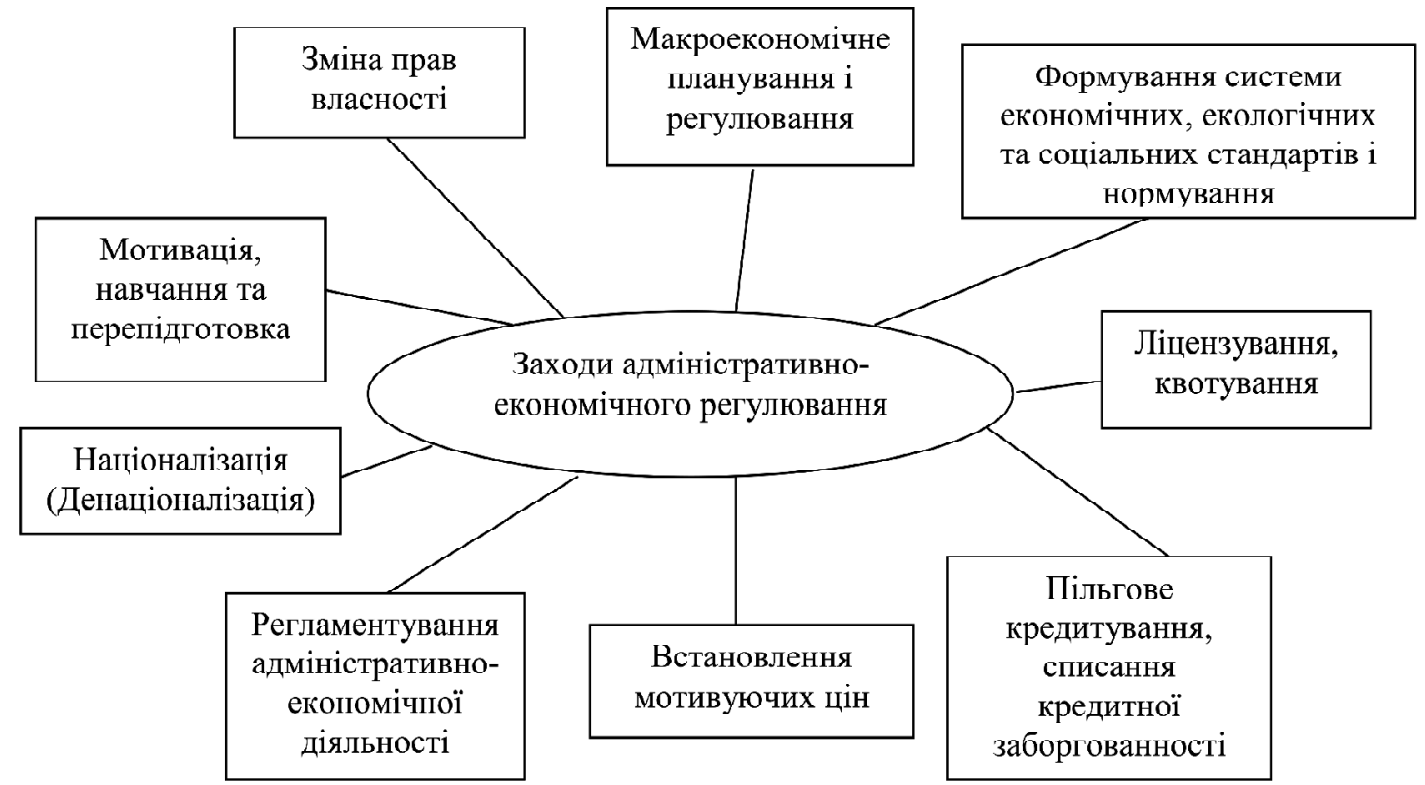

Рис. 3. Заходи адміністративно-економічного регулювання

Ажерело: розроблено автором на основі [2].

нок, що використовуються для виробництва сільськогосподарської продукції і, як наслідок, до покращення якості підземних вод.

- Розвиток галузі органічного бджільництва на території Аніпропетровської області для отримання якісної продукції бджільництва.

На подальшому етапі буде визначено місцевості та потенційних виробників сільськогосподарської органічної продукції та органічної продукції галузі бджільництва на території Аніпропетровської області.

\section{ВИСНОВКИ}

Важливою складовою формування органічного регіонального ринку сільськогосподарської продукції має бути формування зацікавленості у споживанні органічної продукції у населення Аніпропетровської області, тобто формування значного стійкого попиту на цю продукцію.

Визначення мотиваційних інституціональних чинників для підвищення попиту населення Аніпропетровської області на органічну сільськогосподарську продукцію призведе до поліпшення здоров'я мешканців регіону і як наслідок, суттєво покращить якість їх життя. Потрібно зазначити, що для розвитку регіонального ринку органічної продукції потрібний розвиток малих сільськогосподарських підприємств, якими зазвичай є невеликі фермерські господарства, кооперативи. Безумовно, малі сільськогосподарські підприємства не можуть конкурувати з великими виробниками масової сільськогосподарської продукції, зокрема, зерновому та м'ясному секторах. Проте у сфері виробництва органічної продукції саме такі підприємства отримують перевагу перед великими товаровиробниками.

Проте участь малих сільськогосподарських підприємств у цій сфері є обмеженою з декількох причин: не сформованістю культури споживання органічної продукції у містах і браку технічних ресурсів для вирішення завдань у сфері маркетингу та просуванню на ринок органічної сільськогосподарської продукції.

Враховуючи те, що органічна сільськогосподарська продукція - це перспективний сільськогосподарський напрямо, це робить продукцію потенційно прибутковою. Аеякі земельні ділянки області є практично придатними для органічного землеробства, але для того щоб органічне сільське господарство було прибутковою економічною діяльністю, воно потребує розробки фахової інституціональної системи яка буде сприяти ефективному розвитку цього напряму.

Аля ефективного впровадженння органічних теїхнологій у сільське господарство передусім потрібно виявити на регіональному рівні місцевих товаровиробників, включно з тими, які зацікавлені у виробництві органічних продуктів, та розробку схеми надання необхідної мотивації та технічної допомоги для ведення органічного сільського господарства, розробку інституціонального механізму для просування органічної продукції на регіональному та зовнішньому ринках. Потрібно виявити потенціал та інтерес ринку сільськогосподарської продукції в органічних продуктах, а заходи технічної допомоги будуть спрямовані на подолан- 
ня спільних труднощів фермерів у веденні органічного сільського господарства.

Очикується, що після впровадження вищезазначених заходів підвищиться попит населення Аніпропетровської області на органічну сільськогосподарську продукцію та продукцію iii переробки і вмотивованість сільськогоспо-

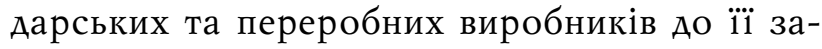
провадження.

\ітература:

1. Act of Sweden on organic production control (SFS 2013:363) from 23 May 2013 // Website Eco-Lex: http://www.ecolex.org

2. Артиш B.I. Особливості органічного агровиробництва в концепції сталого розвитку АПК України / В.І. Артиш // Економіка АПК. - 2012. - № 7. - C. 19-23.

3. Білоткач I.A. Оцінка формальних і неформальних обмежень ринку органічного агровиробництва / Ігор Анатолійович Білоткач. // Агросвіт. - 2017. - № 11. - С. 21-28.

4. Білоткач I. А. Інституціональне забезпечення розвитку інфраструктури ринку органічної сільськогосподарської продукції / Ігор Анатолійович Білоткач. // Інвестиції: практика та досвід. - 2019. - № 3. - С. 12-20.

5. Global organic farming statistics and news. Available at: http://www.organic-world.net.

6. Офіційний сайт Аніпровського державного аграрно-економічного університету // Електронний ресурс, режим доступу: https:/ www.dsau.dp.ua/ua/page/dyalnst.html

7. Заєць В. Законодавче регулювання та державна підтримка [Електронний ресурс]. Режим доступу: https://drive.google. com/drive/ $\mathrm{u} / 3$ /folders/14b HB 8 b mA VDYaY 3tW N J OrukfVCuh_rQ2

8. Саблук П.Т. Розвиток інституцій удосконалення механізму реформування аграрного сектору економіки / П.Т. Саблук // Економіка АПК. - 2010. — № 10. - С. 3-10.

9. Сайт Аержавної служби статистики в Аніпропетровській області [Електронний ресурс]. - Режим доступу: http://www.dneprstat. gov.ua/edrpo/subjects/2021/01/15_01_21/ 3_edrpo_01_20K4.pdf

10. Аупенко Ю.О. Стратегічні напрями розвитку сільського господарства України на період до 2020 року / Ю.О. Аупенко; за ред. Ю.О. Аупенка, В.Я. Месель-Веселяка. - К.: ННЦ "IAE", 2012. - 182 c.

11. Ринок органічної продукції в Україні [Електронний ресурс]. - Режим доступу: http:/ /agro-business.com.ua/agro/podiia/item/9994rynok-orhanichnoi-produktsii-v-ukraini.html
12. Organic Market Development in Ukraine. Available at: https://ukraine.fibl.org/en/uaabout-project.html

\section{References:}

1. Web-site Eco-Lex (2013), "Act of Sweden on organic production control (SFS 2013:363)", available at: http://www.ecolex.org (Accessed 20 March 2021).

2. Artish, V. (2012), "Features of organic agricultural production in the concept of sustainable development of agro-industrial complex of Ukraine", Ekonomika APK, vol. 7, pp. 19-23.

3. Bilotkach, I. (2017), "Evaluation of formal and non-formal limits on the market for organic agricultural production", Agrosvit, vol. 11, pp. $21-28$.

4. Bilotkach, I. (2019), "Institutional development of the development of the infrastructure of the market of organic agricultural products", Investiciï: praktika ta dosvid, vol. 3, pp. 12-20.

5. Organic-World (2021), "Global organic farming statistics and news", Available at: http:// www.organic-world.net (Accessed 20 March 2021).

6. Official site of the Dnieper State Agrarian and Economic University (2021), Available at:: https://www.dsau.dp.ua/ua/page/dyalnst.html (Accessed 20 March 2021).

7. Zaec', V. (2020), "Legislation and state support", Available at: https://drive.google.com/ drive/u/3/folders/14bHB8bmAVDYaY3tWNJCOrukfVCuh_rQ2 (Accessed 20 March 2021).

8. Sabluk, P.T. (2010), "Development institutions to improve the mechanism of reforming the agricultural sector", Ekonomika APK, vol. 10, pp. $3-10$.

9. Website of the State Statistics Service inDnipropetrovsk region (2021), Available at: http:// www.dneprstat.gov.ua/edrpo/subjects/2021/01/ 15_01_21/3_edrpo_01_20K4.pdf(Accessed 20 March $2021)$.

10. Lupenko, Yu.O. (2012), Stratehichni napriamy rozvytku sil's'koho hospodarstva Ukrainy na period do 2020 roku [Strategic directions of development of agriculture of Ukraine for the period till 2020], NNTs "IAE", Kyiv, Ukraine.

11. Kryvenko, O. (2018), "The organic products market in Ukraine", Available at: http://agrobusiness.com.ua/agro/podiia/item/9994-rynokorhanichnoi-produktsii-v-ukraini.html (Accessed $20 \mathrm{March}$ 2021).

12. Organic Market Development in Ukraine (2021), Available at: https://ukraine.fibl.org/en/ ua-about-project.html (Accessed $20 \mathrm{March} 2021$ ). Стаття надійила до редакчї 28.03.2021 p. 
УAK 338.51:[338.43:635]
А. О. Бойко,
к. с.-г. н., Аоцент кафедри економіки та фінансів,
Херсонський Аержавний аграрно-економічний університет, м. Херсон, Україна
ORCID ID: 0000-0003-3699-6906

DOI: $10.32702 / 2306-6792.2021 .7-8.46$

\title{
ЦІНОВА СИТУАЦІЯ ТА ОГАЯА РИНКУ ОВОЧЕВИХ КУАЬТУР "БОРЩОВОГО НАБОРУ"
}

\author{
L. Boiko, \\ $\mathrm{PhD}$ in Agricultural Sciences, Associate Professor, Associate Professor of the Department \\ of Economics and Finance, Kherson State Agrarian and Economic University, Kherson, Ukraine
}

\section{THE PRICE SITUATION AND EXAMINATION OF THE MARKET OF VEGETABLE CROPS OF "BORSHCH SET"}

Овочівництво $є$ ефективною високоприбутковою та конкурентоспроможною галуззю агробізнесу і в останні роки Аосить швидкими темпами нарощує експортний потенціал, але разом з тим зростає імпорт свіжої овочевої продукції. Площа посіву та обсяги виробництва овочевих культур суттєво не змінюються, продукція значною мірою реалізується на внутрішнь ому ринку, тому менш залежна від коливань цін та зовнішніх умов. В агровиробництві основними овочевими культурами відкритого грунту є традиційно овочі "борщового набору": капуста, помідори, морква і буряк столовий та цибуля.

У статті розглянуто виробництво овочевих культур "борщового набору" у господарсвах усіх категорій, підприємствах та господарствах населення. Аосліджено ціни овочевої продукції на найбільших продовольчих ринках "Столичний", "Шувар", "Нежданный". Наголошено на основних причинах низького експорту овочевих культур та збільшення імпортної продукції.

Vegetable farming is an effective highly productive and competitive agribusiness industry. In recent years it has been rapidly increasing export potential, at the same time import of fresh vegetables is rising. The sowing area and volumes of production of vegetable crops do not change considerably, products are mainly sold in the national market, therefore the industry is less dependent on price fluctuations and external conditions. The main factors in a vegetable market are the price which is based on demand and supply; seasonal character of production; the market provision; the number of producers and also product quality. In agricultural production the main garden vegetables are traditional vegetables of "borshch set": cabbage, tomatoes, carrot, beetroot and onion.

The purpose of the paper is to investigate the modern tendencies in the development of vegetable farming, to examine the price situation and the specificity of the market of vegetable crops of "borshch set" in Ukraine.

The paper looks at growing vegetable crops of "borshch set" in all categories of enterprises and farms. It investigates the prices of products in the largest food markets "Stolychnyi", "Shuvar" and "Nezhdannyi". The study emphasizes the main causes of low export of vegetable crops and an increase in import products.

The Ukrainian market of vegetable products is integrating into the global space. It becomes more difficult to export the national vegetables, competition is increasing in the global market, phytosanitary regulations are extremely harsh in the countries of Europe. Therefore, the national producers should change their approach to commodity production. It must be systemic work aimed at applying modern adaptive technologies, using high-quality seeds, investing into processing enterprises, constructing greenhouses and vegetable storehouses for product storage using advanced technologies and marketing. It is also necessary to implement government support of the national producers, to return to a preferential tax regime of VAT and using quotas and restrictions for imported greenhouse vegetables. Such measures will allow the national vegetable farming to be competitive in the global vegetable market.

Ключові слова: овочі відкритого грунту, "борщовий набір", продовольчі ринки, експорт, імпорт, овочесховища, стандарти.

Keywords: garden vegetable, "borshch set", food markets, export, import, oboчecxobuma, standards.

\section{ПОСТАНОВКА ПРОБЛЕМИ}

ОАнією з основних галузей аграрного сектору економіки $є$ овочівництво, яке останніми роками в Україні розвивається досить швидкими темпами. Серед позитивних сторін вирощу- вання овочів є погодні та кліматичні умови, родючі землі, відносно дешева робоча сила, широкий споживчий ринок та здебільшого високі ціни на вирощену продукцію навіть у період сезону збирання врожаю. Галузь овочівництва 
в основному зорієнтована на забезпечення внутрішнього продовольчого ринку та менш залежна від іноземних товарів.

В агровиробництві основними овочевими культурами відкритого грунту є традиційно овочі "борщового набору": капуста, помідори, морква і буряк столовий та цибуля. Загалом агробізнес в овочівництві є досить високоприбутковим напрямом діяльності, що дає змогу швидко окупити інвестиції та забезпечити продовольчу безпеку. Основними чинниками на ринку овочів є ціна, що базується на основі попиту та пропозиції; сезонність виробництва; насиченість ринку; кількість виробників, а також якість продукції.

\section{АНАЛІЗ ОСТАННІХ ДОСЛІДЖЕНЬ І ПУБЛІКАЦІЙ}

Вивченням питань формування та функціонування ринку овочевої продукції займалися ряд вітчизняних вчених, зокрема, Аогоша P.В. [1] розглядає сучасний стан ринку овочів у процесі трансформації економічної системи з урахуванням регіональних особливостей і тенденцій. У статті Андрусяк В. Андрусяк Н. [2] розглянуто основні проблеми ефективного функціонування галузі овочівництва в аспекті економічної безпеки України та шляхи їх вирішення.

У роботі Токарєвої В., Солохи А. [3] преАставлено основні фактори впливу на формування й розвиток ринку екологічно чистої продукції у ринковому середовищі України, про-

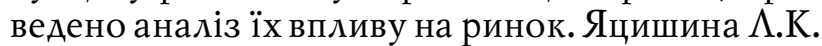
[4] аналізує стан ринку овочів і фруктів в УКраїні, норми споживання цієї продукції, які на сьогодні, за даними Аержавного комітету статистики, є меншими, ніж рекомендовані Міністерством охорони здоров'я України.

Безуглою $\Lambda . С$. [5] здійснено маркетинговий аналіз стану та особливостей плодоовочевого ринку України. Аосліджено та визначено ключову проблему в розвитку виробництва плодоовочевої продукції, проблематику ринку продуктів переробки плодоовочевої сировини. Галат $\Lambda$. М. [6] наголошує, що для ринку овочевої продукції характерна складність та сегментованість через велику різноманітність овочів, які відрізняються термінами та особливостями вирощування, територіальним розміщенням виробництва, способами використанням і зберігання. Однією з важливих особливостей галузі овочівництва є та, що переважна більшість овочів - $85 \%$ виробляються у господарствах населення.

Могильною О.М. та іншими авторами [7] викладено загальну стратегію і пріоритетні напрями наукового забезпечення виробництва малопоширених видів овочів на перспективу. Рудь В.П. [8] у своєму дослідженні характеризує загальну стратегію та пріоритети інституційної підтримки органічного овочівництва в перспективі. Автором встановлено, що інституціональні аспекти органічної овочевої продукції характеризують наявну модель розвитку ринкового механізму як організаційно не ефективну.

Аверчевою Н.О. Крикуновою В.М. [9] досліджено динаміку і структуру виробництва овочів за категоріями виробників та видами продукції, що дозволило виявити основні тренди і фактори впливу на обсяги пропозиції овочевої продукції на ринку. Бойко $\Lambda . О$. [10-12] акцентовано увагу на необхідності впровадження заходів зі зміни існуючої стратегії розвитку овочевої галузі, орієнтованою на підвищення конкурентоспроможності продукції за рахунок інтенсифікації виробництва та переробки, щоб максимально використовувати весь вирощений врожай з доданою вартістю.

У наукових роботах Бойко В.O. [13-16], Квілінського О., Місюка М.В. [16], Танклевської Н.С., Петренко В.С., Карнаушенко А.С. [17] висвітлені питання необхідності підвищення конкурентоспроможності сільськогосподарської продукції та удосконалення функціонування ринків збуту. Водночас виникають питання пов'язані ціновою ситуацією та розвитком ринку овочевих культур, які потребують розгляду та дослідження.

\section{МЕТА ДОСЛІДЖЕННЯ}

Метою статті $€$ аналіз сучасних тенденцій розвитку галузі овочівництва, дослідження цінової ситуації та особливості ринку овочевих культур "борщового набору" в Україні.

\section{ВИКЛАДЕННЯ ОСНОВНОГО МАТЕРІАЛУ ДОСЛІДЖЕННЯ}

Сучасний стан розвитку галузі овочівництва характеризується сталим зростанням обсягів виробництва та значним підвищенням урожайності за рахунок впровадження адаптивних технологій, сучасної техніки, добрив, засобів захисту рослин та більш якісного насіння. У 2019 р. загальний обсяг виробництва усіх видів овочів наблизився до $10 \mathrm{млн} \mathrm{тонн}$ (табл.1), що робить цю галузь однією з найбільш ефективних з точки зору інтенсивного використання земельних ресурсів.

Плодоовочевий бізнес в Україні в основному представлений малими та середніми фермерськими господарствами, або домогосподарствами, які характеризуються невеликими об- 
сягами виробництва та реалізації. Попри високу трудомісткість виробництва, на сьогодні майже 92,5\% усіх посівних площ зайнятих під овочівництвом відкритого грунту, зосереджено у господарствах населення, тоді як частка підприємств під ними становить лише 7,5\%. Aле позитивні тенденції виробництва овочів у малих формах господарювання можуть загальмуватись через відсутність каналів реалізації цієї продукції та обмеженою кількістю сховищ для ¥ї тривалого зберігання. Саме тому близько $80 \%$ плодоовочевої продукції в Україні збувають через базари та місця стихійної торгівлі. Ті ж 20\%, які реалізовуються через супермаркети, зазвичай вирощуються середніми підприємствами, які можуть забезпечити безперебійнє постачання та відповідність продукції необхідним стандартам. У перспективі великотоварне виробництво збільшуватиме свою частку в загальних обсягах вирощеної продукції [19].

У Европі вже переконалися, що дрібнотоварні господарства мають перспективи для розвитку, лише об'єднавшись у сільськогосподарські обслуговуючі кооперативи з маркетинговими та юридичними службами, які мають усі можливості для захисту своїх інтересів і вирішення наболілих проблем. В Україні останнім часом також з'являються подібні об'єднання. На Херсонщині, наприклад, уже функціонує Асоціація сільгоспвиробників Таврії, фахівці якої вивчають й аналізують плани і можливості та діяльність сільських господарств, щоб уникнути перевиробництва одних видів продукції і дефіциту інших. Тому великі врожаї перестають бути самоціллю для українських овочівників. Щоб міцно вкорінитися на вітчизняному ринку та відвойовувати зарубіжні, доведеться не просто збільшувати площі під овочеві культури, а й опановувати нові стандарти самої культури овочівництва, спираючись не лише на давні традиції, а й враховуючи високі вимоги сучасного споживача [20].

Аослідження функцій попиту на овочі показує, що існує достатній зв'язок між споживанням овочів і доходами населення, коефіцієнт еластичності показує, що у разі зростання середньомісячної заробітної плати на 1\% споживання цього продукту зростає на 1,43%. Майже всі овочі "борщового набору" із січня

\section{Таблиця 2. Ціни на овочеву продукцію "борщового набору" (грн за кг), лютий 2021 р.}

\begin{tabular}{|l|l|l|l|}
\hline & $\begin{array}{c}\text { Ринок } \\
\text { «Столичний» }\end{array}$ & $\begin{array}{c}\text { Ринок } \\
\text { «Шувар» }\end{array}$ & $\begin{array}{c}\text { Ринок } \\
\text { «Нежданный» }\end{array}$ \\
\hline $\begin{array}{l}\text { Капуста } \\
\text { білокачанна }\end{array}$ & 4,00 & 4,20 & 3,50 \\
\hline Цибуля ріпчаста & 3,80 & 4,00 & 3,75 \\
\hline Буряк столовий & 4,50 & 4,80 & 4,50 \\
\hline Морква & 5,50 & 4,00 & 4,75 \\
\hline Картопля & 9,00 & 8,50 & 9,50 \\
\hline
\end{tabular}

Ажерело: [21].

2020 р. по січень 2021 р. подешевшали: зокрема картопля - на 15,2\%, ріпчаста цибуля - на $38,5 \%$; буряк - на $1,4 \%$; капуста - на $14,9 \%$. \ише морква за вказаний період подорожчала на 3,1\% (табл. 2).

Фермери продають майже всі складові "борщового набору" за найнижчими цінами за останні 3 роки. Аля покупців це безперечно плюс, особливо, якщо згадати, що рік тому в цей час картопля коштувала по 10-12 грн/кг, а сьогодні - від 5,5 грн/кг. Проте якщо такі низькі ціни будуть зберігатись, то наступного року можемо отримати протилежний ефект.

Через низьку ціну на отриманий врожай аграрії вимушені будуть зменшити посівні площі овочів у наступному сезоні. А це може привести до зменшення валового збору, підвищення ціни та ймовірна поява імпорту [22].

Відіграє свою роль у цьому процесі і брак ефективного планування, загалом овочі є дуже ризикованою категорією культур. Аля належного задоволення потреб ринку ризик перевиробництва несе не менше загроз ніж ризик недовиробництва. Щодо одноосібних господарників, то переважна їх більшість взагалі не замислюється над тим, як сформувати товарні партії продукції, тоді як у країнах Євросоюзу виробництво овочів чітко планують і прогнозують. Наприклад, у Гол- 


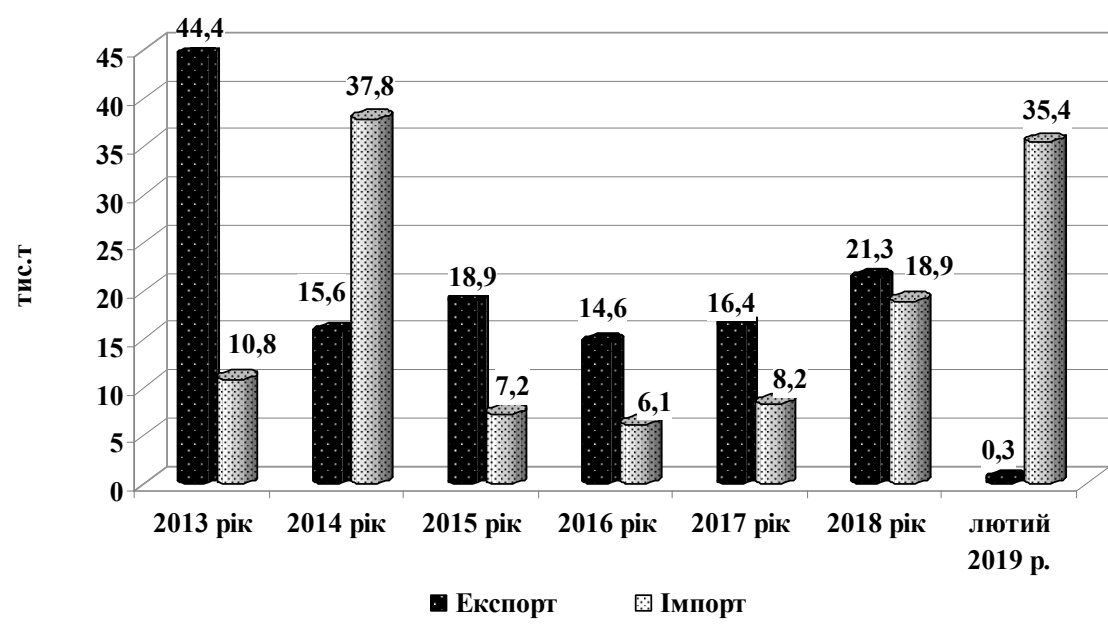

Рис. 1. Експорт - імпорт цибулі, тис. т

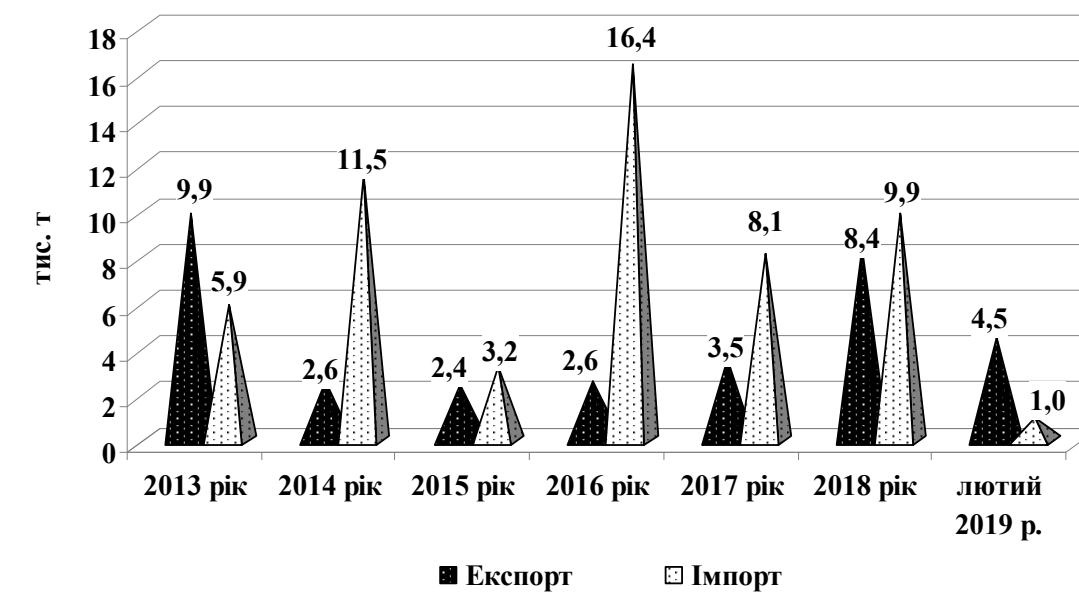

Рис. 2. Експорт - імпорт капусти, тис. т
Ажерело: [23].

ландії фермер перебуває під постійним контролем і він не має права висадити жодного зайвого куща городини. Таким чином сільгоспвиробники утримують ціни на свою продукцію, що дає змогу їм працювати з прибутком [23].

Україна щороку нарощує свою зовнішньоекономічну спроможність на ринку овочів, вона $€$ одним із найбільших виробників овочів і фруктів у Східній Європі, але одночасно ринок наповнюється імпортною овочевою продукцією. У 2016 році Україна імпортувала свіжих овочів і фруктів на 443 млн євро, у 2019 р. уже на $550 \mathrm{mлн,} \mathrm{а} \mathrm{експортувала} \mathrm{відповідно}$ на 38 млн і 65 млн. Торговельний дефіцит при цьому збільшився з 405 млн до 485 млн євро. У 2020 р. експорт свіжих овочів упав 365 тис. тонн до 55 тис. тонн. Збільшилися лише продажі цибулі (з 14 до 20 тис. тонн). Імпорт овочів зріс 3 89 тис. до 120 тис. тонн. У топ-трійку товарних позицій входять томати, цибуля та огірки [24].

Аослідження ринку овочівництва свідчить про те, що більша частина овочів виробляється
Аля споживання на внутрішні ринки, а на міжнародному ринку продається лише до $5 \%$ світового виробництва продукту. На рисунку 1 представлена динаміка експорту-імпорту цибулі в Україні за 2013-2019 рр. Найвищі обсяги експорту цього товару, завдяки рекордному врожаю та невисоким цінам, відмічено у 2013 р. (44,4 тис. т). У 2014 р. виробники значно зменшили посівні площі культури, також додались аномальні погодні умови, які знизили врожайність цибулі і це призвело до імпорту продукції в обсязі 37,8 тис. т. Аналогічна ситуація спостерігалась і у 2019 р. коли за перші два місяці в Україну було завезено 35,4 тис. т цибулі - більше, ніж в Німеччину, традиційного імпортера цього овочу. Основними постачальниками цибулі до України були Узбекистан і Казахстан, на які припало $86 \%$ всього імпорту.

Встановлено, що останні два маркетингових роки ціни на цибулю трималися на високому рівні, зазвичай вони коливаються через сезон, але 2019/2020 МР - зберігалися високими. У 2019 р. аграрії наростили площі під цибулею, також зайшли на ринок і зацікавились кон'юнктурою нові виробники. Ці фактори разом призвели до збільшення площ посіву, з використанням якісного насіннєвого матеріалу. У результаті 2019 р. виробники отримали найвищий урожай цибулі за останні п'ять сезонів. Це призвело до тимчасового зниження цін: до 1 березня 2020 р. трималася ціна близько 6 грн/кг. Зокрема, відновленню цін допомогла інформація в ЗМІ про користь цибулі для профілактики різних захворювань та можливого захисту від вірусів на тлі пандемії COVID-19.

Співвідношення імпорту до експорту іншого овочу "борщового набору" - капусти за період з 2013-2019 рр. відображено на рисунку 2. 32014 р. імпорт цього овочу переважає над експортом. У 2015 р. Україна вперше почала імпортувати овочі "борщового набору". Експерти стверджують, що така необхідність виникла у зв'язку з падінням в Україні врожайності найпопулярніших овочів на $10-13 \%$ в залежності від культури, а також площ під ними приблизно на $5 \%$. 
На вирощуванні капусти виробник за один сезон може сильно як виграти, так і програти. Сезон 2019 р. завдав удару виробникам через низькі ціни, особливо в кінці сезону. Тому у 2020 р. аграрії не збільшували площі під цією культурою, гуртові осінні закупівельні ціни на капусту останні чотири роки утримуються на рівні не нижче 5 грн кг.

Коренеплоди з "борщового набору", такі як буряк та морква, самі нецікаві для експорту культури. Тому з 2015 р. імпорт переважає над експортом (рис. 3). У 2016 р. найбільш суттєво зріс імпорт моркви та столового буряка - у 34 рази - до 5,8 тис. т з 169 т роком

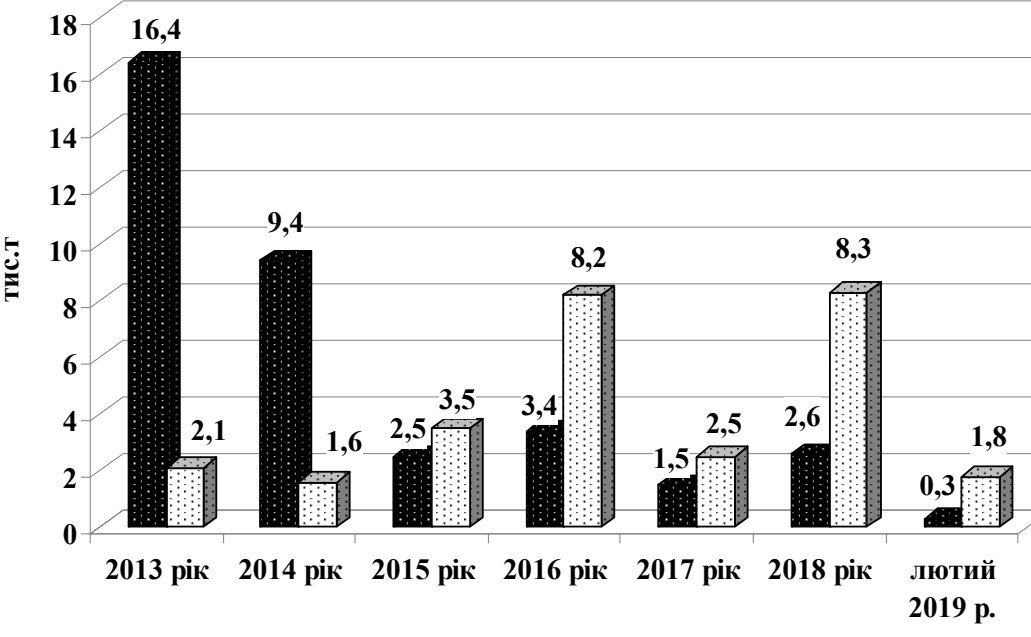

[. Експорт

Рис. 3. Експорт - імпорт моркви та столових буряків, тис. т Ажерело: [23]. раніше. У 4 рази збільшився обсяг ввезеної картоплі, до 2,1 тис. т з 513 т, майже вдвічі - капусти, до 1,1 тис. т. 3584 т, і на чверть - цибулі, до 2,2 тис. т 3 1,8 тис. т. Водночас вартість "борщового набору" на кінець першого кварталу 2016 р. порівняно з аналогічним періодом 2015 р. зросла майже в півтора раза - до 43,68 грн 3 29,48 грн [25].

2019/2020 рр. МР став для виробників моркви та столових буряків розчаруванням через низькі ціни на цей товар. Основна причина низького цінового тренда в сегменті коренеплодів це збільшення обсягів пропозиції на ринку на тлі стриманого попиту. Зазвичай впродовж березня-квітня в українських наявних сховищах вже вичерпуються запаси продукції високої якості Аля формування значних оптових партій. У 2020 р. навіть на кінець весни в овочесховищах зберігалося чимало високотоварної продукції, ціна на яку не перевищувала 5 грн/кг. Ао столового буряку професійні виробники виявляють менший інтерес, бо це продукт внутрішнього українського ринку, який тримається на кулінарній традиції і на зовнішній ринок не постачається.

\section{ВИСНОВКИ З ПРОВЕДЕНОГО ДОСЛІДЖЕННЯ}

Український ринок плодоовочевої продукції інтегрується у міжнародний простір. Експортувати вітчизняні овочі дедалі складніше, конкуренція на світовому ринку посилюється, фітосанітарні норми у країнах Європи надто жорсткі. Тому вітчизняним виробникам необхідно змінювати підхід до виробництва товарного продукту. Це повинна бути системна робота у напрямі сучасних адаптивних технологій, використанні якісного насіннєвого мате-

ріалу, інвестуванні коштів у підприємства доробки, будівництво теплиць за новітніми технологіями, овочесховищ для зберігання продукції та її маркетинг. Також впровадження державної підтримки вітчизняних виробників, повернення пільгового режиму оподаткування ПАВ і введення квот та обмежень на імпорт тепличних овочів. Такі заходи будуть сприяти вітчизняному овочівництві бути конкурентоспроможними на світовому овочевому ринку.

\section{$\Lambda$ ітература:}

1. Аогоша Р.В. Трансформації ринку овочів в Україні. Економіка. Фінанси. Менеджмент: актуальні питання науки і практики. 2016. Вип. 3 (8). С. 55-67.

2. Анарусяк В., Анарусяк Н. Основні проблеми ефективного функціонування галузі овочівництва в аспекті економічної безпеки. 3бірник наукових праць ЧАТУ. Серія: Економічні науки. Вип. 38. Ч. 1. 2014. С. 97-102.

3. Токарева В. \& Солоха A. (2021). Факторний аналіз державного управління розвитком ринку екологічно чистої продукції в Україні, Scientific Collection "InterConf", (41): with the Proceedings of the 7th International Scientific and Practical Conference "Scientific Horizon in The Context of Social Crises" (Febryary 6-8, 2021) at Tokyo, Japan. C. 158-167. URL: https://ojs.ukrlogos.in.ua/index.php/interconf/article/view/8614

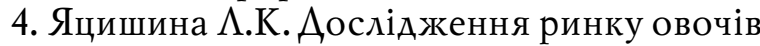
і фруктів в Україні. Економіка та держава. 2019. № 2. C. 105 -109. doi: 10.32702/23066806.2019.2.105

5. Безугла А.С. (2020). Маркетинговий аналіз плодоовочевого ринку в контексті виробництва біологічно цінних харчових про- 
дуктів. Економічний простір, (154), 31-35. URL: https://doi.org/10.32782/2224-6282/154-5

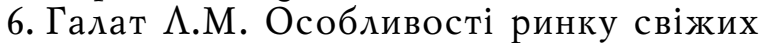
овочів в Україні. Агросвіт. 2019. № 11. С. 3544. DOI: 10.32702/2306-6792.2019.11.35

7. Могильна О.М., Рудь В.П., Хареба О.В.,

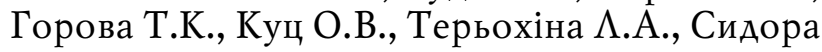
B.B. Пріоритетні напрями наукового забезпечення виробництва малопоширених видів овочевих рослин в Україні. Овочівництво і баштанництво. Випуск 64, 2018. С. $75-88$.

8. Рудь В.П. Інституційне забезпечення розвитку органічного овочівництва. Інтелект XX.I № 6. 2016. С. 124-134.

9. Крикунова В.М., Аверчева Н.О. Пріоритети та особливості формування пропозиції на ринку продукції овочівництва в Україні. Науковий вісник Ужгородського національного університету. Серія: Міжнародні економічні відносини та світове господарство. Вип. 29. 2020. С. 84-93.

10. Бойко $\Lambda . О$. Сучасні тенденції розвитку овочевої галузі в умовах євроінтеграції України. Агросвіт. 2020. № 6. С. 69-76. doi: 10.32702/ 2306-6792.2020.6.69

11. Бойко А.О. Пріоритети розвитку підприємництва зі створенням інноваційних продуктів. Агросвіт. 2020. № 15. С. 41-47. doi: 10.32702/2306-6792.2020.15.41

12. Морозов Р.В., Бойко М.О. Економічна роль біржової торгівлі та сучасні тенденції їі розвитку. Агросвіт. 2018. № 9. С. 3-8.

13. Бойко В. \& Бойко $\Lambda$. (2021). Прогнозування та шляхи ефективного розвитку галузі овочівництва у південному регіоні. Фінансовий простір, (4(40), 53-61. https://doi.org/10.18371/ fp.4(40).2020.221681

14. Бойко В.О., Бойко М.О. Сучасні підходи до визначення поняття "конкурентоспроможність аграрних підприємств". Фінансовий простір. 2019. № 3 (35). C. 23-31. DOI:https:// doi.org/10.18371/fp.3(35).2019.190153

15. Бойко В.О. Аіагностика бізнес-середовища та стратегії підвищення конкурентоспроможності аграрних підприємств: автореф. дис. на здобуття наук. ступеня канд. екон. наук: 08.00.04. Миколаїв, 2014. 22 с.

16. Boiko V., Kwilinski A., Misiuk M. \& Boiko L. (2019). Competitive advantages of wholesale markets of agricultural products as a type of entrepreneurial activity: the experience of Ukraine and Poland. Economic Annals-XXI. 175 (1-2). P. 68-72. doi: https://doi.org/10.21003/ea.V175-12

17. Tanklevska N., Petrenko V., Karnaushenko A., Melnykova K. World corn market: analysis, trends and prospects of its deep processing.
Agricultural and Resource Economics. 2020. Vol. 6. No. 3. Pp. 96-111. URL: https://arejournal.com/index.php/are/article/view/339/253

18. Аержавна служба статистики. URL: http://www.ukrstat.gov.ua

19. АПК в Україні: аналіз впливу кризи та карантину. URL: https://pro-consulting.ua/ua/ pressroom/apk-v-ukraine-analiz-vliyaniyakrizisa-i-karantina

20. АНА ІІЗ РИНКУ ОВОЧІВ УКРАЇНИ 2017-1 ПІВР. 2020 POКУ. URL: https://proconsulting.ua/ua/issledovanie-rynka/analizrynka-ovoshej-ukrainy-2017-1-pol-2020-goda

21. Біржовий вісник Київської агропромислової біржі "Київагропромбіржа". URL: http:/ /www.visnik.kiev.ua/ukr/zurnal/visnik.pdf

22. Борщовий набір овочів сьогодні найдешевший за минулі 3 роки. URL: https:// www.agroone.info/agronews/borshhovij-nabirovochiv-sogodni-najdeshevshij-za-minuli-3-roki/

23. Кілограм капусти за долар: що очікує українських споживачів. URL: https://uagra.com.ua/uk/statti/19-kilohram-kapusty-za-dolarshcho-ochikuie-ukrainskykh-spozhyvachiv1

24. Україну назвали одним із провідних виробників овочів і фруктів у Європі. URL: https:/ /www.ukrinform.ua/rubric-economy/2872649ukrainu-nazvali-odnim-iz-providnih-virobnikivovociv-i-fruktiv-u-evropi.html

25. Імпорт до України овочів борщового набору зріс майже у 7 разів. URL: https:// www.unian.ua/economics/agro/1327137-importdo-ukrajini-ovochiv-borschovogo-naboru-zrismayje-u-7-raziv.html

\section{References:}

1. Lohosha, R.V. (2016), "Transformations of the vegetable market in Ukraine", Economics. Finance, Management: topical issues of science and practice, vol. $3 / 8$, pp. 55-67.

2. Andrusiak, V. and Andrusiak, N. (2014), "The main problems of the effective functioning of vegetable farming in the aspect of economic security", The collection of scientific papers of ChSTU. Series: Economic sciences, vol. (38) 1, pp. $97-102$.

3. Tokareva, V. and Silokha, D. (2021), "Factor analysis of government management of the market of environmentally friendly products in Ukraine", Scientific Collection "InterConf", (41): with the Proceedings of the 7 th International Scientific and Practical Conference "Scientific Horizon in The Context of Social Crises", Tokyo, Japan, Febryary 6-8, pp. 158-157, available at: https://ojs.ukrlogos.in.ua/index.php/interconf/article/view/ 8614 (Accessed 16 March 2021). 
4. Yatsyshina, L. (2019), "Market research on fruits and vegetables in Ukraine", Ekonomika ta derzhava, vol. 2, pp. 105-109. DOI: 10.32702/23066806.2019.2.105

5. Bezuhla, L. S. (2020), "Marketing analysis of the vegetable market in the context of manufacturing biologically valuable food products", Economic space, (154), pp. 31-35, available at: https://doi.org/10.32782/2224-6282/154-5

6. Galat, L. (2019), "Perculiarities of market of fresh vegetables in Ukraine", Agrosvit, vol. 11, pp. 35-44. DOI: 10.32702/2306-6792.2019.11.35

7. Mohylna, O. M. Rud, V. P. Khareba, O. V. Horova, T. K. Kuts, O. V. Terokhina, L. A. and Sydora, V. V. (2018), "Major trends in scientific support for production of limited species of vegetable plants in Ukraine", Vegetable farming and melon production, vol. 64, pp. 75-88.

8. Rud, V.P. (2016), "Institutional support for the development of organic vegetable farming", Intelligence XX.I, vol. 6, pp. 124-134.

9. Krykunova, V.M. and Avercheva, N.O. (2020), "Priorities and specifics of the supply formation at the market of vegetable products in Ukraine", Scientific bulletin of Uzhorod National University. Series: International economic relations and the global econo, vol. 29, pp. 84-93.

10. Boiko, L. (2020), "Modern tendencies in the development of vegetable industry under conditions of Ukraine's euro-integration", Agrosvit, vol. 6, pp. 69-76. DOI:10.32702/23066792.2020.6.69

11. Boiko, L. (2020), "Priorities of entrepreneurial development with the creation of innovative products", Agrosvit, vol. 15, pp. 41-47. DOI:10.32702/2306-6792.2020.15.41

12. Morozov, R. and Boiko, L. (2018), "The economic role of exchange trade and modern tendencies of its development", Agrosvit, vol. 9, pp. 3-8.

13. Boiko, V. and Boiko, L. (2021), "Forecasting and ways of efficient development of the vegetable production industry in the southern region", Financial space, vol. 4 (40), pp. 53-61. https:// doi.org/10.18371/fp.4(40).2020.221681

14. Boiko, V. and Boiko, L. (2019), "Modern approaches to defining the concept "competitiveness of agrarian enterprises", Financial space, vol. 3 (35), pp. 23-31. https://doi.org/10.18371/ fp.3(35).2019.190153

15. Boiko, V.O. (2014), "Diagnostics of a business-environment and strategies of increasing competitiveness of agrarian enterprises: an author's summary of the dissertation for the scientific degree of a candidate of economic sciences", Ph.D. Mykolaiv, 22, Ukraine.
16. Boiko, V. Kwilinski, A. Misiuk, M. and Boiko, L. (2019), "Competitive advantages of wholesale markets of agricultural products as a type of entrepreneurial activity: the experience of Ukraine and Poland", Economic Annals-XXI, vol. 175 (1-2), pp. 68-72. DOI: https://doi.org/ 10.21003/ea.V175-12

17. Tanklevska, N. Petrenko, V. Karnaushenko, A. and Melnykova, K. (2020), "World corn market: analysis, trends and prospects of its deep processing". Agricultural and Resource Economics, vol. 6, no. 3, pp. 96-111, available at: http:/ /arejournal.com (Accessed 16 March 2021).

18. State statistics service (2021), available at: http://www.ukrstat.gov.ua (Accessed 16 March 2021).

19. Pro-Consulting (2020), "AIC in Ukraine: analysis of the impact of crisis and quarantine", available at: https://pro-consulting.ua/ua/ pressroom/apk-v-ukraine-analiz-vliyaniyakrizisa-i-karantina (Accessed 18 March 2021).

20. Pro-Consulting (2020), "Analysis of the vegetable market in Ukraine 2017 - the 1st halfyear 2020", available at: https://pro-consulting.ua/ua/issledovanie-rynka/analiz-rynkaovoshej-ukrainy-2017-1-pol-2020-goda (Accessed 18 March 2021).

21. The exchange bulletin of Kyiv agroindustrial stock exchange "Kyivahroprombirzha" (2021), available at: http://www.visnik.kiev.ua/ ukr/zurnal/visnik.pdf (Accessed 18 March 2021).

22. AgroONE (2020), "Borshch set of vegetables has been the cheapest in comparison for the past 3 years", available at: https://www.agroone.info/agronews/borshhovij-nabir-ovochivsogodni-najdeshevshij-za-minuli-3-roki/ (Accessed 20 March 2021).

23. Ukrainian Agrarian Association (2019), "Kilogram of cabbage costs a dollar: what Ukrainian consumers should expect", available at: https://uagra.com.ua/uk/statti/19-kilohramkapusty-za-dolar-shcho-ochikuie-ukrainskykhspozhyvachiv1 (Accessed 20 March 2021).

24. Ukrinform (2020), "Ukraine has been called one of the most leading vegetable and fruit producers in Europe", available at:https://www.ukrinform.ua/ rubric-economy/2872649-ukrainu-nazvali-odnimiz-providnih-virobnikiv-ovociv-i-fruktiv-uevropi.html (Accessed 20 March 2021).

25. UNIAN (2021), "Import of the vegetables of borshch set to Ukraine has increased almost 7 times", available at: https://www.unian.ua/ economics/agro/1327137-import-do-ukrajiniovochiv-borschovogo-naboru-zris-mayje-u-7raziv.html (Accessed 20 March 2021).

Стаття надійшла до редакиії 26.03.2021 p. 
УАK 331.52.001.8

\title{
С. В. Герчанівська,
}

к. е. н., доцент кафедри обліку і аудиту, Відокремлений підрозділ Національного університету біоресурсів і природокористування України "Бережанський агротехнічний інститут"

ORCID ID: 0000-0002-7908-1397

H. I. Петренко,

А. е. н., професор кафедри обліку і аудиту, Відокремлений підрозділ

Національного університету біоресурсів і природокористування України

"Бережанський агротехнічний інститут"

ORCID ID: 0000-0001-9583-6350

O. B. Качмар,

к. е. н., Аоцент кафедри обліку і аудиту, Відокремлений підрозділ

Національного університету біоресурсів і природокористування України

"Бережанський агротехнічний інститут"

ORCID ID: 0000-0002-9936-8707

DOI: $10.32702 / 2306-6792.2021 .7-8.53$

\section{СУТНІСТЬ І ХАРАКТЕРИСТИКА ОСНОВНИХ ПОНЯТЬ РИНКУ ПРАЦІ В СОЦІААЬНО-ЕКОНОМІЧНІЙ СИСТЕМІ}

\author{
S. Herchanivska, \\ $\mathrm{PhD}$ in Economics, Associate Professor of the Department of Accounting and Audit, \\ SS NULES of Ukraine "Berezhany Agrotechnical Institute" \\ N. Petrenko, \\ Doctor of Economic Siences, Professor of the Department of Accounting and Audit, \\ SS NULES of Ukraine "Berezhany Agrotechnical Institute" \\ O. Kachmar, \\ $\mathrm{PhD}$ in Economics, Associate Professor of the Department of Accounting and Audit, \\ SS NULES of Ukraine "Berezhany Agrotechnical Institute"
}

\section{ESSENCE AND CHARACTERISTICS OF THE BASIC CONCEPTS OF THE LABOR MARKET IN THE SOCIO-ECONOMIC SYSTEM}

У статті висвітлено наукові підходи до визначення ринку праці. Аано оцінку та проаналізовано погляди сучасних учених на зміст цього поняття. Визначено спільні та відмінні характеристики між термінами "ринок робочої сили" та "ринок праці". Узагальнено й уточнено поняття "робоча сила", "праця". Сформульовано власний підхіА до визначення змісту категорії "ринок праці". Розкрито склад і структуру ринку праці. Показано, що ринок праці являє собою механізм погодження інтересів роботодавців, тому основними його елементами є попит, пропозиція робочої сили, іï ціна та вартість. Визначено, що в сучасному товарному виробництві заробітна плата виступає як ціна, за якою найманий працівник продає свою робочу силу.Аоведено взаємозв'язок і взаємозалежність функцій ринку праці, які включають всі аспекти його функціонування. Обгрунтовано, що ефективний розвиток ринку праці реалізовується через теоретико-методологічну площину, в центрі уваги якої чільне місце відводиться понятійному апарату.

The article highlights scientific approaches to defining the labor market. The views of modern scientists on the content of this concept are evaluated and analyzed.

It is shown that at the present stage the labor market is the main indicator of the state of economic and social development, and the balance between supply and demand on it indicates the stability of the country's development. It should be noted that the issues of the labor market in the economic literature are given considerable attention, however, there are a number of differences in the conceptual apparatus. Based on the study of the views of various scientists, we consider it economically acceptable to consider the concepts of "labor market" and "market of the labor force" as synonyms. It is concluded that defining the concept of "labor market" should be based on the requirements of a 
comprehensive, systematic and dialectical approach using the methodology of socio-economic analysis. Currently, there is no consensus among scientists to determine the nature of the labor market. Different interpretations of the labor market reflect its uncertainty and versatility. These views do not contradict each other; they can be considered as complementary. The own approach to definition of the maintenance of a category "labor market" is formulated.

The composition and structure of the labor market are revealed. It is shown that the labor market is a mechanism for reconciling the interests of employers, so its main elements are demand, supply of labor, its price and cost. Demand in this market is determined by the number and quality of vacancies (vacancies), as well as employed, but those that for one reason or another currently need to replace employees. The proposal characterizes the number and structure of the population that offers its ability to work and receives a fund of life benefits. It is determined that in modern commodity production wages act as the price at which an employee sells his labor. The interconnection and interdependence of labor market functions, which include all aspects of its functioning, is proved. It is substantiated that the effective development of the labor market is realized through the theoretical and methodological plane, in the focus of which a prominent place is given to the conceptual apparatus.

Ключові слова: ринок прачі, ринок робочої сили, попит і пропозичіл робочої сили, чіна прачі, Bapmicms npayi.

Key words: labor market, market of the labor force, supply and demand for the labor force, labor prices, labor costs.

\section{ПОСТАНОВКА ПРОБЛЕМИ}

Сучасні умови в сфері господарювання, що формуються під впливом реформ, вагомо впливають на зайнятість населення як одного з основних індикаторів формування рівня життя населення та одночасно економічної могутності держави. Адже саме людина є основним елементом виробничого процесу, а свою функцію чинника економічного розвитку населення виконує шляхом включення фізичних, інтелектуальних та моральних сил у суспільний господарський процес.

Ринок праці виступає основним індикатором стану сучасної економіки, відображає рівень розвитку суспільства, а рівновага між попитом та пропозицією на ньому свідчить про стабільність економічного розвитку країни. Через такі фактори як виробництво, споживання, стимулювання інвестиційного процесу ринок праці впливає на інші ринки, в той же час функціонально з ними пов'язаний. На відміну від них такий ринок має не лише ресурсний, товарний характер, але й зумовлює набагато більше економічних та соціальних проблем (інфляція, безробіття, бідність і т. А.), тому потребує особливої уваги з боку держави. Як невід'ємна складова ринкового господарства ринок праці охоплює всі форми власності, галузі національної економіки, види діяльності, розподіляючи працю людей у відповідності з потребами суспільства.

На ринку праці відбувається взаємозв' язок між робітниками та роботодавцями, оскільки він забезпечує підприємства кваліфікованими працівниками, що відповідає їхнім вимогам, 3 однієї сторони, а з іншої-дає можливість працівникам вибирати таку роботу, що б найбільш повно задовольняла їх потреби та нужди.

\section{АНАЛІЗ ОСТАННІХ ДОСЛІДЖЕНЬ ТА ПУБЛІКАЦІЙ}

Питанням ринку праці завжди приділялось багато уваги. В науковій літературі нині є ряд дискусійних питань та відсутня єдина точка зору щодо формулювання сутності і визначення особливостей ринку праці. Широкий діапазон визначень ринку праці інтерпретований такими авторами: В.С. Васильченко, М.А. Головко, І.Ф. Гнибіденко, А.Г. Горілий, А.М. Колот, Ю.М. Краснов, Е.М. Аібанова, Ю.М. Маршавін, Г.І. Мімандусова, В.П. Пастухов, М.І. Синюченко, М.В. Шаленко та іншими. У їх наукових працях здійснено детальний аналіз умов розвитку ринку праці, факторів впливу на основні його показники, обгрунтовано необхідність державного регулювання зайнятості. Попри достатню кількість наукових напрацювань, подальших досліджень потребує вивчення особливостей функціонування ринку праці з урахуванням сучасних тенденцій його розвитку.

\section{META CTATTI}

Метою статті $\epsilon$ наукове обгрунтування теоретичних положень ринку праці, його особливостей, структури, складу, функцій, основних аспектів функціонування і розвитку.

\section{ВИКЛАД ОСНОВНОГО МАТЕРІАЛУ}

Поняття "ринок праці" завжди привертало увагу вчених і практиків у галузі філософії, соціології, психології, економіки. Аослідники розглядали й аналізували ринок праці крізь призму власних поглядів, переконань, об'єктів дослідження. Саме цим і пояснюється цілком природне різноманіття тлумачень даного поняття, а погляди багатьох дослідників цієї сфе- 
ри можна розглядати як взаємодоповнюючі, такі що не суперечать один одному.

Зокрема, розходяться думки вчених відносно термінології "ринок робочої сили" та "ринок праці". А. Калініна стверджує, що ці поняття різняться тим, що робоча сила являє собою потенційну здатність до праці, а праця - функціонуючу здатність. Тому поняття "ринок робочої сили" дещо ширше, так як охоплює відносини не лише щодо зайнятих, а й незайнятих громадян, які активно шукають роботу, тобто зайнятих і безробітних [12, с. 9]. А. Ачкасов вважає, що оскільки праця не є товаром на ринку, то ринок праці насправдіє ринком робочої сили [1, с. 159].

Цієї ж думки дотримується В. Герасимчук, але зазначає, що перехід ринку робочої сили у ринок праці відбувається не в процесі ринкових відносин, які є умовою такого переходу, а в процесі відтворення робочої сили [4, с. 11]. Ми розділяємо ці погляди та вважаємо економічно прийнятним розглядати поняття "ринок праці" та "ринок робочої сили" як синоніми.

В. Петюх, віддаючи перевагу поняттю "ринок праці", вважає його дещо умовним та спрощеним. На його думку, правильніше було б вживати термін "ринкові відносини у сфері праці" чи "ринкові відносини у сфері зайнятості населення найманою працею", поскільки ринок праці, на відміну від інших видів ринків, не має єдиного визначеного товару (хоча здебільшого вважають, що це є робоча сила) [12, с. 15].

Цікавою, на наш погляд, є думка деяких вчених про те, що ринок праці складається з ринку робочої сили і ринку робочих місць, тобто перший виражає пропозицію, а другий - попит, як дві основні характеристики ринку. ВіАповідно взаємодія між попитом і пропозицією робочої сили визначає механізм функціонування ринку, а співвідношення між ними формує ціну праці [4, с. 12; 3, с. 12]. Ми погоджуємось із поглядами В. Петюха, який вважає, що ринок робочих місць $є$ відносно уособленим типом ринку, що пов'язаний з іншими типами, в тому числі й ринком праці. Проте в сучасних умовах він викликає лише теоретичний інтерес.

Узагальнюючи наведені погляди, можна зробити висновок про те, що, визначаючи поняття "ринок праці", варто виходити з вимог комплексного, системного і діалектичного підходу із застосуванням методології соціально-економічного аналізу. Комплексний підхід до визначення цього поняття складається в сукупному урахуванні організаційно-економічних, соціально-психологічних, правових та інших аспектів за умов домінування соціально- економічних. Системний підхід відображає урахування взаємозв'язків між окремими аспектами, механізмами ринку праці та їх елементів і складається в розробці кінцевих цілей, визначенні шляхів їх досягнення. 3 погляду діалектичного методу, ринок праці варто розглядати як сукупність відносин між людьми з приводу відтворення робочої сили.

Аеякі протиріччя є актуальними при визначенні об'єкта ринку праці. Важливо з'ясувати, що є товаром на цьому ринку: робоча сила чи праця?

Робоча сила як сукупність фізичних та духовних здібностей людини є невід'ємною від робітника, їі не можна продати окремо, вона не може бути власністю покупця. Роботодавець може бути лише наймачем робочої сили на деякий час. Отже, робоча сила виступає товаром за умови, що людина є їі власником, вільно розпоряджається нею, а також відокремлена від засобів виробництва, не має засобів для існування і при цьому єдиним джерелом їх отримання є продаж товару "робоча сила". Через це продаж робочої сили не можна відкласти на деякий час, чекаючи більш сприятливого співвідношення попит-пропозиція.

Праця - це діяльність людини, сукупність цілеспрямованих дій, що потребують фізичної або розумової енергї̈, і має за мету створення матеріальних і духовних цінностей. Поняття "праця" в багатьох джерелах визначається як доцільна діяльність людини, в процесі якої за допомогою знарядь праці вона діє на природу та використовує їі з метою створення матеріальних та духовних благ, необхідних для задоволення своїх потреб і розвитку людства. Здатність до праці не тотожна самій праці та 11 результатам, однак в процесі споживання, використання робочої сили вони є невіддільними. На ринку праці працівник не може продати, а роботодавець купити працю, поскільки їі не існує, тому відбувається купівля-продаж лише здатності до праці, тобто робітник надає їі в "оренду" роботодавцю при умові оплати через певний час. Таким чином, у процесі купівлі-продажу між суб'єктами ринку праці, роботодавець купляє здатність до праці, тобто робочу силу, проте його більше цікавить результат (розмір та якість праці), за який і здійснюється кінцевий розрахунок (оплата). Аише тоді спожитий товар "робоча сила" $є$ суспільно корисним. Аля найманого працівника, крім рівня заробітної плати, важливими є ряд негрошових чинників: умови праці, режим роботи та відпочинку, можливості навчання, просування по службі, взаємовідносини 3 колегами та керів- 
Таблиця 1. Тлумачення поняття "ринок праці"

\begin{tabular}{|c|c|c|}
\hline Автор & Визначення & Джерело \\
\hline $\begin{array}{l}\text { Шилов В., } \\
\text { Тихонов А., } \\
\text { Талов А. }\end{array}$ & $\begin{array}{l}\text { Засіб організації трудової діяльності, умови якої визначаються } \\
\text { купівлею-продажем товару «робоча сила» за критерієм } \\
\text { найбільшої ефективності }\end{array}$ & {$[10]$} \\
\hline Краснов Ю.М. & $\begin{array}{l}\text { Економічна категорія, що відображає кількісну та якісну } \\
\text { характеристику трудового потенціалу }\end{array}$ & {$[8$, c. 63$]$} \\
\hline Горілий А.Г. & $\begin{array}{l}\text { Ринок, що забезпечує роботою працівників та координує } \\
\text { рішення у сфері зайнятості }\end{array}$ & {$[7$, c. 4$]$} \\
\hline Мімандусова Г.І. & $\begin{array}{l}\text { Виконує функцію механізму розподілу та перерозподілу } \\
\text { суспільної праці по галузях господарства, видах та формах } \\
\text { діяльності, за критерієм ефективності праці та виробництва у } \\
\text { відповідності із структурою суспільних потреб та форм } \\
\text { власності }\end{array}$ & {$[11$, c. 6$]$} \\
\hline Васильченко В.С. & $\begin{array}{l}\text { Вираз конкретних систем суспільної організації найманої праці } \\
\text { в умовах товарно-грошових відносин, який забезпечує } \\
\text { функціонування ринкової економіки на основі дії закону } \\
\text { попиту і пропозиції }\end{array}$ & {$[3$, c. 7$]$} \\
\hline $\begin{array}{l}\text { Головко М.Л., } \\
\text { Пастухов В.П. }\end{array}$ & $\begin{array}{l}\text { Економічна категорія, що є виразом певних суспільних } \\
\text { відносин між попитом та пропозицією робочої сили }\end{array}$ & {$[6$, c. 30$]$} \\
\hline Маршавін Ю.М. & $\begin{array}{l}\text { Сфера, в якій формуються і реалізуються товарно-грошові та } \\
\text { соціальні відношення з приводу купівлі-продажу робочої сили } \\
\end{array}$ & {$[10$, c. 11$]$} \\
\hline Петюх В.П. & $\begin{array}{l}\text { «...По-перше, як категорія, що характеризує систему соціально- } \\
\text { економічних відносин, що мають товарний характер, } \\
\text { пронизують фази відтворення індивідуальної робочої сили } \\
\text { (виробництво, розподіл, обмін, використання), всі ланки та } \\
\text { ступені суспільного виробництва, і регулюються ринковою } \\
\text { кон’юнктурою, системою соціального партнерства, } \\
\text { юридичними, правовими, морально-етичними нормами та } \\
\text { національними традиціями, а по-друге - система механізмів...» }\end{array}$ & {$[12$, c. 14$]$} \\
\hline Лібанова Е.М. & $\begin{array}{l}\text { Система суспільних відносин, соціальних - в тому числі, } \\
\text { юридичних (норм та інститутів), які забезпечують нормальне } \\
\text { відтворення та ефективне використання праці, кількість і якість } \\
\text { якої відповідним чином винагороджується }\end{array}$ & {$[9$, c. 12$]$} \\
\hline
\end{tabular}

Ажерело: складено авторами на основі літературних джерел.

ництвом тощо. Важливо відмітити, що в результаті купівлі-продажу товар "робоча сила" не відокремлюється від попереднього власника, тобто фактично об'єктом купівлі-продажу є право використовувати робочу силу (здатність до праці), враховуючи, що предметом торгу $\epsilon$ не лише певний вид здатностей виконувати деякі трудові функції, але й тривалість та умови виконання цих функцій.

Ми цілком поділяємо думку вчених-економістів, які вважають, що товар на ринку праці виступає у вигляді робочої сили, розглядаючи її як сукупність фізичних, духовних якостей, якими вона виробляє будь-які споживчі вартості [12]. Товару "робоча сила" на відміну від інших товарів характерне те, що здатність людини до праці визначається їі фізичним станом здоров'я (працездатність) та професійно-кваліфікаційним рівнем (дієздатність). Робоча сила - не лише особистісний фактор виробництва, але і єдиний товар, що здатний створювати додаткову вартість, доходи від якої покривають усі ці затрати. Крім того, даному ринку властива здатність до самовдосконалення, саморозвитку та примноження суспільного блага.

Нині серед науковців немає єдиної точки зору щодо визначення сутності ринку праці, по- скільки це поняття охоплює значну частину відносин у суспільстві (табл. 1). Аеякі автори при розкритті суті ринку праці роблять наголос на сфері обігу товару "робоча сила", ряд економістів вважають, що ринок праці є системою лише суспільних відносин у сфері праці. Широко трактує поняття "ринок праці" В. Петюх, враховуючи комплексний та системний підхід до його визначення і розглядаючи його як "сучасний регульований ринок праці" [12, с. 14]. Визначення білоруських науковців найбільш повно відповідає вимогам до ринку праці згідно з Концепцією Міжнародної організації праці (МОП) щодо забезпечення продуктивної зайнятості населення.

Під час визначення поняття "ринок праці" так багато уваги приділяється сфері обміну через те, саме в ній відбувається процес купівліпродажу товару. Однак невірно обмежувати ринок праці лише сферою обміну. Оскільки при цьому не беруться до уваги особисті інтереси, соціальні потреби працівників, які нині набувають все більшого значення. Крім того, ринок праці забезпечує процес відтворення робочої сили, що і визначає економічну суть ринкових процесів.

Вважаємо, що ринок праці - це складна, динамічна система суспільних, економічних, 
правових відносин щодо попиту та пропозиції робочої сили та форм і методів узгодження інтересів його ринкових суб'єктів.

Ознайомившись із поняттям "ринок праці", необхідно визначитись із його структурою або складом. Оскільки ринок праці є механізмом погодження інтересів роботодавців, які пред'являють попит на робочу силу, та її продавців найманих працівників, то основними його елементами є попит, пропозиція робочої сили, тї ціна та вартість.

Попит розглядається як загальна потреба економіки в робочій силі, тобто відображає обсяги та структуру потреб країни, галузі, регіону з боку всіх підприємств, фірм, установ, організацій тощо. Отже, попит формують роботодавці, що приймають рішення щодо найму робочої сили.

В. Васильченко розглядає попит на робочу силу в вузькому аспекті як індивідуальний та у широкому - як сукупний. Під індивідуальним розуміє платоспроможний попит на робочу силу певної якості конкретного підприємства, який можна арифметично зіставити з відповідною пропозицією. А сукупний попит визначає як загальну кількість робітників, службовців, спеціалістів, у яких є потреба на вільні робочі місця та вакансії у цьому місті, районі, області. В такому випадку просте арифметичне зіставлення попиту та пропозиції буде хибним, оскільки на деякі вакансії можуть бути зайві претенденти, а на інші їх може не вистачити [3]. Інші вважають, що попит на робочу силу визначається не лише кількістю, але й якістю вільних робочих місць, які існують в економіці, функціонують або потребують заповнення. Водночас кількість економічно доцільних робочих місць визначає ефективний попит, а сукупний попит включає також і зайняті працівниками, але неефективні робочі місця, що формують надлишок робочої сили тобто частину прихованого безробіття [9, с. 22].

На наш погляд, попит на цьому ринку визначається кількістю та якістю вільних робочих місць (вакансій), а також і зайнятих, aле таких, які з тих чи інших причин на конкретний момент потребують заміни працівників.

Слід зазначити, що попит на ринку праці має деякі особливості, які зумовлені тим, що специфічний товар "робоча сила", на відміну від звичайних товарів, купляється для виробництва продукції чи надання послуг, а не для задоволення потреб споживача. Хоча в якійсь мірі це можна заперечити, оскільки виробляючи продукцію, надаючи послуги, власник робочої сили в кінцевому результаті задовольняє потреби споживачів (у тому числі й свої), а роботодавець виступає між ними як посередник.

Пропозиція характеризує чисельність і структуру населення, що пропонує свою здатність до праці та отримує за це фонд життєвих благ. В основному вона залежить від суспільно-демографічної ситуації, системи оплати праці, кваліфікаційного складу, підготовки та перепідготовки кадрів та ін. Питання пропозиції праці вирішує сам робітник, зважаючи на $\dddot{1}$ привабливість та підприємство-роботодавця, свою стать, вік, освіту, професію, кваліфікацію, а також у залежності від наявних можливостей так чи інакше використовувати свій час.

Як уже зазначалось, на ринку праці робітник пропонує свою здатність до праці. Індивід на такому ринку пропонує три речі: час роботи, якість праці та інтенсивність. Час роботи визначається теорією корисності. Це означає, що індивід здійснює вибір між корисністю "час роботи", який приносить йому дохід, та корисністю "час відпочинку", що теж є не менш важливим і необхідним. Проте слід врахувати, що час обмежений (24 години на добу), тому індивіду необхідно розподілити його між роботою та відпочинком. Якість робочої сили включає всі особливості та здібності людини (освіту й кваліфікацію, фізіологічні, фізичні, професійні дані, мобільність і т. А.). Відповідно інтенсивність праці визначається у підвищенні їі продуктивності.

Під впливом економічних, соціальних, політичних, культурних та інших чинників формується співвідношення попиту та пропозиції або кон'юнктура ринку, що відображає його стан. Виходячи 3 цього відношення, визначаються розміри заробітної плати на конкретні види трудової діяльності, а також рівень зайнятості.

Можливі три кон'юнктури ринку праці [9]:

- трудодефіцитна - на ринку праці є дефіцит кадрів;

- трудонадлишкова - у зв'язку з надлишком пропозиції на ринку праці спостерігається безробіття;

- рівноважна - попит відповідає його пропозиції, в цьому випадку можна говорити про повну зайнятість.

Робоча сила як товар має ціну та вартість. У сучасному товарному виробництві, що базується на найманій робочій силі, заробітна плата це елемент ринку праці, що виступає як ціна, за якою найманий працівник продає свою робочу силу. Аля найманого працівника заробіт- 
на плата - це трудовий дохід, який він отримує в результаті здатності до праці та який має забезпечити об'єктивно необхідні умови відтворення робочої сили. Аля підприємства заробітна плата - це елемент витрат на виробництво, що включається до собівартості проАукції, робіт (послуг) і водночас головний чинник забезпечення матеріальної заінтересованості працівників у досягненні високих кінцевих результатів. Існують такі форми заробітної плати: погодинна, відрядна, контрактна. Погодинна ставка оплати праці розраховується діленням вартості робочої сили на кількість годин денної праці тобто передбачає нарахування оплати праці за відпрацьований час. Контрактна заробітна плата визначається умовами трудового договору (контракту). Відрядна ж використовується, коли за основу беруть кількість виконаної роботи або виробництво [7].

Вартість робочої сили визначається роботодавцем, який не лише виплачує заробітну плату, а й несе витрати на її утримання. Вона включає такі витрати: пряма оплата; оплата за невідпрацьований час; премії та нерегулярні виплати; заробітна плата в натуральній формі, пільги, послуги; допомога в натуральній та грошовій формі; оплата житла працівників; професійне навчання; утримання громадських служб; соціальне забезпечення працівників; витрати, не віднесені до інших груп. Встановлено, що реально на практиці вартість робочої сили на 30-60\% вища, ніж ï ціна [3, с. 47].

Сутність ринку праці простежується через виконувані їм у соціально-економічному житті функції. Функції ринку праці визначаються роллю виробництва в житті суспільства і роллю робочої сили в процесі виробництва, коли іiі використання виступає найважливішим джерелом доходу.

Соціальна функція ринку праці полягає в забезпеченні оптимального рівня доходів і добробуту людей, відтворення здібностей працівників. Ця функція набула особливого значення при усвідомленні пріоритетної ролі людського капіталу в соціально-економічному розвитку.

Економічна функція ринку праці зводиться до раціонального залучення, розподілу, регулювання і використання робочої сили. Цю функцію виконує особлива категорія робочої сили з наявністю підприємницьких здібностей, вмінь та навичок.

Інформативна функція реалізується за рахунок забезпечення економічною інформацією суб'єктів національної економіки. Господарюючі суб'єкти одержують інформацію про ціни на робочу силу. Реальна і потенційна робоча сила завдяки цій інформації має можливість прийняти рішення про свою перепідготовку, підвищення кваліфікації, одержання професійної освіти тощо. На основі цієї інформації, механізм саморегулювання ринку праці реалізує систему соціально-трудових відносин і сприяє дотриманню балансу інтересів між найманими працівниками, роботодавцями і державою.

Стимулююча функція ринку праці здійснюється на основі отриманої раніше інформації. Вона сприяє розгортанню конкуренції між його учасниками, підвищенню зацікавленості у високоефективній праці, поліпшенні кваліфікації і зміні професії. Конкуренція на ринку праці відбувається у декількох напрямах. Між собою конкурують носії робочої сили за більш вигідні умови $\dddot{1} і$ продажу, наймачі за більш вигідні умови покупки робочої сили, носії робочої сили за більш вигідні умови їі продажу і наймачі за більш вигідні умови їі покупки на ринку праці одночасно.

Регулююча функція стимулює здібності до саморегулювання ринку праці, який найчастіше має потребу в додатковому регулюванні ззовні. На ринку праці відбувається регулювання ціни, потоків робочої сили, рівня зайнятості й інших показників, тобто ринок праці регулює надлишок людських ресурсів, їх оптимальне розміщення й ефективне використання.

Однак виділяють також інші класифікації функцій, зокрема, такі, як посередницька (ринок праці встановлює зв'язок між роботодавцями і найманими працівниками, які виходять на ринок для задоволення взаємних інтересів і потреб щодо вигідних умов купівлі-продажу товару "робоча сила"); відтворювальна (ринок праці встановлює рівновагу між попитом та пропозицією робочої сили, при цьому тут діє закон вартості і відбувається загальне визнання витрат праці на відтворення товару "робоча сила" та його суспільної корисності); оздоровлююча (ринок праці дає можливість діставати перевагу в конкурентній боротьбі працівникам з вищими якісними показниками робочої сили) [12].

Всі функції знаходяться в тісному взаємозв'язку і взаємозалежності та включають всі аспекти функціонування ринку праці.

\section{ВИСнОВКИ}

Підсумовуючи вищевикладене, можна зазначити, що сучасний стан розвитку суспільства 
вимагає особливої уваги до формування та ефективного розвитку ринку праці. Це можна реалізувати в двох площинах: конкретно-економічній та теоретико-методологічній. У другому випадку в центрі уваги опиняється теорія ринку праці та їі складові, в якому чільне місце відводиться понятійному апарату. Сучасні економічні умови в Україні потребують нових підходів вирішення проблемних питань щодо співвідношення попиту та пропозиції на ринку праці, демографічної ситуації, посилення міграційних процесів, зниження рівня реальних доходів і добробуту населення.

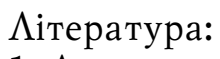

1. Ачкасов A.E. Стратегія регулювання зайнятості населення України. Житомир, 2002. 512 c.

2. Бондаревська К.В. Сучасні тенденції розвитку ринку праці в контексті соціальної безпеки держави. Проблеми економіки. 2019. № 3 (41). C. 255-262. URL: https://www.problecon.com/export_pdf/problems-of-economy2019-3_0-pages-255_262.pdf

3. Васильченко В.С., Василенко П.М. Ринок праці: теоретичні основи і державна практика: посібник для працівників державної служби зайнятості. Київ, 2000. 318 с.

4. Герасимчук B.I. Соціально-орієнтований ринок праці і проблеми його становлення. К.: Принт Експрес, 2000. 32 с.

5. Гнибіденко І.Ф., Колот А.М., Новікова О.Ф. Соціальна безпека: теорія та українська практика: монографія. Київ: КНЕУ, 2006. 292 с.

6. Головко М.А., Пастухов В.П. Зайнятість населення України: соціально-економічні, правові та історичні аспекти праці. К.: Наукова Аумка, 1998. 381с.

7. Горілий А.Г. Економіка ринків праці: навч. посібник. Тернопіль: Видавництво Карп'юка, 1999. 253 с.

8. Краснов Ю.М. Економічна стратегія активної політики ефективної зайнятості населення. К.: Знання України, 2001. 253 с.

9. Аібанова Е.М. Ринок праці: навч. посібник. К.: Центр Навчальної літератури, 2003. $224 \mathrm{c}$.

10. Маршавін Ю.М. Регулювання ринку праці України: теорія і практика системного підходу: монографія. К.: Альтерпрес, 2011. 396 с.

11. Мімандусова Г.І. Ринок праці в Україні: тенденції та перспективи (соціально-економічний аналіз): монографія. К.: Інститут соціології НАНУ, 1999. 96 с.

12. Петюх В.М. Ринок праці: навч. посібник. K.: KHEУ, 1999. 288 c.
References:

1. Achkasov, A.Ye. (2002), Stratehiia rehuliuvannia zajniatosti naselennia Ukrainy [Strategy of employment regulation of the population of Ukraine], Zhytomyr, Ukraine.

2. Bondarevs'ka, K.V. (2019), "Current Trends in the Development of the Labor Market in the Context of Social Security of the State", Problemy ekonomiky, [Online], vol. 3 (41), available at: https://www.problecon.com/export_pdf/problems-of-economy-2019-3_0-pages-255_262.pdf (Accessed 4 Apr 2021).

3. Vasyl'chenko, V.S. and Vasylenko, P.M. (2000), Rynok pratsi: teoretychni osnovy i derzhavna praktyka [Labor market: theoretical foundations and public practice], Kyiv, Ukraine.

4. Herasymchuk, V.I. (2000), Sotsial'nooriientovanyj rynok pratsi i problemy joho stanovlennia [Socially-oriented labor market and problems of its formation], Prynt Ekspres, Kyiv, Ukraine.

5. Hnybidenko, I.F. Kolot, A.M. and Novikova, O.F. (2006), Sotsialna bezpeka: teoriia ta ukrainska praktyka [Social Security: Theory and Ukrainian Practice], KNEU, Kyiv, Ukraine.

6. Holovko, M.L. and Pastukhov, V. P. (1998), Zajniatist' naselennia Ukrainy: sotsial'no-ekonomichni, pravovi ta istorychni aspekty pratsi [Employment of the population of Ukraine: socioeconomic, legal and historical aspects of labor], Naukova dumka, Kyiv, Ukraine.

7. Horilyj, A.H. (1999), Ekonomika rynkiv pratsi [Labor market economics], Vydavnytstvo Karp'iuka, Ternopil', Ukraine.

8. Krasnov, Yu.M. (2001), Ekonomichna stratehiia aktyvnoi polityky efektyvnoi zajniatosti naselennia [Economic strategy of active policy of effective employment], Znannia Ukrainy, Kyiv, Ukraine.

9. Libanova, E.M. (2003), Rynok pratsi [Labor market], Tsentr Navchal'noi literatury, Kyiv, Ukraine.

10. Marshavin, Yu.M. (2011), Rehuliuvannia rynku pratsi Ukrainy: teoriia i praktyka systemnoho pidkhodu [Regulation of the labor market of Ukraine: theory and practice of a systems approach], Al'terpres, Kyiv, Ukraine.

11. Mimandusova, H.I. (1999), Rynok pratsi v Ukraini: tendentsii ta perspektyvy (sotsial'noekonomichnyj analiz) [Labor market in Ukraine: trends and prospects (socio-economic analysis) ], Instytut sotsiolohii NANU, Kyiv, Ukraine.

12. Petiukh, V.M. (1999), Rynok pratsi [Labor market], KNEU, Kyiv, Ukraine.

Стаття надійшла до редакчї 12.04.2021 p. 
УAK 661.65
М. М. Курбацька,
к. е. н., Аоцент, Аоцент кафедри маркетингу,
Аніпровський Аержавний аграрно-економічний університет, м. Аніпро
ORCID ID: 0000-0003-2567-3060
I. Г. Кадирус,
к. е. н., Аоцент, доцент кафедри маркетингу,
Аніпровський Аержавний аграрно-економічний університет, м. Аніпро
ORCID ID: 0000-0002-5024-6549
О. А. Савенко,
к. е. н., Аоцент, доцент кафеАри менеджменту і права,
Аніпровський Аержавний аграрно-економічний університет, м. Аніпро
ORCID ID: 0000-0002-2362-6263
К. В. Нечипоренко,
старший викладач кафеАри менеджменту і права,
Аніпровський державний аграрно-економічний університет, м. Аніпро
ORCID ID: 0000-0002-2421-6530

DOI: $10.32702 / 2306-6792.2021 .7-8.60$

\title{
УАОСКОНАЛЕННЯ АОГІСТИЧНИХ СИСТЕМ АЛЯ ЗАБЕЗПЕЧЕННЯ ПРИНЦИПІВ СТІЙКОГО РОЗВИТКУ ПІАПРИЕМСТВА
}

\author{
L. Kurbatska, \\ $\mathrm{PhD}$ in Economics, Associate Professor, Associate Professor of the Department \\ of Marketing, Dnipro State Agrarian and Economic University, Dnipro \\ I. Kadyrus, \\ $\mathrm{PhD}$ in Economics, Associate Professor, Associate Professor of the Department \\ of Marketing, Dnipro State Agrarian and Economic University, Dnipro \\ O. Savenko, \\ $\mathrm{PhD}$ in Economics, Associate Professor, Associate Professor of the Department \\ of Management and Law, Dnipro State Agrarian and Economic University, \\ K. Nechyporenko, \\ Senior Lecturer of the Department of Management and Law, Dnipro State Agrarian and Economic Universit
}

\section{IMPROVEMENT OF LOGISTICS SYSTEMS TO ENSURE THE PRINCIPLES OF SUSTAINABLE ENTERPRISE DEVELOPMENT}

Визначено, що реалізація стратегічних цілей підприємства стає можливою при створенні таких логістичних систем, які були б спрямовані на досягнення високого рівня обслуговування споживачів, дозводили б оптимізувати його матеріальні, інформаційні, фінансові потоки і тим самим значно скоротити витрати підприємства. Це дозволить розробити сучасні технології логістичного менеАжменту і забезпечити підвищення економічної ефективності господарювання підприємства.

Встановлено, що в процесі стратегічного управління стійким розвитком підприємства доцільно орієнтуватися на базові та доповнюючі принципи. Аля побудови більш ефективної логістичної системи виробничого підприємства необхідно обгрунтувати та підготувати проект, який повинен складатися з декілька послідовних етапів.

Визначено, що основними напрямами удосконалення догістичної системи підприємств будуть виступати принципи системного підходу, що розкриваються в інтеграції та чіткій взаємодії всіх елементів догістичної системи. Синтез логістичної системи із використанням системного підходу повинен бути представлений у вигляді етапів, виконання яких дозволить провести цей процес послідовно і своєчасно скоректувати цілі, заАачі та моделі прийняття управлінських рішень на кожному етапі синтезу. 
Аля забезпечення принципів стійкого розвитку, запропоновано використовувати напрями удосконахення логістичних систем підприємства, які вкдючають такі складові: економічну (напрям розвитку: комерційно-стійкий, фінансово-стійкий, організаційно-стійкий, виробничо-технічно-стійкий та інноваційно-стійкий); соціальну (напрям розвитку: каАрово-стійкий та доходно-стійкий) та екологічну (напрям розвитку: ресурсно-стійкий та навколишньостійкий).

Аоведено, що забезпечення сталого розвитку підприємства, стабільності результатів його діяльності, досягнення цілей, що відповідають інтересам керівництва і суспільства загалом, неможливе без розробки і впровадження комплексу стратегічних заходів, реалізація яких обумовлюється рівнем логістичної інфраструктури і призводить до необхідності розгляду проблем ефективного управління підприємством.

It is determined that the realization of strategic goals of the enterprise becomes possible when creating such logistics systems that would be aimed at achieving a high level of customer service, would optimize its material, information, financial flows and thus significantly reduce costs. This will allow to develop modern technologies of logistics management and to increase the economic efficiency of the enterprise.

It is established that in the process of strategic management of sustainable development of the enterprise it is expedient to be guided by basic and complementary principles. To build a more efficient logistics system of a manufacturing enterprise, it is necessary to substantiate and prepare a project, which should consist of several successive stages.

It is determined that the main directions of improving the logistics system of enterprises will be the principles of a systematic approach, revealed in the integration and clear interaction of all elements of the logistics system. The synthesis of the logistics system using a systems approach should be presented in the form of stages, the implementation of which will allow this process to consistently and timely adjust the goals, objectives and models of management decisions at each stage of the synthesis.

To ensure the principles of sustainable development, it is proposed to use areas of improvement of logistics systems of the enterprise, which include the following components: economic (direction of development: commercially sustainable, financially sustainable, organizational-sustainable, production-sustainable and innovation-sustainable) social (development direction): personnel-sustainable and income-sustainable) and environmental (direction of development: resource-sustainable and environmentally sustainable).

It is proved that ensuring sustainable development of the enterprise, stability of its results, achieving goals that meet the interests of management and society as a whole is impossible without the development and implementation of a set of strategic measures, the implementation of which is determined by the level of logistics infrastructure and leads to effective management.

Ключові слова: логістична діяльність, логістика, логістичні послуги, логістична система, niдnрuємство.

Key words: logistic activity, logistics, logistics services, logistics system, enterprise.

\section{ПОСТАНОВКА ПРОБЛЕМИ}

Стрімкий розвиток інформаційно-комунікаційних технологій, зростання конкуренції на вітчизняному ринку і підвищення вимог споживачів на сьогодні є головними передумовами перегляду маркетингової політики підприємства щодо формування більш ефективної системи забезпечення його конкурентоспроможності, більш повного задоволення потреб споживачів. Одним із ключових інструментів виступає логістика та створення логістичних систем. Адже, для підвищення конкурентоспроможності суб'єктів господарювання є потреба у забезпеченні високого рівня розвитку логістичної системи і якості послуг, що надаються підприємством, та відповідних результатів їі функціонування.

Проблема підвищення якості логістичних послуг є все більш актуальною по мірі розвитку сфери виробництва, зростання транспортної складової, міграції населення, необхідності подолання територіальної роз'єднаності.

\section{АНАЛІЗ ОСТАННІХ ДОСЛІДЖЕНЬ І ПУБЛІКАЦІЙ}

Теоретичні та практичні аспекти щодо оцінки ефективності логістики на підприємстві досліджували такі вітчизняні та зарубіжні вчені: А. Бауерсокс, А. Клосс, А.М. Гаджинський, Б.А. Анікін, Е. Ворнер, Р. Ербе, А. Кісінг, А.Н. Родніков [9]. Прикладним проблемам логістики присвячено праці О.П. Величка, М.П. Бутка, В.Ю. Божанової [2], В.А. Аиканя, Є.В. Крикавського, I.I. Вініченка [16], О.М. Сумця [11], А.Г. Кальченко [4], В.В. Кривещенко та ін.

Концептуальний зміст механізму організаційно-економічного забезпечення логістичної системи і поетапного виконання рекомендацій по її формуванню розглядається багатьма вченими.

На думку Кальченко А.Г., логістична система - це "Організаційно-господарський механізм управління матеріальними та інформаційними потоками, який дає змогу досягти 
ефекту завдяки чіткій злагодженості у діях спеціалістів різноманітних служб, що беруть участь в управлінні матеріальним потоком" [4].

Тоді як Сумець О.М. вважає, що логістична система $€$ "адаптованою (самоналагоджуваною та самоорганізованою) системою 3 оберненим зв'язком, що виконує логістичні функції та логістичні операції і складається, зазвичай, із декількох систем та має розвинуті зв'язки із зовнішнім середовищем" [11].

Родніков А.Н. описує логістичну систему як "адаптивну систему із зворотними зв'язками, яка виконує ті чи інші логістичні функції (операції), складається із підсистем і має розвинуті внутрішньосистемні зв'язки та зв'язки із зовнішнім середовищем" [9].

Вивчення наукових праць, які присвячені сучасним тенденціям формуванню та розвитку логістичних систем підприємства свідчить про те, що більшість авторів звертають увагу на те, що система $є$ комплексною сукупністю більш простих підсистем, які мають загальну мету, що спрямована на забезпечення ефективного логістичного процесу на підприємстві. Тобто, частина науковців вважає що логістична діяльність здійснюється через виконання логістичних функцій, які є сукупністю логістичних процесів та логістичних операцій. Водночас проведений аналіз опублікованих праць свідчить про необхідність поглиблення наукових досліАжень, спрямованих розробку моделі підвищення ефективності логістичної системи підприємства.

\section{МЕТА ДОСЛІДЖЕННЯ}

Метою дослідження $є$ розробка практичних рекомендацій щодо удосконалення логістичних систем для забезпечення принципів стійкого розвитку підприємства.

\section{ВИКЛАД ОСНОВНОГО МАТЕРІАЛУ ДОСЛІДЖЕННЯ}

Використання логістичного підходу під час вирішення завдань щодо підвищення ефективності функціонування підприємства набуває нині все більшої актуальності. Підприємства, які досягли стратегічних переваг, завдяки компетентності в логістиці, визначають характер конкуренції в тих галузях, де вони функціонують. Останніми роками широкого розповсюдження набуло створення відділів логістики на

Рис. 1. Сукупність цілей сучасної логістики

\section{ЦІЛІ СУЧАСНОЇ ЛОГІСТИКИ}

Формування
оптимальних розмірів партій поставок та переробки
Якісне виконання всіх замовлень у встановлені строки
Узгодження політики розподілу з політикою виробництва продукиіi

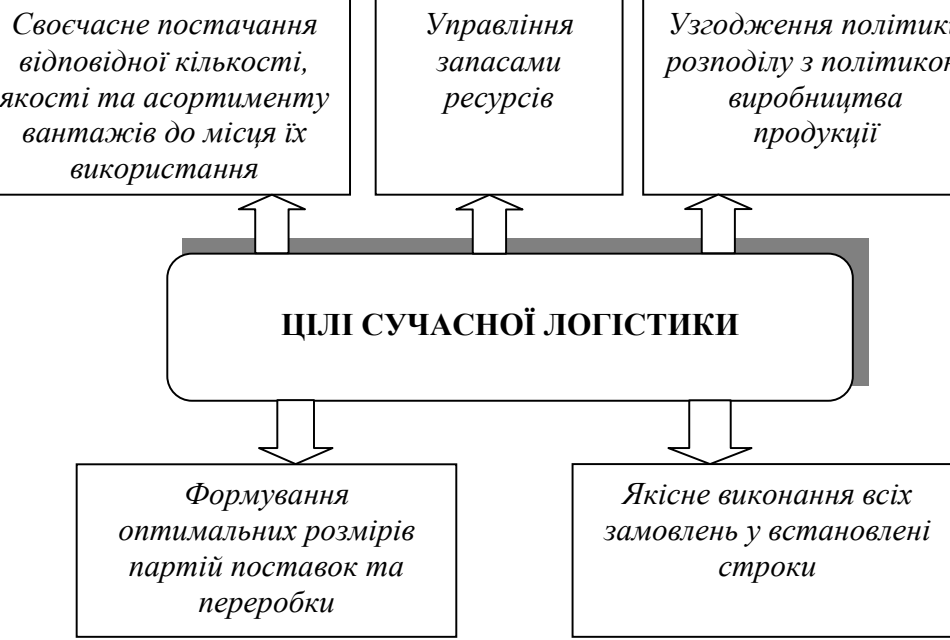

вітчизняних підприємствах різних форм власності.

Криворучко О. М. під логістикою розуміє "управління логістичними бізнес-процесами 3 метою задоволення вимог ринку з мінімальними операційними та капітальними витратами" [1].

Һогістика включає принципи та методи, за допомогою яких можна планувати, контролювати й керувати операціями, що виникають у процесі транспортування товарів до споживачів. Ао цілей логістики можна віднести (рис. 1).

3 метою забезпечення виробничими підприємствами безперервного виробництва, постачання високоякісних та безпечних товарів, виникає необхідність у використанні переваг маркетингу, логістики та формуванні логістичних систем. Реалізація стратегічних цілей підприємства стає можливою при створенні таких логістичних систем, які були б спрямовані на досягнення високого рівня обслуговування споживачів, дозволили б оптимізувати його матеріальні, інформаційні, фінансові потоки і тим самим значно скоротити витрати підприємства. Це дозволяє виробити сучасні технології логістичного менеджменту і забезпечити підвищення економічної ефективності господарювання підприємства.

Ефективна логістична система виробничого підприємства забезпечує досягнення мети та завдань різного рівня складності при дотриманні багатоваріантного характеру визначення цілей та прийняття управлінських рішень під впливом внутрішніх та зовнішніх факторів. Aле необхідно орієнтуватися на кращі результати, 


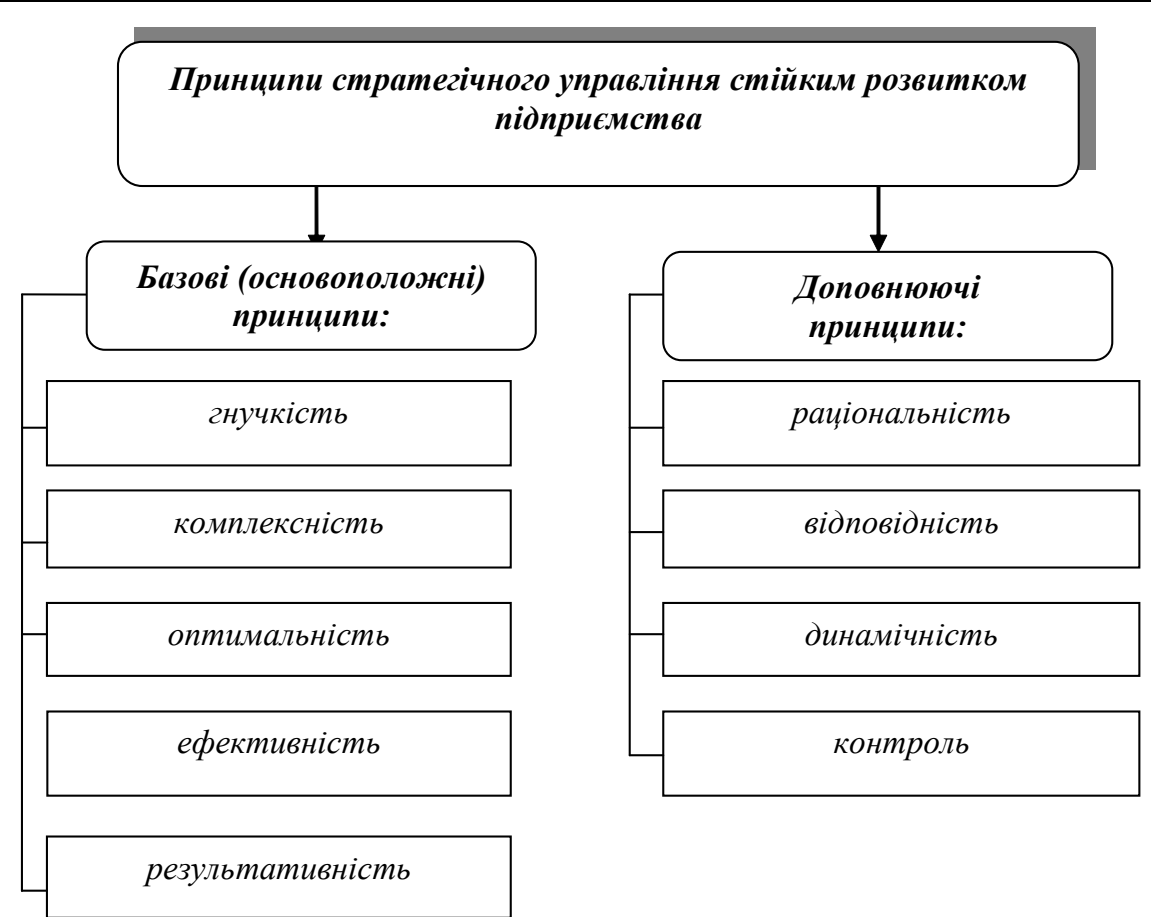

Рис. 2. Принципи стратегічного управління, що забезпечують стійкий розвиток підприємства

Ажерело: узагальнено авторами [2; 4].

бо ринкові відносини постійно формують нові вимоги до економічного зростання та стійкого розвитку підприємств. У процесі стратегічного управління стійким розвитком підприємства доцільно орієнтуватися на базові (основоположні) принципи та доповнюючі принципи (рис. 2).

1. Ао базових (основоположних) принципів відносяться:

- гнучкість як здатність системи передбачати, протистояти та пристосовуватись до мінливого середовища, здатність коригувати управлінські рішення, спрямовані на подальший розвиток підприємства за зміни умов його функціонування;

- комплексність передбачає об'єднання всіх управлінських рішень в єдину систему, що дозволяє забезпечити їх взаємодію в процесі впливу та реалізацію цих рішень, а також визначити переваги в управлінні господарською діяльністю підприємств;

- оптимальність - сприяє забезпеченню оптимального вибору між послідовністю виконання завдань у розрізі кожного елементу системи управління загалом та, зокрема, всередині кожного окремого елемента;

- ефективність передбачає, що стратегічне управління розвитком підприємства відбувається $з$ використанням системного підходу до управління, яке націлене на скорочення витрат ресурсів, організацію процесів та видів діяльності, а також підвищення доходів за джерелами їх надходження від кожного керованого елемента системи;

- результативність - полягає в отриманні у процесі оцінювання бажаних кінцевих результатів при управлінні керованими елементами системи стратегічного управління, а також при управлінні підсистемами виробництва й реалізації продукції, фінансового стану й ресурсного потенціалу підприємства.

2. Аоповнюючі принципи:

- раціональність - розкривається через гармонійну узгодженість в управлінні з усіма елементами системи, досягнення ефективності розвитку підприємства, аргументованість управлінських рішень щодо завдань управління елементами системи;

- відповідність - передбачає визначення економічної ситуації в країні, галузі, безпосередньо на підприємстві; врахування світових тенденцій на ринках товарів та послуг, оцінювання конкурентних позицій серед вітчизняних та іноземних товаровиробників;

- динамічність - полягає в систематичному оцінюванні величини впливу зовнішніх та внутрішніх чинників на діяльність підприємства;

- контроль - система дій по забезпеченню постійного нагляду за процесом впровадження в дію управлінських рішень на всіх рівнях управління, при одночасному врахуванні адап- 
тації до змін мікро- та макросередовища підприємства [2].

Аля побудови більш ефективної логістичної системи виробничого підприємства необхідно обгрунтувати та підготувати проект. 3 цією метою доцільно дотримуватись таких послідовних етапів:

1) передпроектна підготовка (аналітичний етап) передбачає формування інформаційної бази для проектування;

2) проектна діяльність передбачає безпосередню розробку проекту на основі зібраних та проаналізованих даних, спрямованого на досягнення кінцевої мети;

3) реалізація проекту розробка рекомендацій щодо впровадження і реалізації механізму з проектування логістичних систем.

Також слід зазначити, що на кожному етапі будуть свої цілі та завдання підприємства в залежності від виду його діяльності та спеціалізації.

Проектування та планування логістичної системи необхідно починати 3 ретельного дослідження по-

\begin{tabular}{|c|c|}
\hline НАПРЯМ РОЗВИТКУ & ХАРАКТЕРИСТИКА НАПРЯМУ РОЗВИТКУ \\
\hline 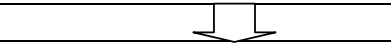 & $\gamma_{1}$ \\
\hline \multicolumn{2}{|c|}{ Економічна складова } \\
\hline Комерційно-стійкий & $\begin{array}{l}\text { Нарощування клієнтської бази для забезпечення } \\
\text { безперебійного виробництва та ефективного збуту } \\
\text { продукції }\end{array}$ \\
\hline Фінансово-стійкий & $\begin{array}{l}\text { Забезпечення постійного отримання бажаного } \\
\text { прибутку, що дозволить покращити фінансове } \\
\text { становище підприємства, утримувати його } \\
\text { конкурентні позиції на ринку та збільшити обсяги } \\
\text { виробництва }\end{array}$ \\
\hline Організаційно-стійкий & $\begin{array}{l}\text { Забезпеченість підприємства } \\
\text { висококваліфікованими кадрами є важливим } \\
\text { стратегічним напрямком його розвитку та засобом } \\
\text { досягнення стійких конкурентних переваг в умовах } \\
\text { конкуренції }\end{array}$ \\
\hline Виробничо-технічно-стійкий & $\begin{array}{l}\text { Підтримання матеріально-технічної бази } \\
\text { підприємства в належному стані для } \\
\text { безперебійного виробництва, запобігання простоям } \\
\text { та технічним ризикам }\end{array}$ \\
\hline Інноваційно-стійкий & $\begin{array}{l}\text { Застосування в процесі управління підприємством } \\
\text { інноваційних інструментів, зокрема логістичних }\end{array}$ \\
\hline \multicolumn{2}{|l|}{ 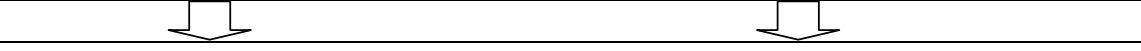 } \\
\hline \multicolumn{2}{|c|}{ Соціальна складова } \\
\hline Кадрово-стійкий & $\begin{array}{l}\text { Постійна фінансова та соціальна підтримка } \\
\text { персоналу підприємства, запровадження системи } \\
\text { мотивації та стимулювання праці, підвищення } \\
\text { рівня кваліфікації персоналу }\end{array}$ \\
\hline Доходно-стійкий & $\begin{array}{l}\text { Забезпечення зростання заробітної плати персоналу } \\
\text { підприємства, їх кар'єрне зростання }\end{array}$ \\
\hline \multicolumn{2}{|l|}{25} \\
\hline \multicolumn{2}{|c|}{ Екологічна складова } \\
\hline Ресурсно-стійкий & $\begin{array}{l}\text { Застосування енерго- і ресурсозберігаючих } \\
\text { технологій та заходів щодо регулювання } \\
\text { виробничої діяльності підприємства }\end{array}$ \\
\hline Навколишньо-стійкий & $\begin{array}{l}\text { Забезпечення зменшення негативного впливу на } \\
\text { навколишнє середовище, екологізація виробництва }\end{array}$ \\
\hline
\end{tabular}

\section{Рис. 3. Заходи удосконалення логістичних систем підприємства} для забезпечення принципів стійкого розвитку

Ажерело: узагальнено авторами [3].

точної ситуації, аналіз якої полягає в оцінці впливу факторів зовнішнього середовища, вивченні наявної логістичної системи, а також виявленні змін, які необхідно здійснити. Аослідження проводиться шляхом ситуаційного аналізу, за допомогою якого визначається внутрішній порядок логістичної системи, оцінюється ринкове та конкурентне середовище підприємства. Водночас аналізується як весь логістичний процес підприємства, так і окремо взята логістична функція.

У залежності від необхідної глибини аналізу, формується і зміст дослідження. Одним із показників реальної ефективності обраної логістичної системи може бути їі стійкість, тобто дотримання прийнятих стандартів обслуговування [3]. Зокрема, це може бути параметр порогового рівня сервісу, забезпечений логістичною системою з мінімальними загальними витратами, який задає основу для оцінювання сервісних можливостей логістичної системи. Базові можливості системи можна змінити декількома способами: шляхом зміни кількості складів, що використовує система; зміною часу одного чи декількох функціональних циклів для підвищення швидкості або стабільності операцій; зміною політики формування запасів [4].

Механізм управління логістичною системою підприємства $є$ сукупністью наукових методів та засобів, які впливають на логістичні процеси (що відбуваються в логістичній системі підприємства), регулюють, аналізують та вдосконалюють їх, здійснюють моніторинг, прогнозування, планування та корегування руху логістичних потоків [4].

Механізм управління догістичною системою суб'єкта господарювання повинен вико- 
нувати такі функції: прийняття управлінських рішень на основі інформації, яка стосується реального стану логістичної системи підприємства; регулювання логістичних потоків; здійснення контролю щодо виконання логістичних операцій та функціонування логістичної системи; планування логістично системи підприємства та оптимізація бізнеспроцесів у ній; раціоналізація транспортної системи; організація складського господарства [5].

Головною метою логістичної системи підприємства є забезпечення наявності необхідних товарів у потрібній кількості й асортименті, встановленої якості, в необхіАному місці й у визначений час, у максимально можливому ступені підготовлених до виробничого процесу або особистого споживання при заданому рівні логістичних витрат [7].

Основними напрямами удосконалення логістичної системи підприємств будуть виступати принципи системного підходу, що розкриваються, передусім, в інтеграції та чіткій взаємодії всіх елементів логістичної системи. Синтез логістичної системи із використанням системного підходу повинен бути представлений у вигляді етапів, виконання яких дозволить провести цю процедуру послідовно і своєчасно скоректувати цілі, задачі та моделі прийняття управлінських рішень на кожному етапі синтезу.

Ряд науковців вважає, що забезпечення розробки та функціонування логістичної системи підприємства відбувається 3 урахуванням матеріальних, фінансових та організаційних факторів (рис. 3).

Аля забезпечення принципів стійкого розвитку, пропонуємо використовувати напрями удосконалення логістичних систем підприємства, які включають такі складові: економічну (напрям розвитку: комерційно-стійкий, фінансово-стійкий, організаційно-стійкий, виробничо-технічно-стійкий та інноваційно-стійкий); соціальну (напрям розвитку: кадрово-стійкий та доходно-стійкий); екологічну (напрям розвитку: ресурсно-стійкий та навколишньостійкий).

Отже, забезпечення сталого розвитку підприємства, стабільності результатів його діяльності, досягнення цілей, що відповідають інтересам власників і суспільства в цілому, неможливе без розробки і впровадження комплексу стратегічних заходів, реалізація яких обумовлюється рівнем логістичної інфраструктури і призводить до необхідності розгляду проблем ефективного управління підприємством.

\section{ВИСНОВКИ:}

1. Встановлено, що для реалізації стратегічних цілей підприємства необхідно створити такі логістичні системи, які були б спрямовані на досягнення високого рівня обслуговування споживачів, а також дозволили б оптимізувати матеріальні, інформаційні, фінансові потоки підприємства і тим самим значно скоротили витрати. Це дозволяє виробити сучасні технології логістичного менеджменту і забезпечити підвищення економічної ефективності діяльності підприємства.

2. 3'ясовано, що визначальними сторонами поліпшення логістичної системи підприємств мають виступати положення системного підходу, що виражаються, насамперед, в інтеграції та певній взаємодії всіх складових логістичної системи.

\section{\ітература:}

1. Криворучко О.М. Сучасне розуміння поняття "якість логістичної діяльності" / О.М. Криворучко, А.Г. Овчаренко // Економіка транспортного комплексу. - 2018. - Вип. 31. - C. $150-163$.

2. Божанова В.Ю. Могістична діяльність підприємства: інновації та інтернет-маркетинг: навч. посібник / В.Ю. Божанова, Т.В. Котуранова, Ю.С. Булєєв, О.В. Цабій. - Аніпро: АВНЗ ПААБА, 2017. - 280 c.

3. Трифонова О.В. Формування оптимальних логістичних систем у процесі стратегічного управління стійким розвитком підприємства / О.В. Трифонова, О.Ю. Кравець // Економічний простір. - 2019. - № 142. - С. 217-226. [Електронний ресурс]. - Режим доступу: http:/ /srd.pgasa.dp.ua:8080/bitstream/123456789/ 2586/1/Tryfonova.pdf

4. Кальченко А.Г. Могістика: підручник / А.Г. Кальченко. - К.: КНЕУ, 2004. - 284 с.

5. Елетенко O.В. Механізм управління логістичною системою підприємства / O.В. Елетенко // Вісник Національного університету "Аьвівська політехніка". Проблеми економіки та управління. - 2008. - № 628. - С. 494-498.

6. Марковский В.А. Использование методики САР анализа для оценки әффективности логистической/ В.А. Марковский // Современные исследования социальных проблем. 2016. - № 2. - C. 4-11.

7. Очеретенко С.В. Використання знижок в логістичних системах підприємствах / С.В. Оче- 
ретенко, В.Ю. Кудріна // Системи управління, навігації та зв'язку. - 2019. - Вип. 3. - С. 72-75.

8. Репіч Т.А. Шляхи зниження логістичних витрат / Т.А. Репіч, Т.В. Новак // Молодий вчений. - 2018. - № 11 (2). - С. 185-189.

9. Родников А.Н. Аогистика: Терминологический словарь / Родников А.Н. - М.: Экономика, $1995 .-252$ с.

10. Соколовський С.А. Вдосконалення логістичної системи підприємства: моделювання сценаріїв та оцінка ефективності / С.А. Соколовський, М.О. Науменко // Фінансово-кредитна діяльність: проблеми теорії та практики. - 2018. - Вип. 2. - С. 236-245.

11. Сумець О.М. Рекомендації щодо запровадження синтетичного обліку логістичних витрат на підприємстві. Иогистика: проблеми и решения. Харків. - 2011. - № 4 (35). C. $42-47$.

12. Уткіна Ю.М. Стратегічне планування логістичної діяльності підприємства / Ю.М. Уткіна, Ю. Беседіна // Вісник економіки транспорту і промисловості. - 2017. Вип. 59. - С. 186-194.

13. Федотова I.В. Формування багаторівневої моделі логістичної системи / І.В. Федотова // Економіка транспортного комплексу. 2019. - Вип. 33. - С. 5-31.

14. Шкробот М.В. Удосконалення системи управління логістичними процесами підприємства/ М.В. Шкробот, А.А. Моргонюк // Молодий вчений. - 2018. - № 4 (2). - С. 849-854.

15. Шишкін В.О. Перспективи використання логістичної стратегії як умова забезпечення конкурентоспроможності підприємства [Електронний ресурс]/ В.О. Шишкін, Я.Ю. Бахметова // Modern economics. - 2019. - № 14. - C. 296-300. - Режим доступу: http:// nbuv.gov.ua/UJRN/modecon_2019_14_48

16. Вініченко I.I. Економічна стійкість підприємства та її складові / I.I. Вініченко, C.I. Крючок // Агросвіт. - 2016. - № 24. C. $15-20$.

\section{References:}

1. Kryvoruchko, O.M. and Ovcharenko, A.H. (2018), "Modern understanding of the concept of "quality of logistics", Ekonomika transportnoho kompleksu, vol. 31, pp. 150-163.

2. Bozhanova, V. Yu. Koturanova, T.V. Bulieiev, Yu.S. and Tsabij, O.V. (2017), Lohistychna diial'nist' pidpryiemstva: innovatsii ta internetmarketynh [Logistic activity of the enterprise: innovation and Internet marketing], Prydniprovs'ka derzhavna akademiia budivnytstva ta arkhitektury, Dnipro, Ukraine.
3. Tryfonova, O.V. and Kravets' O.Yu. (2019), "Formation of optimal logistics systems in the process of strategic management of sustainable development of the enterprise", Ekonomichnyj prostir, [Online], vol. 142, available at: https:// http://srd.pgasa.dp.ua:8080/bitstream/123456789/ 2586/1/Tryfonova.pdf (Accessed 30 March 2021).

4. Kal'chenko, A. H. (2004), Lohistyka [Logistics], KNEU, Kyiv, Ukraine.

5. Yeletenko, O. V. (2008), "The mechanism of management of the logistics system of the enterprise", Visnyk Natsional'noho universytetu "L'vivs'ka politekhnika", vol. 628, pp. 494-498.

6. Markovskyj, V. A. (2016), "Using the CAP analysis technique to assess the effectiveness of logistics", Sovremennye yssledovanyia sotsyal'nykh problem, vol. 2, pp. 4-11.

7. Ocheretenko, S. V. and Kudrina, V. Yu. (2019), "Use of discounts in logistics systems of enterprises", Systemy upravlinnia, navihatsii ta zv'iazku, vol. 3, pp. 72-75.

8. Repich, T. A. and Novak, T. V. (2018), "Ways to reduce logistics costs", Molodyj vchenyj, vol. 11, pp. 185-189.

9. Rodnikov, A.N. (1995), Logistika: Terminologicheskij slovar [Logistics: Glossary], Jekonomika, Moskva, Russia.

10. Sokolovs'kyj, S. A. and Naumenko, M. O. (2018), "Improving the logistics system of the enterprise: modeling scenarios and evaluating efficiency", Finansovo-kredytna diial'nist': problemy teorii ta praktyky, vol. 2, pp. 236-245.

11. Sumets, O.M. (2011), "Recommendations on implementation of synthetic accounting of logistic expenditures at the enterprise", Lohystyka: problemy y reshenyia, vol. 4 (35), pp. 42-47.

12. Utkina, Yu. M. and Besedina, Yu. (2017), "Strategic planning of logistics activities of the enterprise", Visnyk ekonomiky transportu i promyslovosti, vol. 59, pp. 186-194.

13. Fedotova, I. V. (2019), "Formation of a multilevel model of the logistics system", Ekonomika transportnoho kompleksu, vol. 33, pp. 5-31.

14. Shkrobot, M. V. and Morhoniuk, A. A. (2018), "Improving the management system of logistics processes of the enterprise", Molodyj vchenyj, vol. 4, pp. 849-854.

15. Shyshkin, V. O. and Bakhmetova, Ya. Yu. (2019), "The Perspectives of the Logistics Strategy Use as the Condition of Enterprise's Competitive Ability Providing", Modern economics, [Online], vol. 14, available at: https:// nbuv.gov.ua/UJRN/ modecon 20191448 (Accessed 20 March 2020).

16. Vinichenko, I. and Kriuchok, S. (2016), "The economic stability of the enterprise and its components", Agrosvit, vol. 24, pp. 15-20. Стаття надійшла до редакиії 06.04.2021 p. 
Ю. В. Масюк,

к. е. н., доцент, професор кафедри фінансів, банківської справи та страхування, Аніпровський Аержавний аграрно-економічний університет

ORCID ID: 0000-0001-6445-806X

DOI: $10.32702 / 2306-6792.2021 .7-8.67$

\title{
КАЮЧОВІ АСПЕКТИ ІНВЕСТИЦІЙНОГО ЗАБЕЗПЕЧЕННЯ АГРАРНИХ ПІАПРИЕМСТВ
}

\author{
Yu. Masyuk, \\ $\mathrm{PhD}$ in Economics, Associate Professor, Professor of the Department of Finance, \\ Banking and Insurance, Dnipro State Agrarian and Economic University
}

\section{KEY ASPECTS OF INVESTMENT SUPPORT OF AGRICULTURAL ENTERPRISES}

\begin{abstract}
У статті розглянуто сутність інвестицій та ключові аспекти інвестиційного забезпечення аграрних підприємств. Встановлено, що підприємство може досягати поставлені переА собою цілі лише тоді, коли його трансформація відповідає вимогам та змінам існуючого економічного середовища, що залежить від ії інвестиційної діяльності. Визначено, що аграрне виробництво сьогодні функціонує у надзвичайно складних умовах. Аоведено, що у 2020 році обсяги капітальних інвестицій в агропромислові сектори економіки України склали 36 млрА грн, капіталовкладення в агропромислові сектори економіки минулого року суттєво скоротилися і склали лише 53,3 \% відповідного показника 2019 року. Виокремлено чинники впливу на інвестиційну діяльність в аграрній сфері України загалом, а також у окремих аграрних підприємствах у 2020 році. Встановлено, що важливим аспектом інвестиційного забезпечення аграрних підприємств виступає інформація.
\end{abstract}

The article considers the essence of investments and key aspects of investment support of agricultural enterprises. It is established that an enterprise can achieve its goals only when its transformation meets the requirements and changes in the existing economic environment, which depends on its investment activities. It is determined that agricultural production today operates in extremely difficult conditions. It is proved that in 2020 the volume of capital investments in the agroindustrial sectors of the Ukrainian economy amounted to UAH 36 billion, investments in the agro-industrial sectors of the economy last year decreased significantly and amounted to only $53.3 \%$ of the corresponding figure for 2019 . Factors influencing investment activity in the agricultural sector of Ukraine as a whole, as well as in some agricultural enterprises in 2020 are highlighted. It is established that an important aspect of investment support of agricultural enterprises is information. It is advisable to disseminate information that is within the interests of investors. Leading positions are occupied by information on the general nature, territory and its investment opportunities: general economic indicators, the position of certain industries, specific data on economic entities - potential partners, and so on. It is imperative to provide potential investors with accurate, reliable information about investment opportunities. The key problem that slows down the development of agriculture and the expansion of its investment activities is, first of all, the lack of an investment-attractive climate in order to attract investment to the agro-industrial complex. In today's reality, Ukraine has significant opportunities to increase the volume of agricultural production, but to achieve these goals requires modern technology, improved material and technical base, all this is possible with investment. Summing up the results of the study, it should be emphasized that the effective investment activities of agricultural enterprises are the key to their successful development. In modern economic conditions, investment activity has become much more complicated, due to the variability of the external environment. Ukraine has a significant number of progressive and promising engineering developments of agricultural machinery, which in the absence of funding in practice are not performed. That is why it is necessary to pay special attention to improving the management of investment activities of agricultural enterprises, especially the development and justification for the implementation of investment projects. Investment support of the agricultural sector of the economy can be accelerated with a precise approach to identifying promising ways to use investment funds.

Ключові слова: аграрні підприємства, інвестичї, інвестичійне забезпечення, кредитування, інформачія, капітальні вкладення, капітал.

Key words: agricultural enterprises, investments, investment support, crediting, information, capital investments, capital.

\section{ПОСТАНОВКА ПРОБЛЕМИ}

Процес функціонування будь-якого підприємства є динамічним, адже він безперервно піддається змінам та розвитку. Підприємство може досягати поставлені перед собою цілі лише тоді, коли його трансформація відповідає вимогам та змінам існуючого економічного середовища, що залежить від пї інвестиційної 
діяльності. В сучасних умовах реформування суспільно-економічних відносин одним із пріоритетних умов стійкого функціонування $€$ цілковите використання всіх факторів розвитку економіки, включаючи інвестиційний процес. Надзвичайно важливими питання інвестиційного забезпечення є для аграрних підприємств, що характеризуються комплексом економічних, соціальних, бюджетних, екологічних і інших проблем, ефективне вирішення яких багато в чому пов'язане з активізацією найбільш перспективних напрямків інвестиційної політики. Формування та розвиток ринкових відносин в Україні спонукало до появи нових форм задоволення необхідності підприємств потрібними ресурсами для їх розвитку. Така ситуація спонукала до появи нових ринкових інститутів, ключовим з яких виступає інститут забезпечення інвестиційного. Часто вживаними стали дефініції "інвестиції", "інвестиційний процес", "інвестування", "інвестиційна діяльність", "інвестиційна політика", "інвестиційне забезпечення". Аослідженню сутності та ключових аспектів інвестиційного забезпечення аграрних підприємств присвячені роботи великої кількості вітчизняних та зарубіжних вчених та дослідників.

\section{АНАЛІЗ ОСТАННІХ ДОСЛІДЖЕНЬ І ПУБЛІКАЦІЙ}

Сутність та проблематику інвестиційного забезпечення аграрних підприємств досліджували у своїх працях такі вітчизняні та зарубіжні науковці: Кузьо Н., Аупенко Ю.О., Кустріч М.О., Макаров М.О., Кожемякіна М.Ю. та ін.

\section{META CTATTI}

Метою статті є дослідження ключових аспектів та пошук пріоритетних напрямів покращення інвестиційного забезпечення аграрних підприємств у сучасних умовах господарювання.

\section{ВИКЛАД ОСНОВНОГО МАТЕРІАЛУ}

Інвестиції посідають значне місце в економіці, оскільки без них забезпечення стабільного розвитку економіки та стійке економічне зростання є неможливим. Активний інвестиційний процес характеризує економічний потенціал країни взагалі, спонукає до зростання життєвого рівня населення. Економічна діяльність окремих суб'єктів господарювання залежить переважно від обсягів та форм залучених інвестицій. В умовах сьогодення значну увагу важливо звертати на роз- виток керування інвестиційною діяльністю аграрних підприємств, адже сільське господарство посідає ключове місце в економіці держави. Сільськогосподарська галузь покликана здійснювати раціональне та дієве використання ресурсів природних, наповнювати ринок продукцією продовольчою, а також забезпечити експорт товарів, що виробляються.

Аграрне виробництво сьогодні функціонує у надзвичайно складних умовах, на нього впливає здійснення бойових дій на Сході країни, в результаті чого знищено значну частину земель сільськогосподарського призначення, істотна девальвація національної валюти і галопуюча інфляція, є результатом збільшення витрат в декілька разів. Отже, враховуючи вищенаведене, безперервне дослідження інвестиційної діяльності аграрних підприємств, аналіз тенденцій інвестування в аграрне виробництво $є$ надзвичайно актуальним.

За твердженням Кожемякіної М.Ю.: "інвестиційне відродження аграрного сектору потребує залучення у виробництво таких інвестицій, які б забезпечували потребу в необхідних видах матеріально-технічних ресурсів і створювали умови для ефективної діяльності підприємств. Проте глибока криза в економіці України, особливо в аграрному секторі, яка тривала впродовж багатьох років, не тільки спричинила руйнівні процеси в матеріальнотехнічному забезпеченні, а й призвела до різкого скорочення трудових ресурсів, погіршення їх вікового складу, деградації земельних ресурсів, спаду сільськогосподарського виробництва" [1, с. 68-69].

Розглянемо більш детально визначення сутності інвестицій у різних літературних джерелах. Відповідно до Закону України "Про інвестиційну діяльність" інвестиції це: " всі види майнових та інтелектуальних цінностей, що вкладаються в об'єкти підприємницької та інших видів діяльності, в результаті якої створюється прибуток (доход) та/або досягається соціальний та екологічний ефект" [2].

За твердженням Макарова M.О.: "інвестиції у сільське господарство мають свої специфічні особливості. Вони проявляються в тому, що поряд з вкладенням капіталу в об'єкти результатів праці людини, як в інших галузях економіки, в сільському господарстві вони здійснюються ще і в об'єкти природи, що при інших рівних умовах робить їх діяльність більш капіталомісткою 3 тривалим терміном окупності та високими ризиками, оскільки 
АГРОСВIT № $7-8,2021$

природа живе за своїми законами, управління якими сьогодні або неможливо, або дорого" [3, с. 28].

У свою чергу Кустріч $\Lambda . О$. акцентує увагу на тому, що: "Аля організації залучення та освоєння інвестиційних ресурсів необхідно застосовувати методи регулювання, що спрямовані на підвищення ефективності інвестиційної діяльності, яка повинна відповідати відповідному рівню розвитку (циклу) національної економіки. Питання регулювання інвестиційної діяльності в сільському господарстві є ключовими в реалізації національних цілей та інтересів України. Вони переслідують рішення таких завдань. Аля держави: забезпечення сталого економічного зростання, підвищення добробуту та рівня життя населення за рахунок модернізації економіки і, відповідно, розширення інвестиційної діяльності, здійснення ефективного перетворення економічної системи країни з метою підвищення результативності та гнучкості їі інститутів, захист національних інтересів у зовнішньоекономічних відносинах" [4, с. 38].

У сучасних умовах господарювання аграрні підприємства потребують великих капітальних вкладень для накопичення доходу від своєї діяльності за такими ключовими напрямами: введення в дію приміщень тваринницьких, будівництво теплиць закритого грунту, будівництво оптово-роздрібних ринків продукції сільськогосподарської, рекультивація земель, будівництво заводів з альтернативних видів палива, будівництво елеваторів, будівництво комбікормових, силосних і сінажних споруд та iн.

Ключовою проблемою, котра сповільнює розвиток сільського господарства та розширення його діяльності інвестиційноӥ, виступає насамперед, проблематика відсутності інвестиційно-привабливого клімату з метою залучення інвестицій до АПК. У сьогоднішніх реаліях Україна має значні можливості нарощення обсягів виробництва продукції сільськогосподарської, але для реалізації поставлених цілей необхідними є сучасні технології, вдосконалена матеріально-технічна база, все це можливе за умов залучення інвестицій. Україна має значну кількість прогресивних та перспективних інженерних розробок техніки сільськогосподарської, котрі в умовах відсутності фінансування в практичній діяльності не виконуються. Також в Україні є велика кількість прикладів реалізації інноваційних технологій, котрі переважно кращі, навіть ніж у Европі. Але розпов-
Таблиця 1. Динаміка залучення капітальних інвестицій в сільське господарство України за 2015-2019 роки, млн грн

\begin{tabular}{|l|l|l|l|l|l|}
\multicolumn{1}{c|}{ Показник } & 2015 р. & 2016 p. & 2017 p. & 2018 p. & 2019 p. \\
$\begin{array}{l}\text { ке господарство, } \\
\text { го та надання }\end{array}$ & 29310 & 49660 & 63401 & 65059 & 58555 \\
$\begin{array}{l}\text { господарство та } \\
\text { отівлі }\end{array}$ & 789 & 777 & 767 & 980 & 549 \\
\hline господарство & 56 & 47 & 73 & 65 & 26 \\
\hline $\begin{array}{l}\text { сільське, лісове та } \\
\text { осподарство }\end{array}$ & 30155 & 50484 & 64243 & 66104 & 59130 \\
\hline
\end{tabular}

сюдження досвіду їх загального використання відсутнє через несприятливий клімат інвестиційний в країні, котрий перешкоджає припливу ресурсів інвестиційних, в умовах якого інвестори відмовляються здійснювати фінансування таких проектів. Важливим етапом у процесі інвестиційного забезпечення підприємства виступає аналіз стану інвестиційного забезпечення галузі.

3 метою оцінювання обсягів капітальних інвестицій в сільське господарство України в таблиці 1 проаналізуємо динаміку залучення капітальних інвестицій використовуючи офіційні статистичні дані.

Аналізуючи таблицю 1 варто зауважити, що на протязі 2015-2019 років реальні інвестиційні надходження до сільськогосподарської галузі мали тенденцію до збільшення. У 2019 році, в порівнянні з 2015 роком загальна сума капітальних інвестицій в сільське, лісове та рибне господарство збільшилась на 28975 млн грн або 196\%, така динаміка є сприятливою для розвитку аграрних підприємств.

За підсумками досліджень вчених Інституту аграрної економіки: "у 2020 році обсяги капітальних інвестицій в агропромислові сектори економіки України склали 36 млрд грн, капіталовкладення в агропромислові сектори економіки минулого року суттєво скоротилися і склали лише 53,3\% відповідного показника 2019 року. Індекси обсягів цих капітальних інвестицій за січень - грудень 2020 року до відповідного періоду попереднього року становлять по сільському господарству 54,7 \%, лісовому господарству - 65,5\%, рибному господарству - 53,6 \%, а також харчовій промисловості - 51,5 \%. Ці показники свідчать, що у 2020 році у агропродовольчих секторах економіки відбулася інвестиційна криза, глибина якої зіставна з 2009 роком, коли в умовах світової фінансово ї кризи капітальні інвестицї̈ у сільське господарство України скоротилися більш ніж наполовину. Інвестиційний спад по сільському господарству і харчовій промисло- 


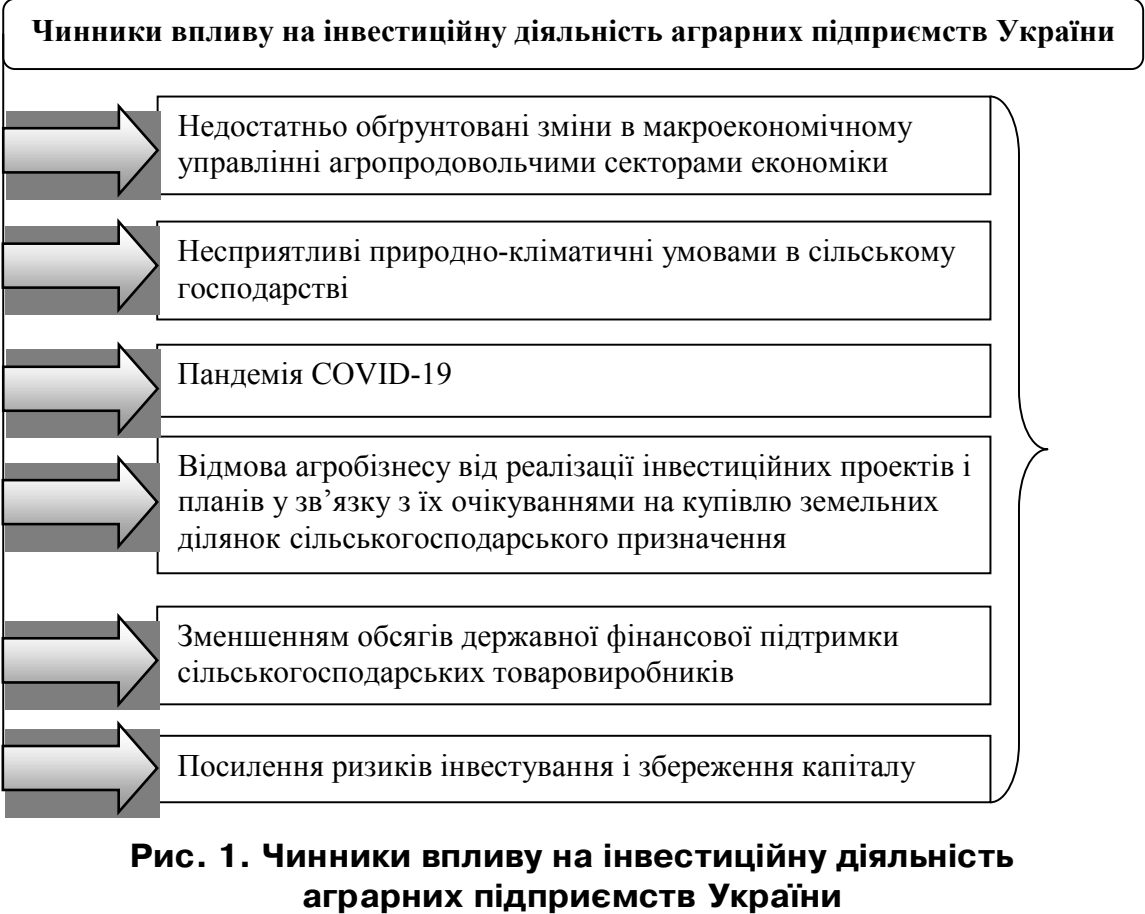

Ажерело: сформовано автором на основі [6].

вості в 2020 році був глибшим, ніж в інших секторах економіки, по яких індекс капітальних інвестицій склав 62,8 \%. Це означає, що відносини між видами економічної діяльності в економіці України торік змінювалися не на користь iii агропродовольчих секторів. Інвестиційна криза у сільському господарстві у 2020 році супроводжувалася скороченням обсягів виробництва сільськогосподарської продукції (мінус $11,5 \%$ ) і цін на неї (мінус 11,6 \%). Тому в 2021 році слід очікувати на посилення у сільськогосподарських товаровиробників дефіциту власних коштів на фінансування капітальних інвестицій. У зв'язку з цим їм будуть потрібні додаткові позикові й залучені кошти" [6].

Значний спад інвестиційної діяльності в аграрній сфері України в цілому, а також в окремих аграрних підприємствах у 2020 році пояснюється збільшенням негативного впливу певної кількості чинників, що представлені на рисунку 1.

Погіршення інвестиційної діяльності 2020 року негативно вплине на темпи розвитку економіки, на продовольчу безпеку держави, також на валютні і бюджетні надходження до держави.

На думку Аупенко Ю.О.: "основним джерелом інвестицій у сільськогосподарському виробництві залишаються власні кошти товаровиробників. Їхня частка, за оцінками науковців Інституту аграрної економіки, становить близько 70-80\%" [7].
Вагому роль в інвестиційному процесі відіграє стан засобів виробництва (рівень зношеності основних засобів) та коефіцієнти ефективності виробництва (рентабельність загальна на гривню собівартості, співвідношення прибутку до вартості продукції реалізованої, співвідношення прибутку до загальної суми активів, відношення прибутку до виробничих фондів та засобів оборотних). Саме ці показники генерують підгрунтя виробничого фактора привабливості інвестиційної, бо визначають фінальні показники фінансово-економічної діяльності аграрного підприємства.

Також інвестиційний процес тісно пов'язаний з станом ринку кредитного капіталу, а також із рівнем розвитку інфраструктури кредитно-фінансової. Аосить актуальною проблемою для аграрних підприємств є одержання банківського кредиту. Така ситуація спостерігається за рахунок високих вимог банків до питань кредитоспроможності, насамперед до застави, і самої процедури кредиту. Окрім того, більшість аграрних підприємств потребують довгострокового кредитування. Адже короткострокове кредитування вирішує проблеми одержання потрібних ресурсів з метою здійснення робіт польових, то кредити довгострокові виступають беззаперечною вимогою для розширення виробництва і оновлення фондів виробничих. Характерні особливості процесу технологічного в бізнесі аграрному характеризують ключову важливість довгострокового кредитування, а в умовах сьогодення в аграрних підприємств застава для залучення кредитних ресурсів довгострокових відсутня. Отже, одержання кредитів довгострокових під заставу землі та розвиток іпотечного кредитування повинно стати невід'ємним елементом ринку кредитно-фінансових послуг [8].

Також, не менш важливим аспектом інвестиційного забезпечення аграрних підприємств виступає інформація. Аоцільно розповсюджувати інформацію, котра $є$ в межах інтересів для інвесторів. Аідируючі позиції займає інформація про загальний характер, територію а також її інвестиційні можливості: показники загальноекономічні, становище певних галузей, конкретні дані стосовно господарюючих суб'єктів - ймо- 
вірних партнерів тощо. Обов'язковим є надання інвесторам потенційним точної, достовірної інформації про можливості інвестування.

\section{ВИСНОВКИ І ПЕРСПЕКТИВИ ПОДАЛЬШИХ РОЗВІДОК}

Підводячи підсумки проведеного дослідження варто наголосити на тому, що ефективна інвестиційна діяльність аграрних підприємств є запорукою їх успішного розвитку. У сучасних умовах господарювання інвестиційна діяльність в значній мірі ускладнилася, що обумовлено мінливістю зовнішнього середовища. Саме тому необхідно приділяти особливу увагу вдосконаленню управління інвестиційною діяльністю аграрних підприємств, передусім питанням розробки та обгрунтуванням для реалізації інвестиційних проектів. Інвестиційне забезпечення аграрного сектору економіки можливо прискорити за умов точного підходу відносно визначення перспективних шляхів застосування коштів інвестиційного призначення. За умов обмежених фінансових джерел інвестиційні ресурси важливо насамперед спрямовувати на розвиток тих напрямів виробництва, від котрих на даному етапі є можливість отримання найбільшого ефекту із меншим терміном окупності, а також тих, котрі направлені на розв'язання гострих проблем аграрних підприємств. Перспективним напрямом дослідження в подальших наукових роботах стане аналіз напрямів державного регулювання інвестиційного забезпечення аграрних підприємств.

Мітература:

1. Кожемякіна М.Ю. Інвестиційне забезпечення як основа розвитку аграрної економіки України. Економіка АПК. 2009. № 12. С. 68-73.

2. Про інвестиційну діяльність: Закон України від 18 вересня 1991 р. № 1560-XII / Верховна Рада України. URL: https://zakon.rada.gov.ua/laws/show/1560-12\#Text (дата звернення: 13.04.2021).

3. Макаров М.О. Особливості реалізацї̈ інноваційної політики на регіональному рівні. Інвестиції: практика та досвід. 2009. № 8 (квіт.). C. $27-29$.

4. Кустріч $\Lambda . О$. Особливості залучення інвестицій у сільське господарство: сучасний стан і тенденції розвитку. Інвестиції: практика та досвід. 2017. № 24. С. 37-42.

5. Статистичний щорічник України. 2019 : статистичний збірник / Аержавний комітет статистики України. Київ, 2020. 463 с.

6. У 2020 році в агропродовольчих секторах економіки відбулася інвестиційна криза, глиби- на якої співставна з 2009 роком. ННЦ "IAE": веб-сайт. URL: http://www.iae.org.ua/presscentre/archnews/3056-u-2020-rotsi-v-ahroprodovolchykh-sektorakh-ekonomiky-vidbulasyainvestytsiyna-kryza-hlybyna-yakoyi-spivstavna-z2009-rokom-mykola-kisil.html (дата звернення: 13.04.2021).

7. Аупенко Ю.О. Пожвавлення інвестиційної активності в АПК є інфляційним. URL: http://milkua.info/uk/post/pozvavlennainvesticijnoi-aktivnosti-v-apk-e-inflacijnim (дата звернення: 12.04.2021).

8. Кузьо Н. Філософія інвестицій в аграрний сектор. Агробізнес сьогодні. - URL: www.agrobusiness.com.ua/ event/1344 (дата звернення: 13.04.2021).

\section{References:}

1. Kozhemjakina, M. Ju. (2009), "Investment support as a basis for the development of the agricultural economy of Ukraine", Ekonomika APK, vol. 12, pp. 68-73.

2. The Verkhovna Rada of Ukraine (1991), The Law of Ukraine "About investment activity", available at: https://zakon.rada.gov.ua/laws/ show/1560-12\#Text (Accessed 13 April 2021).

3. Makarov, M. O. (2009), "Features of implementation of innovation policy at the regional level", Investytsii: praktyka ta dosvid, vol. 8, pp. 27-29.

4. Kustrich, L.O. (2017), "Features of attracting investment in agriculture: current status and development trends" Investytsii: praktyka ta dosvid, vol. 24, pp. 37-42.

5. State Statistics Service of Ukraine (2020), Statystychnyj shhorichnyk Ukrajiny. 2019 [Statistical Yearbook of Ukraine. 2019], Derzhkomstat, Kyiv, Ukraine.

6. National scientific center "Institute of agricultural economy" (2021), "In 2020 in the agri-food sectors of the economy there was an investment crisis, the depth of which is comparable to 2009", available at: http://www.iae.org.ua/presscentre/archnews/ 3056-u-2020-rotsi-v-ahroprodovolchykh-sektorakhekonomiky-vidbulasya-investytsiyna-kryza-hlybynayakoyi-spivstavna-z-2009-rokom-mykola-kisil.html (Accessed 13 April 2021).

7. Lupenko, Ju.O. (2015), "The revival of investment activity in the agro-industrial complex is inflationary", available at: http://milkua.info/ $\mathrm{uk} / \mathrm{post} /$ pozvavlenna-investicijnoi-aktivnosti-vapk-e-inflacijnim (Accessed 13 April 2021).

8. Kuzjo, N. (2012), "Philosophy of investment in the agricultural sector", Aghrobiznes sjoghodni, [Online], available at: www.agro-business.com.ua/ event/1344 (Accessed 13 April 2021).

Стаття надійшла до редакчї 15.04.2021 p. 
УAK 338.48

\author{
О. Ю. Красовська, \\ к. е. н., Аоцент, професор кафедри міжнародного маркетингу, \\ Університет імені Альфреда Нобеля
}

ORCID ID: 0000-0002-6981-2213

DOI: $10.32702 / 2306-6792.2021 .7-8.72$

\title{
СУЧАСНІ ОСОБЛИВОСТІ УПРАВАІННЯ МАРКЕТИНГОМ ПОС АУГ СУБ'ЄКТІВ ГОСПОААРЮВАННЯ СФЕРИ ТУРИЗМУ
}

\author{
O. Krasovska, \\ $\mathrm{PhD}$ in Economics, Associate Professor, Professor of the Department \\ of International Marketing, Alfred Nobel University in Dnipro
}

\section{MODERN FEATURES OF MARKETING MANAGEMENT OF SERVICES OF TOURISM BUSINESS ENTITIES}

Систематизовано сучасні особливості управління маркетингом послуг суб'єктів господарювання сфери туризму. Виділити характерні риси системного підходу при вивченні сучасних особливостей маркетингу послуг суб'єктів господарювання сфери туризму: цілісність як методологічний принцип; цілісна інтерпретація наукових знань як тенденція, успішно реалізується на практиці системних досліджень; розроблення проекту як завдання дослідження.

Аоведено, що ефективна управлінська Аіяльність, яка задовольняє вимоги системного підходу, в значній мірі визначається правильним розумінням управлінських функцій, в яких виявляється сутність і зміст управління. Важливо враховувати роль функцій під час формування організаційної структури управління, причому самі вони можуть бути реалізовані тільки структурованою системою.

У межах викладеного системного підходу уточнено визначення маркетингу. Встановлено, що відсутність визнання значення споживача в процесі сучасного маркетингу є недоліком в визначеннях його як Аіяльності, спрямованої на створення попиту. Хоча класичне визначення й охоплює собою всі сторони маркетингової діяльності, воно $є$ надто широким Аля цілей дослідження, тому запропоновано наступне визначення: маркетинг послуг суб'єктів госпоАарювання сфери туризму - це вид люАської Аіяльності, спрямований на задоволення потреб людей за допомогою туристичного обороту і отримання прибутку.

Визначено, що процес управління маркетингом послуг у сфері туризму на відміну від традиційної маркетингової Аіяльності повинен включати в себе етап визначення цілей удосконалення послуги. На відміну від традиційної маркетингової діяльності, яка грунтується на єдиній маркетинговій концепції, поліваріантність системи функцій туризму вимагає Аиференційованого підходу до вироблення конкретної стратегї̈ маркетингу.

The modern peculiarities of marketing management of services of tourism entities are systematized. Highlight the characteristics of a systematic approach in the study of modern features of marketing services of tourism entities: integrity as a methodological principle; holistic interpretation of scientific knowledge as a trend, successfully implemented in the practice of systems research; project development as a research task. It is proved that effective management activities that meet the requirements of a systems approach are largely determined by a correct understanding of management functions, which reveals the essence and content of management.

It is important to consider the role of functions in the formation of the organizational structure of management, and they themselves can be implemented only by a structured system. Within the limits of the stated system approach the definition of marketing is specified. It is established that the lack of recognition of the importance of the consumer in the process of modern marketing is a shortcoming in defining it as an activity aimed at creating demand, as a set of measures in the field of research and trade of the enterprise, to study all factors influencing production and promotion; services from producer to consumer or as a system of management of production and sales activities of the company, aimed at obtaining an acceptable amount of profit through accounting and active influence on market conditions. 
In addition, in the case of its use there is a methodological complication due to the inability to control the control system. Although the classical definition covers all aspects of marketing, it is too broad for the purposes of our study, so the following definition is proposed: marketing services of tourism entities is a type of human activity aimed at meeting people's needs through tourism turnover and obtaining profit.

However, in this formulation, this definition does not reflect the above features of the tourist systems and requires further specification. It is determined that the process of marketing management of services in the field of tourism, in contrast to traditional marketing activities, should include the stage of determining the goals of service improvement.

Unlike traditional marketing activities, which are based on a single marketing concept, the multivariate system of tourism functions requires a differentiated approach to developing a specific marketing strategy.

Ключові слова: маркетингова конщепиія, суб'єкт господарювання, сфера туризму, управління маркетингом послуг.

Key words: marketing concept, business entity, tourism sphere, service marketing management.

\section{ПОСТАНОВКА ПРОБЛЕМИ}

3 початком реформування економіки $\mathrm{V}_{\mathrm{K}}$ раїни відбулися зміни, що зачіпають всі напрями діяльності, які мали істотний вплив на процес управління суб'єктами господарювання. Спостерігається зростання конкурентної боротьби, що вимагає залучення значного обсягу фінансових ресурсів з метою створення конкурентоспроможних продуктів і послуг. Відсутність фінансових коштів ускладнюється обмеженістю можливостей бюджетного фінансування і недоступністю його для суб'єктів господарювання. Водночас інвестиції, спрямовані на створення нових продуктів і послуг, можуть не окупитися зовсім, або окупитися тільки після закінчення тривалого періоду, що є істотним чинником, що стримує інвестиційну активність.

Отже, основною перевагою сфери туризму Аля потенційних інвесторів стає можливість швидкого отримання прибутку, а не перспектива впливу на свідомість потенційних споживачів у бажаному для інвестора напрямі з метою збільшення майбутніх доходів. Зазначена можливість визначається кількістю споживачів тієї чи іншої послуги і всього туристичного каналу в цілому. Тим самим інвестиційна привабливість суб'єктів господарювання, а значить, i ïх конкурентоспроможність знаходяться в залежності від обсягу їх споживання.

Необхідність підвищення рівня конкурентоспроможності суб'єктів господарювання сфери туризму, забезпечення зростання їх фінансових надходжень, раціонального здійснення і конкретизації етапів їх діяль- ності по залученню додаткової кількості споживачів вимагає науково обгрунтованого формування системи управління маркетингом послуг, забезпечення раціонального взаємодії їі окремих елементів на базі реалізації вимог системності до аналізу розглянутого об'єкта.

Актуальність поставлених у статті проблем зростає в зв'язку з триваючим процесом ринкових перетворень в економіці, відсутністю налагодженого механізму фінансування суб'єктів господарювання сфери туризму.

\section{АНАЛІЗ ОСТАННІХ ДОСЛІДЖЕНЬ І ПУБЛІКАЦІЙ}

Особливості управління маркетингом висвітлюються в працях провідних західних та вітчизняних економістів: Т. Амблера, Р. Блекуелла, П. Аойля, Аж. Еванса, К.А. Келлера, Ф. Котлера, М. Портера, Е. Райса, Ч. Сенділжа, Г. Чармесона, І.Амитрієва, О. Зборовської, I. Мельник, Г. Петренко, А. Череп та ін.

У дослідженнях зарубіжних і українських науковців теоретико-методологічні аспекти маркетингової діяльності посідають чільне місце, однак питання визначення сучасних особливостей управління маркетингом послуг суб'єктів господарювання сфери туризму висвітлено недостатньо повно.

\section{META CTATTI}

Мета статті - систематизація сучасних особливостей управління маркетингом послуг суб'єктів господарювання сфери туризмy. 


\section{ВИКЛАД ОСНОВНОГО МАТЕРІАЛУ ДОСЛІДЖЕННЯ}

Конкуренція в туристичній сфері призводить до зменшення кількості споживачів послуг конкретного суб'єкта господарювання, що робить негативний вплив на його фінансовий результат. Це в свою чергу призводить до істотного скорочення обсягів ресурсів, що знаходяться в розпорядженні даної організаційноправової структури та необхідних для створення нових продуктів і послуг. Зазначене тягне за собою зменшення маркетингових можливостей суб'єктів господарювання щодо задоволення потреб. У зв'язку з цим все більш актуальним стають методологічні та методичні рішення по створенню та ефективному функціонуванню системи управління маркетингом послуг суб'єктів господарювання сфери туризму, що дозволяє забезпечити як зростання кількості ïx споживання, так і збільшення фінансових надходжень на базі раціонального взаємодії окремих структурних елементів керуючої системи і диференційованого маркетингу стосовно різних видів продуктів і послуг.

Водночас методологічні та методичні положення формування, функціонування та розвитку системи маркетингу послуг у сфері туризму в умовах економічної та фінансової кризи в науковій літературі розроблені недостатньо [1;2]. Існує необхідність створення таких теоретичних і методичних положень системи управління маркетингом, взаємодії окремих їі елементів, які могли б скласти її основу.

Створення методологічних і методичних основ раціональної взаємодії функцій управління, здійснюваних у процесі розробки і реалізації програмних заходів, вироблення критеріїв їх ефективності, визначення стратегічних орієнтирів розвитку маркетингу окремих видів продуктів і послуг, оптимізація організаційноекономічної структури управління маркетингом також вимагають свого вирішення. Сучасний етап у вивченні систем туризму вимагає узагальнення та синтезу отриманих знань, що характеризують його функціональну і організаційно-економічну структуру.

У міру накопичення інформації відчувається нагальна потреба в її систематизації і інтеграції за допомогою теоретичної схеми, яка допомогла б виявити основні фактори, що впливають на ефективність діяльності суб'єктів господарювання сфери туризму. Але для вироблення такої схеми і розуміння механізму функціонування туризму, потрібно використовувати системний підхід, який сьогодні став загальновизнаним в науці. Аля вирішення такого зав- дання доводиться досліджувати не тільки властивості окремих елементів, але і їх взаємозв'язок і взаємодію.

Можна виділити наступні характерні риси системного підходу при вивченні сучасних особливостей маркетингу послуг суб'єктів господарювання сфери туризму [3]. По-перше, цілісність як методологічний принцип. Системний підхід передбачає рух від системи до иї компонентів, оскільки сума властивостей компонентів не тотожна властивостям системи в цілому. Туристична система являє собою певне цілісне утворення, всі компоненти якого пов'яЗані один з одним, причому зміни одного компонента закономірно тягнуть за собою зміни інших, тому туризм як система повинен бути пояснений не тільки через його компоненти, але також і через всю сукупність зв'язків між ними. По-друге, цілісна інтерпретація наукових знань як тенденція, успішно реалізується на практиці системних досліджень. Аослідження туризму часто описують та інтерпретують одні й ті ж явища, хоча і в різних категоріях, що робить можливим виділення еквівалентних понять і схем опису та інтерпретації. По-третє, розроблення проекту як завдання дослідження. Системний підхід дозволяє виділити ті відсутні ланки в вивченні об'єкта, які повинні бути заповнені, щоб чітко уявити його загалом. Aле головне, що він допомагає побачити тенденції розвитку і тому, не замикаючись у рамках сьогодення, спрямований у майбутнє.

Системний підхід передбачає визначення і попередню перевірку безлічі альтернативних варіантів досягнення цілей і довгострокових наслідків реалізації кожного варіанту. В рамках системного підходу виділяються основні елементи системи управління: цілі, функції, принципи, методи, структура управління, процеси управління, дослідження яких дозволяє здійснити вдосконалення системи управління, як продовження іiї функціонування та особливу стадію динаміки [4].

Системний підхід орієнтований на досягнення цілей системи на основі вибору і реалізації можливих варіантів рішень, отриманих в результаті обліку та аналізу всієї сукупності факторів, які так чи інакше впливають на управлінську діяльність, їх взаємовідносини. Сутність системного підходу полягає в розширенні можливостей раціонального управління соціальними процесами в умовах ускладнення зв'язків і взаємодій головним чином завдяки тому, що він створює більш сприятливі передумови прийняття рішень в кожному конкретному випадку з урахуванням всієї специфіки си- 
туації і з розумінням наслідків цих рішень. Він дозволяє в разі необхідності своєчасно оцінити стан системи і уточнити ї̈ цілі.

На думку автора, ефективна управлінська діяльність, яка задовольняє вимоги системного підходу, в значній мірі визначається правильним розумінням управлінських функцій, в яких виявляється сутність і зміст управління. Важливо враховувати роль функцій при формуванні організаційної структури управління, причому самі вони можуть бути реалізовані тільки структурованою системою. Вивчення функцій управління становить основну передумову раціональної побудови конкретної організаційної структури управління будь-якої соціальної системи, в тому числі системи управління маркетингом, визначення компетенції структурних підрозділів і відносин субординації (підпорядкованості). Місце, займане цією категорією в системі управління можна представити у вигляді логічної послідовності: цілі завдання - функції - структура. Тут функції виконують роль засобів, що забезпечують досягнення основних цілей системи [5].

У науковій літературі існують різні визначення функцій управління [6; 7]. Принциповими є два підходи, перший з яких розглядає функції в якості певних стадій процесу управління, а другий розуміє їх як види чи напрями управлінської діяльності. В рамках першого підходу послідовність операцій, що здійснюються суб'єктом управління, розчленовується на певні етапи, що слідують один за одним поки даний управлінський цикл не завершиться. Кожна з цих стадій має відносну самостійність, причому будь-яка попередня стадія є необхідною передумовою подальшої.

У межах викладеного системного підходу необхідно уточнити визначення маркетингу. У сучасній літературі існує ряд визначень маркетингу, які розглядають різні аспекти цього явища. Практично кожен автор формулює власне визначення, що тягне за собою появу методологічних проблем при вивченні даної сфери діяльності. Аослідники відзначають, що загальноприйнятого визначення маркетингу не існує [8]. Так, маркетинг визначають як сукупність організаційно-технічних і комерційних функцій підприємства по вивченню ринку, виробництву продукції з урахуванням ринкового попиту і просування товарів споживачеві [9]. Згідно 3 іншим визначенням маркетинг - це цілісна філософія, стратегія і тактика організації та управління виробничою і комерційною діяльністю підприємства та його численних посередників, спрямована на задоволення конкретних потреб окремих споживачів і конкретних груп, на шляху просування товару на ринок. В цьому випадку маркетинг розуміється як принципово нова філософія виробництва [10].

Обидва ці визначення охоплюють собою всі сторони функціонування суб'єкта господарювання в чому, на думку автора, полягає їх недолік, оскільки в цьому випадку незрозуміла відміна маркетингу від процесу підприємницької діяльності загалом. Таке широке трактування маркетингової діяльності тягне за собою виникнення термінологічних труднощів під час дослідження функціонування конкретних об'єктів.

Важливий аспект сучасного маркетингу, що полягає у необхідності задоволення потреб споживачів в результаті діяльності суб'єкта господарювання, відображений в його визначенні як концепції управління, процесу планування, встановлення цін, просування і поширення ідей, товарів і послуг, які формують такий характер діяльності виробників, який би найкращим чином задовольняв організації, споживачів і окремих особистостей в результатах їх праці [11], а також як комплексної системи організації виробництва і збуту продукції, орієнтованої на задоволення потреб конкретних споживачів і отримання прибутку на основі дослідження і прогнозування ринку, вивчення внутрішнього і зовнішнього середовища підприємства, розробки стратегії і тактики поведінки на ринку за допомогою маркетингових програм [12].

Однак розуміння маркетингу як концепції управління не є обгрунтованим, оскільки концепція управління може, на думку автора, видозмінюватися залежно від виду виробленої продукції або надання послуг, а розуміння маркетингу як системи організації виробництва не відповідає методологічному змісту даного поняття. На думку автора, відсутність визнання значення споживача в процесі сучасного маркетингу є недоліком у визначеннях його як діяльності, спрямованої на створення попиту [11], як комплексу заходів у сфері досліджень торговельно-збутової діяльності підприємства, по вивченню усіх чинників, що впливають на процес виробництва і просування товарів і послуг від виробника до споживача [10] або як системи управління виробничо-збутовою діяльністю компанії, спрямованої на отримання прийнятної величини прибутку за допомогою обліку та активного впливу на ринкові умови [7]. Крім того, в разі його використання виникає методологічне ускладнення, обумовлене неможливістю керувати системою управління. 
На думку автора, жодне з зазначених визначень не відображає сутності такого явища як маркетинг. Тому слід прийняти в якості базового класичне визначення, згідно з яким маркетинг - це вид людської діяльності, спрямованої на задоволення потреб за допомогою обміну [2]. Таке визначення є більш обгрунтованим, ніж близьке йому визначення, згідно 3 яким маркетинг - це передбачення, управління, і задоволення попиту на товари, послуги, організації, людей, території і ідеї за допомогою обміну [1], оскільки надає першочергового значення потреб і потреб людей. Однак і класичне визначення маркетингу має один істотний недолік, оскільки не відображає необхідність отримання прибутку в результаті маркетингової діяльності, що є однією з їі основних цілей [5].

Крім того, хоча класичне визначення й охоплює собою всі сторони маркетингової діяльності, воно $є$ надто широким для цілей нашого дослідження, тому автор пропонує таке визначення: маркетинг послуг суб'єктів господарювання сфери туризму - це вид людської діяльності, спрямований на задоволення потреб людей за допомогою туристичного обороту і отримання прибутку. Однак у такому формулюванні це визначення не відображає вищевказаних особливостей діяльності туристичних систем і вимагає подальшої конкретизації.

Нині термін "управління маркетингом" у діяльності українських суб'єктів господарювання сфери туризму не знаходить свого застосування, що зумовлено відсутністю наукового уявлення про роль і значення маркетингу для досягнення поставлених цілей. Водночас окремі компоненти маркетингу в їх роботі, безумовно, присутні, але відсутність системності та наукової бази при реалізації маркетингових за своєю сутністю заходів негативно відбивається, на думку автора, на фінансовому результаті діяльності суб'єктів господарювання.

На відміну від традиційної маркетингової діяльності, за якої підприємство орієнтоване на конкретні ринкові сегменти, що пред'являють в цілому однотипні вимоги щодо Якості продукції або послуг, суб'єкт господарювання сфери туризму взаємодіє з двома видами споживачів: посередниками і населенням, вимоги яких в значній мірі протилежні. Аля населення туризм $є$ засобом задоволення певного набору потреб, причому різні потреби задовольняються різними видами послуг, а посередники (в нашому прикладі - авіа або автотранспортні компанії) перешкоджають цьому, втручаючись у процес сприйняття туристичної програми.

Хоча посередники при певних умовах можуть самі виступати в якості засобу задоволення певних потреб представників споживання, втручання в зазначений процес є для споживачів негативним фактором і може привести до відмови від такої програми, що буде аналогічно переходу споживача до використання продукції або послуг підприємства-конкурента при традиційній маркетинговій діяльності. Отже, для збільшення кількості споживачів маркетингова служба повинна оптимізувати послуги авіа або автотранспортної компанії. У класичному випадку обсяг попиту або пропозиції на конкретний товар або послугу визначається їх ціною за умови, що інші фактори залишаються незмінними, тоді як послуги перевізника роблять визначальний вплив на їх ціну. У цьому проявляється діалектичний характер маркетингової діяльності в сфері туризму: 3 одного боку, суб'єкти господарювання реалізують транспортну послугу, ціна якої залежить, передусім від інтересу туриста, а з іншого боку, зацікавлені в залученні додаткової кількості споживачів, які негативно ставляться до даної транспортної компанії, але якщо реалізація можливостей перевезення проводитися не буде, то суб'єкт господарювання не зможе покрити витрати по здійсненню перевезення. Використання діалектики, як вчення про суперечливість буття і діалектичного методу при аналізі даних явищ виправдовується тим, що цей метод $є$ істотним компонентом будьякого наукового методу [3], що дозволяє більш повно і адекватно встановити сутність аналізованих об'єктів і їх взаємодії.

На думку автора, процес управління маркетингом послуг у сфері туризму на відміну від традиційної маркетингової діяльності повинен включати в себе етап визначення цілей удосконалення послуги. На відміну від традиційної маркетингової діяльності, яка грунтується на єАиній маркетинговій концепції, поліваріантність системи функцій туризму вимагає диференційованого підходу до вироблення конкретної стратегії маркетингу. Попри те, що діяльність туристичної компанії, як і будь-якого іншого суб'єкта підприємницької діяльності, підпорядкована отриманню прибутку, особливості продуктів і послуги вимагають використання різних маркетингових концепцій, а отже, диференційованого підходу до визначення цілей випуску такої послуги, що в свою чергу буде визначати зміну маркетингової стратегії для даного виду продуктів і послуг. 


\section{ВИСНОВКИ}

Отже, можливості використання існуючих маркетингових концепцій в діяльності суб'єктів господарювання полягають у такому. По-перше, використання маркетингової концепції інтенсифікації підприємницьких зусиль можливе в тому випадку, коли для суб'єкта господарювання не $є$ істотним реакція споживачів на зазначений вид продуктів і послуг. У цьому випадку мета удосконалення продуктів та послуги полягає в тому, щоб зібрати максимальну кількість споживачів, а завдання маркетингу - спонукати представників цільового сегмента споживання переглянути цю послугу. Така концепція, хоча і не відповідає сучасним уявленням про маркетингову діяльність, проте, є цілком припустимою, наприклад, для імпорту інфляції і екологічного збитку, які більшість українських споживачів сприймають як негативне явище сучасного туризму.

По-друге, маркетингова концепція вдосконалення виробництва вимагає мінімізації витрат на виробництво послуги. Мета удосконалення послуги - забезпечити досягнення певного рівня споживання при фіксованих витратах на виробництво послуги. Ця концепція на початку 90-х років активно використовувалася українськими туристичними компаніями під час організації численних туристичних послуг, витрати на виробництво яких були мінімальні. В даний час вона знаходить своє застосування при реалізації численних турів, які при значних обсягах сезонного споживання мають меншу вартість.

По-третє, використання маркетингової концепції вдосконалення товару і послуг має велике значення в сучасних умовах конкурентної боротьби. Мета удосконалення послуги в цьому випадку - перевершити послуги інших туристичних операторів за певними параметрами. Під час використання ціє̈̈ концепцї̈ особлива важлива взаємодія між маркетинговою службою та іншими підрозділами.

По-четверте, традиційна маркетингова концепція, в основі якої лежить баланс між інтересами споживачів і туристичної компанії, знаходить своє активне застосування останнім часом. Мета удосконалення послуги при її використанні - максимальне задоволення потреб споживачів. Перспективним напрямом у розвитку цієї концепції є розвиток сільського туризму, завдяки якому туристи зможуть втручатися в хід будь-якої послуги, змінюючи 11 спрямованість і вибираючи інші варіанти розвитку села, що стримується проте еконо- мічною неефективністю такої послуги в сучасних економічних умовах, яка передбачає збільшений обсяг фінансових ресурсів на $\dddot{1}$ підготовку і здійснення.

\section{$\Lambda$ ітература:}

1. Разінькова М.Ю. Етапи проведення маркетингового планування в ресторанному бізнесі. Економіка та держава. № 2. 2020. С. 62-66. URL: http://www.economy.in.ua/pdf/ 2_2020/13.pdf.

2. Аобрянська Н.А., Стоянова-Коваль С.С., Ніколюк О.В. Реалії сьогодення та перспективи розвитку туристичного бізнесу Одеської області. Економіка харчової промисловості. 2018. $10(1), 9-15$.

3. Нікольчук Ю.М. Готельно-ресторанний бізнес: сучасний стан, фінансове забезпечення, інвестиційна привабливість та перспективи подальшого розвитку в Україні. Бізнес Iнформ. № 5. 2020. C. 218-226. URL: http:// www.businessinform.net/export_pdf/business inform 2020 5_0 pages 218_226.pdf

4. Горішевський П., Васильєв В., Зінько Ю. Сільський зелений туризм: організація надання послуг гостинності. Івано-Франківськ: Micto HB, 2003. 148 c.

5. Котлер Ф. Маркетинг. Гостиприимтво. Туризм: Учеб. Аля студентов вузов / Ф. Котлер, Аж. Боуен, Аж. Мейкенз, гл. ред. Н.А. Эриашвили; пер. с англ. В.Н. Егорова. 2-е изА., перер. и доп. М.: ЮНИТИ, 2002. 1063 с.

6. Гузенко Г.М. Управління та вдосконалення маркетингової діяльності на підприємстві. Економіка і суспільство. 2017. № 12. С. 227-234.

7. Мілінчук О.В., Горшкова А.О. Зарубіжний досвід туристичного районування: приклад Болгарії. Причорноморські економічні студії. Вип. 52-1. 2020. С. 41-48.

8. Панкрухин А.П. Маркетинг территорий. 2-е изд., дополн. СПб.: Питер, 2006. 416 с.

9. Краус К.М. Управління маркетингом малого торговельного бізнесу: концепції, організація, домінанти розвитку: [монографія]. Полтава: Аивосвіт. 2013. 163 с.

10. Тульчинська С.О., Сегеда Е.І. Нові технології та їх вплив на сучасні методи маркетингу, що застосовуються на підприємстві. Сучасні проблеми економіки і підприємництво. 2015. Вип. 16. С. 98-104.

11. Матвієнко Н., Матвієнко В. Чинники розвитку туризму в Хорватії. Вісник Київського національного університету імені Тараса Шевченка. Географія. № 3 (72). 2018. С. 81—88. URL: https://visnyk-geo.knu.ua/wp-content/ uploads/2019/02/\%d0\% 2_81-88.pdf 
12. Gryshova I., Shabatura T., Nikoliuk O. Аержавне регулювання екотуризму в контексті Європейського досвіду. Наукові записки Інституту законодавства Верховної Ради України, 2020 (1), 126-136. Retrieved i3 https://instzak.com/index.php/journal/article/view/1783

\section{References:}

1. Razinkova, M. (2020), "Stages of marketing planning in restaurant business", Ekonomika ta derzhava, vol. 2, pp. 62-66, available at: http:// www.economy.in.ua/pdf/2 2020/13.pdf (Accessed 17 March 2021).

2. Dobryanska, N.A. Stoyanova-Koval, S.S. and Nikolyuk, O.V.(2018), "Realities of the present and prospects of development of tourist business of Odessa region", Economics of the food industry, vol. 10 (1), pp. 9-15.

3. Nikol'chuk, Yu.M. (2020), "Hotel and Restaurant Business: Current Status, Financial Provision, Investment Attractiveness and Prospects for Further Development in Ukraine", Biznesinform, vol. 5, pp. 218-226, available at: http://www.businessinform.net/export_pdf/businessinform20205_0pages218_226.pdf (Accessed 17 March 2021).

4. Gorishevsky, P. Vasyliev, E. and Zinko, U. (2003), Silsky zeleny turizm: organizaciya nadanya poslug gostinnosty [Rural green tourism: organization of hospitality services], Misto NV, Ivano-Frankivsk, Ukraine.

5. Kotler, F. Bouyen, Dzh. Meykenz, Dzh. and Eriashvili, N.D. (2002), Marketing. Gostipriimtvo. Turizm [Marketynh. Hostypryymtvo. Turyzm], 2nd ed., YUNITI, Moscow, Russia.

6. Huzenko, H.M. (2017), "Management and improvement of marketing activities at the enterprise", Ekonomika i suspil'stvo, vol. 12, pp. 227-234.

7. Milinchuk, O.V. and Gorshkova, L.O. (2020), "Foreign experience of tourist zoning: the example of Bulgaria", Prichornomorsky ekonomichny stydii, vol. 52-1, pp. 41-48.

8. Pankrukhin, A.P. (2006), Marketing territoriy, [Territory marketing], 2nd ed., SPb, Puter, Russia.

9. Kraus, K.M. (2013), Upravlinnia marketynhom maloho torhovel'noho biznesu: kontseptsii, orhanizatsiia, dominanty rozvytku [Marketing management of small business: concepts, organization, dominants of development], Dyvosvit, Poltava, Ukraine.

10. Tul'chyns'ka, S.O. and Seheda, Ie.I. (2015), "New technologies and their impact on modern marketing methods used in the enterprise", Suchasni problemy ekonomiky i pidpryiemnytstvo, vol. 16, pp. 98-104.
11. Matvienko, N. and Matvienko, V. (2018), "Factors in tourism development in Croatia", Visnyk Kyivskogo nacionalnogo universitetu imeny Tarasa Shevchenk. Geografia, vol. 3 (72), pp. $81-88$, available at: https://visnyk-geo.knu.ua/wp-content/u ploads/ 2019/02/\%d0\% 2_81-88.pdf (Accessed 17 March 2021).

12. Grishova, I.Yu. Shabatura, T.S. and Nikolyuk, O.V. (2020), "State regulation of ecotourism in the context of the European experience", Scientific Notes of the Institute of Legislation of the Verkhovna Rada of Ukraine, vol. (1), pp. 126136. https://doi.org/10.32886/instzak.2020.01.13 Стаття надійшла до редакиї̈ 17.04.2021 p.

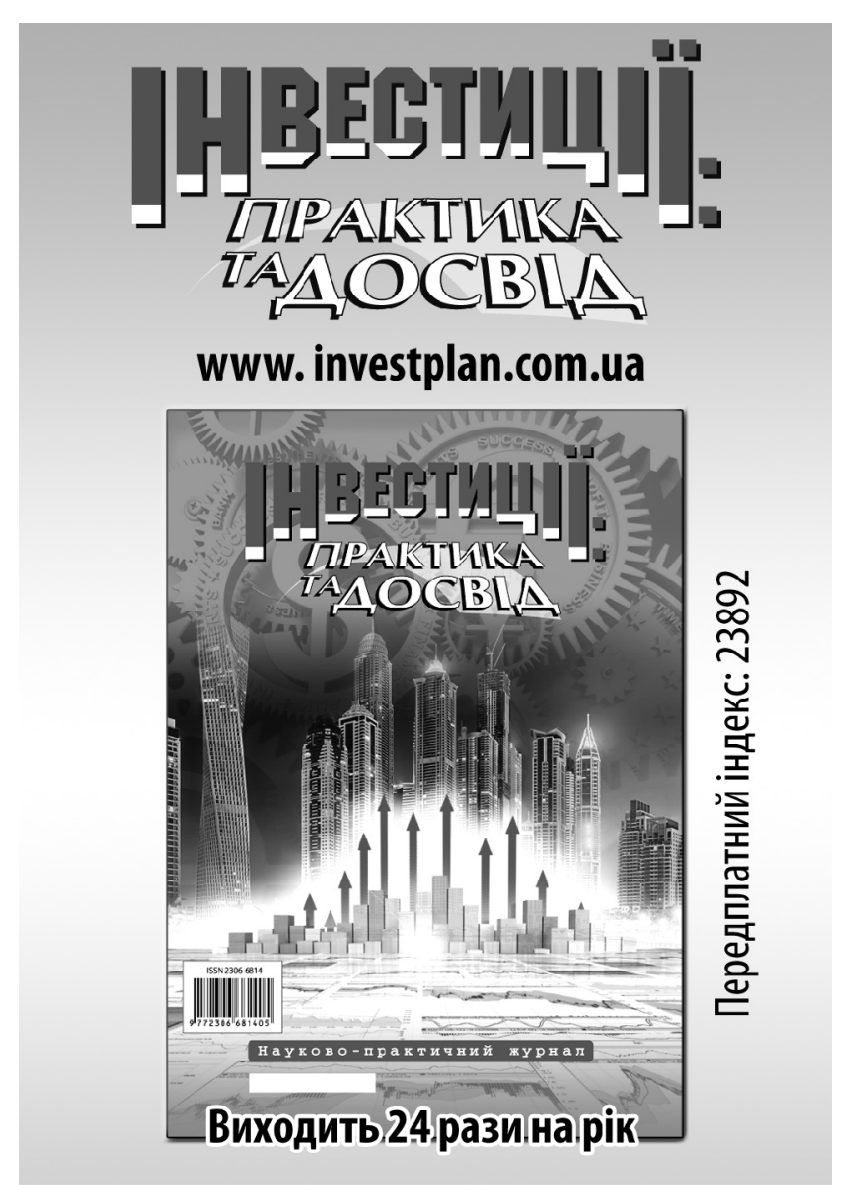

Журнал включено до переліку наукових фрахових видань України (Категорія «Б») 3

ЕКОНОМІЧНИХ НАУК та ДЕРХАВНОГО УПРАВЛІННЯ

(Наказ Міністерства освіти і науки України № 886 від 02.07.2020)

Спеціальності - 051, 071, 072, 073, 075, 076, 281, 292 


\title{
В.В. Ратинський,
}

к. е. н., старший викладач кафеАри бухгалтерського обліку та аудиту,

Тернопільський національний технічний університет імені I. Пулюя

ORCID ID: 0000-0001-9283-6371

DOI: $10.32702 / 2306-6792.2021 .7-8.79$

\section{БУХГААТЕРСЬКИЙ ОБАІК У ПРОЦЕСІ УПРАВАІННЯ ПІАПРИЕМСТВОМ}

\author{
V. Ratynskyi, \\ $\mathrm{PhD}$ in Economics, Senior Lecturer of the Department of Accounting and Audit, \\ Ternopil I. Puluj National Technical University
}

\section{ACCOUNTING IN THE ENTERPRISE MANAGEMENT PROCESS}

\begin{abstract}
Необхідність здійснення комплексних заходів щодо вдосконалення Аіючої системи бухгалтерського обліку та звітності викликана насамперед зміною економічного середовища діяльності господарюючих суб'єктів, розширенням взаємовідносин з суб'єктами світового ринку, появою нових об'єктів підприємницької діяльності, змінами правової бази. Теорія як система основних положень і ідей в тій чи іншій галузі знання - основа будь-якої науки і, по суті, головне ії зміст. Функцією науки, що представляє собою сферу людської діяльності, є вироблення і теоретична систематизація об'єктивних знань про предмет наукового дослідження. Більшість видів інтелектуальної діяльності, щоб вважатися наукою, повинні мати свою теоретичну основу. Ао їх числа належить облік, економічний аналіз і аудит. Нині більш-менш грунтовно розробленою вважається теорія бухгалтерського обліку та аналізу господарської Аіяльності, хоча і тут багато що потрібно переосмислити і розвинути стосовно можливостей сучасних інформаційних технологій і умов здійснення виробничо-фінансової діяльності підприємств зараз і в майбутньому.
\end{abstract}

The need for comprehensive measures to improve the existing system of accounting and reporting is primarily due to changes in the economic environment of economic entities, expanding relations with world market participants, the emergence of new business objects, changes in the legal framework. Theory as a system of basic principles and ideas in a particular field of knowledge - the basis of any science and, in fact, its main content. The function of science, which is a sphere of human activity, is the development and theoretical systematization of objective knowledge about the subject of scientific research. Most intellectual activities, to be considered a science, must have a theoretical basis. These include accounting, economic analysis and audit. Currently, more or less thoroughly developed is the theory of accounting and analysis of economic activity, although here much needs to be rethought and developed in relation to the capabilities of modern information technology and the conditions of production and financial activities of enterprises now and in the future.

For the proper functioning of any market link economy, it is essential that participants, when making decisions, have truthful and objective information about property, financial and financial condition, results of work - profits, income or losses, as well as the features of their achievement (based on preliminary data) as in their enterprise, and partners. Such information is provided only by the accounting system.

Accounting is used in all areas of business - production, commercial, banking, insurance, in all industries and subsectors - industry, agriculture, construction and more. In each sphere (type) of activity, in each branch of management accounting has specific features. However, the initial provisions of accounting are the same, common to all activities and in all sectors of the economy. Accounting as an information system is divided into open, such that can be published, and closed, which is a trade secret of the enterprise. The first forms the concept of financial accounting, the second - internal (managerial, production) accounting. As for the initial provisions, they are common, common to both financial and internal accounting.

Ключові слова: теорія обліку, бухгалтерський облік, аудит, управління бізнесом, бізнесрішення, методи обліку, стратегічне планування та облік, облікова освіта.

Key words: accounting theory, accounting, audit, business management, business decisions, accounting methods, strategic planning and accounting, accounting education.

\section{META CTATTI}

Метою статті є розгляд проблемних питань теорії бухгалтерського обліку в історичному розвитку, а також пропозицію можливих шляхів їх вирішення. Зроблено основний висновок про необхідність відокремленої теорії бухгалтерського обліку і їі основних постулатів, що включають певні поняття, зміст та 
сферу функціонування обліку для внутрішнього управління діяльністю підприємств, методи бухгалтерського обліку та аудиту.

\section{МЕТОДОЛОГІя}

Методологічною основою стали наукові праці вітчизняних і зарубіжних вчених. У процесі написання статті використовувалися методи порівняння, індукції, дедукції, аналізу, синтезу.

\section{АНАЛІЗ ОСТАННІХ ДОСЛІДЖЕНЬ І ПУБЛІКАЦІЙ}

Сучасні тенденції розвитку бухгалтерського обліку і звітності в чому визначені прагненням подолати основні недоліки бухгалтерського обліку, які відзначаються і відзначалися такими вітчизняними та зарубіжними вченими: Івашкевич В.Б., Богатая I.Н., Евстафєва Е.М., Канцедал Н.А., Краус Н.М., Голобородько О.П., Павликівська О.І., Семенишена Н., Шишкова Н.А., Яструбський М.Я. і ін.

\section{ВИКЛАД ОСНОВНОГО МАТЕРІАЛУ}

Теорія бухгалтерського обліку, як система і основа практики його застосування, стала формуватися порівняно недавно і знаходиться в початковій стадії свого розвитку. Якщо першим, судячи зі збережених в історії публікацій, методологічних питань бухгалтерського обліку близько семи століть, то теорія бухгалтерського обліку в її сучасному розумінні не налічує i сімдесяти років. Аеякі їі поняття, методи і процедури (наприклад, рекомендації про необхідність щоденного обліку витрат сировини, матеріалів та інших ресурсів, угруповання витрат в залежності від ступеня їх змінності від величини визначального фактора, розрахунок точки нульового прибутку, ідеї стандарт-коста та нормативного обліку) з'явилися раніше цього терміну, проте як система, вид відокремленого обліку, навчальна дисципліна для викладання в нашій країні сформувався лише до кінця XX ст. Трохи раніше це відбулося за кордоном $[3 ; 8 ; 9]$.

Бухгалтерський облік спочатку призначався для господаря-власника закладу і служив його інтересам. Тільки в середні віки держави Європи оцінили можливості бухгалтерського обліку для оподаткування і стали вводити єдині регламентовані законодавчі правила організації і ведення справ в бухгалтерії підприємств. Це стосувалося обов'язковості первинного документування, єдиних правил оцінки і списання активів, визначення фінансових результатів діяльності та необхідності підтвердження даних бухгалтерської звітності незалежним аудитором. Бухгалтерський облік і звітність все більшою мірою стали орієнтуватися на зовнішніх споживачів (інвестори, кредитні установи, статистичні та податкові органи держави), хоча багато даних обліку і звітності залишалися і залишаються затребуваними і для внутрішнього управління.

Потреба в обліковій інформації для свого підприємства не тільки збереглася, а й посилилася в зв'язку з ускладненням виробничої діяльності, господарського життя і фінансових відносин організацій. 3'явився ринок цінних паперів, більш різноманітними стали фінансові та банківські розрахунки і операції, виробництво від ручного індивідуального ремесла перейшло до стандартизованого, потоковим методам, різко підвищилася роль техніки і технології у виготовленні продукції та наданні послуг, в рази зросла їх номенклатура. Частково цю проблему формування інформації, необхідної для внутрішнього управління, намагалися вирішити за рахунок розробки і експлуатації різних варіантів диспетчерського, оперативнотехнічного, щоденного обліку роботи підприємства, проте всі зазначені системи засновані на кількісних показниках діяльності і не включають вартісні, на яких будується управління економікою господарюючого суб'єкта. Існували й спроби використання для управління підприємством даних щоденного обліку собівартості продукції, робіт, послуг, але і вони виявилися невдалими, головним чином тому, що отриману інформацію не можна було визнати бухгалтерською [5]. Бухгалтерія відповідає за достовірність своєї звітності тільки після повного завершення облікових процедур, включаючи закриття рахунків, визначення оборотів і сальдо по кожному 3 них. Таке може статися не раніше закінчення облікового періоду, тобто як мінімум не раніше місяця. Аля управління потрібна інформація до моменту прийняття рішення, тобто в будь-який день місяця або чим швидше, тим краще. Ао того ж дані бухгалтерського обліку і звітності характеризують минуле і сьогодення, а для управління, крім того, потрібна інформація про можливе майбутнє. Неможливість існуючої системи бухгалтерського обліку передбачити, що чекає підприємство найближчим і більш віддалений час, "заглянути" після звітного року вперед, що для будь-якого управління обов'язково, призвело до необхідності особливого виду обліку управлінського і найбільш розвиненою форми використання його даних - контролінгу. 
Розмежування двох видів обліку відбулося головним чином в останні двадцять років. У результаті облікова інформація стала виконувати в багатьох організаціях іншу, додаткову функцію, а бухгалтер з бухгалтерського обліку отримав якісно новий статус. Управлінська облікова інформація стала використовуватися в поєднанні з інформацією, раніше не відображеною в бухгалтерському обліку, така, наприклад, як показники ринкової кон'юнктури, задоволеність споживача, внутрішня ефективність виробничих витрат і мотивація працівників. Як наслідок, фахівці з бухгалтерського обліку все більше залучаються в такі сфери господарської діяльності підприємства, як маркетинг, розробка, виготовлення і збут продуктів, управління матеріальними і трудовими ресурсами.

Одних традиційних облікових методів виявляється вже недостатньо; функції бухгалтера з бухгалтерського обліку складаються не просто в підготовці періодичних звітів про витрати і результати діяльності для менеджерів різних рівнів управління, але в забезпеченні відповідної фінансової та нефінансової інформацією керівників, які відповідають за прийняття рішень з цілого ряду професійних питань, таких як маркетинг, фінансова та організаційна діяльність, цінова політика, стратегічне планування та контроль [11].

Всі ці аспекти в тій чи іншій мірі повинні бути об'єктом теорії бухгалтерського обліку. Початок теорії формування і практичного використання системних методів обліку для внутрішнього управління економічними показниками діяльності підприємств було покладено розробкою, апробацією і застосуванням ідей вдосконалення нормативного обліку і контролю витрат підприємств. Бухгалтерський облік забезпечує можливість вибору оптимального для заданих умов варіанта витрат, прогнозування витрат і фінансових результатів діяльності, контролю за ними шляхом виявлення відхилень від заздалегідь встановлених величин. За порівняно менших витратах на ведення обліку менеджери отримували інформацію для оперативного, цілеспрямованого внутрішньофірмового управління за усіма основними показниками діяльності підприємства. Крім звичайного, властивого бухгалтерському обліку призначенням, управлінський облік став частиною не тільки виробничих, а й маркетингових інформаційних систем, використовуваних для ціноутворення і ведення переговорів з клієнтами та профспілками, підведення підсумків руху ка- піталу і поточних операцій, планування податкових відрахувань [13].

Бухгалтерський облік у нашій країні сьогодні набуває все більшого визнання. Висловлюється навіть думка про те, що підприємствам сьогодні потрібно зосередити увагу в основному на організації та ведення обліку для внутрішнього управління, а бухгалтерський облік обмежити необхідністю дотримання вимог податкового законодавства, тобто перетворити його в податковий облік. 3 цим погодитися не можна, оскільки у бухгалтерського обліку та звітності призначення інше, ніж у податкового, і необхідність в ньому обумовлена принципами, які наша країна взяла на себе зобов'язання дотримуватися. Потрібна і відособлена теорія такого обліку, його наукова база. Певною мірою зусиллями зарубіжних і вітчизняних вчених основа її була створена, але як будь-яка творча наука зазначена теорія потребує постійного розвитку і вдосконалення. Наукові дослідження з визначення формуються в пошуку нового, ще не відомого, такого що просуває діючу практику вперед. Цілком і повністю це відноситься і до бухгалтерського обліку, в теорії якого ще багато "білих плям" і різних варіантів вирішення методологічних та організаційних проблем. Розглянемо окремі з них в певній сукупності і послідовності, особливо відзначивши, що в бухгалтерському обліку істотно більше можливостей для творчого підходу, ніж в обліку фінансовому, який обмежений рамками нормативно-професійної та державної регламентації.

Сутність бухгалтерського обліку та сфера його застосування. Сьогодні існує багато трактувань змісту обліку для внутрішнього управління виробничо-господарською діяльністю організації, сфери його застосування, об'єктів і суб'єктів обліку. Одні дослідники бачать в бухгалтерському обліку засоби і методи отримання інформації, яка потрібна для прийняття управлінських рішень керівництвом, інші вважають його набором облікових регістрів для менеджерів своєї організації, де не допустимі передбачені обліковою політикою деякі відхилення від абсолютної істини, треті розглядають бухгалтерський облік як сукупність додаткових методів, що дозволяють оптимізувати здійснення внутрішньогосподарських розрахунків, формування трансфертних цін і т.А. Існують думки, що бухгалтерський облік - це добре відомий раніше оперативно-технічний облік, доданий вартісними показниками, а також, що він являє собою дещо розлогий розділ 
обліку витрат і калькулювання собівартості продукції, робіт, послуг підприємства [4; 7].

Зараз на практиці і в більшості підручників і навчальних посібників бухгалтерський облік в основному розглядається як система обчислення і контролю за витратами і результатами виробничо-збутової, торгової і посередницької діяльності комерційних організацій $[3 ; 5 ; 8]$. Таке визначення обліку в принципі правильне, оскільки будь-яке управлінське рішення для своєї реалізації вимагає відповідних витрат, від здійснення яких очікується певний результат. Але це в рівній мірі відноситься і до інших видів бізнесу господарюючого суб'єкта. На думку автора, крім виробництва та продажів, в сферу обліку для менеджерів слід включити і інноваційну, фінансову, маркетингову та іншу комерційну діяльність, незалежно від того, чи здійснюється вона як основний або супутній вид бізнесу організації.

Можливість включення в сферу бухгалтерського обліку всіх видів підприємницької і некомерційної діяльності обумовлена не тільки тим, що всі вони так чи інакше пов'язані з витратами, які вимагають контролю і управління. Багато в чому спільними є способи бюджетування, нормування витрат, виявлення відхилень від норм, методи їх факторного аналізу та оцінки раціональності. Стосовно до витрат, незалежно від їх галузевої та функціональної належності, тут застосовні різні варіанти властиві тільки бухгалтерському обліку методики.

У сукупності система бухгалтерського обліку повинна включати формування інформації:

- для менеджменту різного рівня відповідальності за прийняті рішення по управлінню;

- 3 метою контролю виробничо-збутової, інноваційної та фінансової діяльності;

- для ціноутворення на продукцію і послуги, здійснення цінової і податкової політики;

- для аналізу руху основного і оборотного капіталів і поточних операційних витрат;

- для ведення переговорів 3 клієнтами, профспілковими організаціями, представниками муніципальної влади.

Будь-яке управління пов'язано 3 необхідністю контролю за виконанням управлінських рішень. У бухгалтерському обліку контрольні функції проявляють себе дещо по-іншому. Тут присутні не тільки спостереження вищого керівництва за роботою підрозділів або осіб, але передусім самоконтроль виконання службових обов'язків менеджера, перевірка того, як він сам сприяє досягненню цілей організації і наскільки ефективно і оперативно здійснює ко- ригувальні дії, якщо цього не відбувається. Контроль включає встановлення стандартів діяльності, виявлення відхилень і визначення способів їх усунення. Крім звичайного для обліку контролю за витратами, бухгалтерський облік повинен здійснювати контроль і за операційними витратами.

Операційні витрати в бухгалтерському обліку - це витрати за операціями виготовлення і збуту продукції і послуг, а також витрати, пов'язані з укладенням угод: з вибором партнерів, 3 підписанням договорів і угод, із здійсненням контролю за їх виконанням, адаптацією до змін в діяльності.

У кінцевому підсумку ефективне управління $€$ не що інше, як правильний вибір цілей управління і їх досягнення з мінімальними витратами.

Головним у методиці бухгалтерського обліку завжди була орієнтація на визначення оптимальних (з кількох альтернативних) показників виробничо-фінансової діяльності на найближче і віддалене майбутнє, а також виявлення відхилень від заздалегідь заданих параметрів. Це стосується запасів товарно-матеріальних цінностей, витрат за видами, місцями формування і центрам відповідальності, надходжень і витрат грошових коштів, результатів основної, інноваційної та іншої комерційної діяльності. В результаті коригуючий вплив на керований об'єкт (запаси, витрати, прибуток і ін.) здійснюється на основі інформації про відхилення від заздалегідь заданих параметрів стану або поведінки об'єкта управління. Аані про відхилення використовуються для виявлення причин перевитрат, подорожчань, непродуктивних витрат, зниження рівня продажів, виручки і прибутку. Результативність та ефективність рішень з управління виробничо-господарською діяльністю підприємства при цьому істотно підвищується.

\section{ВИсновКИ І пРопозиції}

Аля подальшого розвитку теорії та практики бухгалтерського обліку необхідні більш досконалі методи стандартизації, нормалізації, нормування керованих параметрів і відхилень від їх заданої величини, в тому числі з використанням економіко-математичних методів і ITтехнологій. Навіть у частині витрат на виробництво і продаж продукції, роботи, послуги, закупівлю і реалізацію товарів в торгівлі потрібні більш економічно і математично обгрунтовані методики прогнозування, планування, обліку і регулювання спочатку заданих витрат за різних умов і обставин їх формування. 
Водночас слід враховувати рівень завантаження виробничих потужностей і можливість використання інших можливостей підприємства, що дозволить оцінювати ефективність вкладеного в бізнес капіталу. Капітал завжди був і залишається обмеженим і дефіцитним ресурсом, крім того він має тенденцію до подорожчання. Будь-яка незлагодженість у завантаженні устаткування та інших основних засобів, а також надлишки запасів матеріальних ресурсів і збільшена чисельність виробничого і обслуговуючого персоналу ведуть до невиправданих витрат і знижують конкурентоспроможність підприємства.

Таким чином, в якості основних тенденцій розвитку бухгалтерського обліку та звітності слід виділити:

1) створення досконалішої законодавчӧ̈ бази для застосування МСФЗ;

2) націленість економічних суб'єктів на формування інтегрованих обліково-аналітичних систем із застосуванням в їх рамках різних видів обліку, а також фінансової та нефінансової звітності;

3) зміна системи регулювання бухгалтерського обліку та звітності і формування змішаної моделі регулювання;

4) вдосконалення аудиторської діяльності на основі їі стандартизації, посилення вимог до підготовки аудиторів, а також введення вимоги про організацію в кожному економічному суб'єкті системи внутрішнього контролю;

5) реформування системи підготовки та перепідготовки бухгалтерів та аудиторів.

Мітература:

1. Закон України "Про бухгалтерський облік та фінансову звітність в Україні" від 16.07.1999 № 996-XIV. - Відомості Верховної Ради України (ВВР). 1999. № 40. - Режим доступу: http://zakon0.rada.gov.ua/laws/show/ 996-14

2. Закон України "Про внесення змін до Закону України "Про бухгалтерський облік та фінансову звітність в Україні" від 05.10.2017 № 2164-VIII. - Режим доступу: http:// zakon1.rada.gov.ua/laws/show/2164-19

3. Cescon F., Costantini A., and Grassetti L. Strategic choices and strategic management accounting in large manufacturing firms. Journal of Management and Governance. 2018. 23 (3), $605-636$.

4. Kamal Sh. Historical Evolution of Management Accounting, The Cost and Management. 2015.43 (4). 12-19.
5. Pavlatos O., and Kostakis X. The impact of top management team characteristics and historical financial performance on strategic management accounting. Journal of Accounting and Organizational Change. 2018. 14 (4). 455-472.

6. Petera P., and Soljakov L. Use of strategic management accounting techniques by companies in the Czech Republic. Economic researchekonomska istrazivanja. 2019. 33 (1), 46-67.

7. Ratynskyi V., Shostakivska N., and Pavlykivska O. Problems evolutionary process of production, its management and accounting. Economics, Management, Law: socio-economic aspects of development": Collection of scientific articles. Edizioni Magi, Roma, Italia. 2016, P. 112-117

8. Semenyshena N.V. Accounting and financial reporting: problems of harmonization with IFRS. Visnyk Sumskoho natsionalnoho ahrarnoho universytetu. Seriia: Finansy i kredyt. 2013. 2. $138-144$.

9. Valipour H., and Kaviani Fard H. The importance of the field of industry in the type of management accounting procedures. Journal of Accounting Research. 2017.7 (3), 81-95.

10. Vasquez A.U. and Naranjo-Gil D. Management Accounting Systems, Top Management Teams, and Sustainable Knowledge Acquisition: Effects on Performance. Sustainability. 2020. 12 (5). $1-14$.

11. Богатая И.Н., Евстафьева Е.М. Исследование современных тенденций развития бухгалтерского учета и отчетности, Международный бухгалтерский учет. 2013. № 25. С. 2-17.

12. Ивашкевич В.Б. Проблемы теории управленческого учета и контроллинга // Международный бухгалтерский учет. 2015. № 7 (349). С. $2-14$.

13. Канцедал Н.А. Бухгалтерський облік цифрової епохи: розширення термінологічних кордонів. Accounting and Finance. 2019. № 1 (83). С. $29-34$.

14. Краус Н.M., Голобородько О.П., Краус К.М. Цифрова економіка: тренди та перспективи авангардного характеру розвитку. Ефективна економіка. 2018. № 1.

15. Семенишена Наталія. Бухгалтерський облік як інститут: огляд досліджень. Інститут бухгалтерського обліку, контроль та аналіз в умовах глобалізації. 2019. Вип. 3-4. С. 7-18.

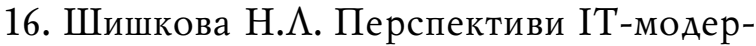
нізації бухгалтерського обліку: актуалізація теорії і практики. Економіка підприємства. Економічний вісник. 2019. № 3. С. 149-159.

17. Яструбський М.Я. Теорія і практика бухгалтерського обліку в період цифрової економіки. Сучасні питання економіки і права. 2020. 
Збірник наукових праць. Вип. 1 (11) Серія: економічні науки. С. 187-203.

\section{References:}

1. Verkhovna Rada of Ukraine (1999), The Law of Ukraine "On Accounting and Financial Reporting in Ukraine", available at: http://zakon0.rada.gov.ua/laws/show/996-14 (Accessed 23 March 2021).

2. Verkhovna Rada of Ukraine (2017), The Law of Ukraine "On Amendments to the Law of Ukraine "On Accounting and Financial Reporting in Ukraine" to Improve Certain Provisions", available at: http://zakon1.rada.gov.ua/laws/ show/2164-19 (Accessed 23 March 2021).

3. Cescon, F. Costantini, A. and Grassetti, L. (2018), "Strategic choices and strategic management accounting in large manufacturing firms", Journal of Management and Governance, , vol. 23 (3), pp. 605-636.

4. Kamal, Sh. (2015), "Historical Evolution of Management Accounting", The Cost and Management, vol. 43 (4), pp. 12-19.

5. Pavlatos, O. and Kostakis, X. (2018), "The impact of top management team characteristics and historical financial performance on strategic management accounting", Journal of Accounting and Organizational Change, vol. 14 (4), pp. 455-472.

6. Petera, P. and Soljakov, L. (2019), "Use of strategic management accounting techniques by companies in the Czech Republic", Economic researchekonomska istrazivanja, vol. 33 (1), pp. 46-67.

7. Ratynskyi, V. Shostakivska, N. and Pavlykivska, O. (2016), "Problems evolutionary process of production, its management and accounting", Economics, Management, Law: socio-economic aspects of development": Collection of scientific articles, Edizioni Magi, Roma, Italia, pp. 112-117.

8. Semenyshena, N.V. (2013), "Accounting and financial reporting: problems of harmonization with IFRS", Visnyk Sumskoho natsionalnoho ahrarnoho universytetu. Seriia: Finansy i kredyt, vol. 2, pp. 138-144.

9. Valipour, H. and Kaviani Fard, H. (2017), "The importance of the field of industry in the type of management accounting procedures", Journal of Accounting Research, vol. 7 (3), pp. 81-95.

10. Vasquez, A.U. and Naranjo-Gil, D. (2020), "Management Accounting Systems, Top Management Teams, and Sustainable Knowledge Acquisition: Effects on Performance", Sustainability, vol. 12 (5), pp. 1-14.

11. Bohataia Y.N. and Evstaf'eva E.M. (2013), "Research of modern trends in the development of accounting and reporting", Mezhdunarodnyj bukhhalterskyj uchet, vol. 25, pp. 2-17.
12. Yvashkevych, V.B. (2015), "Problems of the theory of management accounting and controlling", Mezhdunarodnyj bukhhalterskyj uchet, vol. 7 (349), pp. 2-14.

13. Kantsedal, N.A. (2019), "Accounting of the digital age: expanding terminological boundaries", Accounting and Finance, vol. 1 (83), pp. 29-34.

14. Kraus, N. M., Goloborodko, O. P. and Kraus, K. M. (2018), "Digital economy: trends and perspectives of the abangard change of development", Efektyvna ekonomika, [Online], vol. 1, available at: http://www.economy.nayka.com.ua/ ?op $=1 \& \mathrm{z}=6047$ (Accessed 23 March 2021).

15. Semenyshena, N. (2019), "Accounting as an institution: a review of research", Instytut bukhhalters'koho obliku, kontrol' ta analiz v umovakh hlobalizatsii, vol. 3-4. pp. 7-18.

16. Shyshkova, N.L. (2019), "Prospects for ITmodernization of accounting: updating theory and practice", Ekonomika pidpryiemstva. Ekonomichnyj visnyk, vol. 3, pp. 149-159.

17. Yastrubs'kyj, M.Ya. (2020), "Theory and practice of accounting in the digital economy", Suchasni pytannia ekonomiky i prava. Zbirnyk naukovykh prats'. Seriia: ekonomichni nauky, vol. 1 (11), pp. 187-203.

Стаття надійшла до редакиї̈ 10.04.2021 p.

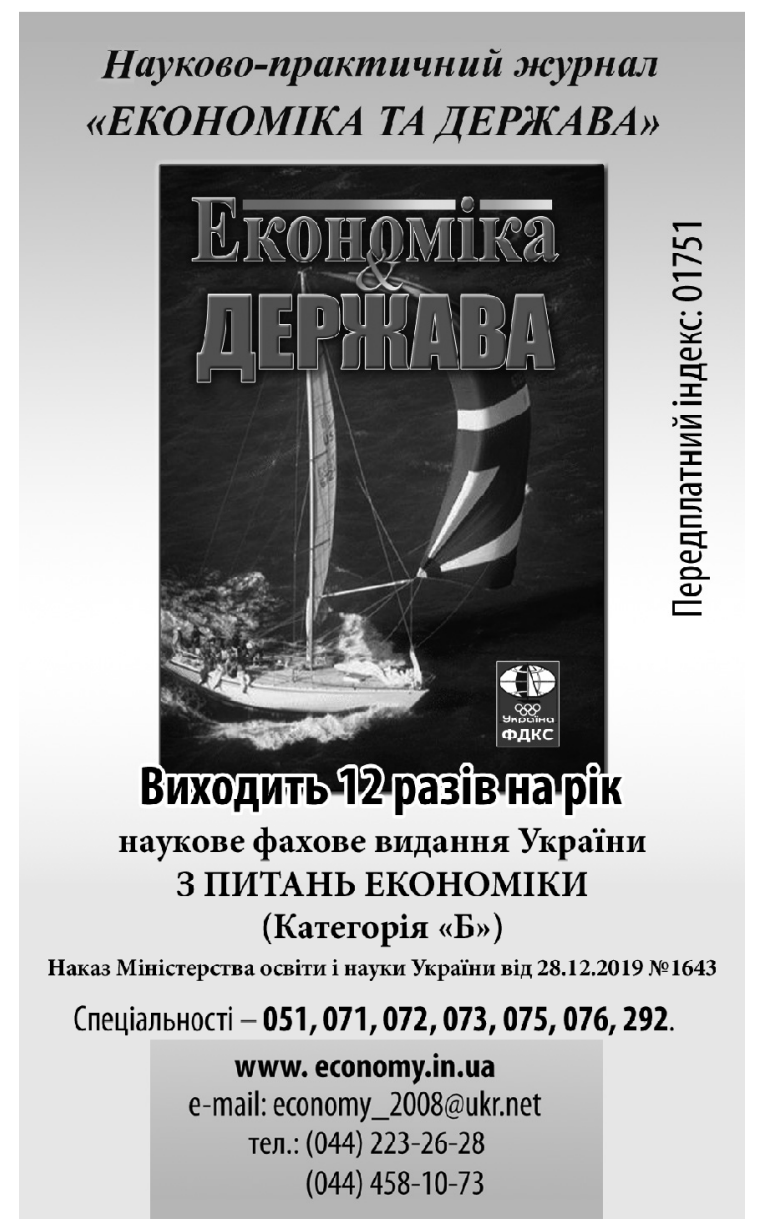




\title{
УAK 336.743
}

I. М. Макарчук,

к. е. н., Аоцент, доцент кафедри фінансів, обліку і оподаткування, АВНЗ "Переяслав-

Хмельницький державний педагогічний університет імені Григорія Сковороди", м. Переяслав ORCID ID: 0000-0001-8434-5660

O. В. Перчук,

к. е. н., Аоцент, доцент кафеАри фінансів, обліку і оподаткування, АВНЗ "Переяслав-

Хмельницький Аержавний пеАагогічний університет імені Григорія Сковороди", м. Переяслав ORCID ID: 0000-0003-3549-5544

М. М. Яременко, к. е. н., Аоцент, Аоцент кафеАри фінансів, обліку і оподаткування, АВНЗ "Переяслав-

Хмельницький Аержавний педагогічний університет імені Григорія Сковороди", м. Переяслав ORCID ID: 0000-0003-3127-5181

A. B. Стратан, аспірант 1-го року навчання кафедри фінансів, обліку і оподаткування, спеціальності 072 Фінанси, банківська справа та оподаткування, АВНЗ "Переяслав-Хмельницький державний педагогічний університет імені Григорія Сковороди"

ORCID ID: 0000-0001-7053-0208

DOI: $10.32702 / 2306-6792.2021 .7-8.85$

\section{ОСОБАИВОСТІ ФУНКЦІОНУВАННЯ СВІТОВОГО РИНКУ КРИПТОВААЮТИ В УМОВАХ ТРАНСФОРМАЦІЙНИХ ЗМІН ГАОБААЬНОГО ЕКОНОМІЧНОГО СЕРЕАОВИЩА}

\author{
I. Makarchuk, \\ $\mathrm{PhD}$ in Economics, Associate Professor, SHEE "Pereyaslav-Khmelnytskiy SPU \\ after Grygoriy Skovoroda", Pereyaslav-Khmelnytskiy \\ O. Perchuk, \\ $\mathrm{PhD}$ in Economics, Associate Professor, SHEE "Pereyaslav-Khmelnytskiy SPU \\ after Grygoriy Skovoroda", Pereyaslav-Khmelnytskiy \\ L. Yaremenko, \\ $\mathrm{PhD}$ in Economics, Associate Professor, SHEE "Pereyaslav-Khmelnytskiy SPU \\ after Grygoriy Skovoroda", Pereyaslav-Khmelnytskiy \\ A. Stratan, \\ Postgraduate student, SHEE "Pereyaslav-Khmelnytskiy SPU \\ after Grygoriy Skovoroda", Pereyaslav-Khmelnytskiy
}

FEATURES OF THE FUNCTIONING OF THE WORLD CRYPTOCURRENCY MARKET

IN THE CONTEXT OF TRANSFORMATIONAL CHANGES

IN THE GLOBAL ECONOMIC ENVIRONMENT

У статті розкрито економічну природу криптовалюти як інформаційно-технологічної інновації. На основі технічних, технологічних та організаційних аспектів використання криптовалют Аано порівняльну характеристику електронних грошей і криптовалюти. Визначено, що криптовалюта - це швидка і надійна система платежів та грошових переказів, заснована на новітніх інноваційних технологіях, непідконтрольна жодному уряду, не залежна від банківських систем та захищена криптографією. Проведено аналіз ринків і видів криптовалюти, що Аало змогу сформувати рейтинг криптовалют по рівню капіталізації. Показано динаміку зростання капіталізації ринку криптовалют із домінуючою часткою Біткойна. Визначено сильні сторони Біткойна, які зробили цю криптовалюту зручним міжнародним платіжним засобом з високим інвестиційним потенціалом. Аосліджено недоліки обігу криптовалюти як Аля 
пересічних споживачів, так і держави загалом. Аоведено, що Аля ефективного функціонування криптовалюти необхідна їх інституалізація, яка зАійснюється завдяки формальному і неформальному встановленню правил щодо функціонування криптовалюти. Обгрунтовано три позиції інституційного забезпечення по відношенню країн до функціонування ринку криптовалюти: лояльна, категорична та позиція очікування. Розроблений організаційно-економічний механізм формування ринку криптовалюти, в основу якого закладено функції, методи та інструменти управління, а також запропоновані напрями реалізації політики в сфері функціонування ринку криптовалюти Аля країн 3 позицією очікування.

The article reveals the economic essence of cryptocurrency as an information and technological innovation. Having considered technical, technological, and organizational aspects of using cryptocurrencies, the authors carried out the comparison of electronic money and cryptocurrency. The authors have determined that cryptocurrency is a universal global means of payment, exchange, and investing, which exists in the form of a highly protected software code and is characterized by a free market exchange rate. The done analysis of markets and types of cryptocurrencies has enabled to form a ranking of cryptocurrencies by level of capitalization. The article describes the dynamics of the growth of cryptocurrency market capitalization and the domination of a Bitcoin's market share. The authors have ascertained strengths of Bitcoin, which had allowed this cryptocurrency to become a useful international means of payment with the high investment potential. The article examines weaknesses of the exchange of cryptocurrency both ordinary consumers and governments. The authors have proven that institutionalization ensured by the formal and informal establishment of rules for functioning of cryptocurrency is necessary for effective functioning of cryptocurrency. The authors have substantiated three positions of institutional support describing the attitude of countries to functioning of a cryptocurrency market: a loyal position, categorical position, and position of anticipation. The authors have developed an organizational and economic mechanism for forming a cryptocurrency market based on functions, methods, and tools of management and suggested directions for undertaking a policy in the sphere of functioning of a cryptocurrency market for countries with the position of anticipation. The process of virtualization of modern society is inevitable. Countries with the position of anticipation should support the course on innovation by solving a range of regulatory, technical and information issues on the development of the cryptocurrency market, based on leading international experience. The primary tasks should be: granting the legal status of cryptocurrency and developing rules for its circulation, introduction of technological innovations with the participation of the state, large corporations and venture funds, creation of an open ecosystem for interaction of all participants, as well as wide information support at all levels.

Ключові слова: капіталізачія, електронні гроші, віртуальна валюта, ІТ-технологія, Біткойн, майнінг, криптовалюта.

Key words: capitalization, electronic money, virtual currency, information technology, Bitcoin, mining, cryptocurrency.

\section{ПОСТАНОВКА ПРОБЛЕМИ}

Стрімкий розвиток інформаційних технологій трансформує сучасну економічну систему. За різними підрахунками обсяг інтернет-торгівлі у 2020 році перевищив позначку в 2,8 трлн дол. США. Водночас, якщо інтернетторгівля - це лише зміна способу продаж, то новації останніх десятиліть у сфері IT-технологій, а саме криптовалюти кидають виклик існуючій грошовій системі та базовим її засадам. Так, майже дев'ять років назад, одночасно 3 першими транзакціями Bitcoin (Біткоїн) "першою децентралізованою цифровою валютою" [1], в лексикон економістів і науковців увійшло поняття криптовалюти. Починаючи 3 2009 року криптовалюта охарактеризувала себе як новий і перспективний інноваційний фінансовий інструмент інформаційної економіки, знайшовши своє визнання серед інвесторів та підприємців у всьому світі та маючи особливе значення для фінансової системи загалом, та для банківських систем багатьох країн світу - зокрема. Криптовалюта як інформаційно-технологічна інновація в розвитку су- часних платіжних систем за досить короткий термін набула популярності, тим самим завоювавши провідні позиції на глобальному фінансовому ринку та стала частиною повсякденного побуту кожного середньостатистичного жителя планети.

\section{АНАЛІЗ ОСТАННІХ ДОСЛІДЖЕНЬ І ПУБЛІКАЦІЙ}

На теоретичному рівні відсутній єдиний підхід щодо фінансової та правової природи криптовалюти як інформаційно-технологічної інновації. Окремі питання регулювання операцій з криптовалютою досліджували такі вітчизняні та закордонні вчені: М. Андручович, М. Гребенюк, А. Квітка, Р. Аук'янчук, М. $\Lambda$ ихачова, А. Полчанова, М. Роесчлін, І. Аоронін $\mathrm{i}$ iH.

Найвідомішими іноземними авторами у цій cфepi є: R. Bohme, N. Christin, B. Edelman, T. Moore, J. Bonneau, A. Miller, Jeremy Clark, A. Narayanan, J. Kroll, E. Felten, R. Schultz, S. Vassiliadis, P. Papadopoulos, M. Rangoussi, T. Konieczny, J. Gralewski, O. Николайчук. 
Методологічна основа дослідження базується на використанні сучасних положень економічної теорії, фінансів, валютної системи та інтернет матеріалів, які є у відкритому доступі. У статті використані загальнонаукові методи пізнання явищ об'єктивної дійсності, інші загальнонаукові та спеціальні методи, а саме: формально-логічний (під час визначення економічної природи криптовалюти як інноваційного платіжного засобу), історико-правовий (під час визначення генезису категорії "криптовалюта"), системного аналізу (під час оцінки перспектив використання криптовалюти Біткойн у фінансових відносинах), порівняльний (загальному аналізі ринку криптовалют), статистичний (під час побудови рейтингу криптовалют) та метод логічного узагальнення (під час розробки організаційно-економічного механізму формування ринку криптовалюти).

\section{ВИДІЛЕННЯ НЕ ВИРІШЕНИХ РАНІШЕ ЧАСТИН ЗАГАЛЬНОЇ ПРОБЛЕМИ}

Аналіз робіт вказаних вчених дозволив виявити недосконалість наукових досліджень щодо необхідності використання діквідного потенціалу криптовалюти для розвитку національних економік. Ці питання є недостатньо вивченими та потребують подальшого глибокого дослідження, адже більшість розвинутих країн адаптують своє законодавство для регулювання віртуальної валюти, що дозволить поетапно пристосувати інновації фінансового ринку - криптовалюту до сучасних реалій.

\section{META CTATTI}

Метою статті є дослідження тенденції розвитку криптовалюти як фінансово-технологічної інновації у світовій фінансовій системі.

\section{ВИКЛАДЕННЯ ОСНОВНОГО МАТЕРІАЛУ}

Стрімкий розвиток інформаційних технологій та поширення глобалізаційних процесів сприяли появі нових різновидів цифрової валюти, головними перевагами яких є децентралізованість і повна свобода здійснення транзакцій.

Криптовалюта це дешевий, зручний і технологічний спосіб для здійснення розрахункових операцій у всьому світі, та перспективна форма здійснення інвестицій. Згідно зі статистичними даними CoinMarketCap [1], капіталізація ринку криптовалют станом на 21.03.2021 р. становила близько 1597601784622 дол. доларів США. Враховуючи сучасний розвиток криптовалюти у світовому маштабі, у центрі уваги $€$ криптовалюта Біткойн та технологія Blockchain.
Біткойн на сьогодні є й найдорожчою з-поміж існуючої криптовалюти. 3 кожним роком в усьому світі зацікавленість економічно активної частини населення фінансовими інноваціями у сфері інформаційної економіки зростає.

"Першою реалізацією концепції криптовалюти став Біткойн, принцип роботи якого було описано ще у 2008 році. Його засновником прийнято вважати Сатоші Накамото (англ. Satoshi Nakamoto), який в кінці жовтня 2008 року описав технічні аспекти функціонування майбутньої криптовалюти, а в січні 2009 року виклав в загальний доступ першу версію коду цієї електронної валюти. Варто зауважити, що появі Біткойна та інших криптовалют передувала велика кількість глобальних досліджень" [6].

Сьогодні немає єдиної думки щодо визначення терміна "криптовалюта". Аеякі науковці відносять криптовалюту до "віртуальної валюти" та називають інноваційною мережею платежів і новим видом грошей, інші заперечують "причетність" криптовалюти до грошей та називають "цифровим активом".

Узагальнюючи різні дефініції, можна позиціонувати криптовалюту як універсальний світовий засіб платежу, обігу та інвестування, що існує у вигляді програмного коду з високим ступенем захищеності і характеризується вільним ринковим курсом.

Використовуючи традиційні кошти, взаємозв'язок відбувається лише між покупцями та продавцями за принципом спочатку гроші потім товар, це і забезпечується миттєвістю операцій за умови однакової локалізації контрагентів, але робить не можливою їх реалізацію у випадку не однакової локалізації контрагентів. Використання цифрової валюти стало вирішенням проблеми, яку описати можна як рядок бітів в найзагальнішому вигляді. За такої системи платежів обов'язковим $є$ наявний посередник, тобто електронна платіжна система. 3 метою недопущення повторності набору бітів основним завданням платіжної системи є централізоване управління фінансовими операціями, тобто - бухгалтерський контроль. На сучасному етапі $є$ велика кількість подібних платіжних систем, що підвищує ризик шахрайства та небезпеки даних. Криптовалюта не передбачає обов'язкового залучення третьої особи під час здійснення операцій з грошима.

Криптовалютні системи прагнуть забезпечити дотримання декількох принципів: консенсусу, безпеки та унікальності, правильної перевірки трансакцій. Базою їх реалізації на практиці вважається процес "видобутку". Особи, що 
Таблиця 1. Порівняльна характеристика електронних грошей і криптовалюти

\begin{tabular}{|l|l|l|}
\hline Характеристики & \multicolumn{1}{|c|}{ Електронні гроші } & \multicolumn{1}{|c|}{ Криптовалюта } \\
\hline Емітент & Центральні банки & Майнери \\
\hline Форма & Цифрова & Цифрова \\
\hline Зміст & Зобов'язання емітента & $\begin{array}{l}\text { Незалежний } \\
\text { нематеріальний актив }\end{array}$ \\
\hline Спосіб внесення & $\begin{array}{l}\text { Внесення на рахунок у } \\
\text { фізичному втіленні }\end{array}$ & $\begin{array}{l}\text { Генерація в мережі } \\
\text { математичними } \\
\text { методами }\end{array}$ \\
\hline Ризики & $\begin{array}{l}\text { Контролюються } \\
\text { інституціями }\end{array}$ & Не контрольовані \\
\hline $\begin{array}{l}\text { Швидкість } \\
\text { транзакцій }\end{array}$ & Менша & Максимальна \\
\hline Транзакційні & Потрати
\end{tabular}

Ажерело: розроблено авторами особисто.

його забезпечують, здійснюють дорогі програмно-обчислювальні операції на конкурентних засадах: переможець має право створити нову історію в мережі, оновивши "blockchain". У найбільш простому вираженні даний термін охоплює сукупність усіх минулих трансакцій, а точніше - ідентифікаційні облікові відомості про них. Під дефініцією "block" розуміють поточні трансакції, що базуються на попиті та пропозиції на криптовалюту. Сукупність таких "блоків" і формує історію "blockchain". Тобто очевидно, що за таких умов повернення до минулої трансакції є практично неможливим [16].

Технологію блокчейн у світі в перспективі можна активно використовувати не тільки для IT-технологій та кібербезпеки, а й для зберігання даних у торгівлі нерухомістю та реєстрації майна, в кадастровому обліку, державному управлінні, банківській сфері, освіті, медицині, торгівлі, страхуванні, судовому діловодстві тощо. Оскільки технологія блокчейн це самодостатня, безпечна, децентралізована, надійна та дешева.

"Технічні, технологічні та організаційні аспекти використання криптовалют, вказують на те, що вони майже тотожні з електроним видом грошей безготівкової форми їх обороту. Однак, хибним $€$ повне ототожнення криптовалюти з безготівковими грошима в цілому, i ïх окремого виду - електронними грошима. Схожість проявляється у тому, що криптовалюти як електронні гроші $є$ неперсоніфікова- ним платіжним інструментом (тобто не потребують ідентифікації власника) та обертаються поза межами банківської системи в електронному вигляді. Якщо емітенти електронних грошей мають тісно взаємодіяти із банками для забезпечення вільного обміну електронних грошей на традиційні і навпаки, то криптовалюти не є "банківськими грішми", вони не враховуються при розрахунку монетарних агрегатів та не можуть бути використані для здійснення банківських послуг (прийому депозитів та видачі кредитів)" [7]. Порівняльна характеристика електронних грошей і криптовалюти відображена в таблиці 1.

За словами доктора Гаррика Хайлмена, криптовалюти стають все більш важливою частиною суспільства та роботи техніки у всьому світі. Так, судячи 3 дослідження, кількість людей, які використовують криптовалюту, зросла і наближається до населення невеликої країни - від 2,9 до 5,1 мільйона чоловік. Більшість є жителями Північної Америки і Європи.

Найбільш поширеною світовою криптовалютою сьогодення $є$ Біткойн, який продовжує свій розвиток, кількість користувачів цієї системи у світі невпинно зростає. Популярність Біткойн відповідно сприяла створенню і інших криптовалют, що розвиваються поряд 3 Біткойн, хоча їхні можливості і популярність поки що набагато менші. У деяких країнах 3 Біткойн почали боротися, пояснюючи це турботою про людей, застереженням їх від вкладення грошей в "грошові сурогати" і можливої ї втрати, якщо настав би крах Біткойн. Однак насправді така боротьба, найімовірніше, викликана бажанням сконцентрувати функції грошової емісії, а значить - і влади, в руках держави і не допустити утворення альтернативних джерел емісії платіжних засобів, оскільки вони не піддаються ніякому державному регулюванню [8].

На думку аналітиків, ринок криптовалюти є вигідним для великих компаній, адже володіння значним капіталом у різних країнах світу, який не прив'язаний до місцевих валют, зумовлює зацікавленість ринком віртуальних грошей [9].

Протягом 2019-2020 рр. ринок генерації криптовалют був поділений так: Китай - 60,1\%, США та Канада - 16,05 \%, Грузія - 6,1\%, Европа - 5,2\%, Ісландія - 4,1\%, Індія - 3,1\%, Росія - 1,9\%, Австралія - 1,8\%, Південна Америка - 1,9\%. Цифровий обмін криптовалютами здійснюється на таких світових біржах, 
як "Bitfinex", "Poloniex", "Kraken", "Shapeshift", "Changelly", CHBTC, "Bitsquare", "Bittrex", "BitMEX", BTER, "Yobit", "CoinExchange", "LiteBit", "Btc Markets" тощо [10].

Загальна кількість криптовалют станом на 21 березя 2021 року налічує 1228 назв. Водночас п'ятірка лідерів ринку показує приріст капіталізації щонайменше 253 млн дол. США за добу (табл. 2).

Аналізуючи динаміку цін криптовалют в останні роки можна сказати, у першу чергу, що це класична "піраміда". Хоча у заяві уряду Великої Британії: в документі під назвою "Цифрові валюти: відповідь на запит інформації" вказано, що використання цифрових валют має мінімальні ризики для фінансової стабільності та кредитно-грошової системи держави [16].

Сучасний розвиток інфраструктури безготівкових платежів та IT-технологій призводить до суттєвої зміни механізму грошової емісії. Тому поступово з'являються ознаки офіційного визнання криптовалют фінансовим істеблішментом. Найбільші інвестиційні банки ("Goldman Sachs", "Merrill Lynch", "Bank of America") випускають огляди перспектив різних криптовалют, що свідчить про практичне їх "вписання" у традиційну фінансову індустрію. Шість великих міжнародних банків ("Barclays", "Credit Suisse", "Canadian Imperial Bank of Commerce", HSBC, MUFG та "State Street") організували проект щодо створення нової криптовалюти - "монети для розрахунків" (utility settlement coin - USC). Після приєднання до проекту "Deutsche Bank", "Banco Santander", "BNY Mellon" та NEX він перейшов на новий рівень, що передбачає обговорення цієї ідеї з центробанками, а також доопрацювання системи захисту конфіденційності даних та захисту від кібератак [10].

Найпоширенішим способом видобутку криптовалюти є майнінг, який здійснюється за рахунок обчислювальної потужності комп'ютерного обладнання.

Завдання техніки - підібрати із мільйонів комбінацій один правильний геш-код, який сформує заголовок блоку в блокчейні. Як тільки необхідне число згенероване, блок зі всіма транзакціями закривається, і майнери переходять до пошуку наступного. За правильний геш-код майнери отримують нагороду - 12,5 біткоїнів. $€$ ще форджинг - спеціальна форма майнінгу з голосуванням - i ICO [11].

Окрім майнінгу, є на сьогодні безліч різних способів заробляти криптовалюту. Основними 3 них є такі:
Таблиця 2. Рейтинг криптовалют по капіталізації станом на 21 березня 2021 року

\begin{tabular}{|c|c|c|c|}
\hline № & Валюта & Ціна USD & Капіталізація USD \\
\hline 1 & Bitcoin & 57300.45 & 1069236003194 \\
\hline 2 & Ethereum & 1792.98 & 206446911068 \\
\hline 3 & Binance Coin & 263.36 & 40698192115 \\
\hline 4 & Tether & 1.00 & 39516191945 \\
\hline 5 & Cardano & 1.20 & 38465997363 \\
\hline 6 & Polkadot & 36.82 & 33957813001 \\
\hline 7 & $\mathrm{XRP}$ & 0.51 & 22971235208 \\
\hline 8 & Uniswap & 32.37 & 16892623485 \\
\hline 9 & Litecoin & 196.67 & 13118113339 \\
\hline 10 & Chainlink & 29.37 & 12175126835 \\
\hline 11 & USD Coin & 1.00 & 9867684063 \\
\hline 12 & Bitcoin Cash & 525.76 & 9824215321 \\
\hline 13 & Stellar & 0.40 & 9103563560 \\
\hline 14 & THETA & 8.74 & 8735914177 \\
\hline 15 & Dogecoin & 0.06 & 7403511852 \\
\hline 16 & VeChain & 0.09 & 5854438075 \\
\hline 17 & Crypto.com Coin & 0.22 & 5571005150 \\
\hline 18 & Cosmos & 20.67 & 4382202519 \\
\hline 19 & TRON & 0.06 & 4331402046 \\
\hline 20 & Monero & 229.84 & 4106753529 \\
\hline 21 & EOS & 4.19 & 3986321390 \\
\hline 22 & IOTA & 1.39 & 3876756050 \\
\hline 23 & Bitcoin SV & 206.10 & 3850653306 \\
\hline 24 & FTX Token & 39.55 & 3731561702 \\
\hline 25 & Kusama & 396.49 & 3358287017 \\
\hline 26 & NEM & 0.36 & 3273077173 \\
\hline 27 & Chiliz & 0.58 & 3247829178 \\
\hline 28 & Binance USD & 1.00 & 3235546070 \\
\hline 29 & Tezos & 4.21 & 3212391428 \\
\hline 30 & Algorand & 1.22 & 3170463463 \\
\hline
\end{tabular}

Ажерело: [1].

1. Крани - це сервіси, які здійснюють роздачу Bitcoin та інших монет за виконання маленьких завдань, наприклад, це може бути розгадування капчі, веб-серфінг і т. ін.

2. Баунті $є$ процесом рекламування нових ICO-проектів за допомогою постингу, репостингу, перекладу. Спочатку ви отримуєте токени безкоштовно, які стануть повноцінною криптовалютою найближчим часом.

3. Постинг / копірайтинг полягає в тому, що учасниками сервісів Steemit i Golos отримується винагорода у вигляді внутрішньої криптовалюти. У подальшому вона обмінюється на біржах.

Bitcoin та інші коїни легко можна придбати через біржі, обмінники, криптомати або навіть безпосередньо. Щоб почати користуватися криптовалютою необхідно створити гаманець [12].

Капіталізація всіх криптовалют разом на початку 2021 р. складала близько 1597601784622 дол. США. У грудні 2017 р. капіталізація ринку криптовалют перетнула позначку 500 млрд дол. 
Таблиця 3. Інституційне забезпечення криптовалюти в світі на прикладі Біткойн

\begin{tabular}{|c|c|c|}
\hline $\begin{array}{l}\text { Відношення до } \\
\text { криптовалюти } \\
\end{array}$ & Інституційне забезпечення & Країна \\
\hline \multirow[t]{9}{*}{ Лояльне } & Приватні гроші, розрахункова одиниця & Німеччина \\
\hline & $\begin{array}{l}\text { Дозволений обіг, проте не є законним } \\
\text { платіжним засобом }\end{array}$ & Хорватія \\
\hline & Біржовий товар & Норвегія \\
\hline & $\begin{array}{l}\text { Операції з криптовалютой } \\
\text { обкладаються 10\% податком }\end{array}$ & Болгарія \\
\hline & Іноземна валюта & Швейцарія \\
\hline & Сировинний товар & Фінляндія \\
\hline & Легальний засіб обміну & $\begin{array}{l}\text { США, Нова Зеландія, } \\
\text { Сінгапур, Іспанія, } \\
\text { Австралія, } \\
\text { Нідерланди } \\
\end{array}$ \\
\hline & Законний платіжний засіб & Японія \\
\hline & Оподатковується як надання послуг & Данія \\
\hline Категоричне & Заборона криптовалюти & $\begin{array}{l}\text { В’єтнам, Бангладеш, } \\
\text { Болівія, Таїланд, } \\
\text { Еквадор }\end{array}$ \\
\hline Очікуваня & $\begin{array}{l}\text { Відсутність заборони на операції } 3 \\
\text { криптовалютою; розглядається як } \\
\text { ризикований і спекулятивний } \\
\text { фінансовий інструмент }\end{array}$ & \begin{tabular}{|l} 
Індія, Російська \\
Федерація, Кіпр, \\
Франція, Україна, \\
Китай \\
\end{tabular} \\
\hline
\end{tabular}

Ажерело: розроблено авторами особисто.

США, проте станом на 02.11.2019 р. знизилась до рівня 247,77 млрд доларів США [1].

Аля ефективності функціонування криптовалют необхідною є їх інституалізація, яку здійснити можна двома шляхами:

- правова інституалізація;

- ринкова, особливість якої полягає в тому, що здійснюється вона завдяки неформальному і формальному встановленню правил функціонування криптовалют.

Варто відмітити, що на міжнародному ринку платежів становище криптовалюти залежить від того, який підхід обирають уряди у регулюванні операцій 3 цією криптовалютою. Інституційне забезпечення по відношенню криптовалюти в світі на прикладі Біткойн відображено в таблиці 3.

Потрібно відмітити, що становище криптовалюти на міжнародному ринку платежів залежить від того, який підхід у регулюванні операцій $з$ цією валютою обирають уряди різних країн.

Країни з лояльною позицією до криптовалюти через фінансові регулятори оподатковують, ліцензують або обмежують розрахунки 3 цією валютою.

Так, у США використовують два підходи до оподаткування операцій у Біткойнах:

1) оподаткування капітального активу (довгострокові інвестиції) за ставкою $15 \%$ від отриманих доходів та короткострокові інвестиції за ставкою $35 \%$;

2) оподаткування операцій з валютою за ставкою $23 \%$. Аанія і Японія регулюють діяль- ність бірж, які торгують цифровою валютою. В Німеччині ліцензуються операції з криптовалютою, дозволений розрахунок у Біткойнах по всій території країни [13]. Так, у низці країн офіційно дозволені операції з Біткойн. Зазвичай вони розглядаються як товар або інвестиційний актив і для цілей оподаткування підпорядковані відповідному законодавству. У деяких країнах (Німеччина, Японія) Біткойн визнають розрахунковою грошовою одиницею [14].

Країни 3 категоричною позицією забороняють будь-які операції з криптовалютою, як загроза стабільності фінансовій системі національних економік. Так, на думку Центрального банку Болівії, валюта, яка не випускається і не контролюється урядом або уповноваженим органом $є$ незаконною [16].

Країни 3 позицією очікування застерігають своїх громадян від використання криптовалюти внаслідок їі ризикованості та спекулятивності, однак здійснення операцій 3 нею не забороняють. Ринок криптовалюти в Україні знаходиться у правовому вакуумі. Наразі найбільш гострою проблемою для України є механізм імплементації поняття криптовалюти у національне законодавство через прийняття відповідних норм у сфері податкового, банківського, цивільного та господарського права. Все більше українських споживачів використовує криптовалюту для on-line купівлі товарів та послуг або ж використовують її як інвестиції з високим рівнем капіталізації [14; 9].

Факт необхідності використання ліквідного потенціалу криптовалюти є цілком очевидним для розвитку національних економік. Більшість розвинутих країн адаптують своє законодавство для регулювання віртуальної валюти, що дозволить поетапно пристосувати інновації фінансового ринку - криптовалюту до сучасних реалій. Прийшов час набуття функціонального, прозорого, дешевого, загальнодоступного, об'єднуючого весь світ грошово-кредитного інструменту, то держава повинна докласти максимум зусиль для правового осмислення і технічного забезпечення діяльності цього інструменту фінансового ринку із здобуттям максимальної вигоди та користі [15]. 3 мето забезпечення ефективності функціонування ринку криптовалюти доцільно розробити організаційно-еконо- 


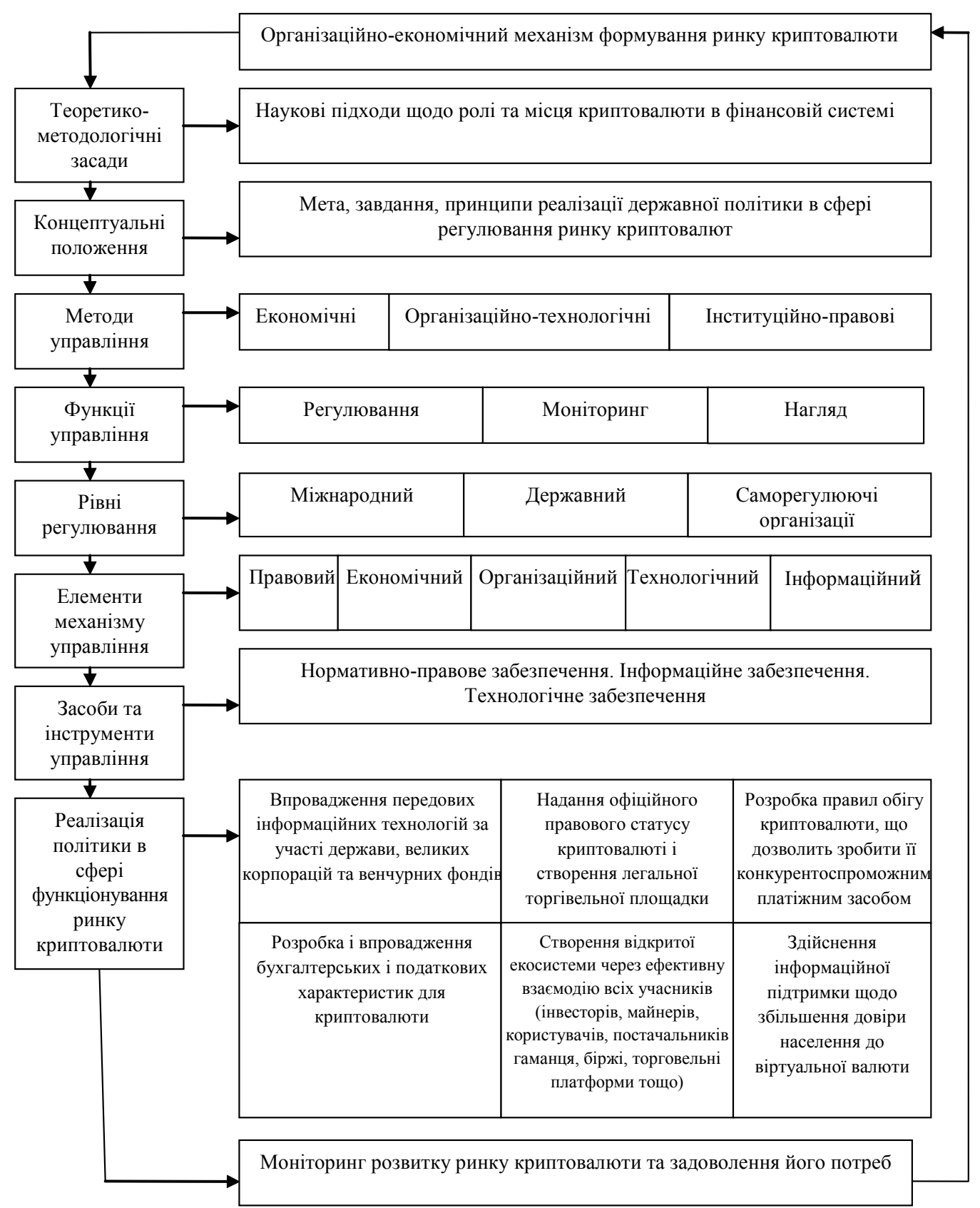

\section{Рис. 1. Організаційно-економічний механізм формування ринку криптовалюти} для країн з позицією очікування

Ажерело: розроблено авторами особисто.

мічний механізм формування ринку криптовалюти для країн з позицією очікування (рис. $1)$.

Ефективність функціонування ринку криптовалюти багато в чому залежить від його структури, взаємодії та узгодженості його елементів (методів, функцій та інструментів управління), які представляють собою складний комплекс. Описані особливості функціонування криптовалюти, особливості її емісії та придбання суттєво відрізняються від особливостей функціонування фіатних валют. У 2021 році (21.03.2021 р.) ринкова капіталізація криптова- лют у світі становить 1597601784622 дол. США, при цьому $80 \%$ цієї суми припадають на десятку лідерів рейтингу цифрових валют, таких як Bitcoin, Bitcoin Cash, Ethereum, Ripple, EOS, Litecoin, Stellar lumens, Neo, Dash i TRON. Однак, як і будь-яке інше нове явище, криптовалюта викликає чимало сумнівів, таких як втрата пароля або доступу до електронного гаманця, можливість хакерських атак, неможливість внесення до статутного капіталу юридичних осіб. Попри це, пересічні споживачі продовжують інвестувати в цю валюту, збільшуючи її капіталізацію. 


\section{ВИСНОВКИ}

1. Узагальнюючи різні дефініції, можна позиціонувати криптовалюту як універсальний світовий засіб платежу, обігу та інвестування, що існує у вигляді програмного коду з високим ступенем захищеності і характеризується вільним ринковим курсом.

Криптовалюта стає все більш важливою частиною суспільства і роботи техніки по всьому світу. Кількість людей, які використовують криптовалюту, зросла і наближається до населення невеликої країни - від 2,9 до 5,8 мільйона чоловік. Більшість $є$ жителями Північної Америки і Європи.

2. На сьогодні основними ознаками криптовалюти є: децентралізованість, можливість виступати платіжним засобом, високий ступінь ліквідності, подільність, портативність, відсутність ознак матеріального світу, прозорість, відсутність єдиного емітента.

Основні відмінності електронних грошей від криптовалюти розділено за такими критеріями, як доступність, ступінь ідентифікації користувача цінність, виробництво, емітент, регулювання.

3. Аля ефективного функціонування криптовалюти необхідна їх інституалізація, яку можна здійснити двома шляхами: по-перше, це правова інституалізація, а по-друге - ринкова, яка здійснюється завдяки формальному і неформальному встановленню правил функціонування криптовалюти.

4. Обгрунтовано різний підхід країн до правового статусу криптовалют - одні країни визнали доцільність їх використання та працюють над формуванням правової бази, яка б закріпила правовий статус віртуальних валют, а інші країни - забороняють або обмежують обіг криптовалюти.

5. Розроблено організаційно-економічний механізм формування ринку криптовалюти для країн з позицією очікування, в основу якого закладено функції, методи та інструменти управління за допомогою яких досягається функціонування ринку криптовалюти в якості взаємоузгоджених і взаємодоповнюючих елементів єдиної фінансової системи світу, що дало змогу запропонувати напрями реалізації політики в сфері функціонування ринку криптовалюти для країн з позицією очікування:

- впровадження передових інформаційних технологій за участі держави, великих корпорацій та венчурних фондів;

- надання офіційного правового статусу криптовалюті і створення легальної торгівельної площадки для її обігу;
- розробка правил обігу криптовалюти, що дозволить зробити її конкурентоспроможним платіжним засобом;

- розробка і впровадження бухгалтерських і податкових характеристик для криптовалюти;

- створення відкритої екосистеми через ефективну взаємодію всіх учасників (інвесторів, майнерів, користувачів, постачальників гаманця, біржі, торговельні платформи тощо);

- здійснення інформаційної підтримки щодо збільшення довіри населення до віртуальної валюти.

\section{$\Lambda$ ітература:}

1. CoinMarketCap. Available from: https:// coinmarketcap.com/historical

2. Bohme R. Bitcoin: Economics, Technology, and Governance / RainerBohme, Nicolas Christin, Benjamin Edelman, Tyler Moore // The Journal of Economic Perspectivess. 2015. Vol. 29. — № 2. P. 213-238.

3. Schultz R. What Influences the Price of Bitcoin: 2011-2015 [Electronic resource] / Richard Schultz// Senior Thesis in Economics. 2016. Available from: https://business.tcnj.edu/ files/2016/11/2016.schultz.richard.ThesisFinal.revised.s16.pdf

4. Vassiliadis S. Bitcoin value analysis based on cross-correlations [Electronic resource]/ Savvas Vassiliadis, Perikles Papadopoulos, Maria Rangoussi, Tomasz Konieczny, Jacek Gralewski / / Journal of Internet Banking and Commerce. Jan 2017. vol. 22. no. S7. Available from: http:// www.icommercecentral.com/open-access/bitcoin-value-analysis-based-on-crosscorrelations.pdf

5. Николайчук О. Электронная валюта в свете современных правовых и экономических вызовов. Journal of Economic Regulation. 2017. T. 8, № 1. С. 142-154.

6. Аемиргуч-Кунт А., Клэппер $\Lambda$. (2012). Аоступ к банковским услугам. Международный Валютный Фонд. Available from: https:// www.imf.org/external/russian/pubs/ft/fandd/ 2012/09/pdf/picture.pdf

7. Петрук О.М., Новак О.С. Сутність криптовалюти як методологічна передумова іiї облікового відображення. Economics, Management and Administration. 2017. № 4 (82). C. 48-55.

8. Спільна заява фінансових регуляторів щодо статусу криптовалют в Україні. Available from: https://bank.gov.ua/control/uk/publish/ article?art

9. Биржа для обмена виртуальной валюты нашла инвесторов: веб-сайт. Available from: 
http://www.vedomosti.ru/tech/news/11932001/

5_mln_za_virtualnuyu_valyutu

10. Біткоін та інші криптовалюти: ризики та перспективи використання в Україні. Available from: http://www.niss.gov.ua

11. Макарчук I.M., Перчук О.В., Малишко В.В. Перспективи використання криптовалют у сучасних економічних системах. Economics, Management and Administration. 2019. № 2 (88). C. $179-185$.

12. Що таке криптовалюта простими словами. Available from: https://cryptota.com.ua/ shcho-take-kryptovaliuta-prostymy-slovamy/

13. Аук'янов В.С. Зародження ринку криптовалюти в інформаційно-мережевій парадигмі. Актуальні проблеми економіки. 2014. № 8 (158). C. 436-441.

14.Carnes B. Ukraine Is Silently Leading A Digital Currency Revolution/ Ben Carnes. 2017/ Офіційний сайт Forbes. Available from: https:// www.forbes.com/sites/realspin/2017/03/20/ ukraine-is-silently-leading-a-digital-currencyrevolution/\#4d0ef946465c

15. Система біткоін: плюси і мінуси. Invest Program, 2015. Available from: http://investprogram.com.ua/tag/bitkoin/

16. Криптовалюти та їх місце у фінансовій системі. Available from: https://knute.edu.ua/ file/ $\mathrm{NjY} 4 \mathrm{NQ}==/ 02 \mathrm{~d} 193 \mathrm{~b} 6 \mathrm{~b} 501 \mathrm{a} 0 \mathrm{fd} 82 \mathrm{~d} 6$ 798fc841e70b.PDF

\section{References:}

1. CoinMarketCap (2021), "Historical Snapshot", Available at https://coinmarketcap.com/historical (Accessed 20 March 2021).

2. Bohme, R. Christin, N. Edelman, B. and Moore, T. (2015), "Bitcoin: economics, technology and governance", The Journal of Economic Perspectivess, vol. 29, No. 2, pp. 213-238. DOI:https://doi.org/10.1257/jep.29.2.213

3. Schultz, R. (2016), "What Influences the Price of Bitcoin: 2011-2015", Senior Thesis in Economics, Available at: https://business. tcnj.edu/files/2016/11/2016.schultz.richard.ThesisFinal.revised.s16.pdf (Accessed 20 March 2021).

4. Vassiliadis, S. Papadopoulos, P. Rangoussi, M. Konieczny, T. and Gralewski, J. (2017), "Bitcoin value analysis based on cross-correlations", Journal of Internet Banking and Commerce, vol. 22, No. S7, pp. 2-12.

5. Nikolaychuk, O.A. (2017), "Electronic currency in the ligh to modern legal and economic challenges", Journal of Economic Regulation, vol. 8, No. 1, pp. 142-154. DOI: $10.17835 / 2078-$ 5429.2017.8.1.142-154
6. Demirguch-Kunt, A, \&Klepper, L. (2012), "Access to banking services", International Monetary Fund, Available at: https://www.imf.org/ external/russian/pubs/ft/fandd/2012/09/pdf/ picture.pdf (Accessed 20 March 2021).

7. Petruk, O. M. and Novak, O. S. (2017), "The essence of cryptanalytic as a methodological prerequisite accounting reflection", Journal IGTU, vol. 4 (82), pp. 48-55. DOI: https://doi.org/ 10.26642/jen-2017-4(82)-48-55.

8. The official site of the National Bank of Ukraine (2018), "Joint statement of financial regulators regarding the status of cryptocurrencies in Ukraine (2017)", Available at: https:// bank.gov.ua/control/uk/publish/article?art (Accessed 20 March 2021).

9. Popikov, A.A. (2016), "Bitcoin cryptocurren cyas a financialins trument of the virtual economy", Journal of Innovation Economics, vol. 6 (2),pp. 89-106. DOI: https://doi.org/10.18334/ vinec.6.2.35354.

10. National institute for strategic studies (2018), "Bitcoin and other cryptocurrencies: risks and prospects of using in Ukraine. Analytical note", Available at: https://niss.gov.ua/sites/default/ files/2018-05/Glakih_bitcoin-34ba 8.pdfa (Accessed 20 March 2021).

11. Makarchuk, I.M. Perchuk, O.V. and Malyshko, V.V. (2019). "Prospects for using cryptocurrencies in modern economic systems", Journal IGTU, vol. 2 (88), pp. 179-185. DOI: https://doi.org/10.26642/jen-2019-2(88)-179-185.

12. cryptota.com.ua (2021), "What is cryptocurrency in simple words", Available at: https:// cryptota.com.ua/shcho-take-kryptovaliutaprostymy-slovamy/ (Accessed 20 March 2021).

13. Lukyanov, V.S. (2014), "Cryptocurren cymarketes tablishment with in information network kparadigm", Actual problems of economics, Vol. 8 (158), pp. 436-441.

14.The official site of Forbes,Carnes, B. (2017), "Ukraine Is Silently Leading A Digital Currency Revolution", Available at: https://www.forbes. com/ sites/realspin/2017/03/20/ukraine-issilently-leading-a-digital-currencyrevolution/ \#4d0ef946465c (Accessed 20 March 2021).

15. InvestProgram (2015), "Bitcoin system: pros and cons", Available at: http://invest-program.com.ua/tag/bitkoin/ (Accessed 20 March 2021).

16. Kyiv NationalUniversity of Trade and Economics (2018), "Cryptocurrencies and their place in the financial system", available at: https:// knute.edu.ua/file/NjY4NQ==/02d193b6b501a0fd82d6798fc841e70b.PDF (Accessed 02 March 2021). Стаття надійшла до редакиї 22.03.2021 p. 
УAK 331.108:338.512:338.24

\author{
А. С. Олійник, \\ к. е. н., старший викладач кафедри менеАжменту, \\ Полтавська державна аграрна академія, м. Полтава \\ ORCID ID: 0000-0002-0274-5204 \\ М. Б. Вельбой, \\ зАобувач вищої освіти спеціальності "Менеджмент", \\ Полтавська державна аграрна академія, м. Полтава \\ ORCID ID: 0000-0003-1135-611X \\ Н. М. $А$ ук'яовець, \\ здобувач вищої освіти спеціальності "Менеджмент", \\ Полтавська державна аграрна академія, м. Полтава \\ ORCID ID: 0000-0001-9750-4018
}

DOI: $10.32702 / 2306-6792.2021 .7-8.94$

\title{
РОАЬ ПЕРСОНАЛУ ТА ВИРОБНИЧИХ ВИТРАТ ПРИ ЕФЕКТИВНОМУ УПРАВАІННІ ПІАПРИЕМСТВОМ
}

\author{
A. Oliinyk, \\ $\mathrm{PhD}$ in Economics, Senior Lecturer of the Department of Management, \\ Poltava State Agrarian Academy, Poltava \\ M. Velboi, \\ applicant for higher education specialty Management, Poltava State Agrarian Academy, Poltava \\ N. Lukianovets, \\ applicant for higher education specialty Management, Poltava State Agrarian Academy, Poltava
}

\section{THE ROLE OF PERSONNEL AND PRODUCTION COSTS IN EFFECTIVE MANAGEMENT OF THE ENTERPRISE}

У статті з'ясовано основні перепони ефективного використання персоналу. Аосліджено взаємодію складових ефективного управління персоналом. Зазначено показники організаційної, економічної та соціальної ефективності управління персоналом. Виокремлено вагомі принципи ефективного використання персоналу. Проаналізовано формування виробничих витрат. Наведено системний підхід до управління виробничими витратами. Аргументовано, що головною метою системи управління виробничими витратами є створення їх оптимальної структури і величини, що гарантуватиме ефективність і прибутковість виробничої діяльності. Запропоновано проектну модель системи управління витратами виробництва та створення центрів відповідальності для удосконалення фінансової структури підприємства. Розроблено алгоритм формування системи управління виробничими витратами. Аоведено, що незалежно від специфіки господарської діяльності порядок створення системи управління виробничими витратами має охоплювати етапи націлені на формування результативних центрів витрат та створення ефективних центрів відповідальності.

The article identifies the main obstacles to the effective use of staff. It is noted that the effective use of personnel in enterprises requires the influence and participation of capable, talented managers at the initial stage, which requires addressing the natural resistance to change, some barriers of psychological rejection in the implementation of new projects and non-traditional management activities. The interaction of components of effective personnel management is investigated. All three components of human resource management are closely interrelated and interact, but there is some benefit to organizational efficiency. This is justified by the fact that management decisions are transformed into specific organizational measures. With a clear organization of labor and production, and hence the rational use of production resources increases the economic performance of the enterprise, thereby creating financial opportunities to increase the quality of working life of staff, which is a manifestation of effective personnel management. If the material, socio-psychological, organizational, moral and ethical and other working conditions of staff are improved, it is necessarily reflected in the further increase of economic and organizational efficiency of personnel management. Indicators of organizational, economic and social efficiency of personnel management are indicated. Important principles of effective 
use of personnel are highlighted. The formation of production costs is analyzed A systematic approach to cost management is presented. It is argued that the main purpose of the production cost management system is to create their optimal structure and size, which will guarantee the efficiency and profitability of production activities. It is investigated that the basis of the cost management system is information about the production activities of the enterprise and external changes, and the result is the rationality of the cost management system, which forms and ensures the efficiency of the entire enterprise. Cost centers in relation to the management apparatus are the object of management, and on the other hand, in relation to costs is the subject of management, which implements the functions of the cost management system, which in turn are implemented through certain methods and tools. The project model of the production cost management system and the creation of responsibility centers to improve the financial structure of the enterprise is proposed. An algorithm for forming a production cost management system has been developed. It is proved that regardless of the specifics of economic activity, the procedure for creating a production cost management system should cover the stages aimed at forming effective cost centers and creating effective centers of responsibility.

Ключові слова: персонал, використання персоналу, управління персоналом, виробничі витрати, иентри витрат, иентри відповідальності, оптимізачіл витрат, контролінг.

Key words: personnel, use of personnel, personnel management, production costs, cost centers, responsibility centers, cost optimization, controlling.

\section{ПОСТАНОВКА ПРОБЛЕМИ У ЗАГАЛЬНОМУ ВИГЛЯДІ ТА ІІЇ ЗВ'ЯЗОК ІЗ ВАЖЛИВИМИ НАУКОВИМИ ЧИ ПРАКТИЧНИМИ ЗАВДАННЯМИ}

Сучасні економічні перетворення, що відбуваються в Україні, пов'язані з пошуком нових методів управління персоналом та виробничими витратами на підприємстві, адже саме від цих складових залежить формування виробничого процесу, ефективне управління підприємством.

Підготовка компетентного персоналу, його раціональне просторове та структурне розміщення, результативна культура управління, і $€$ запорукою досягнення успіху підприємства. Без кваліфікованих і мотивованих працівників не в змозі ефективно працювати системи маркетингу, логістики, продажу, фінансів тощо. Роль та місце персоналу особливо важливе у нинішніх умовах глобальної конкуренції, стрімкого науково-технічного прогресу, тоді коли продукти, технології, операційні методи та навіть організаційні структури швидко старіють, а знання та навички працівників стають вагомим джерелом постійного розвитку підприємств.

Важливим елементом діяльності будь-якого суб'єкта господарювання є і виробничі витрати, які відображають конкурентоспроможність, економічну стійкість та ефективність виробництва. Виробничі витрати мають прямий вплив і на функціонування, і на розвиток підприємства, тому оптимальне управління виробничими витратами $є$ актуальним як науковим, так і практичним завданням.

\section{АНАЛІЗ ОСТАННІХ ДОСЛІДЖЕНЬ І ПУБЛІКАЦІЙ, В ЯКИХ ЗАПОЧАТКОВАНО РОЗВ'ЯЗАННЯ ДАНОЇ ПРОБЛЕМИ I НА ЯКІ СПИРАЄТЬСЯ АВТОР, ВИДІЛЕННЯ НЕ ВИРІШЕНИХ РАНІШЕ ЧАСТИН ЗАГАЛЬНОЇ ПРОБЛЕМИ, КОТРИМ ПРИСВЯЧУЄТЬСЯ ОЗНАЧЕНА СТАТТЯ}

Аспекти теорії та практики ролі персоналу та виробничих витрат розглядали у своїх працях А.О. Азарова, А.В. Балабанова, М.С. Вороніна, М.А. Виноградський, А.М. Колот, Ф.Ф. Бутинець, І.Є. Аавидович, А.Г. Цимбалюк, Ю.С. ЦалЦалко, А.В. Череп, Г.В. Черевко, М.І. Шваб та інші. Однак неоднозначність поглядів на роль персоналу та оптимізацію виробничих витрат при ефективному управлінні підприємством потребує ще більш чіткої деталізації.

\section{META CTATTI}

Метою статті $€$ дослідження і обгрунтування ролі персоналу та виробничих витрат за ефективного управління підприємством.

\section{ВИКЛАД ОСНОВНОГО МАТЕРІАЛУ ДОСЛІДЖЕННЯ 3 ПОВНИМ ОБГРУНТУВАННЯМ ОТРИМАНИХ НАУКОВИХ РЕЗУЛЬТАТІВ}

Формування стійких конкурентних переваг як економіки, загалом, так і конкретного підприємства, можливе лише при умові ефективного, раціонального використання персоналу підприємств. Практика функціонування підприємств підтверджує, що послідовність принципів та методів залучення і використання людського капіталу забезпечує отримання 
взаємовіддачі, збільшення прибутковість, підвищення рівня отримання соціальноекономічного ефекту [8].

У нинішніх умовах господарювання більшість керівників визнають, що конкурентну перевагу підприєм- । ства відображає перевага ! персоналу цього підприєм- । ства відносно інших. Нове ! обладнання, сировина, техніка будь-якої якості доступні всім конкурентам на ринку, тому такі особливості персоналу, як їх знання, кваліфікація, рівень підготовки, постійний розвиток тощо можуть стати голосною перевагою серед конку-

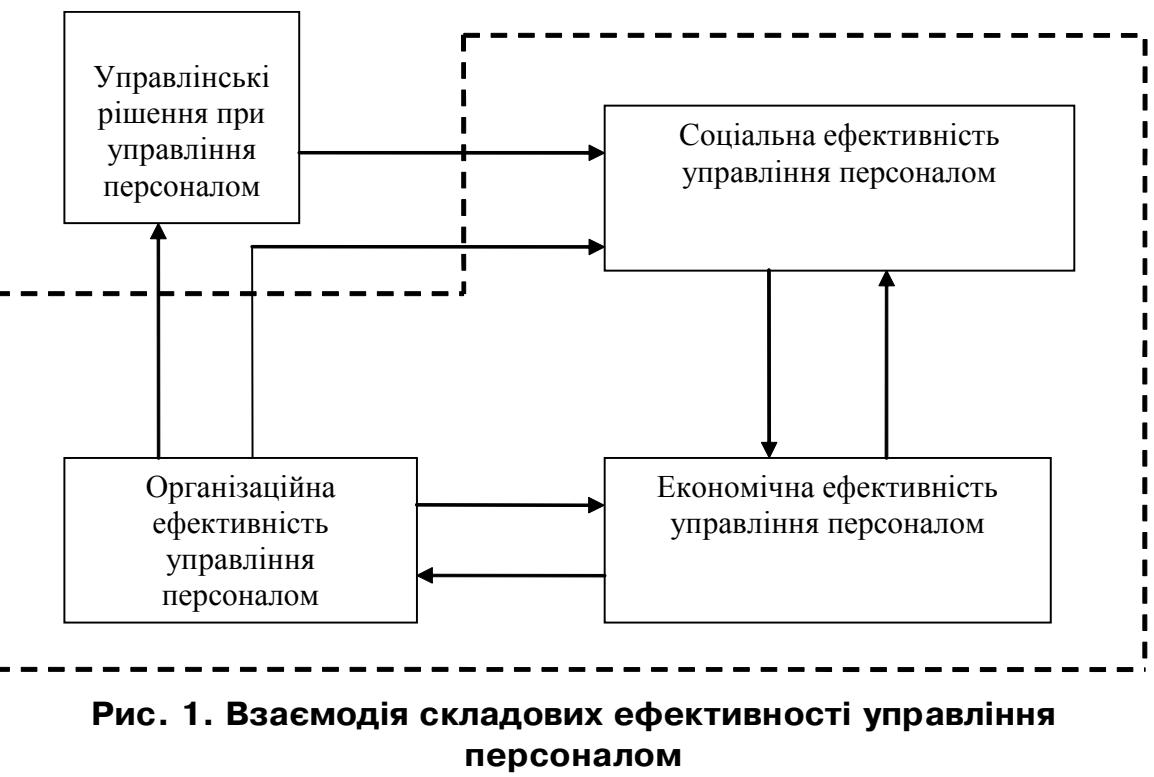
рентів [14].

В умовах сучасних трансформацій $є$ перешкоди, які заважають руху вперед та негативно відображаються на економіці підприємства, держави. Ао основних перепон ефективного використання персоналу можна віднести [4]:

- неадаптованість до мінливих умов господарювання;

- негнучкість системи управління;

- невміння враховувати вплив зовнішніх факторів;

- історично сформований трудовий менталітет;

- відрив планування розвитку кадрового потенціалу на підприємствах від реальної ситуації щодо формування кадрового потенціалу в певному регіоні;

- кадровий дефіцит, який зростає внаслідок збільшення обсягів трудової міграції в інші країни, де на підприємствах пропонується більш приваблива заробітна плата;

- невідповідність обсягів та структури кадрів кадровим потребам;

- якість підготовки кадрів у регіонах не влаштовує менеджерів підприємств.

Здійснення ефективного використання персоналу на підприємствах вимагає впливу та участі здібних, талановитих менеджерів на початковому етапі, який вимагає вирішення закономірного опору змінам, деяким бар'єрам психологічного несприйняття під час впровадження нових проектів і нетрадиційних для працівників заходів у сфері управління.

Відтак ефективність управління персоналом слід розуміти як рівень якості, корисності управління людськими ресурсами та здатність

функціонування троїстого ефекту у вигляді економічної вигоди для підприємства, удосконалення організації виробництва і соціальної вигоди для співробітників.

Усі три складові (економічна, організаційна і соціальна) ефективності управління персоналом тісно взаємопов'язані і взаємодіють між собою, однак певна перевага належить організаційній ефективності. Це обгрунтовується тим, що управлінські рішення трансформуються у конкретні організаційні заходи. За чіткої організації праці та виробництва, а отже, раціональному використанню виробничих ресурсів підвищуються економічні показники господарської діяльності підприємства, тим самим створюються фінансові можливості для збільшення якості трудового життя персоналу (підвищення трудових доходів, удосконалення умов праці), що є проявом ефективності управління персоналом. Якщо матеріальні, соціальнопсихологічні, організаційні, морально-етичні та інші умови роботи персоналу удосконалюються, то це обов'язково відображається на подальшому підвищенні економічної, організаційної ефективності управління персоналом. Цей взаємозв'язок складових ефективності управління персоналом зображено на рисунку 1 [11].

Важливою передумовою забезпечення економічної ефективності управління персоналом $€$ формування адекватного організаційного рівня управління персоналом. Серед основних показників організаційної ефективності управління персоналом слід виділити:

- стан забезпечення підприємства персоналом за спеціальностями, професіями, посадами, освітньо-кваліфікаційними рівнями; 
- ефективність використання робочого часу, кваліфікації та творчого потенціалу;

— якість продукції та послуг;

- ритмічність виробництва.

Організаційна ефективність управління персоналом досягається щоденною наполегливою роботою у напрямках:

- високоякісного інформаційного забезпечення (стандарти, нормативно-правові акти, організаційно-розпорядчі документи тощо);

- підбору, комплектуванні та розстановці кадрів, делегуванні повноважень, поділу та кооперуванні праці; місць;

- організації та обслуговуванні робочих

- створенні сприятливих умов праці;

- ефективного моніторингу ритмічності виробництва;

- звітності, обліку та контролю результатів виробництва.

Визначальним чинником економічної ефективності управління персоналом $€$ передусім діагностика якісних характеристик працівників та загального рівня управління. У процесі економічної ефективності управління персоналу обов'язково потрібно аналізувати динаміку співвідношення балансового прибутку та сукупних витрат на оплату праці, а також оцінювати як змінюється частка витрат на оплату праці у загальній сукупності витрат виробництва. Якщо при суміжних періодах спостерігається позитивна динаміка прибутку відносно витрат на персонал, прибутку та витрат на оплату праці, якщо збільшується частка витрат на оплату праці у загальній сукупності виробничих витрат, то це свідчить про ефективну політику трудових доходів та результативні організацію оплати праці.

Показниками для оцінки економічної ефективності управління персоналом є:

- співвідношення витрат, потрібних для забезпечення підприємства кваліфікованими кадрами, та результатів, отриманих від їхньої діяльності;

- відношення бюджету підрозділів підприємства до чисельності персоналу цих підрозділів;

- вартісна оцінка розходжень у результативності праці.

Ці показники орієнтують персонал на виконання планових завдань, раціональне використання робочого часу, поліпшення трудової і виконавської дисципліни, покращення організації праці.

Зростання продуктивності, рентабельності, збільшення маси прибутку, виконання всіх
Таблиця 1. Основні принципи ефективного використання персоналу

\begin{tabular}{|l|l|}
\hline \multicolumn{1}{|c|}{ Принцип } & \multicolumn{1}{c|}{ Зміст } \\
\hline $\begin{array}{l}\text { Корисності та } \\
\text { раціональності }\end{array}$ & $\begin{array}{l}\text { Розташування персоналу по робочим місцях } \\
\text { згідно з освітніми, кваліфікаційними даними, а } \\
\text { також соціально-психологічними особливостями }\end{array}$ \\
\hline $\begin{array}{l}\text { Врахування } \\
\text { ринкових } \\
\text { факторів }\end{array}$ & $\begin{array}{l}\text { Залучення та використання персоналу згідно 3 } \\
\text { кон'юнктурою товару «робоча сила» на ринку } \\
\text { праці, реального попиту щодо ї використання } \\
\text { на виробництві }\end{array}$ \\
\hline $\begin{array}{l}\text { Залучення } \\
\text { персоналу }\end{array}$ & $\begin{array}{l}\text { Залучення персоналу згідно з урівноваженим } \\
\text { рівнем обслуговування, тобто повне задоволення } \\
\text { вимог споживачів продукції (послуг) термінами, } \\
\text { надійністю, параметрами, якістю, дизайном, } \\
\text { просуванням на ринок тощо }\end{array}$ \\
\hline $\begin{array}{l}\text { Мінімуму } \\
\text { повних витрат }\end{array}$ & $\begin{array}{l}\text { Передбачає економне та раціональне } \\
\text { використання усіх витрат на управління та } \\
\text { розвиток персоналу }\end{array}$ \\
\hline $\begin{array}{l}\text { Мобільності } \\
\text { персоналу }\end{array}$ & $\begin{array}{l}\text { Здатність швидко пристосовуватися до мінливих } \\
\text { умов маркетингового середовища, до зміни } \\
\text { трудових функцій, змісту праці і т.д. }\end{array}$ \\
\hline $\begin{array}{l}\text { Ефективності } \\
\text { витрат на } \\
\text { управління } \\
\text { персоналом }\end{array}$ & $\begin{array}{l}\text { Формування та розвиток персоналу, що відповідає } \\
\text { забезпеченню субституціональності персоналу як } \\
\text { товару «робоча сила» та забезпечує системну } \\
\text { витратну оптимізацію }\end{array}$ \\
\hline
\end{tabular}

Ажерело: [2].

планів виробництва та реалізації продукції усі ці показники відображають як високий рівень управління підприємством, так і економічну ефективність управління персоналом.

Щодо соціальної ефективності управління персоналом, то вона відображає аспекти привабливості чи непривабливості роботи, задоволеності чи незадоволеності трудового колективу у широкому аспекті.

Показниками соціальної ефективності управління персоналу є:

— динаміка збільшення реальної заробітної плати найманих працівників;

- стабільність кадрового складу;

- гарантії зайнятості (відсутність загрози втратити роботу);

- культурно-побутове обслуговування та стан умов праці;

- професійно-кваліфікаційне просування;

- рівень соціального страхування;

- соціально-психологічний клімат.

Раціональне використання персоналу на підприємствах повинне передбачати реалізацію відповідних принципів (табл. 1).

Іншою вагомою складовою результативного управління як персоналом, так і всього підприємства є виробничі витрати.

Виробничий потенціал певним чином впливає на величину витрат підприємства. Причому величина підприємства передусім відбивається саме на величині змінних витрат, формуючи тим самим загальну величину сукупних витрат на виробництво продукції. Безпосереднім фактором, що впливає на величину вит- 
Таблиця 2. Системний підхід до управління виробничими витратами

\begin{tabular}{|l|l|}
\hline \multicolumn{1}{|c|}{ Назва } & \multicolumn{1}{|c|}{ Зміст } \\
\hline Ієрархічність & $\begin{array}{l}\text { Деякі елементи системи управління витрат } \\
\text { належать одночасно до декількох систем } \\
\text { управління фермерським господарством }\end{array}$ \\
\hline Повнота & $\begin{array}{l}\text { Система охоплює потрібну кількість елементів, } \\
\text { які є взаємодоповнюючі та забезпечують } \\
\text { ефективність процесу управління виробничими } \\
\text { витратами }\end{array}$ \\
\hline Детермінованість & $\begin{array}{l}\text { Система функціонує під впливом факторів при } \\
\text { наявності причинно-наслідкових зв'язків }\end{array}$ \\
\hline Синергічність & $\begin{array}{l}\text { Система управління витратами має певні } \\
\text { властивостні особливості, що не характерні } \\
\text { окремим елементам }\end{array}$ \\
\hline Системні характеристики \\
\hline Адаптивність & $\begin{array}{l}\text { Підготовленість системи управління витрат до } \\
\text { впливу зовнішніх змін }\end{array}$ \\
\hline Динамічність & Часові зміни \\
\hline Надійність & $\begin{array}{l}\text { Безперервність робочого процесу при } \\
\text { порушенні елементів }\end{array}$ \\
\hline Емерджентність & $\begin{array}{l}\text { Центри відповідальності мають деякі конкретні } \\
\text { цілі діяльності, однак вони не суперечать і } \\
\text { забезпечують ефективне управління витратами }\end{array}$ \\
\hline Цілісність & $\begin{array}{l}\text { Не елементи створюють систему управління } \\
\text { витратами, а система формується за } \\
\text { відношенням до елементів }\end{array}$ \\
\hline Цілеспрямованість & $\begin{array}{l}\text { Ефаємодія з іншими системами та елементами } \\
\text { управління } \\
\text { результативної діяльності фермерського } \\
\text { господарства в цілому }\end{array}$ \\
\hline Освіченість & $\begin{array}{l}\text { Здібність вдосконалюватися відносно змін } \\
\text { навколишнього середовища }\end{array}$ \\
\hline
\end{tabular}

Ажерело: [1; 12].

рат є структура виробничої програми - асортимент видів продукції [5].

Важливою особливістю формування виробничих витрат є також значна тривалість виробничого циклу, що вимагає поступового накопичення витрат у незавершеному виробництві, уповільнення оборотності капіталу, що призводить до подорожчання ресурсів.

Істотним фактором, що впливає на формування витрат є організація виробництва, тобто форма його здійснення, яка досить тісно пов'язана з технологією виробничого процесу. Ще одним вагомим фактором формування витрат виробництва $є$ якість виробництва, яка характеризується властивостями факторів виробництва, що визначають їх придатність для використання у виробничому процесі. Підприємство, у якого в розпорядженні $€$ краще технологічне обладнання, персонал з високим рівнем продуктивності праці, сприятливі щодо витрат, умови виконання виробничої програми, зосереджене на відборі факторів виробництва такої якості, при якій витрати на одиницю продукції були б мінімальними [3].

Цінові фактори виробництва безпосередньо впливають на витрати, якщо їх величина у натуральній формі залишається незмінною, то ціни на певні фактори змінюються. Підвищення тарифів на електроенергію призводить до зростання витрат на експлуатацію обладнання. Разом цінові фактори можуть опосередковано впливати на витрати через зміни співвідношення витрат різних чинників. Якщо, наприклад, умови виробництва дозволяють змінювати ресурси, то при підвищенні цін на певні фактори виробництва, вони можуть бути замінені певною мірою іншими факторами 3 прийнятними цінами [10].

Підприємства є складними комплексами, які функціонують завдяки ефективному механізму управління. Витрати виробництва відображають складний об'єкт відносно механізму управління. Однак доцільніше розглядати не механізм, а систему управління, оскільки вона $є$ більш ширшою, і охоплює як суб'єкт та об'єкт управління, а також усі взаємозв'язки у середині та за межами системи [7].

Головною метою системи управління витратами виробництва є створення їх оптимальної структури і величини, що гарантуватиме ефективність і прибутковість виробничої діяльності. Система управління витратами здійснює формування собівартості продукції, визначає резерви зменшення витрат, займається контролем витрат тощо. 


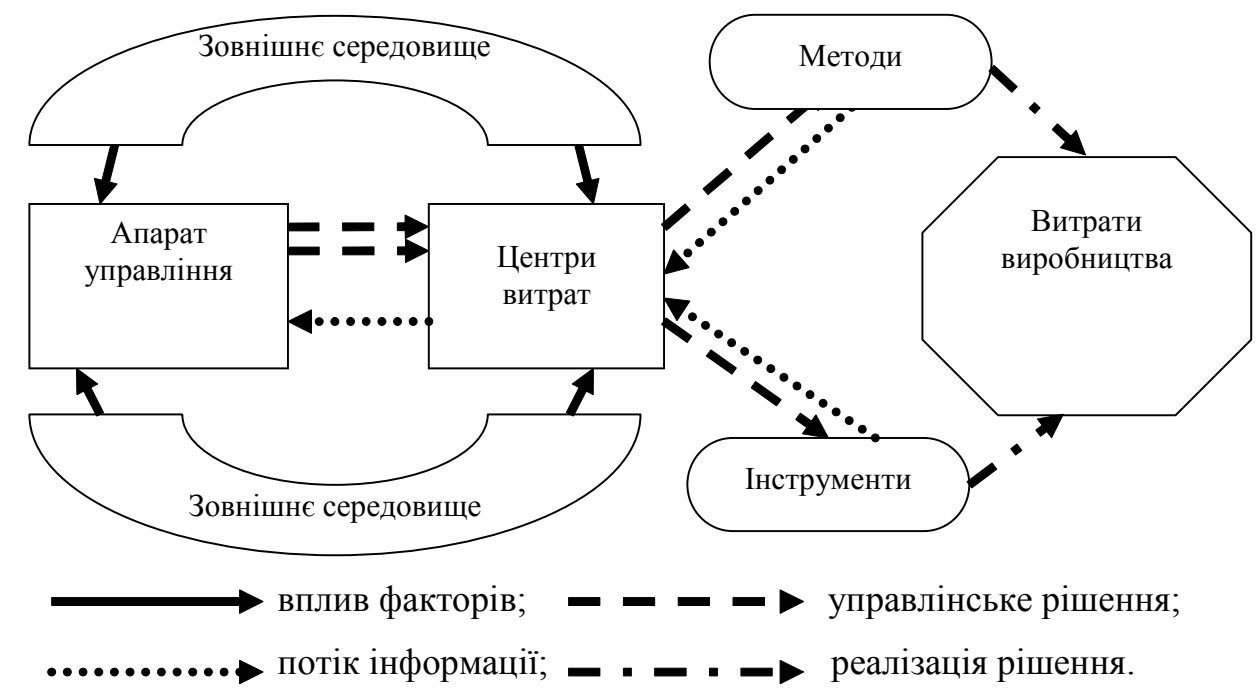

Рис. 2. Проектна модель системи управління витратами виробництва

Ажерело: [9; 13].

Оскільки система управління виробничими витратами є відкритим комплексом, то вона функціонує під впливом зовнішніх та внутрішніх факторів, а принцип адаптивності дозволяє їй своєчасно реагувати та ефективно функціонувати, при змінах як у середині підприємства, так і зовні, зберігаючи існуючі властивості та характеристики.

Системність управління витратами грунтується на основних чотирьох властивостях, інші властивості є додатковими, деякою мірою вони виступають характеристиками основних, тому і виникає потреба використання системного підходу (табл. 2).

Система управління витратами охоплює апарат управління фінансовою діяльністю (суб'єкт управління), витрати на виробництво, центри витрат (об'єкт управління), а також організацію, планування, аналіз, облік, контроль, координацію витрат, мотивацію до оптимізації витрат (функції управління) (рис. 2).

Підгрунтям функціонування системи управління витратами виступає інформація як про виробничу діяльність підприємства, так і про зовнішні зміни, а результатом є раціональність системи управління витратами, що формує та забезпечує ефективність функціонування всього підприємства. Центри витрат відносно апарату управління виступають об'єктом управління, а з іншого боку, відносно витрат є суб'єктом управління, які реалізують функції системи управління витратами, які в свою чергу реалізуються через певні методи та інструменти.

Збереження характеристик і властивостей системи управління виробничими витратами підприємства переважно зумовлене внутрішньою складовою. Звідси і слідує те, що базою ефективного функціонування системи управління витратами $€$ формування її головних елементів і взаємозв'язків між ними.

Найвагомішими елементами (з точки зору їх створення та забезпечення процесу функціонування) є центри витрат системи управління витратами. Процес їх створення взаємопов'язаний з класифікацією виробничих витрат за ознакою поділу на прямі та непрямі витрати щодо процесу виробництва та на контрольовані та неконтрольовані відносно процесу управління [12].

Створення центрів відповідальності відображає удосконалення фінансової структури підприємства за рахунок аналізу та коригування організаційної структури. Аеякі елементи організаційної структури можуть зберегтися i перенестись у фінансову структуру, інші елементи можуть бути об'єднані чи перерозподілені. Основним принципом групування та поділу є можливість контролювання витрат у центрах відповідальності (рис. 3).

Аля ефективного управління виробничими витратами виникає необхідність і у випереджаючій функції, оскільки більшість витрат є безповоротніми, тому рішення про оптимізацію доцільно приймати ще до їх виникнення або під час формування. Випереджаюча функція управління витратами утворює деякі наслідки для такої стратегії. Адже потреба у прийнятті оперативних управлінських рішень на різних етапах операційного циклу зумовлює зростання рівня децентралізації управління, делегування окремих управлінських повноважень керівникам центрів відповідальності. Зосередження усіх управлінських рішень на найвищому рівні апарату управління призводить до уповільнен- 


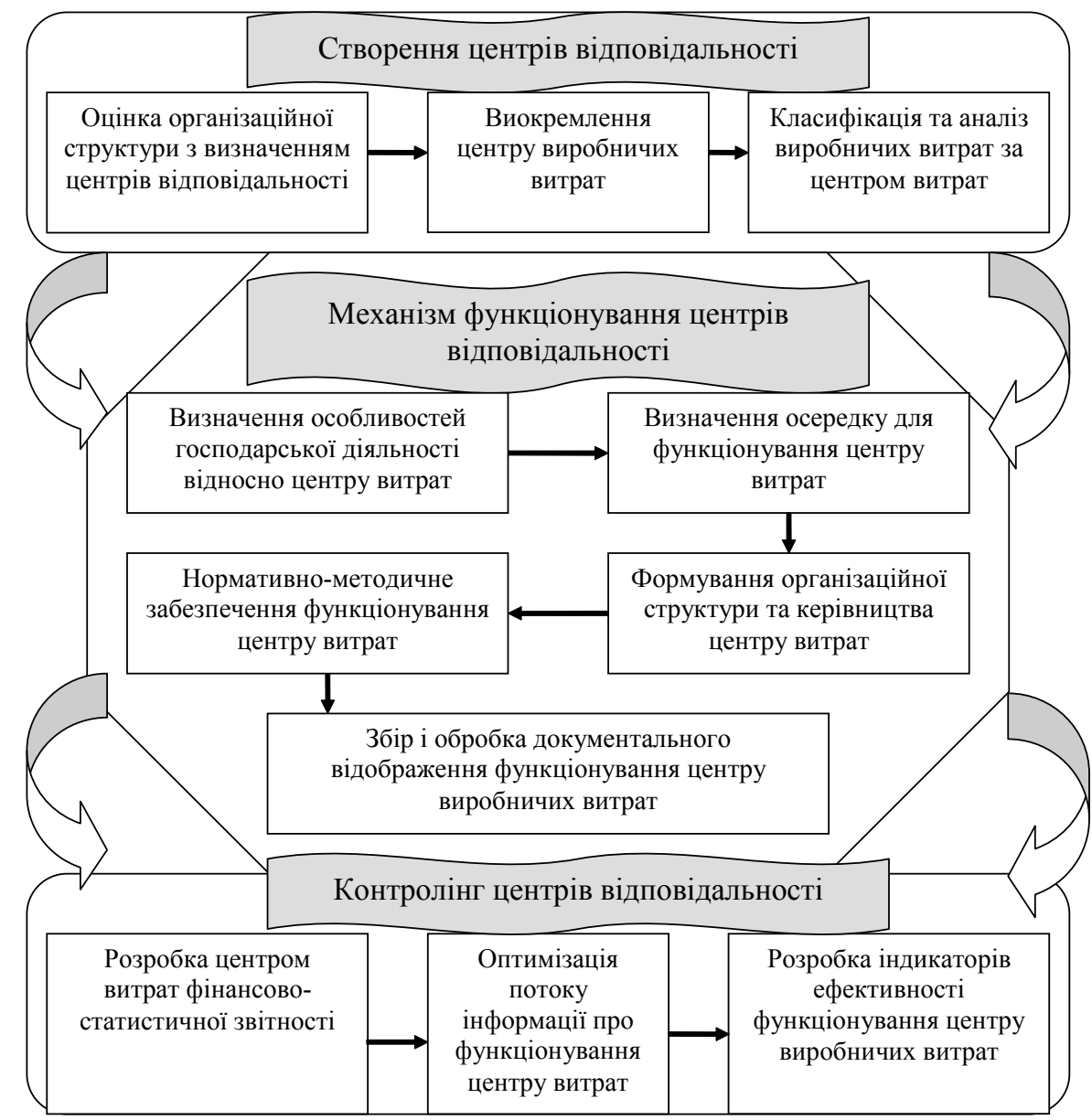

Рис. 3. Алгоритм формування системи управління виробничими витратами

Ажерело: [6; 9; 13].

ня процесу формування та переміщення потоку інформації, що у свою чергу зменшує ефективність прийнятих управлінських рішень [6].

Аецентралізація системи управління має поєднуватися із обов'язковим зазначенням рівня відповідальності керівників виробничих підрозділів та досягатися за рахунок:

- створення формальних процедур і нормативів витрат реагування на стан виробничих витрат при умовах без узгодження з найвищим рівнем управління;

- автоматизації управління підприємством, яка паралельно 3 контролем нормативів дає змогу прискорити рух інформаційного потоку, що у процесі управління витратами займає ключову позицію.

Ефективна та результативна діяльність системи управління виробничими витратами потребує забезпечення не лише якісною інформацією, а й оперативною Аля прийняття управлінських рішень.

Значна динамічність внутрішнього і зовнішнього середовища підприємства, широкий асортимент виробленої продукції, масштаби виконуваних робіт, особливості діяльності центру виробничих витрат зумовлює вагомі вимоги до терміну переміщення інформаційного потоку у системі управління витратами. Нині система управління вважається ефективною переважно при автоматизації формування і пересуванні потоків інформації у ній [7].

Перевагами застосування автоматизованого формування, збору та обробки інформації $€$ :

- отримання оперативної, повної та достовірної інформації про виробничу діяльність усіх центрів витрат;

- своєчасне формування звітної документації по центрах виробничих витрат;

- створення загального інформаційного поля на всіх стадіях руху інформації, що збільшує ефективність грошового потоку та контролю у системі управління;

- скорочення витрат часу та економія ресурсів на ведення оперативного обліку виробничих витрат; 
- оперативний облік технологічних операцій та процесів підприємства у комплексній інформаційній системі.

Збільшення ефективності управління виробничими витратами при автоматизації є очевидним заходом, однак проблемою залишається вибір правильних, результативних засобів автоматизації для підприємств.

\section{ВИСНОВКИ З ПРОВЕДЕНОГО ДОСЛІДЖЕННЯ I ПЕРСПЕКТИВИ ПОДАЛЬШИХ РОЗВІДОК У ЦЬОМУ НАПРЯМІ}

Таким чином, персонал повинен відповідати всім вимогам, що пред'являються до нього посадовими обов'язками, змістом та характером праці, а також вимогам, зумовленим ефективною організацією виробництва, використанням найбільш раціональних методів роботи, технічних засобів. Оцінюванню підлягають не лише потенційні можливості працівника, його професійна компетентність, але і реалізація цих можливостей у ході виконання доручених обов'язків, відповідність процесу виконання цієї роботи певній ідеальній моделі, конкретним умовам виробництва.

Зміни у господарській діяльності підприємства, незалежно від ефективності прийнятих рішень не будуть впроваджені у виробництво без відповідної мотивації персоналу підприємства. Одним із головних матеріальних стимулів продуктивності праці є їі оплата. Спонукальним мотивом високопродуктивної праці працівників $є$ необхідність задоволення особистих потреб.

Щодо управління виробничими витратами, то воно буде повністю ефективним при створенні комплексної системи управління витратами. Аля цього слід взяти до уваги вплив внутрішніх та зовнішніх факторів, врахувати специфіку існуючої системи управління та проаналізувати організаційну структуру підприємства. Незалежно від специфіки господарської діяльності порядок створення системи управління виробничими витратами має охоплювати низку етапів спрямованих на створення ефективних центрів відповідальності, формування результативних центрів витрат, забезпечення ефективної системи управління. У сучасних умовах ефективність управління виробничими витратами також має грунтується на застосуванні засобів автоматизації, формуванні обгрунтованого потоку інформації для прийняття управлінських рішень апаратом управління підприємством.

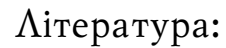

1. Вакуленко Ю.В., Олійник А.С., Гевленко O.Є. Системна характеристика управління конкурентоспроможністю підприємства. Агросвіт. 2018. № 18. C. $10-16$.

2. Гадзало А.Я. Значення інтелектуального потенціалу в умовах поглиблення євроінтеграційних процесів. Економіка АПК. 2006. № 8. C. $138-142$.

3. Макаренко П.М., Олійник А.С. Основні принципи управління витратами сільськогосподарського виробництва. Організаційно-економічний механізм реалізації стратегічних напрямів розвитку АПК: матеріали II Всеукраїнської науково-практичної інтернет-конференції за підсумками наукових досліджень. Вип. II. Мелітополь, ТАAУ, 2015. C. 4-6. URL: http:/ / nauka.tsatu.edu.ua/stud-nauka/oem-20142015.pdf\#page $=4$

4. Мізюк Б.М. Особливості стратегічного управління підприємствами. Фінанси України. 2002. № 12. C. $31-33$.

5. Цал-Цалко Ю.С. Витрати підприємства. Київ: ЦУ, 2002.656 с.

6. Олійник А.С. Економіко-структурна побудова витрат виробництва в аграрному середовищі. Управління розвитком суб'єктів підприємництва: механізми, реалії, перспективи / за заг. ред. Т.В. Гринько. Аніпро: Біла К.О., 2018. C. $230-239$.

7. Олійник А.С., Тургеля Ю.С., Соколовська Ю.Є. Виробничо-маркетингові стратегії антикризового управління. Інвестиції: практика та досвід. 2020. № 19-20. С. 110-116.

8. Олійник А.С., Піхуля О.Г., Романова О.В., Аопан А.М. Конкурентоспроможність персоналу як складова ефективної діяльності підприємства. Економіка та держава. 2020. № 1. C. $97-101$.

9. Олійник А.С., Терещенко I.О. та ін. Управління центрами витрат як інструмент ефективної підприємницької діяльності: монографія. Економічний, організаційний та правовий механізм підтримки і розвитку підприємництва. Полтава: ПААА , 2019. C. $152-159$.

10. Півнюк О. П. Фактори, що визначають обсяг та структуру витрат виробництва на підприємстві. 2010. URL: http://www.economyconfer.com.ua/full_article/624/

11. Посилкіна О. В. Управління персоналом: навч. посіб. Харків: НФаУ, 2015. 517 с.

12. Markina I., Oliinyk A. Effective cost management - a priority condition of agricultural enterprises development. "Modern Science - Modern veda", 2019. Vol. 5. P. 42-52. 
13. Oliinyk A.S. Formation of cost centers for efficient management of agrarian enterprises: monograph. Management of the 21st century: globalization challenges / in edition I. Markina. Prague: Nemoros s.r.o., 2018. 508 p.

14. Sazonova T., Oliinyk A., Oliinyk Ye. Staff development as an element of company's social security: monograph. Security management of the XXI century: national and geopolitical. Issue 2./ in edition I. Markina. Prague. Nemoros s.r.o. 2020. Czech Republic. 472 p. P. 441-446.

\section{References:}

1. Vakulenko, Yu.V. Oliinyk, A.S. and Gevlenko, A.Ye. (2018), "System characteristics of enterprise competitiveness management", Ahrosvit, vol. 18 , pp. $10-16$.

2. Gadzalo, A.Ya. (2006), "The value of intellectual potential in the conditions of deepening European integration processes", Ekonomika APK, vol. 8, pp. 138-142.

3. Makarenko, P.M. and Oliinyk, A.S. (2015), "Basic principles of cost management of agricultural production", Orhanizatsijno-ekonomichnyj mekhanizm realizatsii stratehichnykh napriamiv rozvytku APK [Organizational and economic mechanism of realization of strategic directions of agro-industrial complex development], II Vseukrains'ka naukovo-praktychna internet-konferentsiia za pidsumkamy naukovykh doslidzhen' [II All-Ukrainian scientific-practical Internet conference based on the results of scientific research], Tavriya State Agrarian University, Melitopol, Ukraine, pp. 4-6.

4. Mizyuk, B.M. (2002), "Features of strategic management of enterprises", Finance of Ukraine, vol. 12, pp. 31-33.

5. Tsal-Tsalko, Yu.S. (2002), Vytraty pidpryyemstva [Enterprise costs], TsUL, Kyiv, Ukraine.

6. Oliinyk, A.S. (2018), "Economic and structural construction of production costs in the agricultural environment", Upravlinnia rozvytkom sub'iektiv pidpryiemnytstva: mekhanizmy, realii, perspektyvy [Management of business development: mechanisms, realities, prospects], Dnipro, Ukraine.

7. Oliinyk, A.S. Turgelya, Yu.S. and Sokolovskaya, Yu.Ye. (2020), "Production and marketing strategies of crisis management", Investytsiyi: praktyka ta dosvid, vol 19-20, pp. 110-116.

8. Oliinyk, A.S. Pihulya, O.G. Romanova, O.V. and Lopan, A.M. (2020), "Competitiveness of personnel as a component of effective activity of the enterprise", Ekonomika ta derzhava, vol. 1, pp. 97-101.

9. Oliinyk, A.S., and Tereshchenko, I.O. (2019), "Cost center management as a tool for effective business", Ekonomichnyy, orhanizatsiynyy ta pravovyy mekhanizm pidtrymky i rozvytku pidpryyemnytstva, [Economic, organizational and legal mechanism of support and development of entrepreneurship], PSAA, Poltava, Ukraine.

10. Pivniuk, O.P. (2010), "Factors that determine the volume and structure of production costs at the enterprise", available at: http://www.economy-confer.com.ua/full_article/624/ (Accessed 16 March 2021).

11. Posylkina, O.V. (2015), Upravlinnya personalom, [Personnel management], NFaU, Kharkiv, Ukraine.

12. Markina, I. and Oliinyk, A. (2019), "Effective cost management - a priority condition of agricultural enterprises development", Modern Scienc, vol. 5, pp. 42-52.

13. Oliinyk, A.S. (2018), "Formation of cost centers for efficient management of agrarian enterprises", Menedzhment 21 stolittya: problemy hlobalizatsiyi, [Management of the 21st century: globalization challenges], Nemoros s.r.o., Prague, Czech Republic.

14. Sazonova, T. Oliinyk, A. and Oliinyk, Ye. (2020), "Staff development as an element of company's social security", Upravlinnya bezpekoyu XXI stolittya: natsional'ne ta heopolitychne, [Security management of the XXI century: national and geopolitical], Nemoros s.r.o., Prague, Czech Republic.

Стаття надійшла до редакиіӥ 12.04.2021 p.

www. dy.nayka.com.ua

Електронне фахове видання

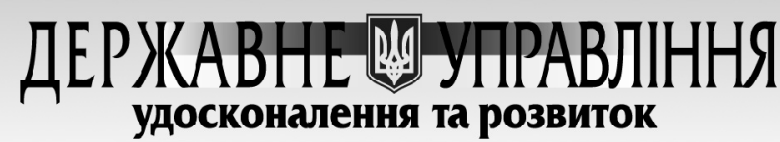

Виходить 12 разів на рік

включено до переліку наукових фахових видань України 3 ПитаНь ДЕРЖАВНОГО УПРАВЛІННЯ

(Категорія «Б»)

Наказ Міністерства освіти і науки України від 28.12.2019 №1643

Спеціальність 281

e-mail:economy_2008@ukr.net тел.: (044) 223-26-28, (044) 458-10-73 
Ю. Г. Неустроєв,

к. е. н., доцент кафедри економічної теорії та фінансово-економічної безпеки, ОАеська національна академія харчових технологій

ORCID ID: 0000-0002-1998-2564

DOI: $10.32702 / 2306-6792.2021 .7-8.103$

\title{
РОАЬ ІННОВАЦІЙ У ЗАБЕЗПЕЧЕННІ ЕКОНОМІЧНОЇ БЕЗПЕКИ
}

\author{
Y. Neustroiev, \\ $\mathrm{PhD}$ in Economics, Associate Professor of the Department of Economic Theory \\ and Financial and Economic Security, Odessa National Academy of Food Technologies
}

\section{THE ROLE OF INNOVATION IN ENSURING ECONOMIC SECURITY}

У статті досліджено роль інновацій у системі економічної безпеки на принципах системності, наукової неупередженості. СереА причин, що зумовлюють актуальність проблеми, автор навів тезу про те, що проблема інноваційного розвитку у рамках економічної безпеки має всебічний комплексний характер. Він також вказав, що таке положення обумовлено залежністю успіху інновацій віА великої кількості різноманітних факторів. Усю статтю підпорядковано такому принципу: економічна безпека будь-якої соціально-економічної системи спирається на наявний потенціал та його особливості. Обгрунтовано необхідність інноваційного розвитку економіки України задля підвищення рівня їі економічної безпеки. Було використано низку наукових методів: системний піАхіА, генетичний метоА, а також метод хронологічного порівняння економічних явищ. Описано різні моделі інноваційного розвитку.

Метою статті був аналіз місця інновацій у забезпеченні економічної безпеки України. Автор проаналізував науковий доробок, що існує у вітчизняній та зарубіжній науці. Розкрито сутність інновацій та їх вплив на економічну безпеку країни, а також зв'язок між інноваціями та конкурентноздатністю української продукції. Звернення до обраної теми пояснено з тієї позиції, що інновації створюють нові умови Аля економічного зростання. Нерідко їх виникнення супроводжується синергетичним ефектом інтеграційних процесів, котрий дозволяє скоординувати Аіяльність держави, корпорацій, окремих громадян та місцевих громаА. Тенденції розвитку світового співтовариства свідчать про зростаючий вплив інноваційної діяльності на темпи економічного прогресу.

На основі проведеного у статті аналізу зроблено висновок, що економіка України потерпає від відсутності інновацій, а це в свою чергу знижує рівень економічної безпеки країни. Впровадження різноманітних інновацій на основі відповідної інноваційної стратегії розвитку може змінити ситуацію на краще, підвищити темпи зростання економіки країни та життєвого рівня населення. Водночас деякі інновації, що імплементуються в окремі технологічні процеси промислового виробництва та інші галузі можуть мати негативний екологічний ефект, а також нести додаткові загрози, пов'язані з можливістю відмови технологічних вуздів. Це може призводити до техногенних катастроф і знижувати економічну безпеку країни. Найбільш продуктивною автору уявляється стратегія раціонального прораховування ризиків, свідомого закладення достатньої міцності в інноваційні технологічні структури.

The article investigates the role of innovations in the system of economic security on the principles of systematization, scientific impartiality. Among the reasons that determine the urgency of the problem, the author argued that the problem of innovative development in the framework of economic security is comprehensive. He also pointed out that this situation is due to the dependence of the success of innovation on a large number of different factors. In the whole article the subject is following principle: the economic security of any socio-economic system is based on the available potential and its features. The necessity of innovative development of Ukraine's economy in order to increase the level of its economic security is substantiated. A number of scientific methods were used: a system approach, a genetic method, and a method of chronological comparison of economic phenomena. Various models of innovative development are described.

The purpose of this article was to analyze the place of innovation in ensuring the economic security of Ukraine. The author analyzed the scientific achievements that exist in Ukrainian and foreign science. The essence of innovations and their impact on the economic security of the country are revealed. The appeal to the chosen topic is explained from the point of view that innovations create new conditions for economic growth. Often their emergence is accompanied by a synergistic effect of integration processes, which allows to coordinate the activities of the state, corporations, individual citizens and local communities. Trends in the development of the world community indicate the growing impact of innovation on the pace of economic progress. 
Based on the analysis conducted in the article, it is concluded that Ukraine's economy suffers from a lack of innovations, which reduces the level of economic security of the country. The implementation of various innovations on the basis of an appropriate innovative development strategy can change the situation for the better. At the same time, some innovations implemented in certain technological processes of industrial production and other industries may have a negative environmental impact. This can lead to man-made disasters and reduce the country's economic security. The most strategy is a rational calculation of risks, conscious laying of sufficient strength in innovative technological structures.

Ключові слова: економічної безпека, держава, управління економікою, інновачії.

Key words: economic security, state, economic management, innovations.

\section{ПОСТАНОВКА ПРОБЛЕМИ У ЗАГАЛЬНОМУ виглядІ}

У сучасний період особливо актуальним стає завдання підвищення рівня економічної безпеки України за рахунок активізації впровадження інновацій. Всередині країни збільшується економічна диференціація регіонів та населення. Структура економіки формується за рахунок домінування розвитку сировинних галузей. Це доводить необхідність модернізації системи економічної безпеки, успіх котрої може бути забезпечений на основі впровадження інновацій. Аобре відомо, що інноваційні процеси активізуються там, де виникають інновації, тобто можливості виробництва нового продукту у результаті науково-дослідницької роботи, ії матеріалізації через конструкторські розробки, а потім введення у масове виробництво, застосування у сфері споживання товарів та послуг. Генезис інновації виступає результатом об'єктивних процесів розвитку та розповсюдження нових знань в усіх сферах буття людської діяльності. Справа в тому, що розвиток науки багато в чому детермінує розвиток матеріального виробництва. Інновації створюють нові умови для економічного зростання, нерідко їх виникнення супроводжується синергетичним ефектом інтеграційних процесів, котрий дозволяє скоординувати діяльність держави, крупних корпорацій, окремих громадян та місцевих громад.

Українське суспільство на протязі багатьох років знаходиться у стані радикальних трансформацій економічної системи. Вони пов'язані 3 укріпленням та розвитком ринкового типу господарювання. Однією з паралельних тенденцій розвитку сучасної економіки виступає стрімка глобалізація. Ї̈̈ вплив на функціонування української господарської системи є досить суперечливим. Вона одночасно створює стимули для зростання економіки країни і підвищує ризики, пов'язані з міжнародним поділом праці. Аослідження проблем інноваційного розвитку у рамках економічної безпеки має всебічний комплексний характер, що обумовлює залежність успіху інновацій від великої кількості різноманітних факторів. Економічна безпека будь-якої соціально-економічної системи спирається на наявний потенціал та його специфіку. Одночасно вона не може бути реалізована поза взаємодією з іншими економічними системами. Інноваційний розвиток економіки збільшує можливість виживання економічної системи, їі стійкість, адаптивність до зовнішніх та внутрішніх загроз. Важливим завданням інноваційного розвитку $€$ нарощування здатності підтримувати високий рівень економічної безпеки. Ця теза означає, що є необхідність використання усіх наявних можливостей для забезпечення великої кількості інновацій та їх гідного рівня.

Основним завданням функціонування економічних систем $€$ забезпечення постійного економічного зростання та підвищення рівня добробуту їх членів. Ми можемо спостерігати, що вектор сучасного розвитку економіки багатьох країн все більше зміщується у напрямі інноваційної моделі функціонування господарства. Така модель передбачає широке використання інтелектуального ресурсу нації. Практично всюди у економічно просунутих країнах відмічається швидке збільшення чисельності та підвищення суспільної значимості так званого креативного класу. Це прошарок інтелектуальної еліти, котра разом з вітчизняним бізнесом використовує інновації для примноження капіталу, а в кінцевому рахунку, і збагачення країни.

Швидкий науково-технічний прогрес 3 кінця XX ст. перетворився у головний фактор забезпечення стійкого розвитку, так як він підвищив динамізм соціально-економічних систем господарюючих суб'єктів. У багатьох країнах інновації допомогли укріпити економічну безпеку держави. Це не дивно, бо саме інноваційна діяльність виступає ефективним інструментом досягнення високого рівня конкурентоздатності країни, слугує базисом для розвит- 
ку інноваційного типу економічного зростання. Аля успішного протікання процесу модернізації необхідно розвивати ринок інновацій, який забезпечує виникнення в економічній системі критичної маси стимулів до провадження нових ідей та технологій. Цей ринок, підприємництво та ефективна державна підтримка є елементами стабільного економічного зростання і укріплення економічної безпеки.

\section{ОГЛЯД НАУКОВОЇ ЛІТЕРАТУРИ}

У західних країнах питання взаємовпливу інновацій та економічної безпеки привернули увагу багатьох дослідників. Серед них можна назвати Б. Твисса, А. Тідда, Р. Фостера, В. Хіпеля, И. Шумпетера, $\Lambda$. Соеті, Е. Жуста, Аж. Брогеля, А. Сієрера, М. Поджолу, В. Аейла, С.Ажоншера.

Провідними вітчизняними дослідниками у вивченні питань інноваційної економіки та укріплення економічної безпеки є: О. Амоша, М. Аолішній, С. Онишко, Т. Паєнтко, А. Кузн-

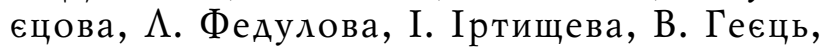
С. Глазьєв, Б. Кваснюк, Н. Краснокутська, М. Крупка, О. Мапко, Б. Малицький, Ю. Ніколенко, С. Онишко, В. Осецький, С. Пирожков, В. Семиноженко, В. Александрова, К. Багріновський, Ю. Бажал, О. Аанільян, В. Гурковський, О. Аитвиненко, О. Азьобань, М. Панов, А. Харченко, Е. Аевченко, П. Мартін, А. Акісті.

Вітчизняний дослідник В. Вишневська детально проаналізувала розвиток інновацій в Україні. Вона дійшла висновку, що на поступ наукової сфери негативним чином вплинула некомпетентна державна політика проведення ринкових реформ, зокрема, приватизація, трансформація бюджетної, податкової, кредитної систем. Фактично, цей процес розгортався без врахування науково-технологічного фактору та його впливу на ефективність, конкурентоспроможність вітчизняної економіки. Безперспективна політика виживання, яка була взята на озброєння українською політичною елітою, стала глухим кутом для науково-технічного розвитку і спричинила замість його оновлення та якісного поліпшення деградацію. На думку дослідниці, інноваційні процеси в українській економіці не набули вагомих масштабів. Кількість підприємств, що впроваджують інновації, зменшується 3 кожним роком. На сьогоднішній день їх кількість складає всього лише 12-14\%, що менше у 3-4 рази, ніж у країнах з інноваційно розвиненими економіками. Низький рівень наукоємності вітчизняного виробництва визначається не тільки дефіцитом коштів, а й структурою економіки. У ній домінують низькотехнологічні галузі виробництва, котрі належать до малонаукоємних галузей: добувна і паливна, харчова, легка промисловість та агропромисловість [1, с. 186-187].

В. Мельник та Г. Погріщук вказали, що поняттям "інновації" не слід розуміти лише нові технології чи застосування нової техніки. Вони $€$ значним джерелом економічного прогресу, бо спрямовані на досягнення економічного, соціального та інших видів ефектів. Інновації здатні підвищити ефективність функціонування економічної системи, а їх впровадження охоплює різні сфери діяльності соціально-економічних структур. Інноваційний процес слід розглядати у ракурсі невизначеності результату інновацій, що звичайно зумовлює певний ризик інноваційної діяльності. Аише $20 \%$ наукових винаходів стають інноваціями. На сьогодні відомі різні моделі інноваційного розвитку: лінійна, лінійно-послідовна, інтерактивна, інтегрована, мережево-когнітивна. Інноваційна модель розвитку, на думку авторів, - це таке вираження інноваційних пріоритетів напрямку економічного розвитку та управлінських структур, яке спрямоване на формування модернізованого типу розширеного відтворення національної економіки. Водночас інноваційний процес об'єктивно зберігає свою етапність, тобто є етап спаду, на якому будь-яка інновація втрачає свою новизну [2, с. 202-203].

К. Бойко охарактеризував інноваційний розвиток як процес створення, впровадження та комерціалізації інновацій. Вони, на його думку, забезпечують якісні зміни об'єкта керування, соціально-економічний, екологічний ефект, а також зростання прибутків суб'єктів інноваційного розвитку. Крім цього, дослідник відмітив підвищення інвестиційної привабливості підприємств, котрі запроваджують новації у довгостроковій перспективі. Економічна новація охоплює всі види діяльності разом з науковими дослідженнями, розробкою та впровадженням винаходів. Успішність інновацій зумовлена об'ємом фінансових витрат на проведення досліджень та реалізації їх результатів, масштабністю нововведень. Аослідник виділив три головні типи моделей інноваційного розвитку. Ао першої належать країни, які є лідерами в наукових дослідженнях (США Великобританія, Франція). Ао Аругої - країни, що стимулюють економічні структури задя поширення нововведень шляхом створення сприятливого науково-технічного середовища (Німеччина, Швеція, Швейцарія). Ао третього типу моделей інноваційного розвитку він зарахував країни, 
котрі створюють інноваційної структуру, яка забезпечує сприйнятливість досягнень науково-технічного прогресу (Японія, Південна Корея) $[3$, с. 15].

\section{META CTATTI}

Метою статті є розкриття ролі інновацій у забезпеченні економічної безпеки України.

\section{ВИКЛАД ОСНОВНОГО МАТЕРІАЛУ}

Інновації виступають важливими індикаторами рівня економічного зростання, ї продуктивність грунтується на тому, що знання та науково-технічний прогрес перетворились у сучасному світі на основні фактори розвитку економіки. Такому процесу сприяє адаптування стратегій інноваційного розвитку, особливостей певної країни. Інноваційний розвиток дозволяє вибудувати модернізовану інфраструктуру постіндустріального суспільства. Це уявляється важливим завданням у рамках підвищення економічної безпеки країни, оскільки вона є джерелом отримання серйозних конкурентних переваг у системі координат глобальної економіки. Водночас необхідно відмітити, що глобалізація значно впливає на процес впровадження інновацій та побудову інноваційного механізму. Вона привносить ряд можливостей для диверсифікації економіки [4, с. 180].

Вибір інноваційної продукції має здійснюватись на основі певних критеріїв. Серед них слід виділити орієнтацію на потреби людини як кінцевого споживача. Крім цього, слід наголосити на важливості для розвитку економіки України, значущості на ринку у світовому масштабі. Побудова ринку інноваційних продуктів у формі мережі, у якій посередницькі структури замінені на вузли з високотехнологічними інформаційними рішеннями є досить перспективною. Однак для формування ринку інновацій необхідно підтримувати на відповідному рівні науково-технічний потенціал та соціальне підприємництво [5, с. 30-31].

Очевидно, що інноваційна діяльність є особливого роду підприємництвом, яке спрямоване на використання наукових знань. Їх можна використати для одержання прибутку. Розповсюдженню подібної діяльності у значній мірі сприяє політика держави, котра має базуватися на створенні сприятливого інвестиційного клімату. Окрім цього, позитивним фактором для впровадження інновацій є наявність ефективного механізму взаємодії між бізнесом та науковими структурами. Впровадження інновацій сприяє підвищенню ступеня адаптивності економічних структур до умов зовнішнього се- редовища, створює базис для сталого розвитку та довгострокової стабільності [6, с. 250].

В. Кравченко виділив декілька груп загроз, котрі виникають у рамках інноваційної діяльності. Ао першої групи він відносить ті, що пов'язані із забезпеченням інноваційної діяльності, тобто загрози незабезпечення інноваційного проекту достатнім рівнем фінансування, необхідним рівнем кадрового та технологічного забезпечення. Ао другої групи потрапили загрози, що виникають у процесі організації інноваційної діяльності, наприклад, забруднення довкілля, неправильний вибір ринків збуту. Повністю уникнути загроз інноваційної діяльності неможливо, бо, на думку вченого, інновації та ризик це дві взаємопов'язані категорії. Будь-яке підприємство чи організаційна структура функціонує у досить складному середовищі, котре потребує постійної роботи над удосконаленням управлінських рішень, активізації діяльності щодо гарантування економічної безпеки даного господарського об'єАнання [7, с. 30-31].

Ефективним методом зниження ризиків інноваційної діяльності виступає страхування. За його допомогою підприємство мінімізує майже всі майнові і навіть деякі політичні, кредитні, комерційні та виробничі ризики. Проте цей вид мінімізації ризиків має низку обмежень. Передусім це досить високий розмір страхового внеску. Інноваційна складова економічної безпеки виступає системою заходів безпеки, яка покликана забезпечити широке використання інноваційних нововведень та створити сприятливий інвестиційний клімат для виробництва [8, с. 175-176].

Питома вага реалізованої інноваційної продукції в загальному обсязі промислової продукції у період з 2001-2010 рр. знизилася на $44 \%$. Водночас рівень інноваційної безпеки Україні характеризується й іншими показниками. Серед іншого станом науково-технічної бази та науково-дослідних інститутів, а також станом вищої наукової освіти, показниками впровадження інновацій на підприємствах, впровадження нових технологічних процесів, патентування ресурсозберігаючих технологій. Модель інноваційного процесу, на думку О. Кириченко, має обов'язково включати у себе фундаментальні дослідження, розробку та проектування, промислове виробництво, маркетинг та збут інноваційного продукту[9, с. 175-176].

Американські експерти Г. Макада та Ф. Квадво висловили думку, що потужним джерелом інновацій виступають цифрові технології, котрі стали популярними внаслідок економічного 
зростання глобальної економіки, міжнародної конкурентоспроможності та одночасного підвищення загроз національної безпеки. На думку вчених, цифрова економіка має досить глибокий вплив на світову траєкторію підвищення суспільного добробуту пересічних громадян. ІТ-технології впливають практично на все, що відбувається зараз у світі: від розподілу ресурсів до розподілу та зростання доходів. Водночас вчені вказали на те, що виміряти внесок інформаційних технологій у зростання та відповідні соціальні показники досить складно. Вони відзначили мінливість економічної кон'юнктури на ринку товарів та послуг. Результати багатьох досліджень вказують на те, що обсяг цифрової економіки може бути оцінений як 11 трильйонів доларів, що еквівалентно приблизно $15 \%$ світового ВВП [12].

\section{ВИСНОВКИ}

Спробуємо підсумувати вищевикладене у формі висновків. Слід вказати, що цілком очевидно, що економіка України задихається в умовах відсутності серйозних інвестицій, а запровадження різноманітних інновацій може підвищити темпи зростання економіки країни та життєвого рівня населення. Таким чином, можна сказати, що інновації є ефективним інструментом підтримання економічної безпеки країни. Вони є могутнім фактором зростання конкурентноздатності країни. Впровадження інновацій запускає процес розвитку соціально-відповідального бізнесу, процвітання окремих підприємств, компаній, територіальних громад та національної економіки в цілому. Світова практика доводить що інновації займають провідне місце в економіці розвинутих країн. Водночас деякі інновації, що впроваджуються в окремі технологічні процеси промислового виробництва можуть мати негативний екологічний ефект. У рамках економічної безпеки країни постає завдання прорахувати усі можливі ризики та забезпечити необхідну міцність технологічних структур, справедливо оцінити вплив інновацій на оточуюче середовище.

Інноваційний процес слід розглядати як зміну загальноприйнятих технологічних параметрів економічних моделей з метою отримання позитивного економічного ефекту, підвищення прибутків. 3 огляду на це визначення, можна стверджувати, що інновації є важелем укріплення економічної безпеки країни. Тенденції розвитку світового співтовариства свідчать про зростаючий вплив інноваційної діяльності на темпи економічного зростання.
Треба зауважити, що забезпечення інноваційного розвитку можливе лише на базі розробки інноваційної стратегї̈, котра буде включати в себе кроки, направлені на стимулювання розвитку різних напрямків технологічного прогресу, а також інноваційну політику та оцінку ефективності інновацій.

Суб'єкти інноваційної діяльності прагнучи до підвищення своїх прибутків поступово отримують необхідний досвід для ефективного аудиту інновацій, максимізації позитивного ефекту від них та мінімізації помилок. Низька інвестиційна активність украӥнських підприємств призводить до зниження конкурентноздатності вітчизняної економіки, що є великою перешкодою для інноваційного розвитку. Найбільш вагомий ефект організації та забезпечення випуску інноваційної високотехнологічної продукції може мати синтез технологій у поєднанні $з$ прискореним розвитком науки. Аержавне регулювання інноваційної діяльності та державна підтримка інноваційних програм також уявляється необхідним інструментом для прискорення інноваційного розвитку. Створення нових технологій не гарантує автоматичного досягнення економічного успіху, бо необхідно трансформувати нові технології таким чином, щоб отримати продуктивні технологічні процеси та інноваційну продукцію.

\section{\ітература:}

1. Вишнівська Б.В. Інноваційний розвиток України [Електронний ресурс]/ Б.В. Вишнівська // Науковий вісник Національного університету біоресурсів і природокористування України. Серія: Економіка, аграрний менеджмент, бізнес. - 2016. - Вип. 244. - С. 183-191.

2. Мельник B.I., Погріщук Г.Б., Погріщук О.Б. Інноваційні зміни в економіці в контексті еволюційних зрушень / B.І. Мельник, Г.Б. Погріщук, О.Б. Погріщук // Науковий вісник Ужгородського університету: серія: Економіка; збірник наукових праць / редкол.: В.П. Мікловда, В.І. Ярема та ін. - Ужгород: Вид-во УжНУ "Говерла", 2016. - Вип. 2 (48). - С. 200-207.

3. Бойко К.К. Теоретичні основи механізму інноваційного розвитку підприємств регіону / К.К. Бойко // Вісник соціально-економічних досліджень. - 2013. - Вип. 2 (1). - С. 14-18.

4. Морозова С.А. Інноваційний розвиток світової економіки: теоретичний аспект / С.А. Морозова // Вісник Приазовського державного технічного університету: зб. наукових праць / ПАТУ. - Маріуполь, 2016. - Вип. 32, T. 1. - C. $179-186$. 
5. Бутенко A.I. Методичні підходи до формування організаційного забезпечення ефективного використання інноваційного потенціалу технологічного підприємництва / А.І. Бутенко, Н.А. Шлафман, О. В. Бондаренко // Економічні інновації. - 2018. - Вип. 67. - С. 22-36.

6. Квасницька Р.С., Ардашкіна Н.С. Особливості інноваційної діяльності підприємств у сучасних умовах / Р.С. Квасницька, Н.С. Ардашкіна // Вісник Хмельницького національного університету. Економічні науки. — 2009. № 6, T. 3. - C. 247-251.

7. Кравченко В.О. Інноваційний розвиток як основа економічної безпеки підприємства / B.О. Кравченко // Науковий вісник. Одеський національний економічний університет. Всеукраїнська асоціація молодих науковців. - Науки: економіка, політологія, історія. - 2013. № 26 (205). - С. 122-131.

8. Аьяченко О.А. Економічна безпека інноваційно-орієнтованих підприємств в умовах євроінтеграції/ О.А.Аьяченко, А.П. Артеменко // Економічний вісник Національного технічного університету України "Київський політехнічний інститут". - 2015. - № 12 . C. $173-180$.

9. Кириченко О.С. Інноваційна безпека як невід'ємна складова економічної безпеки та ефективного проектно-орієнтованого розвитку сучасних підприємств / О.С. Кириченко // Фін.-кредит. діяльн.: пробл. теорії та практики: зб. наук. пр. - 2012. - Вип. 1, Т. 1. - С. 94-99.

10. Makada H.-N., Kwadwo F. Trends in the information technology sector. - Режим доступу: https://www.brookings.edu/research/trendsin-the-information-technology-sector/ (Аата звернення: 30.03.2021 року).

\section{References:}

1. Vyshnivska, B. V. (2016), "Innovative development of Ukraine", Naukovyi visnyk Natsionalnoho universytetu bioresursiv i pryrodokorystuvannia Ukrainy, vol. 244, pp. 183-191.

2. Melnyk, V. I. Pohrishchuk, H. B. and Pohrishchuk, O. B. (2016), "Innovative changes in the economy in the context of evolutionary changes", Naukovyi visnyk Uzhhorodskoho universytetu: seriia: Ekonomika; zbirnyk naukovykh prats, vol. 2 (48), pp. 200-207.

3. Bojko, K. K. (2013), "Theoretical bases of the mechanism of innovative development of the enterprises of the region", Visnyk sotsialno-ekonomichnykh doslidzhen, vol. 2 (1), pp. 14-18.

4. Morozova, S. A. (2016), "Innovative development of the world economy: theoretical aspect", Visnyk Pryazovskoho derzhavnoho tekhnichnoho universytetu: zb. naukovykh prats, vol. 32 (1), pp. 179-186.

5. Butenko, A. I. (2018), "Methodical approaches to the formation of organizational support for the effective use of the innovative potential of technological entrepreneurship", Ekonomichni innovatsii, vol. 67, pp. 22-36.

6. Kvasnytska, R. S. and Ardashkina, N. S. (2009), "Features of innovative activity of enterprises in modern conditions", Visnyk Khmelnytskoho natsionalnoho universytetu. Ekonomichni nauky, vol. 6 (3), pp. 247-251.

7. Kravchenko, V. O. (2013), "Innovative development as a basis of economic security of the enterprise", Naukovyi visnyk. Odeskyi natsionalnyi ekonomichnyi universytet. Vseukrainska asotsiatsiia molodykh naukovtsiv, vol. 26 (205), pp. 122-131.

8. Diachenko, O. A. (2015), "Economic security of innovation-oriented enterprises in the context of European integration", Ekonomichnyi visnyk Natsionalnoho tekhnichnoho universytetu Ukrainy "Kyivskyi politekhnichnyi instytut", vol. 12, pp. 173-180.

9. Kyrychenko, O. S. (2012), "Innovative security as an integral part of economic security and effective project-oriented development of modern enterprises", Fin.-kredyt. diialn.: probl. teorii ta praktyky: zb. nauk. pr., vol. 1 (1), pp. 94-99.

10. Makada, H.-N. and Kwadwo, F. (2021), "Trends in the information technology sector",The official site of the Brookings Institution, available at: https://www.brookings.edu/research/trendsin-the-information-technology-sector/ (Accessed 17 April 2021).

Стаття надійшла до редакиї 19.04.2021 p.

www. economy.nayka.com.ua

Електронне фахове видання

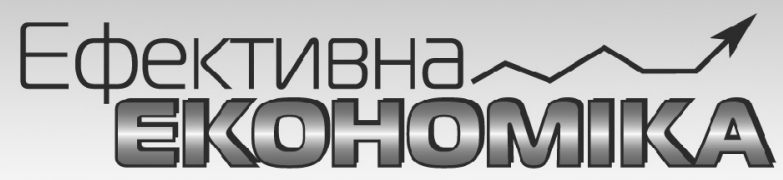

\section{Виходить 12 разів на рік}

Журнал включено до переліку наукових фахових видань України з ЕКОНОМІЧНИХ НАУК (Категорія “Б»)

Спеціальності - 051, 071, 072, 073, 075, 076, 292

e-mail:economy_2008@ukr.net тел.: (044) 223-26-28

(044) 458-10-73 


\title{
Н. О. Аверчева,
}

к. е. н., Аоцент, в. о. завідувача кафедри загальноекономічної підготовки, Херсонський державний аграрно-економічний університет

ORCID ID: 0000-0003-4534-639X

DOI: $10.32702 / 2306-6792.2021 .7-8.109$

\section{ЕКОНОМІЧНИЙ АНАЛІЗ РЕНТАБЕАЬНОСТІ MONOKA}

\author{
N. Avercheva, \\ $\mathrm{PhD}$ in Economics, Associate Professor, Head of the Department of General Economic Training, \\ Kherson State Agrarian and Economic University
}

\section{ECONOMIC ANALYSIS OF MILK PROFITABILITY}

Аосліджено проблеми формування рівня рентабельності молока за категоріями сільськогосподарських виробників. Визначено, що сучасна ситуація на ринку молока відзначається суттєвими ризиками щодо зниження прибутковості молочного бізнесу. На рентабельність молока негативно впливають процеси зростання цін на сировинні ресурси, нівелювати які можливо на основі приросту продуктивності корів. Порівняльний аналіз рівня ціни на молоко-сировину у підприємствах і господарствах населення дозволив виявити тенденцію до збільшення розриву і зниження цінових конкурентних позицій господарств населення. Встановлено, що цінову перевагу має категорія великих виробників з потужністю вище 4 тис. т молока за рік. ПіА час проведення факторного аналізу прибутковості виробництва молока виявлено вищі темпи зростання витрат, порівняно 3 підвищенням доходів. Обгрунтовано практичні заходи щодо оптимізації виробничих витрат та підвищення ефективності використання ресурсів у молочному скотарстві.

Peculiarities and problems of forming the level of milk profitability by categories of agricultural producers are studied. It is established that the profitability of milk production in enterprises has a positive dynamics, but the current situation in the milk market is marked by significant risks to reduce the profitability of the dairy business. The profitability of milk is negatively affected by the processes of rising prices for raw materials feed, energy, veterinary, technical and technological, it is possible to level them on the basis of increasing productivity of cows and the use of internal factors of enterprises. A comparative analysis of the price level of raw milk in enterprises and households revealed a tendency to increase the gap and reduce the price competitive position of households. The distribution of enterprises by average sales prices shows that the category of large producers with a capacity of more than 4 thousand tons of milk per year has a price advantage. When conducting a factor analysis of the profitability of milk production in one of the largest enterprises in the Kherson region an increase in costs at a higher rate compared to the increase in sales revenues is found. Practical measures to optimize production costs and increase the efficiency of resource use in dairy farming are substantiated. It is determined that additional investment in the development of dairy farming is impractical and requires increased control over costs and production resources in agricultural enterprises. The search for reserves to increase the profitability of the dairy industry should focus on optimizing the cost of production and sale of milk, overhead and administrative costs. The increase in milk production and sales due to the increase in the number of cows and their productivity guarantees an increase in income; increase in the sale price is provided by improving the quality of milk and bringing it to the appropriate condition, introduction of new sales channels, establishment of mutually 
beneficial contractual relations with processing enterprises. Marketing activities of milk producers should be aimed at determining the level of prices, competition, finding partners and processing companies, creating a logistics system for marketing products.

Ключові слова: рентабельність, прибуток, иіноутворення, собівартість, виробничтво молока, аналіз факторів.

Key words: profitability, profit, pricing, cost, milk production, factor analysis.

\section{ПОСТАНОВКА ПРОБЛЕМИ}

Галузь скотарства в Україні тривалий час знаходиться в кризовому стані - поголів'я і обсяги виробництва постійно скорочуються, змінюється структура виробництва на користь господарств населення, розбалансовуються зв'язки у системі "виробники - переробні підприємства". Крім того, на ринку молока і молочної продукції посилюється тиск з боку імпортної продукції, що загрожує національним виробникам і переробним підприємствам конкуренцією та впливом на цінову ситуацію. При спаді обсягів виробництва за період 20002019 рр. імпортні постачання молочних продуктів в Україну зросли у 6,7 разів - від 50 до 337 тис. т у перерахунку на молоко [1].

Умови зовнішнього і внутрішнього ринку прямо впливають на діяльність підприємств-виробників молока-сировини та переробних підприємств. У сучасних умовах інтеграції національної економіки до системи світових та європейських зовнішньоекономічних зв'язків, проблема ефективного розвитку галузі молочного скотарства $є$ актуальною, оскільки постає необхідність забезпечення конкурентоспроможності вітчизняної продукції як на внутрішньому, так і на зовнішніх ринках. Ця проблема обумовила актуальність і вибір теми дослідження, адже проведення економічного аналізу рентабельності виробництва молока виступає основою прийняття управлінських рішень та визначення внутрішньогосподарських резервів її підвищення.

Метою дослідження $є$ визначення напрямів підвищення рентабельності галузі молочного скотарства на основі економічного аналізу основних чинників виробництва.

\section{АНАЛІЗ ОСТАННІХ ДОСЛІДЖЕНЬ І ПУБЛІКАЦІЙ}

Причини низьких показників ефективності галузі у наукових колах вивчають з точки зору різних аспектів. О. Петриченко проводить порівняльний аналіз закупівельної ціни на вироблене в сільськогосподарських підприємствах молоко та повної собівартості, відзначає вплив рівня товарності продукції на рівень закупі- вельних цін, виручки від реалізації та ефективність виробництва в цілому. Зростання ефективності виробництва молока обумовлюється підвищенням рівня концентрації, спеціалізації та інтенсифікації його виробництва, а маса прибутку виступає засобом сприяння розвитку молочної галузі [2, с. 62-72].

M.M. Ільчук, I.А. Коновал вважають, що основними причинами зменшення обсягів виробництва продукції скотарства в Україні є: падіння попиту на її продукцію на внутрішньому ринку через зниження купівельної спроможності населення; втрата частини та неможливість швидкої переорієнтації на нові зовнішні ринки молока й молочної продукції внаслідок низької якості її сировини; висока, порівняно 3 іншими галузями сільського господарства, капіталомісткість та тривалий термін окупності інвестицій, які потребує галузь для ії відродження [3, с. 51-59].

О.М. Супрун, Є.I. Величко, I.С. Іваннікова досліджують необхідність цінового і фіскального стимулювання розвитку галузі та наголошують на негативному впливі на розвиток галузі безсистемних законодавчих змін [4, с. 64-67].

T.I. Яворська, $\Lambda$.А. Загнітко вивчають ситуацію розвитку галузі з урахуванням регіональних особливостей господарювання, впливу вартісних факторів (виробнича собівартість, повна собівартість, ціна реалізації) на формування ефективності виробництва молока, розрахунку їхніх прогнозних параметрів [5, с. 53-59].

Отже, питання ефективного розвитку молокопродуктового підкомплексу постійно перебувають під пильною увагою наукових досліджень. Проте не повною мірою висвітлено питання економічного аналізу рентабельності продукції на рівні регіонів і господарюючих суб'єктів, визначення основних чинників прибутковості виробництва, впливу собівартості і ціни реалізації на формування фінансових результатів виробництва і реалізації молока.

\section{ФОРМУЛЮВАННЯ ЦІЛЕЙ СТАТТІ}

Підвищення рентабельності виробництва молока є складним процесом на рівні кожного 
АГРОС ВIT № $7-8,2021$

Таблиця 1. Виробництво молока за категоріями господарств в Україні, тис. т

\begin{tabular}{|c|c|c|c|c|c|c|c|c|c|}
\hline \multirow{2}{*}{$\begin{array}{c}\text { Категорії } \\
\text { господарств }\end{array}$} & \multicolumn{8}{|c|}{ Роки } & \multirow{2}{*}{$\begin{array}{c}2019 \text { p. y } \\
\text { \% до } \\
2000 \text { p. }\end{array}$} \\
\hline & 2000 & 2005 & 2010 & 2015 & 2016 & 2017 & 2018 & 2019 & \\
\hline $\begin{array}{l}\text { Всі категорії } \\
\text { господарств }\end{array}$ & 12657,9 & 13714,4 & 11248,5 & 10615,4 & 10381,5 & 10280,5 & 10064,0 & 9663,2 & 76,3 \\
\hline Підприємства & 3668,7 & 2582,5 & 2216,6 & 2669,2 & 2705,6 & 2765,7 & 2755,5 & 2728,6 & 74,4 \\
\hline $\begin{array}{l}\text { У т. ч. } \\
\text { фермерські } \\
\text { господарства }\end{array}$ & 67,8 & 96,3 & 112,1 & 177,4 & 183,6 & 194,8 & 201,8 & 209,2 & 308,6 \\
\hline $\begin{array}{l}\text { Господарства } \\
\text { населення }\end{array}$ & 8989,2 & 11131,9 & 9031,9 & 7946,2 & 7675,9 & 7514,8 & 7308,5 & 6934,6 & 77,1 \\
\hline \multicolumn{10}{|c|}{ Структура виробництва, \% } \\
\hline Підприємства & 29,0 & 18,8 & 19,7 & 25,1 & 26,1 & 26,9 & 27,4 & 28,2 & $-0,8$ в. П. \\
\hline $\begin{array}{l}\text { У т. ч. } \\
\text { фермерські } \\
\text { господарства }\end{array}$ & 0,5 & 0,7 & 1,0 & 1,7 & 1,8 & 1,9 & 2,0 & 2,2 & +1,7 в. п. \\
\hline $\begin{array}{l}\text { Господарства } \\
\text { населення }\end{array}$ & 71,0 & 81,2 & 80,3 & 74,9 & 73,9 & 73,1 & 72,6 & 71,8 & $+0,8$ в. п. \\
\hline
\end{tabular}

підприємства, який залежить від внутрішніх і зовнішніх чинників та потребує удосконалення управління на основі системного підходу. Аля побудови ефективної системи управління рентабельністю продукції потрібно виявити та проаналізувати основні фактори, їх взаємозв'язок і взаємодію у процесі виробництва і реалізації продукції.

\section{META CTATTI}

Мета статті - оцінка поточної ситуації щодо формування рентабельності виробництва молока аграрними підприємствами, дослідження впливу факторів витрат виробництва та цінової політики у формуванні ефективності виробництва молока й виділення напрямів щодо поліпшення їх використання. В роботі використано методичний інструментарій: діалектичний метод - у процесі визначення взаємозв'язків і проблемних сторін розвитку галузі; економіко-статистичні методи - під час дослідження динаміки і структури обсягів виробництва продукції в країні; методи економічного аналізу (абсолютних і відносних різниць, ланцюгових підстановок, факторного аналізу) - під час визначення результатів реалізації молока; метод аналізу і синтезу — під час дослідження окремих чинників, які вливають на прибутковість і рентабельність галузі та їх комплексного впливу; метод узагальнення під час систематизації вихідних даних, обгрунтування висновків та розробці пропозицій виробництву.

\section{ВИКЛАД ОСНОВНОГО МАТЕРІАЛУ ДОСЛІДЖЕННЯ}

У сучасних умовах молочний бізнес забезпечує прибуток, якщо рівень ціни буде конкурентним на ринку - цей чинник створює умови максимізації прибутку сільськогосподарських підприємств і завоювання певної частки на ринку. Сучасні тенденції розвитку аграрної економіки проявляються також у зростанні витрат виробництва через стрімке підвищення цін на матеріально-технічні та інші ресурси.

Об'єктивна оцінка рівня рентабельності виробництва молока в аграрних підприємствах грунтується на визначенні основних факторів, які впливають на ціну і собівартість продукції. Економічний аналіз рентабельності виробництва і реалізації молока передбачає визначення ефективності використання виробничого потенціалу галузі, передбачає визначення комплексу відповідних взаємопов'язаних показників, які характеризують поточний стан і динаміку економічних процесів у молочному скотарстві, виявлення резервів зростання прибутковості і рентабельності виробництва молока.

У підвищенні рентабельності виробництва молока різні форми господарств зацікавлені по різному. Зокрема, виробництво молока у господарствах населення має проблеми з рівнем якості і низькими закупівельними ціни. У зв'язку із підвищенням рівня вимог до європейських стандартів якості, введенням ряду нормативноправових актів дана категорія виробників, частка яких у виробництві залишається високою (71,8 \% у 2019 р.), взагалі може залишитися без ринків збуту. Об'єднання їх у кооперативи відбувається досить повільно, що обумовлено недосконалістю законодавства, негативним досвідом створених кооперативів, менталітетом відокремленого господарника, небажанням працювати в команді з іншими виробниками, складними відносинами 3 переробними підприємствами і закупівельними організаціями. Кооперація в молочній галузі в Україні не набула масового характеру, проте деякі кооперативи довели стійкість і функціонують в окремих регіонах. Тому у наступні роки можна 


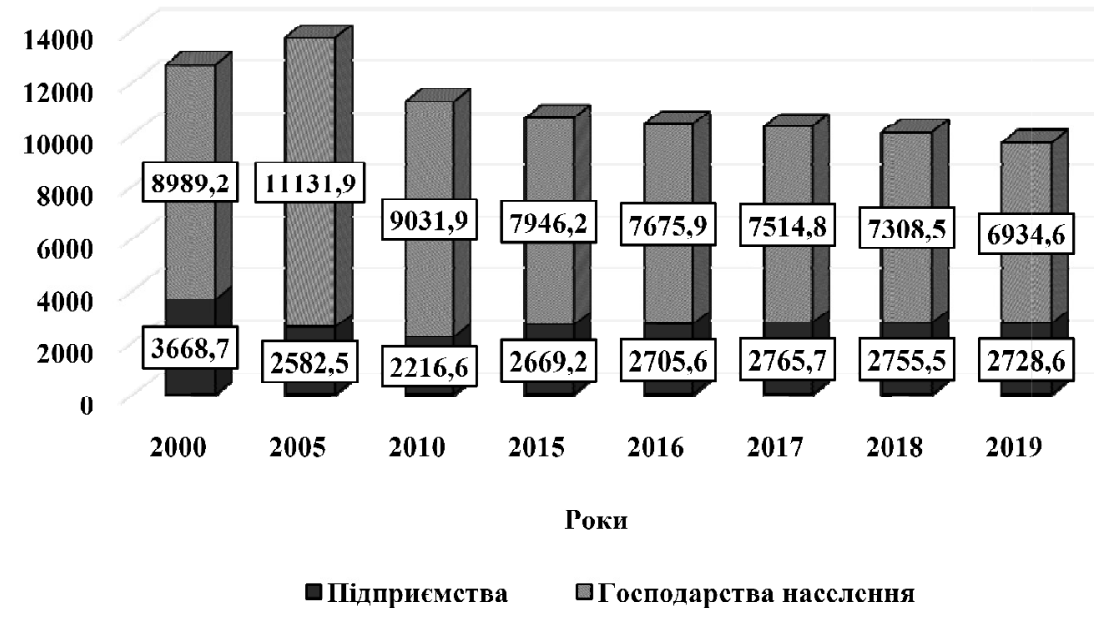

Рис. 1. Динаміка і структура виробництва молока за категоріями господарств, тис. т.

прогнозувати подальше скорочення виробництва молока домашніми господарствами під впливом низької закупівельної ціни, введення заборон на стихійну торгівлю, високої трудомісткості робіт, удорожчання кормів.

За досліджуваний період обсяги виробництва молока в усіх категоріях господарств зменшилося на 24,7 \% — від 12657,9 до 9663,2 тис. т (табл. 1).

Аослідження динаміки обсягів виробництва молока за категоріями господарств свідчить про наступне:

- динаміка виробництва має негативний тренд - обсяги виробництва скоротилися за 2000-2019 рр. від 12657,9 до 9663,2 тис. т - на $23,7 \%$

- у підприємствах і господарствах населення спад становить 25,6 та 22,9\% відповідно;

- фермерські господарства збільшили виробництво втричі, але їх частка становить лише 7,6 \% в категорії підприємств і 2,2 \% у загальній кількості;
- основними виробниками виступають господарства населення і забезпечують 71,8 \% від загального обсягу, проте більшість з них виробляють молоко для задоволення власних потреб, характеризуються низьким рівнем товарності і якості продукції, виконанням більшості технологічних процесів на основі ручної праці, 3 порушенням технологічних і санітарно-гігієнічних вимог.

Аинаміку і структуру виробництва молока за категоріями господарств відображає діаграма (рис. 1).

Основна проблема якості вітчизняної молокопродукції - переважне виробництво молока-сировини у домогосподарствах населення. Саме концентрація виробництва молока в особистих селянських господарствах є основною причиною низької якості вітчизняного молока, а отже, й продуктів його переробки [6]. Аля того, щоб господарства населення відповідали вимогам сучасного ринку, необхідна їх кооперація, удосконалення процесів виробництва

Таблиця 2. Розподіл підприємств за обсягами реалізації молока у 2019 р.

\begin{tabular}{|l|l|l|l|l|l|}
\hline \multicolumn{1}{|l|}{ Показники } & $\begin{array}{c}\text { Кількість } \\
\text { підприємств, } \\
\text { які } \\
\text { реалізували } \\
\text { молоко сире }\end{array}$ & $\begin{array}{c}\text { У \% до } \\
\text { загальної } \\
\text { кількості }\end{array}$ & $\begin{array}{c}\text { Вартість } \\
\text { реалізованої } \\
\text { продукції, } \\
\text { млн грн }\end{array}$ & $\begin{array}{c}\text { у \% до } \\
\text { загальної } \\
\text { кількості }\end{array}$ & $\begin{array}{c}\text { У середньому } \\
\text { на одне } \\
\text { підриємство, } \\
\text { тис. грн }\end{array}$ \\
\hline $\begin{array}{l}\text { Підприємства - } \\
\text { всього }\end{array}$ & 1185 & 100,0 & 20910,2 & 100,0 & 17645,7 \\
\hline $\begin{array}{l}\text { 3 них з обсягом } \\
\text { реалізації, тис. грн }\end{array}$ & & & & & \\
\hline до 100,0 & 42 & 3,5 & 1,7 & 0,0 & 40,5 \\
\hline $100,1-1000,0$ & 136 & 11,5 & 74,5 & 0,4 & 547,8 \\
\hline $1000,1-5000,0$ & 319 & 26,9 & 889,9 & 4,3 & 2789,7 \\
\hline $5000,1-10000,0$ & 207 & 17,5 & 1478,0 & 7,1 & 7140,1 \\
\hline $10000,1-20000,0$ & 203 & 20,6 & 10071,7 & 48,1 & 41277,5 \\
\hline $20000,1-100000,0$ & 244 & 2,9 & 5436,6 & 26,0 & 159900,0 \\
\hline більше 100000,0 & 34 & & & & \\
\hline
\end{tabular}




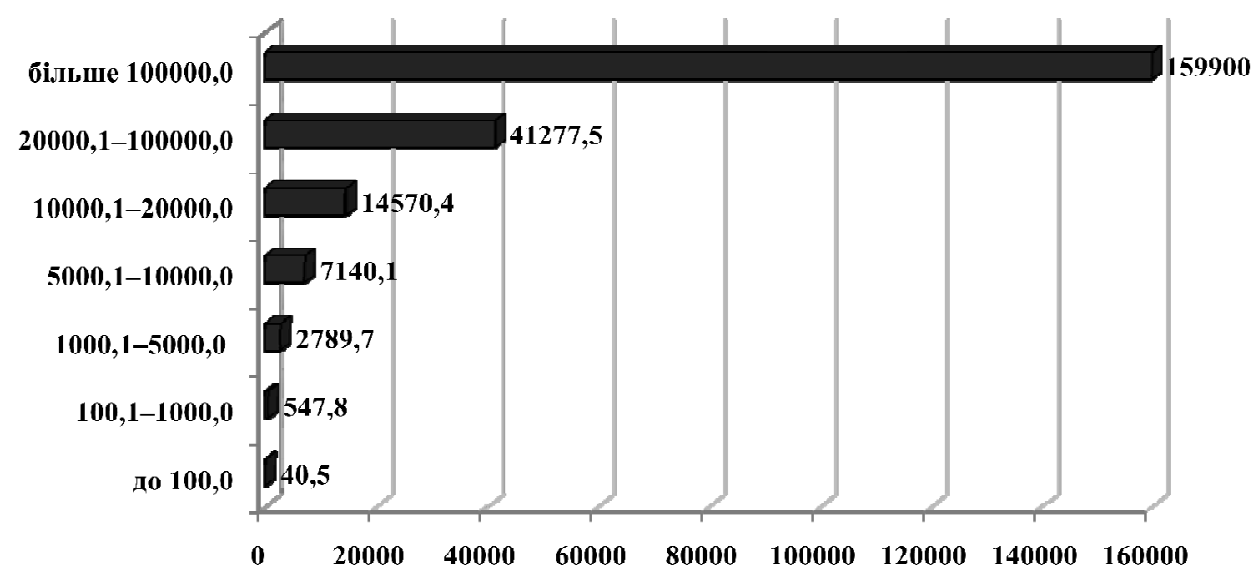

Рис. 2. Середні обсяги реалізації молока у розрахунку на одне підприємство, тис. грн

молока, очищення і охолодження, тобто забезпечення якісної складової виробничих процесів.

Експерти аграрного ринку на сьогодні вбачають перспективи у створенні спеціалізованих молочнотоварних ферм сімейного типу на основі розвитку домашніх господарств, які за довгі роки набули досвіду не тільки виробництва і ресурсного забезпечення, а й торгівлі молочною продукцією. Проблема підвищення якості молока і рентабельності може бути вирішена на основі механізації процесів доїння, придбання обладнання для його очищення і охолодження. Саме тут необхідна державна підтримка. Це єдиний шлях на сьогодні для дрібнотоварних виробників: сформувати серйозний пласт індустріальних виробників молока і молочної продукції шляхом створення сімейних ферм. Стимулювання створення молочних ферм промислового типу має бути в пріоритеті аграрної політики України. Необхідно розробити цілий організаційноекономічний механізм - від компенсації будівництва до генетики продуктивного стада, навчання господарів, який забезпечить отримання якісного конкурентоспроможного продукту [7].

Показники рентабельності відображаються у статистичній звітності по підприємствах, тому дослідження прибутковості виробництва у господарствах населення досить обмежене. Рішення про утримання корів господарства населення приймають на основі співвідношення доходів і витрат, орієнтуються на наявність грубих кормів, цін на сіно і концентровані корми, наявність зручних транспортних сполучень із ринками збуту.
Слід враховувати, що категорія підприємств-виробників молока неоднорідна за своєю структурою, частина 3 них мають молочнотоварні ферми, які не приносять великих доходів і прибутків, забезпечують певний рівень зайнятості працівників, у їх спеціалізації переважає продукція рослинництва. Тому низький рівень рентабельності виробництва молока для таких виробників не впливає на загальний економічний стан підприємства, галузь фінансується за остаточним принципом, існує як додаткова до основного виробництва, має низький рівень товарності через використання значної частини продукції всередині підприємства.

Підприємства з вузькою спеціалізацією, в яких молочне скотарство є провідною галуззю, мають найбільші перспективи розвитку в сучасних умовах за умови постійного моніторингу витрат виробництва і якості продукції, налагодження постійних зв'язків 3 переробними підприємствами. Вирішити нагальні питання розвитку молокопродуктового комплексу спроможні виробники, які ведуть бізнес на високоінтенсивній основі, мають достатньо ресурсів для впровадження сучасних технологій утримання поголів'я, забезпечення повноцінної годівлі, ефективних методів організації і мотивації праці, ефективної системи менеджменту. Бізнес-орієнтовані молочнотоварні ферми інвестують значні кошти $(6-10$ тис. дол. США в 


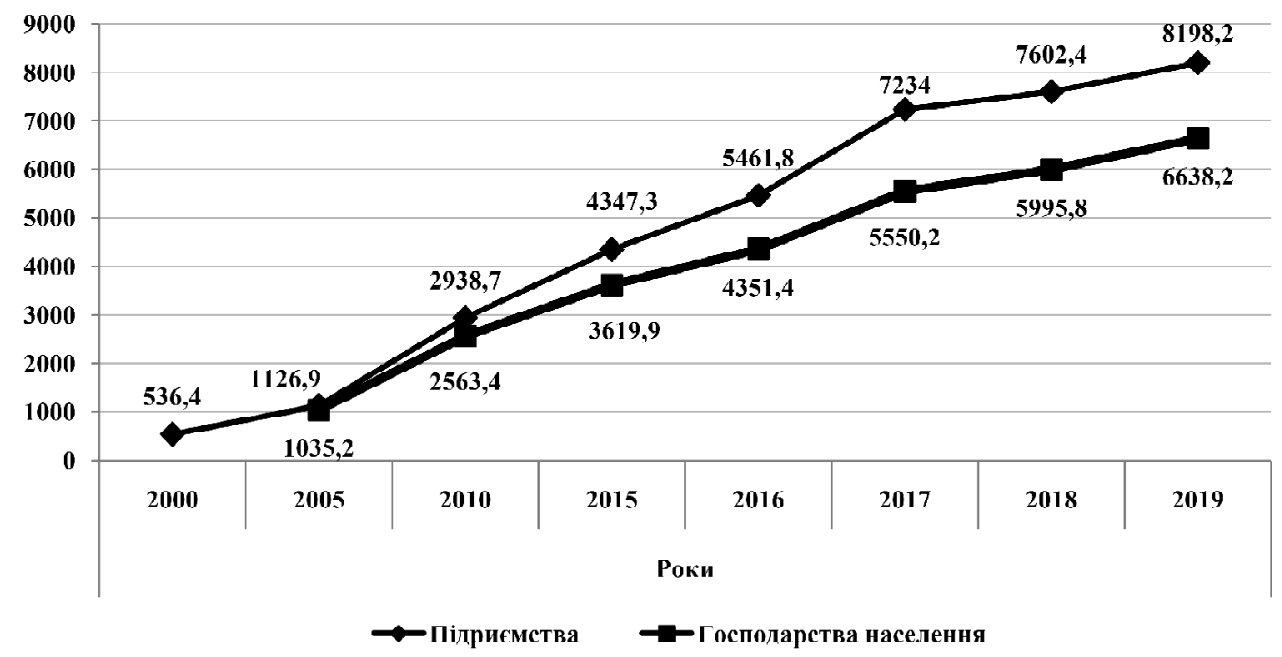

Рис. 3. Середні ціни на молоко, реалізоване підприємствами та господарствами населення, гривень за 1 тонну

одне стійломісце), з метою підвищення ефективності виробництва продукції. На основі використання наявної матеріально-технічної бази такі підприємства залишаються на ринку і забезпечують стабільні обсяги виробництва молока і відповідний рівень якості. Більше того, у першому півріччі 2020 р. молочнотоварні ферми забезпечили переробку навіть більшого обсягу молока, ніж у попередньому 2019 р.

Розподіл підприємств за обсягами реалізації молока у 2019 р. свідчить що найбільший дохід від реалізації забезпечують великі підприємства, які отримують більше 20 млн грн виручки, їх частка у загальній кількості підприємств $23,5 \%$, а у доходах $-74,1 \%$. Тобто 278 підприємств мають середній дохід від реалізації молока 55785,3 тис. грн і реалізують 3/4 всього обсягу реалізації в країні (табл. 2).

У той час як 865 підприємств $(73 \%$ від загальної кількості) займають $25,9 \%$ у доходах від реалізації, в середньому мають виручку 6243,0 тис. грн у розрахунку на одне підприємство. Графік відображає зростання середніх доходів виробників молока у розрахунку на одне підприємство (рис. 2).

Гречко А.В., Черножукова А.М. також пропонують формувати державну політику в молокопереробній галузі в залежності від сегментації товаровиробників молочної продукції. Зокрема, високоприбуткові підприємства-лідери потребують підтримки стратегічних проектів вдосконалення виробничого процесу. Аля підприємств, які мають низький рівень рентабельності, важливо формувати комплекс молокопереробних ферм з високим рівнем інвестиційної привабливості та впровадження інноваційних технологій. Технологічний стан підприємств молокопереробної галузі автори характеризують як задо- вільний, проте наголошують на необхідності заміни застарілого обладнання сучасними і надійними засобами механізації основних процесів, дотримання термінів їх експлуатації, комплексного повного оновлення системи засобів виробництва [8, с. 126-133].

Виробництво молока, на відміну від інших галузей тваринництва, забезпечує виробникам прибутки. Рівень рентабельності виробництва молока в аграрних підприємствах за період дослідження зростає від 1,8 до 20,6 \%, що є досить позитивною тенденцією (табл. 3).

У 2020 р. прибутковим у тваринництві залишилось лише виробництво молока - 3,8 млрд грн Проте досягнення $20 \%$ рентабельності недостатньо для розширеного ведення бізнесу і залучення значних інвестиційних ресурсів. Виробництво молока технологічно пов'язане із вирощування молодняку на м'ясо, а даний вид виробництва традиційно залишається збитковим (-27,1\% у 2019 р.). Тому загалом галузь скотарства для виробників $є$ збитковою. Крім того, ринкова ситуація 2020-2021 рр. відзначається рядом негативних процесів, які впливатимуть на формування рентабельності: у період карантину попит на молочні продукти у торговельній мережі зменшився через зниження купівельної спроможності населення, не працювали тривалий час бюджетні установи, була обмежена робота готельно-ресторанного бізнесу.

На рівень рентабельності виробництва молока негативний вплив мають процеси зростання цін на сировинні ресурси - кормові, енергетичні, ветеринарні, технічні і технологічні. Проте приріст продуктивності корів може нівелювати негативний вплив зростання вартості факторів інтенсифікації виробництва. 
АГРОСВIT № $7-8,2021$

Таблиця 4. Аналіз цінової ситуації на ринку молока-сировини

\begin{tabular}{|c|c|c|c|c|c|c|c|c|c|}
\hline \multirow{2}{*}{ Показники } & \multicolumn{8}{|c|}{ Роки } & \multirow{2}{*}{$\begin{array}{l}2019 \text { p. } \\
\text { y } \% \text { до } \\
2015 \text { p. }\end{array}$} \\
\hline & 2000 & 2005 & 2010 & 2015 & 2016 & 2017 & 2018 & 2019 & \\
\hline $\begin{array}{l}\text { Ціна реалізації підприємств, } \\
\text { грн/ т }\end{array}$ & 536,4 & 1126,9 & 2938,7 & 4347,3 & 5461,8 & 7234,0 & 7602,4 & 8198,2 & 188,6 \\
\hline у \% до попереднього року & - & 210,0 & 260,8 & 147,9 & 125,6 & 132,4 & 105,0 & 107,8 & - \\
\hline $\begin{array}{l}\text { Ціна реалізації господарств } \\
\text { населення, грн/ т }\end{array}$ & - & 1035,2 & 2563,4 & 3619,9 & 4351,4 & 5550,2 & 5995,8 & 6638,2 & 183,4 \\
\hline у \% до попереднього року & - & - & 247,6 & 141,2 & 120,2 & 127,5 & 108,0 & 110,7 & - \\
\hline Співвідношення ціни, \% & - & 91,8 & 87,2 & 83,2 & 79,7 & 76,7 & 78,9 & 81,0 & \\
\hline
\end{tabular}

Молочний ринок і ціноутворення загалом перебувають під впливом економічної ситуації у країні, регулюється попитом і пропозицією. У 2020-2021 рр. зростання внутрішньої ціни на складові комбікормів стало загрозою тваринництву щодо втрати прибутків. Аля молочного напряму скотарства і на сьогодні існує величезний ризик переходу до зони збитковості, адже галузь тривалий період часу перебуває у стадії стагнації, потребує не тільки державної підтримки, а й системного підходу щодо ефективних стратегічних рішень на рівні кожного господарюючого суб'єкта, регіонів та країни в цілому. Рівень рентабельності виробництва молока в Україні у 2020 р. Аля більшості підприємств зменшився в середньому на $3 \%$, навіть підвищення закупівельної ціни на молоко-сировину не зупинило падіння рентабельності.

Щодо середніх закупівельних цін на молоко, реалізоване підприємствами і господарствами населення, слід відзначити їх щорічний приріст і досягнення певного максимального рівня, коли подальше зростання ціни спричинить збитковість переробних підприємств і зростання експорту молочної продукції. Середня ціна реалізації молока підприємствами у 2019 р. становила 8198,2 грн/т, що на 7,8 \% вище 2018 р. (рис. 3).

Одночасно зростає і закупівельна ціна для господарств населення до 6638,2 грн/т (на $10,7 \%$ до рівня 2018 р.), проте розрив у ціні, порівняно з підприємствами, з кожним роком зро- стає. Підприємства забезпечують свою цінову перевагу за рахунок якісних показників, у той час як господарства населення здають молоко низької якості і, відповідно, втрачають у ціні. Умови ринку вимагають від них термінової зміни всієї системи ведення господарства, перебудови систем виробництва продукції, підвищення рівня механізації процесів доїння, створення міцної кормової бази, налагодження постійних зв'язків з ринками збуту.

Якщо у 2016-2017 рр. щорічний приріст цін становив 25-32\%, то у 2018-2019 рр. - лише 5-11\%, що свідчить про стабілізацію ринку і неможливість подальшого зростання цін (табл. 4).

Низькі закупівельні ціни від переробних підприємств стали головним негативним фактором для сільськогосподарських підприємств до скорочення поголів'я і виробництва молока. Проте експерти ринку наголошують про неможливість подальшого зростання закупівельної ціни, яка досить висока порівняно з європейськими країнами та загрожує збитковістю молокопереробним підприємствам. Тому аграрним підприємствам залишається в цій складній ситуації єдиний вихід - економія на всіх видах ресурсів, впровадження ресурсозберігаючих технологій, підвищення генетичного потенціалу корів 3 метою зниження собівартості виробництва молока.

Тому виробникам не варто сподіватися на перспективу і очікувати підвищення ціни,

\section{Таблиця 5. Розподіл підприємств-виробників молока} за середніми цінами реалізації у 2019 р.

\begin{tabular}{|c|c|c|c|c|c|}
\hline \multirow[b]{2}{*}{$\begin{array}{c}\text { Категорії } \\
\text { підприємств }\end{array}$} & \multicolumn{2}{|c|}{$\begin{array}{c}\text { Кількість } \\
\text { підприємств }\end{array}$} & \multicolumn{2}{|c|}{$\begin{array}{c}\text { Обсяг реалізованої } \\
\text { продукції }\end{array}$} & \multirow{2}{*}{$\begin{array}{c}\text { Середня } \\
\text { потужність } \\
\text { підприємства, } \\
\text { т }\end{array}$} \\
\hline & одиниць & $\begin{array}{c}\text { у\% до } \\
\text { загальної } \\
\text { кількості }\end{array}$ & тис. т & $\begin{array}{c}\text { у \% до } \\
\text { загальної } \\
\text { кількості }\end{array}$ & \\
\hline Підприємства & 1185 & 100,0 & 2550,5 & 100,0 & 2152,3 \\
\hline \multicolumn{6}{|l|}{$\begin{array}{l}3 \text { них із середньою } \\
\text { ціною реалізації, } \\
\text { грн за } 1 \mathrm{~T}^{2}\end{array}$} \\
\hline до 4000,0 & 6 & 0,5 & 0,0 & 0,0 & - \\
\hline $4000,1-6000,0$ & 51 & 4,3 & 12,4 & 0,5 & 243,1 \\
\hline $6000,1-8000,0$ & 727 & 61,4 & 882,2 & 34,6 & 1213,5 \\
\hline $8000,1-10000,0$ & 376 & 31,7 & 1627,8 & 63,8 & 4329,3 \\
\hline більше 10000,0 & 25 & 2,1 & 28,1 & 1,1 & 1124,0 \\
\hline
\end{tabular}


слід вести пошук внутрішніх резервів зниження виробничих витрат, підвищення ефективності використання всіх видів ресурсів, удосконалення організаційно-управлінських процесів.

Структуризація підприємств-виробників молока за середніми цінами реалізації свідчить, що із 1185 підприємств лише 57 (4,8\%) здавали молоко за ціною на рівні господарств населення - нижче 6 тис. грн/т (табл. 5).

Основна частина виробників (727, або 61,4\%) продавали молоко в діапазоні 6-8 тис. грн, їх середня потужність 1213,5 т на одне підприємство. Основна категорія виробників 376 підприємств $(31,7$ \% від загальної кількості) реалізували молоко за ціною 8-10 тис. грн /т. Питома вага такої категорії у обсягах реалізованої продукції становить 63,8\%, їх середня потужність 4329,3 т у розрахунку на одне підприємство, що підтверджує попередні висновки про перевагу великотоварного виробництва на ринку молока.

Ціна на молоко-сировину є високою, але подальше їі зростання може впливати на приріст імпорту. Середньозважена ціна на молоко в 2021 р. буде зростати і може досягти 12,82 грн/кг, загалом рівень цін буде залежати від рівня і стабільності попиту, майбутніх цін на корми та інфляційних процесів.

Вітчизняний молочний бізнес втрачає споживачів і фінансові ресурси, які могли бути залучені від продажів. Аналітики молочного ринку прогнозують падіння дохідності виробленого молока до 1-17\%. Причому 17\% зможуть досягти тільки високопродуктивні господарства, які забезпечують надої понад 9 тис. кг на корову і мають необхідні інвестиції на переобладнання ферм. Таких підприємств серед загальної кількості - до 30\%. Решта на сьогодні балансують на межі лише 1\% маржинальності та перебувають перед непростим для себе вибором подальшого розвитку. Вагомою загрозою прибутковості $€$ також зниження платоспроможного попиту населення під впливом пандемії, інфляційні процеси, зростання безробіття.

Відповідно до попередніх підсумків 2020 р., до України імпортовано 47 тис. т сирів, 28 тис. т продукції з незбираного молока, 12 тис. т масла. Якщо це все перевести в сировину, то по імпорту отримали 1 млн т молока. Українські молокопереробні підприємства переробили за 2020 р. 3,7 млн т молока. Тому імпорт складає майже $30 \%$ від того, що переробляє вітчизняна молочна переробна галузь. Водночас молокопереробні підприємства в Україні працюють на межі збитковості, не мають коштів на розширене відтворення, цей бізнес залишається непривабливим для інвесторів. 3 ринку вибувають збанкрутілі підприємства: якщо в 1990 р. в Україні було 670 молокопереробних підприємств, то в 2019 р. свою діяльність показали 178.

Впровадження підвищених вимог до безпечності та якості молока і молочних продуктів відтерміновано на два роки до 01 січня 2023 р. Тому цей час повинні використати ефективно як виробники молока-сировини, так і молокопереробні підприємства. Продовження на два роки перехідного періоду щодо відповідних заходів державного контролю виробництва та введення в обіг сирого молока повинно стати часом для узгодження відносин виробників і переробників молока, підвищення ефективності виробництва і рентабельності, створення ефективного організаційно-економічного механізму функціонування молочної галузі загалом. Участь держави в даному процесі повинна бути спрямована на розробку і успішну реалізацію Стратегії розвитку молочного скотарства та молокопереробної галузі, формування відповідної політики, розподіл функцій компетентних органів, в тому числі і Аержпродспоживслужби.

У розрізі постачальників сирого молока на переробку питома вага молока першого гатунку, за результатами дев'яти місяців 2020 р., також залишається суттєвою, а саме: від сільськогосподарських підприємств - 31,4\%; від господарств населення - 68,6\%.

Підвищення рівня рентабельності саме виробників молока-сировини у молокопродуктовому ланцюзі є визначальним чинником подальшого ефективного розвитку молочної галузі загалом. Тому важливо на рівні господарюючих суб'єктів проводити економічний аналіз прибутковості і рентабельності виробництва, методичні рекомендації до якого широко висвітлені в навчальній літературі [9; 10]. Факторний аналіз фінансових результатів від реалізації молока в аграрних підприємствах грунтується на даних річної статистичної звітності підприємства форми № 50-сг "Звіт про основні економічні показники роботи сільськогосподарських підприємств" та форми № 21-заг "Звіт про реалізацію продукції сільського господарства". Об'єктом аналізу виступає підприємство, яке в Херсонській області є одним із найбільших виробників молока. Проведені розрахунки свідчать, що підприємство щорічно нарощує обсяги реалізації молока — від 130175 до 147032 ц, абсолютний приріст становить 16857 ц, відносний $-12,9 \%$ (табл. 6). 
Таблиця 6.Факторний аналіз фінансових результатів від реалізації молока

\begin{tabular}{|l|c|c|c|c|c|}
\hline \multirow{2}{*}{\multicolumn{1}{|c|}{ Показники }} & \multicolumn{3}{|c|}{ Роки } & \multicolumn{2}{c|}{$\begin{array}{c}\text { Відхилення 2019 p. } \\
\text { від 2017 } \text { р., -) }\end{array}$} \\
\cline { 2 - 6 } & 2017 & 2018 & 2019 & абсолютне & відносне, \%* \\
\hline $\begin{array}{l}\text { Реалізація продукції у фізичній } \\
\text { масі, ц }\end{array}$ & 130175 & 135702 & 147032 & 16857 & 112,9 \\
\hline $\begin{array}{l}\text { Чистий дохід (виручка) від } \\
\text { реалізації, тис. грн }\end{array}$ & 97875,5 & 104971,8 & 123283,9 & 25408,1 & 126,0 \\
\hline Повна собівартість, тис. грн & 69459,4 & 88364,3 & 113797,2 & 44337,8 & 163,8 \\
\hline Прибуток (збиток), тис. грн & 28416,1 & 16607,5 & 9486,7 & $-18929,4$ & 33,4 \\
\hline $\begin{array}{l}\text { У розрахунку на 1 ц } \\
\text { реалізованої продукції, грн: }\end{array}$ & & & & & \\
\hline - повна собівартість & 533,58 & 651,16 & 773,96 & 240,38 & 145,1 \\
\hline - середня реалізаційна ціна & 751,87 & 773,54 & 838,48 & 86,61 & 111,5 \\
\hline - прибуток (збиток) & 218,29 & 122,38 & 64,52 & $-153,77$ & 29,6 \\
\hline $\begin{array}{l}\text { Загальна зміна прибутку } \\
\text { (збитку) порівняно із } \\
\text { попереднім роком, тис. грн }\end{array}$ & - & $-11808,6$ & $-7120,8$ & $\mathrm{x}$ & $\mathrm{x}$ \\
\hline $\begin{array}{l}\text { у т. ч. за рахунок збільшення } \\
\text { (зменшення): }\end{array}$ & & & & & $\mathrm{x}$ \\
\hline - кількості продукції & $\mathrm{x}$ & 1206,5 & 1386,5 & $\mathrm{x}$ & $\mathrm{x}$ \\
\hline - собівартості & $\mathrm{x}$ & $-15955,8$ & $-18055,5$ & $\mathrm{x}$ & $\mathrm{x}$ \\
\hline - ціни реалізації & $\mathrm{x}$ & 2940,7 & 9548,2 & $\mathrm{x}$ & $\mathrm{x}$ \\
\hline
\end{tabular}

Приріст чистого доходу (виручки) у 2019 р. 29408,1 тис. грн (26,0\%), порівняно з 2017 р. Aле, при цьому зростає повна собівартість реалізованої продукції і перевищує приріст доходів. Витрати на виробництво і реалізацію продукції зросли на 44337,8 тис. грн, або на 63,8 \%. Це привело до зниження прибутковості на 18929,4 тис. грн В цілому прибуток від реалізації молока у 2019 р. становить лише 33,4 \% до рівня 2017 р.

Така ситуація негативно позначилася і на фінансових результатах діяльності всього підприємства. Тенденція до зниження прибутковості виробництва молока повинна стати стимулом для керівників підрозділів, менеджменту підприємства до пошуку резервів економії витрат, раціоналізації систем утримання корів і рівня годівлі, удосконалення структури і обороту стада.

Проведений факторний аналіз прибутку від реалізації молока свідчить, що у 2018 р. прибуток зменшився на 11808,6 тис. грн. Позитивний вплив на фінансовий результат мали кількість реалізованої продукції - 1206,5 тис. грн та приріст ціни реалізації-2940,7 тис. грн. Проте цим чинникам не вдалося нівелювати негативний вплив приросту собівартості обсягом 15955,8 тис. грн. У 2019 р. прибуток зменшився, порівняно з 2018 р., ще на 7120,8 тис. грн, у тому числі кількість реалізованого молока сприяла приросту прибутковості у сумі 1386,5 тис. грн, збільшення ціни реалізації від 773,54 до 838,48 грн також забезпечило приріст прибутку на 9548,2 тис. грн. А зростання виробничих і peaлізаційних витрат привело до негативного впливу на прибуток у розмірі 18055,5 тис. грн.
Отже, дослідження основних чинників, які впливають на фінансові результати від реалізації молока свідчать, що прибуток зростає під впливом поступового нарощування обсягів реалізації продукції та приросту ціни. Проте темпи росту собівартості продукції перевищують позитивний вплив ціни і кількості, що у підсумку привело до зниження суми прибутку на 18929,4 тис. грн, або на 66,6 \%. Факторний аналіз свідчить, що пошук резервів зростання прибутковості ведення молочної галузі повинен бути зосереджений, в першу чергу, на оптимізації витрат на виробництво і збут молока, загальновиробничих і адміністративних витратах. Приріст обсягів виробництва і реалізації молока за рахунок збільшення поголів'я корів та їх продуктивності гарантує збільшення доходів у наступних періодах. Підвищення ціни реалізації забезпечується за рахунок підвищення якості молока і доведення його до відповідної кондиції, впровадження нових каналів збуту, встановлення взаємовигідних договірних відносин з переробними підприємствами.

Наступним етапом дослідження ефективності виробництва молока є проведення економічного аналізу рівня рентабельності (табл. 7).

Проведені розрахунки визначають зміни у показниках рентабельності виробництва та фактори, що зумовили ці процеси. На основі вихідної інформації визначено, що у 2019 р. рівень рентабельності молока менше на $32,6 \%$, порівняно з 2017 р., коли кожна витрачена гривня в галузі приносила 40,9 коп. прибутку. Ціна реалізації 1 ц зросла на 86,61 грн, або 11,5\%, повна собівартість - на 240,38 грн $(45,1 \%)$. Що і 
Таблиця 7. Факторний аналіз рівня рентабельності реалізації молока

\begin{tabular}{|l|l|l|l|l|}
\hline \multirow{2}{*}{\multicolumn{1}{|c|}{ Показники }} & \multicolumn{2}{c|}{ Роки } & \multicolumn{2}{c|}{$\begin{array}{c}\text { Відхилення 2019 p. } \\
\text { від 2017 р. (+, -) }\end{array}$} \\
\cline { 2 - 5 } & 2017 & 2019 & \multicolumn{1}{c|}{$\begin{array}{c}\text { абсо- } \\
\text { лютне }\end{array}$} & $\begin{array}{c}\text { відносне, } \\
\%\end{array}$ \\
\hline $\begin{array}{l}\text { У розрахунку на 1 ц реалізованої } \\
\text { продукції: }\end{array}$ & & & & \\
\hline - повна собівартість, грн & 533,58 & 773,96 & 240,38 & 145,1 \\
\hline - середня реалізаційна ціна, грн & 751,87 & 838,48 & 86,61 & 111,5 \\
\hline - прибуток (збиток), грн & 218,29 & 64,52 & $-153,77$ & 29,6 \\
\hline Рівень рентабельності, \% & 40,9 & 8,3 & $-32,6$ в. п. & х \\
\hline $\begin{array}{l}\text { Загальна зміна рентабельності } \\
\text { порівняно із попереднім роком, п. п. }\end{array}$ & - & $-32,6$ & х & х \\
\hline $\begin{array}{l}\text { в т.ч. за рахунок зміни: } \\
\text { - ціни реалізації }\end{array}$ & - & 11,2 & х & х \\
\hline - собівартості одиниці продукції & - & $-43,8$ & х & х \\
\hline
\end{tabular}

стало причиною зменшення прибутку в розрахунку на 1 ц від 218,29 до 64,52 грн.

Питома вага виробництва молока вищого гатунку та молока виробленого підприємствами найближчим часом буде зростати. Операційна рентабельність значною мірою буде залежати від цін на зернові і кормові культури та рівня цін білкові складові комбікормів.

Ефективний розвиток галузі молочного скотарства в аграрних підприємствах вимагає значних витрат на формування кормової бази, вирощування ремонтного молодняку Аля оновлення вікової структури основного стада, утримання приміщень, оплати праці основних працівників. Зростання витрат у досліджуваному підприємстві стало причиною зниження прибутковості і рентабельності продукції. Визначенням шляхів підвищення ефективності виробництва грунтується на технологічних, організаційних та економічних чинниках.
Зниження рівня рентабельності виробництва свідчить про необхідність удосконалення системи управління витратами, введення технологічних новацій тільки за умови чіткого визначення періодів їх окупності, постійного контролю за витратами кормів, енергетичних та інших видів матеріальних витрат.

Найбільший вплив на рівень собівартості має вартість і якість кормів. Можливі шляхи здешевлення кормового раціону $є$ основою зниження собівартості продукції. Негативний вплив на рентабельність молока в аграрних підприємствах має підвищення цін на складові витрат, зокрема, на рослинний білок, який є базою Аля кормів у тваринництві і має подвійний приріст ціни на світових ринках.

Розроблена структурно-логічна схема впливу чинників на собівартість продукції у молочному скотарстві дозволяє концентрувати увагу на можливих варіантах оптимізації витрат і визначенні резервів їх зниження (табл. 8).

\section{Таблиця 8. Основні чинники формування собівартості молока}

\begin{tabular}{|c|c|c|c|c|}
\hline \multicolumn{5}{|c|}{ Рівень собівартості продукції } \\
\hline $\begin{array}{l}\text { Матеріальні } \\
\text { витрати }\end{array}$ & $\begin{array}{l}\text { Витрати на } \\
\text { оплату праці }\end{array}$ & \multicolumn{2}{|c|}{$\begin{array}{c}\text { Інші прямі та загальновиробничі } \\
\text { витрати }\end{array}$} & $\begin{array}{c}\text { Продуктивність } \\
\text { корів }\end{array}$ \\
\hline $\begin{array}{l}\text { Витрати кормів на } \\
1 \text { ц молока }\end{array}$ & $\begin{array}{l}\text { Продуктивність } \\
\text { праці }\end{array}$ & $\begin{array}{l}\text { Рівень механізації } \\
\text { виробництва }\end{array}$ & $\begin{array}{l}\text { Організаційно- } \\
\text { управлінські } \\
\text { чинники }\end{array}$ & $\begin{array}{l}\text { - генетичний } \\
\text { потенціал }\end{array}$ \\
\hline $\begin{array}{l}\text { - кормомісткість } \\
\text { продукції }\end{array}$ & $\begin{array}{l}\text { - основна i } \\
\text { додаткова } \\
\text { зарплата }\end{array}$ & - фондоозброєність & $\begin{array}{l}\text { - спеціалізація } \\
\text { виробничих } \\
\text { підрозділів і їх } \\
\text { взаємозв'язки }\end{array}$ & $\begin{array}{l}\text { - кормова база, } \\
\text { рівень і якість } \\
\text { годівлі }\end{array}$ \\
\hline $\begin{array}{l}\text { Інші складові } \\
\text { матеріальних } \\
\text { витрат } \\
\text { (ветеринарні } \\
\text { препарати, } \\
\text { водопостачання, } \\
\text { енергопостачання, } \\
\text { вартість послуг } \\
\text { сторонніх } \\
\text { організацій) } \\
\end{array}$ & $\begin{array}{l}\text { - система } \\
\text { преміювання }\end{array}$ & - енергоозброєність & $\begin{array}{l}\text { - концентрація } \\
\text { виробництва, } \\
\text { економія на } \\
\text { масштабах }\end{array}$ & $\begin{array}{l}\text { - системи } \\
\text { утримання і } \\
\text { обслуговування }\end{array}$ \\
\hline $\begin{array}{l}\text { - матеріаломісткість } \\
\text { продукції }\end{array}$ & $\begin{array}{l}\text { - моральне } \\
\text { заохочення }\end{array}$ & $\begin{array}{l}\text { - енерго- і } \\
\text { ресурсоощадні } \\
\text { технології }\end{array}$ & $\begin{array}{l}\text { - раціональна } \\
\text { організація } \\
\text { праці і } \\
\text { виробничих } \\
\text { процесів } \\
\end{array}$ & $\begin{array}{l}\text { - структура i } \\
\text { оборот стада }\end{array}$ \\
\hline
\end{tabular}


В якості удосконалення системи управління на підприємствах необхідно звертати увагу на ефективність організації виробничого процесу, шляхи скорочення загальновиробничих, адміністративних і збутових витрат, що суттєво впливає на зниження собівартості продукції. 3 метою підвищення прибутковості галузі молочного скотарства великим підприємствам доцільно залучити фахівців 3 маркетингу, які можуть визначити оптимальну ціну реалізації, орієнтуються і враховують основні тенденції аграрного ринку.

Цінова ситуація на ринку молока перебуває під впливом введення більш вимогливих законодавчих нормативів до якості молока i збільшення частки підприємств, що здають молоко на переробні підприємства. Тому динаміка цін на молоко $є$ позитивною і передбачається подальший позитивний ціновий тренд. У структурі реалізації молока на переробні підприємства мають перевагу підприємства. Ціна реалізації в цій категорії значно перевищує ціну від господарств населення. 3 нарощуванням обсягів виробництва молока спеціалізованим підприємствам життєво необхідна інтеграція з переробними підприємствами. Відповідно змінюється й цінова політика. Завдяки партнерським відносинам переробним підприємством, якому виробник продає молоко-сировину, ціна встановлюється вище середньої закупівельної, проводиться цінова політика щодо режиму постійної ціни, використовуються інші цінові поступки.

Оптимізація галузей і поглиблення спеціалізації дає можливість визначити параметри виробничих систем підприємств, які забезпечують збалансований розвиток скотарства та кормовиробництва, первинної переробки молока, транспортного обслуговування доставки до молокопереробних підприємств. Водночас формуються умови для раціонального використання земельних, матеріальних і трудових ресурсів, впровадження інноваційних технологій виробництва продукції.

У молочній галузі будуть і далі посилюватися позиції потужних високоефективних підприємств та вихід із ринку неефективних господарств, збільшуватися число компаній, які ведуть детальний облік рентабельності виробництва і реалізації продукції, активно працюють над оптимізацією витрат на виробництво.

\section{ВИСНОВКИ}

Вирішити нагальні питання розвитку молокопродуктового комплексу спроможні виробники, які ведуть бізнес на високоінтенсивній основі, мають достатньо ресурсів для впровадження сучасних технологій утримання поголів'я, забезпечення повноцінної годівлі, ефективних методів організації і мотивації праці, ефективної системи менеджменту. Найважливішим показником ефективності виробництва продукції скотарства (молока і м'яса) є рентабельність. На його величину безпосередньо або побічно впливають цілий ряд чинників. Основними 3 них є якість і собівартість продукції, канали реалізації і реалізаційна ціна. В зв'язку з випередженням темпів росту затрат над ціною реалізації продукції рівень рентабельності залишається поки що низьким. На рівень рентабельності виробництва молока негативний вплив мають процеси зростання цін на сировинні ресурси - кормові, енергетичні, ветеринарні, технічні і технологічні. Проте приріст продуктивності корів може нівелювати негативний вплив вартості факторів інтенсифікації виробництва.

Господарства населення, щоб стати конкурентоспроможними на ринку молока і молочної продукції, повинні пройти етапи об'єднання зусиль 3 метою створення міцної кормової бази, кооперації у сфері забезпечення високопродуктивним поголів'ям і ветеринарними препаратами, створення стабільних маркетингових каналів збуту на основі співпраці з переробними підприємствами або налагодження власної переробної бази і торговельної мережі. Ефективні стратегічні рішення щодо об'єднання дрібних виробників, робота над якістю молока, забезпечення виробничих процесів відповідним обладнанням $€$ запорукою успішного ведення молочного бізнесу в секторі малих виробників.

Аослідження основних чинників, які впливають на фінансові результати від реалізації молока на рівні підприємств свідчать, що прибуток зростає під впливом поступового нарощування обсягів реалізації продукції та приросту ціни. Проте темпи росту собівартості продукції перевищують позитивний вплив ціни і кількості, що у підсумку спричинює зниження суми прибутку. Зниження прибутковості виробництва молока відбувається під впливом зростання виробничих витрат. Активна робота великих підприємств над оптимізацією виробничих процесів, управління витратами, економія ресурсів з метою зниження собівартості продукції $є$ основою підвищення рівня рентабельності.

Загалом з метою підвищення рентабельності виробництва молока в галузі необхідно забезпечити технологічну та технічну модер- 
нізацію засобів виробництва, придбати нове сучасне обладнання на основі державної підтримки та внутрішніх фінансових резервів; впроваджувати ресурсо- та енергозберігаючі технології для забезпечення конкурентних переваг на основі низької собівартості; створити кормову базу на основі власного виробництва кормів, удосконалення структури кормового клину у сівозміні, забезпечення протеїнового балансу.

Організаційно-технологічне перезавантаження галузі забезпечить якісно новий рівень прибутковості та конкурентоспроможності на національному і світовому ринку. Створення ефективної системи збуту продукції, налагодження постійних зв'язків із молокопереробними підприємствами є умовою посилення конкурентних позицій виробника молока-сировини та підвищення прибутковості діяльності. Таким чином, рівень рентабельності виробництва молока - це результат реалізації виробничих, маркетингових, інноваційних, економічних, організаційних та інших можливостей підприємства, регіону, галузі та країни загалом.

\section{$\Lambda$ ітература:}

1. Сільське господарство України за 2019 рік: статистичний збірник. / За ред. Прокопенко О.К.: Аержавна статистична служба України, 2020. $230 \mathrm{c}$.

2. Петриченко О. Ефективність виробництва молока у сільськогосподарських підприємствах. Економічний дискурс. Міжнародний науковий журнал. 2018. Вип. 2. С. 62-72.

3. Ільчук М.М., Коновал I.А. Підвищення конкурентоспроможності продукції скотарства в Україні. Економіка АПК. 2016. № 5. C. $51-59$.

4. Супрун О.М., Величко Є.І., Іваннікова I.С. Вплив цінових чинників на виробництво молока в сільскогосподарьких підприємствах. Економіка АПК. 2015. № 12. С. 64-67.

5. Яворська T.І., Загнітко И.А. Вплив витрат і ціни реалізації на ефективність виробництва молока в сільськогосподарських підприємствах регіону. Економіка АПК. 2015. № 6. С. 53-59.

6. Бубела Т.3. Методи та засоби визначення показників якості продукції: навчальний

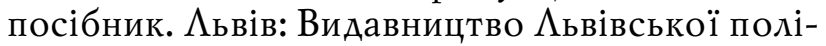
техніки, 2015. 292 с.

7. AlexLissitsa_analytics \#AlexLissitsa_politics URL: https://www.facebook.com/ Alissitsa/posts/ 2743216356006478 (дата звернення 03.03.2021).

8. Гречко А.В., Черножукова А.М. Шляхи підвищення прибутковості молокопереробних підприємств України. Сучасні проблеми економіки і підприємництво. 2018. Вип. 21. С. 126-133.

9. Паланюк Н.А., Петренко В.Г. Економічний аналіз: навчальний посібник. К.: Аграрна освіта, 2010.252 с.

10. Єгорова О.В., Аорогань-Писаренко М.О., Аитвин О.Ю. Аналіз господарської діяльності: навчальний посібник для студентів вищих навчальних закладів аграрного профілю. Полтава: РВВА ПААА, 2016. 308 с.

\section{References:}

1. State Statistics Service of Ukraine (2020), "Sil's'ke hospodarstvo Ukrainy za 2019 rik. Statystychnyj zbirnyk" [Agriculture of Ukraine for 2019: statistical collection], Derzhavna statystychna sluzhba Ukrainy, Kyiv, Ukraine.

2. Petrychenko, O. (2018), "Efficiency of milk production in agricultural enterprises", Ekonomichnyj dyskurs. Mizhnarodnyj naukovyj zhurnal, vol. 2, pp. 62-72.

3. Il'chuk, M.M. and Konoval, I.A. (2016), "Increasing the competitiveness of livestock products in Ukraine", Ekonomika APK, vol. 5, pp. 51-59.

4. Suprun, O.M. Velychko, Ye.I. and Ivannikova, I.S. (2015), "Ivannikova Influence of price factors on milk production in agricultural enterprises", Ekonomika APK, vol. 12, pp. 64-67.

5. Yavors'ka, T.I. and Zahnitko, L.A. (2015), "Zagnitko Influence of costs and selling prices on the efficiency of milk production in agricultural enterprises in the region", Ekonomika APK, vol. 6, pp. 53-59.

6. Bubela, T.Z. (2015), Metody ta zasoby vyznachennia pokaznykiv iakosti produktsii [Methods and means of determining product quality indicators: a textbook], Vydavnytstvo L'vivs'koi politekhniky, Lviv, Ukraine.

7. AlexLissitsa_analytics (2021), "\#AlexLissitsa_politics", avaīlable at: https://www.facebook.com/Alissitsa/posts/2743216356006478 (Accessed 10 April 2021).

8. Hrechko, A.V. and Chernozhukova, A.M. (2018), "Ways to increase the profitability of dairy enterprises in Ukraine", Suchasni problemy ekonomiky i pidpryiemnytstvo, vol. 21, pp. 126-133.

9. Palaniuk, N.A. and Petrenko, V.H. (2010), Ekonomichnyj analiz [Economic analysis], Ahrarna osvita, Kyiv, Ukraine.

10. Yehorova, O.V. Dorohan'-Pysarenko, L.O. and Lytvyn, O.Yu. (2016), Analiz hospodars'koi diial'nosti [Analysis of economic activity: a textbook for students of higher educational institutions of agricultural profile], RVVD PDAA, Poltava, Ukraine.

Стаття надійшла до редакиії 19.04.2021 p. 
УAK 330.341 .1

\title{
B. А. Кельман,
} аспірант кафедри обліку та оподаткування і маркетингу, Мукачівський Аержавний університет

ORCID ID: 0000-0002-4048-2484

DOI: $10.32702 / 2306-6792.2021 .7-8.121$

\section{СУЧАСНI ОСОБАИВОСТI ТА МОАЕАI ААМІНІСТРУВАННЯ ТА УПРАВАІННЯ МЕРЕЖЕВОГО РИТЕЙЛУ}

\author{
V. Kelman, \\ Postgraduate student of the Department of Accounting, Taxation and Marketing, \\ Mukachev State University
}

\section{CURRENT FEATURES AND MODELS OF NETWORK RETAIL ADMINISTRATION AND MANAGEMENT}

\footnotetext{
Мережа ритейлу - це штучне об'єАнання об'єктів ритейлу, віАтак Аля їі функціонування необхідний перехіА Ао однорідності ії членів, а отже, функціонування за єАиними правилами всередині і ззовні мережі. При цьому у такій мережі формуються моделі адміністрування та управління. Виходячи з наведених положень, метою статті $є$ опис сучасних особливостей та моделей аАміністрування мережевого ритейлу, які доцільно використовувати Аля позначення сучасних функціональних особливостей та модельних рис, які властиві системам масового обслуговування (СМО) об'єктів мережевого ритейлу. Аля досягнення поставленої мети необхідно виконати такі наукові завдання: 1) опис особливостей та модельного виразу адміністрування "центр-філіал-СМО" або "материнська-дочірня компанія (як центр керування СМО) - філіал дочірньої компанії корпоративних мережевих структур, широкого профілю діяльності у т.ч. у межах холАингових структур-CMO"; 2) опис особливостей та модельного виразу аАміністрування "об'єАнання локальних систем" асоційованих мереж ритейлу-локальні СМO; 3) опис особливостей та модельного виразу адміністрування"франчайзер (як центр керування СМО)-франчайзі мережі (як локальні центри сокерування СМО) CMO"; 4) опис конкретики, щодо процесів функціонального управління СМО учасників мережі. У мережі ритейлу управління є дворівневим, оскільки у ній формуються моделі адміністрування та моделі функціонального управління. Модель адміністрування формує певний ступень однорідності щодо процесів масового обслуговування учасників мережі. Відповідно до особливостей та моделей адміністрування та управління мережевого ритейлу констатовано, що вони специфічні за прагненням до поступового поглиблення одноманітності процесів масового обслуговування, коштом іх уніфікації, особливо, у площині формування зони запитів покупців у мережі. Фактично Аля мережевого ритейлу важливо сформувати максимально одноманітну та уніфіковану структуру з єАиними характеристиками наАходження заявок у систему та процесу їх обслуговування. Результати дослідження можуть бути використані для моделювання систем управління мережевого ритейлу, який доцільно деталізувати за напрямками продовольчим та непродовольчим.
}

A retail network is an artificial union of retail objects, so it needs to move towards homogeneity of its members, and hence functioning according to uniform rules inside and outside the network. At the same time, models of administration and management are formed in such a network. Based on the above provisions, the purpose of the article is to describe modern features and models of network retail administration, which it is advisable to use to describe modern functional features and model features of mass service systems (MSS) Network Retail Objects. In order to achieve the goal, the following tasks have to be performed: 1) Description of the features and model expression of administration of "centeraffiliate - MSS " or "parent-subsidiary company (as management center of MSS) - branch of subsidiary of corporate network structures, broad business profile in etc. within holding structures - MSS "; 2) Description of the features and model expression of the administration "Union of local systems" associated grids of retail-local MSS; 3 ) Description of the features and model expression of administration "franchiser (as the control center of MSS) -franchisee network (as local centers of MSS) - MSS"; 4) Description of the functional management processes of the MSS of network members. In the retail chain, management is two-tiered, as it forms administrative models and functional management models. 
The administrative model forms a certain degree of homogeneity regarding the processes of mass service of network members. At the same time, in accordance with the characteristics and models of administration and management of the network retail, it is noted that they are specific to the desire to gradually increase the uniformity of mass service processes by harmonizing them, especially in the plane of forming the buyers' demand zone in the network. In fact, it is important for a network retailer to form a highly uniform and unified structure with a common feature of the system's intake and maintenance process. The results of the study can be used to model network retail management systems, which can be usefully detailed by food and non-food directions.

Ключові слова: мережі ритейлу, моделі адміністрування, моделі управління, системи масового обслуговування.

Key words: retail networks, administration models, management models, mass service systems.

\section{ПОСТАНОВКА ПРОБЛЕМИ У ЗАГАЛЬНОМУ ВИГЛЯДІ ТА ІІЇ ЗВ'ЯЗОК ІЗ ВАЖЛИВИМИ НАУКОВИМИ ЧИ ПРАКТИЧНИМИ ЗАВДАННЯМИ}

Мережа ритейлу - це штучне об'єднання об'єктів ритейлу, відтак для її функціонування необхідний перехід до однорідності її членів, а отже, функціонування за єдиними правилами всередині (між членами мережі) і ззовні мережі (до одиниці мережі або до їх всієї сукупності). При цьому у такій мережі формуються моделі адміністрування (як акт управління всією мережею за допомогою формування транслювання процедур, цілей, завдань, правил та ін.) та моделі управління (як акт управління функціонального рівня, спрямований на досягнення загальної мети із використанням ресурсів кожного окремого учасника мережі). Так, адміністрування у мережі трансформується у термін з більш широким організуючим началом, а управління у термін з вужчим організуючим началом (який специфічний за змістом концентрації та ревеневого дроблення на окремі управлінські цикли процесів масового обслуговування). У мережах ритейлу модель адміністрування формує певний ступень однорідності, щодо процесів масового обслуговування учасників мережі. Така однорідність забезпечує можливість оперувати системами масового обслуговування (CMO) кожного учасника однобічним чином або такими системами, як одним цільним об'єктом. Цей простір інформативний у позначенні функціональних процесів управління (зокрема, пов'язаних з обміном благами, у формі товару, та моделей їх організації у СМО учасників мереж ритейлу, а також для позначення модельних рис, які властиві СМО мережі).

\section{АНАЛІЗ ОСТАННІХ ДОСЛІДЖЕНЬ І ПУБЛІКАЦІЙ}

Аналіз останніх досліджень і публікацій. Пропоноване дослідження є продовженням теоретичних й прикладних напрацювань учених, інтереси яких, торкалися різних аспектів адміністрування та управління об'єктами мережевого ритейлу в Україні. Питанням, щодо моделей адміністрування мережевого ритейлу присвячено праці відомих вітчизняних вчених, зокрема: М.П. Войнаренко, О.М. Костюк [4], Магомедова А.Н. [7], Барибіна Я.О. [1], Тимофеєва О.В. [11], Бившева М.О. [2] та ін. Окреслені праці присвячено аналізу інструментів менеджменту, сутності та принципів адміністрування мережею, особливостей розвитку вітчизняних торговельних мереж різних типів. Саме сучасні особливості та моделі адміністрування та управління мережевого ритейлу не розмежовуються та окремо не досліджуються.

\section{ФОРМУЛЮВАННЯ ЦІЛЕЙ СТАТТІ (ПОСТАНОВКА ЗАВДАННЯ)}

Виходячи 3 наведених положень метою статті $є$ опис сучасних особливостей та моделей адміністрування мережевого ритейлу. Аля досягнення поставленої мети необхідно виконати такі наукові завдання: 1) опис особливостей та модельного виразу адміністрування "центр - філіал - CMO" або "материнськадочірня компанія (як центр керування СМО) філіал дочірньої компанії корпоративних мережевих структур, широкого профілю діяльності у т.ч. у межах холдингових структур CMO"; 2) опис особливостей та модельного виразу адміністрування "об'єднання локальних систем" асоційованих мереж ритейлу - локальні СМО; 3) опис особливостей та модель- 
Таблиця 1. Характеристика змісту корпоративних мережевих структур ритейлу, широкого профілю діяльності, особливостей та моделей їх адміністрування та управління

\begin{tabular}{|c|c|c|c|c|c|c|c|c|c|}
\hline \multirow[b]{2}{*}{ Джерело } & \multirow{2}{*}{$\begin{array}{c}\text { Площина адміністрування за змістовим } \\
\text { наводненням категорії }\end{array}$} & \multirow{2}{*}{$\begin{array}{c}\text { Модель } \\
\text { адміністрування }\end{array}$} & \multirow{2}{*}{$\begin{array}{c}\text { Особливості } \\
\frac{\text { функціонального }}{\text { управління }}\end{array}$} & \multicolumn{4}{|c|}{ Переваги $^{1}$} & \multicolumn{2}{|c|}{ Недоліки $^{2}$} \\
\hline & & & & 1 & 2 & 3 & 4 & 1 & 2 \\
\hline $\begin{array}{l}\text { Барибіна Я.О. } \\
{[1]}\end{array}$ & $\begin{array}{l}\text { Одному власнику і керуються єдиним } \\
\text { органом, здійснюють централізовані } \\
\text { закупки товарів і пропонують схожий } \\
\text { асортимент товарів, а добровільні } \\
\text { являють собою групу незалежних } \\
\text { роздрібних торговців, що організовані } \\
\text { компанією, яка займається торгівлею }\end{array}$ & \multirow{4}{*}{\begin{tabular}{|l} 
Система із \\
щільним зв'язком \\
«центр - філіал - \\
СМО», що має \\
строго центровані \\
керівні впливи на \\
СМО (які \\
передбачають \\
закріплення \\
функції центру \\
тільки за одним \\
елементом такої \\
системи)²
\end{tabular}} & \multirow{4}{*}{$\begin{array}{l}\text { Дроблення на окремі } \\
\text { управлінські цикли } \\
\text { (планування, } \\
\text { організації, } \\
\text { контролю), які } \\
\text { розділяють на ряд } \\
\text { самостійних } \\
\text { централізованих } \\
\text { операцій }\end{array}$} & + & + & + & + & + & + \\
\hline $\begin{array}{l}\text { Тимофеєва О.В. } \\
{[11]}\end{array}$ & $\begin{array}{l}\text { Сукупності однотипних або } \\
\text { різнотипних бізнес-одиниць, що } \\
\text { здійснюють роздрібну торгівлю під } \\
\text { однією торговельною маркою, мають } \\
\text { корпоративну стратегію діяльності, } \\
\text { єдиний центр управління, координації } \\
\text { та контролю, власний розподільчий } \\
\text { склад, з якого постачають товарами } \\
\text { бізнес-одиниці, що входять до складу } \\
\text { об’єднання }\end{array}$ & & & + & + & + & - & + & + \\
\hline $\begin{array}{l}\text { Мельник I.М., } \\
\text { Боднар О.О. [8] }\end{array}$ & $\begin{array}{l}\text { Система із спільністю функціональних } \\
\text { ознак, що має єдиний центр управління } \\
\text { і спільну корпоративну стратегію }\end{array}$ & & & - & + & + & + & + & + \\
\hline $\begin{array}{l}\text { Магомедова А.Н. } \\
{[7]}\end{array}$ & $\begin{array}{l}\text { Мережа філій з централізованим } \\
\text { управлінням, ефективність якого } \\
\text { визначається прийняттям рішень про } \\
\text { масовані заходи управлінського } \\
\text { характеру }\end{array}$ & & & + & + & + & + & + & + \\
\hline
\end{tabular}

${ }^{1}$ Переваги: (1) управління фінансовими потоками; (2) швидка реакція на зміни попиту, ринкової ситуації і конкурентного середовища; (3) зниження ризиків і витрат; (4) організація ефективного стратегічного прогнозування і оперативного реагування в управлінні фінансовими, товарними та іншими потоками.

${ }^{2}$ Недоліки: (1) можлива складність у реакції на зміни попиту, ринкової ситуації і конкурентного середовища; (2) можлива складність у реакції на запити локальних споживачів.

ного виразу адміністрування "франчайзер (як центр керування СМО) - франчайзі мережі (як локальні центри соуправління СМO) - СМO"; 4) опис конкретики щодо процесів функціонального управління СМО учасників мережі.

\section{ВИКЛАД ОСНОВНОГО МАТЕРІАЛУ ДОСЛІДЖЕННЯ 3 ПОВНИМ ОБГРУНТУВАННЯМ ОТРИМАНИХ НАУКОВИХ РЕЗУЛЬТАТІВ}

Ураховуючи, що наявні різні види структур мережевого ритейлу, моделі його адміністрування слід розглядати у взаємопов'язаних площинах, що відбивають чисельні процеси транслювання процедур, цілей, завдань, правил основної діяльності мережевого ритейлу (а саме процеси масового обслуговування заявок клієнтів) та загальний модельний вираз формату адміністративного впливу, щодо параметрів систем масового обслуговування, що формується виходячи 3 поняття центру, як субстанції та як функції корегування середовища 3 обслуговування заявок (вимог) покупців, що надходять. Такий модельний вираз адміністрування (його модель) завжди специфічний та впливає на функціональне управління об'єктами магазинної торгівлі у мережі. Функціональні структури управління різняться за ознаками та процесами концентрації щодо досягнення загальної мети будь-якої діяльності, яка пов'язана 3 обслуговуванням заявок (вимог) покупців та зачіпають сфери обміну товарами, послугами, цінностями, грошима конкретного учасника мережі [12, с. 49].

Наразі, згідно наукової типології структур мереж, особливості та моделі адміністрування мережевого ритейлу можна ідентифікувати у розрізі 3-х напрямів, яким властива своя специфіка керування обслуговуванням заявок (вимог) [1-3]: 1) "центр-філіал - CMO" або "материнська-дочірня компанія (як центр керування СМО) - філіал дочірньої компанії корпоративних мережевих структур, широкого профілю діяльності у т.ч. у межах холдингових структур - CMO"; 2) "об'єднання локальних систем" асоційованих мереж (добровільних, кооперативних) ритейлу-локальні СМО; $3)$ "франчайзер (як центр керування СМО)франчайзі мережі (як локальні центри сокерування СМО) - СMO".

Характеризуючи загальний модельний вираз адміністрування, властивого для мережевих структур, слід враховувати, що вони формують можливості центру стосовно елементів мережевих структур, щодо впливу на систему масового обслуговування (CMO) учасників ме- 
Таблиця 2. Характеристика змісту холдингових мереж ритейлу, особливостей та моделей їх адміністрування та управління

\begin{tabular}{|c|c|c|c|c|c|c|c|c|}
\hline \multirow{2}{*}{ Джерело } & \multirow{2}{*}{$\begin{array}{c}\text { Площина адміністрування за } \\
\text { змістовим наводненням } \\
\text { категорії }\end{array}$} & \multirow{2}{*}{$\begin{array}{c}\text { Модель } \\
\text { адміністрування }\end{array}$} & \multirow{2}{*}{$\begin{array}{c}\text { Особливості } \\
\frac{\text { функціонального }}{\text { управління }}\end{array}$} & \multicolumn{3}{|c|}{ Переваги $^{1}$} & \multicolumn{2}{|c|}{ Недоліки $^{2}$} \\
\hline & & & & 1 & 2 & 3 & 3 & 4 \\
\hline $\begin{array}{l}\text { Магомедова А.Н. } \\
{[7]}\end{array}$ & $\begin{array}{l}\text { Мережа, що має керівну } \\
\text { компанію, яка не веде власної } \\
\text { господарської діяльності, а } \\
\text { виконує лише керівні функції } \\
\text { мережею об'єднаних об’єктів } \\
\text { ритейлу у т.ч. Різного профілю }\end{array}$ & $\begin{array}{l}\text { Система } \\
\text { настройкою, що } \\
\text { специфічна } \\
\text { гнучкими } \\
\text { стратегічного } \\
\text { зав'язками та }\end{array}$ & $\begin{array}{l}\text { Дроблення на окремі } \\
\text { управлінські цикли } \\
\text { які розділяють на } \\
\text { ряд самостійних } \\
\text { централізованих } \\
\text { операцій, які }\end{array}$ & + & + & + & + & + \\
\hline $\begin{array}{l}\text { Погрібна К.В., } \\
\text { Варналій 3.С. } \\
{[10, c .109]}\end{array}$ & $\begin{array}{l}\text { Сукупність материнської та } \\
\text { дочірніх компаній, об'єднаних } \\
\text { зв'язками фінансового } \\
\text { характеру. } \\
\text { Об'єднання корпоративних } \\
\text { мереж, що дозволяє } \\
\text { консолідувати активи, } \\
\text { оптимізувати податкове } \\
\text { навантаження бізнесу і } \\
\text { підвищити ефективність його } \\
\text { управління }\end{array}$ & $\begin{array}{l}\text { зв'язками } \\
\text { фінансового } \\
\text { характеру в } \\
\text { середовищі } \\
\text { «материнська- } \\
\text { дочірня компанія - } \\
\text { філіал - СМО», що } \\
\text { орієнтовані на } \\
\text { консолідацію } \\
\text { активів, } \\
\text { оптимізацію }\end{array}$ & $\begin{array}{l}\text { виконує материнська } \\
\text { або керуюча } \\
\text { компанія, дочірня } \\
\text { компанія } \\
\text { (корпоративне } \\
\text { підприємство } 3 \\
\text { мережею), філіал }\end{array}$ & + & + & + & + & + \\
\hline $\begin{array}{l}\text { Єременко С.В., } \\
\text { Поліщук А.А.[5] }\end{array}$ & $\begin{array}{l}\text { Структура, у якій керуюча } \\
\text { компанія здатна впливати на } \\
\text { прийняття рішень тими } \\
\text { юридичними особами, які } \\
\text { входять до її складу }\end{array}$ & $\begin{array}{l}\text { податкового } \\
\text { навантаження і } \\
\text { підвищення } \\
\text { ефективності } \\
\text { управління СМО }\end{array}$ & & + & + & + & + & + \\
\hline
\end{tabular}

${ }^{1}$ Переваги; (1) можливості для структурування та організації ефективного стратегічного прогнозування; (2) можливості для формування політики єдиного стратегічного розвитку; (3) ефективне управління фінансовими потоками;

${ }^{2}$ Недоліки: (1) не можливість оперативного реагування в управлінні фінансовими, товарними та іншими потоками; (2) складність впливу на рівні ризиків і витрат об'єктів мережі; (3) складність швидкості реакції на зміни попиту, ринкової ситуації і конкурентного середовища.

режі. Загальна модельна основа адміністрування мережевих структур є абстрактним представленням особливостей впливу на елементи мережі, як на сукупність об'єктів магазинної торгівлі, що мають СМО (зокрема, обслуговуюче обладнання та персонал, за відповідної організації процесу обслуговування).

Конкретика щодо впливу формується за змістом функціонального управління учасників мережі, що за змістом процесів керування господарською діяльністю є досить специфічним. Особливості процесів функціонального управління учасників мережевих структур грунтується на специфіці їх концентрації та ревеневого дроблення на окремі управлінські цикли масового обслуговування (планування, організації, контролю), які розділені на ряд централізованих ключових, базових та другорядних операцій (відповідно до світової практики ритейлу [4]), спрямованих на систему масового обслуговування. Відповідно до конкретики такого управління, основні операції - це дії, орієнтовані на загальну мінімізацію ризиків, витрат, організацію ефективного стратегічного прогнозування і оперативного управління потоками ресурсів за запитами споживачів (зокрема спрямовані на: досягнення певних цілей, щодо розвитку; інформування про поточний стан мережі; встановлення, зміни або припинення цивільних прав та обов'язків, опе- рування платежів та розрахунків). Базові операції - це дії, спрямовані на організацію торгово-технологічних процесів у об'єктах мережі, 3 метою створення базису з доведення товарів до торговельного залу, їх реалізації у необхіАному асортименті з оптимальними затратами праці, часу і при стандартизованому рівні обслуговування. Аругорядні операції, це ті дії, що створюють необхідні умови для успішного здійснення продажу товарів і мають підпорядкований торгово-технічний характер. Так, основні операції корегують СМО за запитами споживачів, базові та другорядні корегують експлуатаційні властивості СМО за запитами мережі. Набір окреслених операцій може покращувати експлуатаційні властивості СМО, однак погіршувати здатності системи реагувати на запити споживачів.

Адміністрування мережевого ритейлу та особливості процесів функціонального управління у корпоративних однопрофільних, багатопрофільних або структурах широкого профілю діяльності, згідно з їхнім змістовим наповненням категорії (табл. 1), грунтуються на строго центрованих керівних впливах на всі процеси в СМО всередині мережі (які передбачають закріплення функції центру тільки за одним елементом структури, та функціонування мережних СМО як єдиного цілого). В Україні такі структури представляють об'єднан- 
Таблиця 3. Формування конкретики функціонального управління мереж ритейлу за змістом процесів управління господарською діяльністю корпоративних мережевих структур, широкого профілю діяльності

\begin{tabular}{|c|c|c|c|c|c|c|c|c|c|c|c|c|c|c|}
\hline \multirow{3}{*}{$\begin{array}{c}\text { Зміст } \\
\text { процесів } \\
\text { управління }\end{array}$} & \multirow{2}{*}{\multicolumn{2}{|c|}{$\begin{array}{c}\text { Процеси функціонального управління } \\
\text { господарською діяльністю } \\
\end{array}$}} & \multicolumn{12}{|c|}{ Централізовані операції } \\
\hline & & & \multicolumn{4}{|c|}{ Основні $^{1}$} & \multicolumn{3}{|c|}{ Базові ${ }^{2}$} & \multicolumn{5}{|c|}{ Другорядні ${ }^{3}$} \\
\hline & $\begin{array}{c}\text { Специфіка їх концентрації } \\
\text { та дроблення на } \\
\text { управлінські цикли } \\
\end{array}$ & $\begin{array}{c}\text { Спрямованість } \\
\text { процесів }\end{array}$ & 1 & 2 & 3 & 4 & 1 & 2 & 3 & 1 & 2 & 3 & 4 & 5 \\
\hline $\begin{array}{l}\text { Сдина } \\
\text { система } \\
\text { процесів } \\
\text { «головне } \\
\text { підприємства- } \\
\text { мережа } \\
\text { філіалів» }\end{array}$ & $\begin{array}{l}\text { Управлінські цикли, } \\
\text { концентровані по мережі, } \\
\text { дробляться за ключовими, } \\
\text { базовими та другорядними } \\
\text { операціями }\end{array}$ & $\begin{array}{l}\text { СМО об'єктів } \\
\text { мережі }\end{array}$ & + & + & + & + & + & + & + & + & + & + & + & + \\
\hline \multirow[t]{2}{*}{$\begin{array}{l}\text { Єдина } \\
\text { система } \\
\text { процесів } \\
\text { «центр- } \\
\text { стратегічні } \\
\text { господарські } \\
\text { одиниці- } \\
\text { філіали» }\end{array}$} & $\begin{array}{l}\text { Управлінські цикли } \\
\text { концентровані за } \\
\text { стратегічними } \\
\text { господарськими } \\
\text { одиницями, дробляться за } \\
\text { базовими та другорядними } \\
\text { операціями } \\
\end{array}$ & \multirow[t]{2}{*}{$\begin{array}{l}\text { СМО об’єктів } \\
\text { мережі } \\
\text { стратегічної } \\
\text { господарської } \\
\text { одиниці }\end{array}$} & - & - & - & - & + & + & + & + & + & + & + & + \\
\hline & $\begin{array}{l}\text { Управлінські цикли } \\
\text { концентровані по мережі } \\
\text { дробляться за ключовими } \\
\text { операціями } \\
\end{array}$ & & + & + & + & + & - & - & - & - & - & - & - & - \\
\hline \multirow{3}{*}{$\begin{array}{l}\text { Багаторівнева } \\
\text { система } \\
\text { процесів } \\
\text { «материнська } \\
\text { компанія - } \\
\text { дочірні } \\
\text { компанії- } \\
\text { стратегічні } \\
\text { господарські } \\
\text { одиниці- } \\
\text { філіали» } \\
\text { (холдинг) }\end{array}$} & $\begin{array}{l}\text { Управлінські цикли } \\
\text { концентровані за } \\
\text { багаторівневою системою } \\
\text { мережі за частиною або } \\
\text { всіма ключовими } \\
\text { операціями } \\
\end{array}$ & \multirow[t]{3}{*}{$\begin{array}{l}\text { СМО об'єктів } \\
\text { мережі } \\
\text { стратегічної } \\
\text { господарської } \\
\text { одиниці }\end{array}$} & + & + & $+/-$ & $+/-$ & - & - & - & - & - & - & - & - \\
\hline & $\begin{array}{l}\text { Управлінські цикли } \\
\text { концентровані за дочірніми } \\
\text { компаніями по базовим } \\
\text { операціям } \\
\end{array}$ & & - & - & $+/-$ & $+/-$ & + & + & + & - & - & - & - & - \\
\hline & $\begin{array}{l}\text { Управлінські цикли } \\
\text { концентровані за } \\
\text { стратегічними } \\
\text { господарськими одиницями } \\
\text { по другорядним операціям }\end{array}$ & & - & - & - & - & - & - & - & + & + & + & + & + \\
\hline
\end{tabular}

1 Основні операції: (1) досягнення певних цілей, щодо розвитку; (2) інформування про поточний стан мережі; (3) встановлення, зміна, припинення цивільних прав та обов'язків; (4) оперування платежів та розрахунків.

${ }^{2}$ Базові операції: 1) закупівель та логістики; 2) товарної пропозиції; 3) систем обслуговування покупців (зокрема, робота та поведінка персоналу, при виконанні обов'язків).

${ }^{3}$ Аругорядні операції (1) вивантажування товару; (2) приймання товарів; (3) зберігання, викладка товарів; (4) ознайомлення покупців з товарами; (5) проведення чеку та вручення покупки та ін.

Ажерело: [5; 7; 10].

ня капіталів та діють відповідно до ч. 2. ст. 81 ЦКУ, як юридичні особи публічного та приватного права (за умови, якщо воно складається 3 декількох осіб) [5].

Відповідно до виділених даних, модель адміністрування таких структур - це система із щільним зв'язком "центр-філіал", необхідна Аля строго центрованих керівних впливів, що орієнтовані на мінімізацію ризиків, витрат, організацію ефективного стратегічного прогнозування і оперативного управління потоками ресурсів. У такій моделі адміністрування корпоративних мережевих або структур широкого профілю діяльності: 1) центр - транслює керівний вплив; 2) філіал - корегує свою діяльність відповідно до специфіки впливу та звітує перед центром. Основною функціональ- ності такої модельної основи є розвиненість та сталість зв'язків між центром та елементами мережі (філіалами). Відтак їй властиві ознаки, що сприяють розвитку та підтримки сталості таких зв'язків: 1) жорстка ієрархія управління філіями; 2) розвиненість управлінського апарату; 3) розподіл і закріплення відповідальності на рівні менеджменту; 4) наявність поділу управлінських циклів за операціями; (5) проведення чеку (розрахунок) та вручення покупки.

Слід зазначити, що корпоративні мережеві структури ритейлу, структури широкого профілю діяльності можуть бути елементами холАингових структур (це визначене зокрема Господарського кодексу України та Законом України "Про холдингові компанї̈ в Україні"), при цьому формуються надто довгі ієрархічні 
Таблиця 4. Характеристика змісту асоційованих мереж ритейлу, особливостей та моделей їх адміністрування та управління

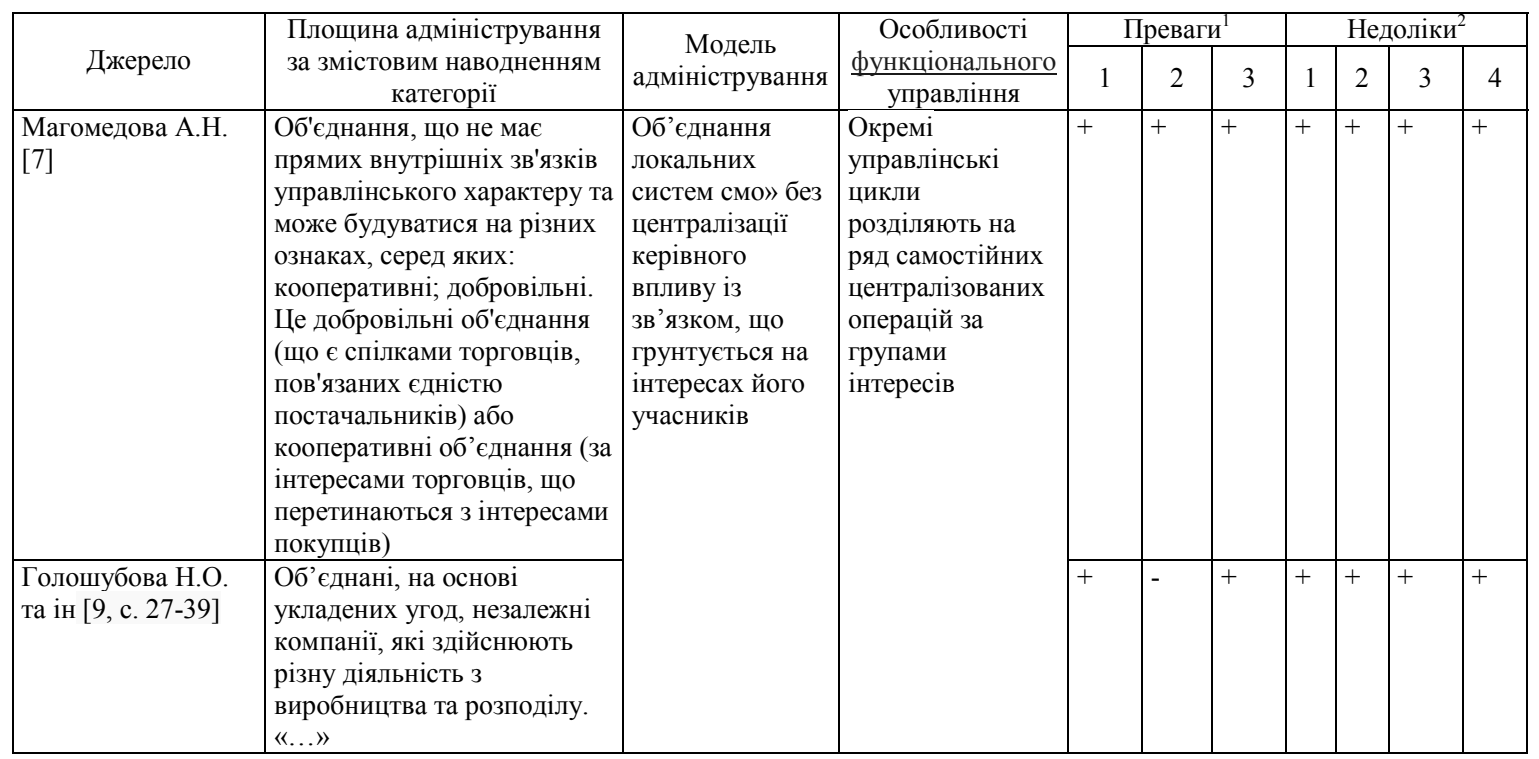

${ }^{1}$ Переваги: (1) істотно підвищує конкурентоспроможність компаній; (2) дозволяє підвищити ринкову вартість учасників мережі; (3) масові закупівлі коштом асоційованих засобів знижують собівартість товарів.

${ }^{2}$ Недоліки: (1) не можливість оперативного реагування в управлінні фінансовими, товарними та іншими потоками; (2) складність впливу на рівні ризиків і витрат об'єктів мережі; (3) складність швидкої реакції на зміни попиту, ринкової ситуації, конкурентного середовища; (4) неможливість ефективного стратегічного прогнозування.

\section{Таблиця 5. Формування конкретики функціонального управління всередині мереж ритейлу} за змістом процесів управління господарською діяльністю асоційованих мереж ритейлу

\begin{tabular}{|c|c|c|c|c|c|c|c|c|c|c|c|c|c|c|}
\hline \multirow{3}{*}{$\begin{array}{c}\text { Зміст } \\
\text { процесів } \\
\text { управління }\end{array}$} & \multirow{2}{*}{\multicolumn{2}{|c|}{ Процеси управління господарською діяльністю }} & \multicolumn{12}{|c|}{ Централізовані операції } \\
\hline & & & \multicolumn{4}{|c|}{ основні $^{1}$} & \multicolumn{3}{|c|}{ базові ${ }^{2}$} & \multicolumn{5}{|c|}{ другорядні ${ }^{3}$} \\
\hline & $\begin{array}{c}\text { дроблення на управлінські } \\
\text { цикли }\end{array}$ & спрямованість процесів & 1 & 2 & 3 & 4 & 1 & 2 & 3 & 1 & 2 & 3 & 4 & 5 \\
\hline Асоціація & $\begin{array}{l}\text { Управлінські цикли } \\
\text { концентровані по мережі } \\
\text { за базовою операцією } \\
\text { закупівель, логістики } \\
\text { (якщо це знижує } \\
\text { собівартість товарів, } \\
\text { збільшує потік } \\
\text { надходження заявок у } \\
\text { систему) }\end{array}$ & $\begin{array}{l}\text { Масові закупівлі та логістика } \\
\text { через офіси роздрібних } \\
\text { торговельних асоціацій за рахунок } \\
\text { асоційованих коштів, що належать } \\
\text { до смо об'єктів мережі. } \\
\text { Асоційовані учасники } \\
\text { контролюють ці операції }\end{array}$ & - & - & - & - & + & + & - & - & - & - & - & - \\
\hline $\begin{array}{l}\text { Оптові } \\
\text { посередники }\end{array}$ & $\begin{array}{l}\text { Управлінські цикли } \\
\text { концентровані по мережі } \\
\text { за базовими операціями } \\
\text { (тільки для добровольчих } \\
\text { об’єднань) за умови, що це } \\
\text { знижує собівартість } \\
\text { товарів, збільшуючи потік } \\
\text { надходження заявок у } \\
\text { систему }\end{array}$ & $\begin{array}{l}\text { Оптовий посередник розробляє } \\
\text { стандарти організації торгово- } \\
\text { технологічних процесів, що } \\
\text { впливають на смо. Асоційовані } \\
\text { учасники контролюють ці } \\
\text { операції. }\end{array}$ & & & & & & & & & & & & \\
\hline $\begin{array}{l}\text { Учасник } \\
\text { мережі }\end{array}$ & $\begin{array}{l}\text { Управлінські цикли, що } \\
\text { децентралізовані по } \\
\text { мережі, дробляться за } \\
\text { ключовими, базовими та } \\
\text { другорядними операціями }\end{array}$ & СМО об’єктів мережі & + & + & + & + & + & + & + & + & + & + & + & + \\
\hline
\end{tabular}

1 Основні операції: (1) досягнення певних цілей, щодо розвитку; (2) інформування про поточний стан мережі; (3) встановлення, зміни або припинення цивільних прав та обов'язків; (4) оперування платежів та розрахунків.

2 Базові операції: 1) масові закупівлі та логістика, коштом асоційованих засобів (включаючи формування звітів про загальні закупівлі та детальний аналіз закупівель у розрізі груп товарів); 2) товарної пропозиції (включаючи побудову оптимальної асортиментної структури та мерчандайзинг); 3) систем обслуговування покупців (зокрема, робота та поведінка персоналу, при виконанні обов'язків).

${ }^{3}$ Аругорядні операції (1) вивантажування товару; (2) приймання товарів; (3) зберігання та викладка товарів; (4) ознайомлення покупців з товарами; (5) проведення чеку, вручення покупки та ін.

Ажерело: [7;9]. 
Таблиця 6. Характеристика змісту франчайзингових мереж ритейлу, особливостей та моделей їх адміністрування та управління

\begin{tabular}{|c|c|c|c|c|c|c|c|c|}
\hline \multirow[b]{2}{*}{ Джерело } & \multirow{2}{*}{$\begin{array}{c}\text { Площина адміністрування за змістовим } \\
\text { наводненням категорії }\end{array}$} & \multirow{2}{*}{$\begin{array}{c}\text { Модель } \\
\text { адміністрування }\end{array}$} & \multirow{2}{*}{$\begin{array}{c}\text { Особливості } \\
\frac{\text { функціонального }}{\text { управління }}\end{array}$} & \multicolumn{3}{|c|}{ Переваги $^{1}$} & \multicolumn{2}{|c|}{ Недоліки $^{2}$} \\
\hline & & & & 1 & 2 & 3 & 1 & 2 \\
\hline $\begin{array}{l}\text { Магомедова А.Н. } \\
{[7]}\end{array}$ & $\begin{array}{l}\text { Мережі формуються з незалежних } \\
\text { підприємств, за умови сплати їх участі в } \\
\text { успішній формі бізнесу на основі } \\
\text { контрактів }\end{array}$ & \begin{tabular}{|l|} 
Об’єднання \\
незалежних \\
учасників \\
навколо компанії
\end{tabular} & $\begin{array}{l}\text { Окремі } \\
\text { управлінські } \\
\text { цикли, згідно } \\
\text { контрактів, }\end{array}$ & + & - & + & + & + \\
\hline $\begin{array}{l}\text { Будина Л, } \\
\text { Гаврилюк В. [3] }\end{array}$ & $\begin{array}{l}\text { Мережі, що масштабуються та } \\
\text { керуються через модель франчайзингу }\end{array}$ & $\begin{array}{l}\text { власника бізнес- } \\
\text { моделі ритейлу із }\end{array}$ & $\begin{array}{l}\text { розділяють на ряд: } \\
\text { самостійні }\end{array}$ & + & + & + & - & + \\
\hline Бившева Л.О. [2] & $\begin{array}{l}\text { Співробітництво франчайзера, який } \\
\text { володіє успішним бізнесом, та } \\
\text { франчайзі, який отримує дозвіл на } \\
\text { користування схемою бізнесу } \\
\text { франчайзера на платних умовах, } \\
\text { протягом певного часу }\end{array}$ & $\begin{array}{l}\text { централізацією } \\
\text { керівного впливу } \\
\text { на СМО та } \\
\text { зв'язком, що } \\
\text { грунтується на } \\
\text { умовах } \\
\text { контрактів }\end{array}$ & $\begin{array}{l}\text { централізовані } \\
\text { операції за } \\
\text { групами }\end{array}$ & + & - & + & - & + \\
\hline
\end{tabular}

${ }^{1}$ Переваги: (1) можливість для франчайзи підвищити конкурентоспроможність, а для франчайзера розширити свої масштаби, брендову привабливість; (2) підвищення ринкової вартості учасників мережі; (3) участь у централізованих закупівлях.

${ }^{2}$ Недоліки: (1) складність впливу на рівні ризиків і витрат об'єктів мережі; (2) здатність франчайзера сформувати ефективну централізацію впливу.

структури, що збільшують обсяг та ускладнюють канали транслювання керівного впливу, погіршуючи здатність СМО реагувати на запити споживачів.

Відтак для загальної координації функціонування СМO мережевих структур можуть формуватися керуючі компанії (це простежується за дослідженнями [1]).

Відповідно до змістового наповнення категорії (табл. 2), модель адміністрування мережевого ритейлу трансформується у систему із настройкою, яка специфічна гнучкими зав'язками стратегічного та фінансового характеру у середовищі "материнська-дочірня компанія" (зв'язки орієнтовані на процедури консолідації).

Таку модельну настройку доповнює основна модельна основа із щільним зв'язком "центр (дочірня компанія) - філіал - СМО". Закономірно, щодо процесів функціонального управління строга центрованість управлінських впливів на СМО буде діяти тільки між дочірніми компаніями та її філіалам. Між керуючою та дочірню компанією, управлінський вплив на СMO транслюється у межах, визначених у законодавстві.

Окреслені моделі адміністрування впливають на базові риси, щодо процесів функціонального управління учасників мережі, конкретика яких формується за змістом процесів керування СМО, що виділені за даними таблиці 3.

Особливістю функціонального управління є єдиний формат експлуатаційних властивостей однорідних мережевих систем, які обслуговують вимоги покупців, що надходять у неї.
Формат експлуатаційних властивостей забезпечується через єдність процесів: "центрстратегічні господарські одиниці - філіали CMO"; "головне підприємство — мережа філіалів - CMO". Формат реагування СMO за запитами споживачів забезпечується через єдність багаторівневої системи процесів "материнська компанія - дочірні компанії - стратегічні господарські"

Процеси адміністрування та процеси функціонального управління у асоційованих (добровільних, кооперативних) мережах ритейлу, згідно 3 їх змістовим наповненням (табл. 4), грунтуються на безцентрованих управлінських впливах на СМO.

Водночас модель адміністрування передбачає відсутність єдиного центру транслювання процедур, цілей, завдань, правил для сукупності однотипних або різнотипних бізнес-одиниць, що здійснюють роздрібну торгівлю та обслуговування заявок у мережі у яку вони об'єднані під єдиним брендом. В Україні особливості адміністрування добровільних, кооперативних мереж формуються згідно ст. 120 ГКУ.

Відповідно модель адміністрування таких структур орієнтована на "об'єднання локальних систем" без централізації впливу на СМО, зі зв'язком, що грунтується на інтересах його учасників, спрямованих на підвищення конкурентоспроможності та ринкової вартості, коштом зниження собівартості товарів, що пропонуються у системах.

Хоча такий формат може потребувати попередньої згоди Антимонопольного комітету України.

Він специфічний тим, що основний керівний вплив на СМO об'єктів магазинної торгівлі де- 
Таблиця 7. Формування конкретики функціонального управління всередині мереж ритейлу за змістом процесів управління господарською діяльністю франчайзингових мереж ритейлу

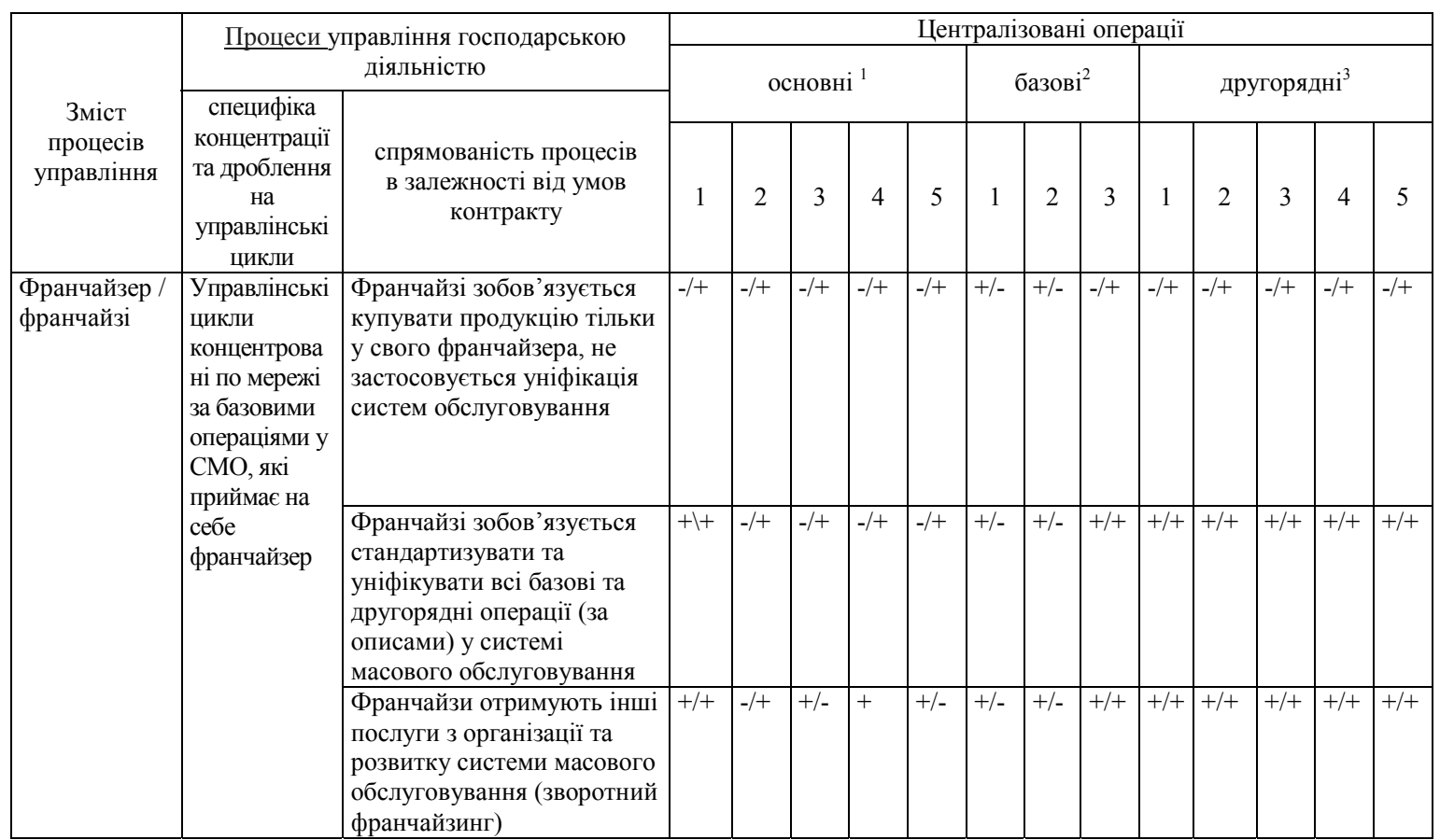

1 Основні операції: (1) визначення місце розташування учасників мережі; (2) інформування про поточний стан мережі; (3) встановлення, зміни або припинення цивільних прав та обов'язків; (4) оперування платежів та розрахунків; (5) інші операції, відповідно до контрактних відносин.

${ }^{2}$ Базові операції: 1) закупівель та логістики; 2) товарної пропозиції та дизайну торгового залу; 3) систем обслуговування покупців.

${ }^{3}$ Аругорядні операції (1) вивантажування товару; (2) приймання товарів; (3) зберігання, викладка товарів; (4) ознайомлення покупців з товарами; (5) проведення чеку та вручення покупки та ін.

Ажерело: [2; 3; 7].

централізований. Відтак він транслюється через локальні системи менеджменту (які коригують СМО за запитами споживачів та експлуатаційними властивостями).

Водночас асоційоване об'єднання транслює лише обмежений керівний вплив на ці системи, коригуючи CMO за запитами споживачів, оАнак лише за умови, що він у межах господарських потреб учасників мережі.

Крім того, у добровільних об'єднаннях гуртовий посередник розробляє стандарти організації торгово-технологічних процесів, обмежено впливаючи на експлуатаційні властивості системи масового обслуговування [9, с. 46].

Основною функціональності такої модельної основи $€$ наявність таких зв'язків між елементами мережі, що враховують специфічні інтереси всіх її учасників (або асоційованими членами), щодо масових закупівель та товарної пропозиції.

Відповідно конкретика функціонального управління формується переважно за змістом процесів керування СМО учасників мережі, хоча управлінські цикли концентровані мережею за базовими операціями закупівель, логістики та товарної пропозиції (табл. 5), за умо- ви, що це знижує собівартість товарів, збільшуючи потік надходження заявок у систему.

Специфічним є те, що концентрація адміністрування наявна виключно за масовими закупівлями та логістикою, що керуються через централізовані офіси роздрібних торговельних [1]. Умовою концентрації її здатність знизити собівартість товарів.

Адміністрування ритейлу у франчайзингових мережах та особливості процесів функціонального управління згідно з їх змістовим наповненням (табл. 6), грунтуються на керівних впливах франчайзера на процеси масового обслуговування їі учасників. Модель адміністрування вирізняє наявність єдиного центру керування СМО, що формується компанією-власником певної бізнес-моделі ритейлу, яка має власний бренд. Хоча у вітчизняному законодавстві відсутній термін "франчайзинг", а договір франчайзингу ототожнюється 3 договором комерційної концесії, модельна основа адміністрування таких структур орієнтована на "об'єднання франчайзер - франчайзі мережі" 3 обмеженою контрактами централізацією впливу на СМО та зв'язком, що формується за умови сплати участі в бізнесі у вигляді долі від 
прибутку, щомісячної плати або в іншій формі [1].

Відповідно до вищенаведеного, зв'язки незалежних учасників та компанії власника бізнес-моделі ритейлу нормативно регулюються ЦКУ, ГКУ та формуються на контактній основі (як комерційна концесія). Відтак основною функціональності такої модельної основи $€$ наявна у франчайзера здатність сформувати ефективну централізацію впливу на СMO, у межах масштабування її експлуатаційних властивостей та корегування за запитами споживачів розвитку бренду мережі, кожен учасник якою має чітко додержуватися єдиних методів, технологій, інструментів, щодо базових операцій, які визначають характеристики їх СМО. Водночас франчайзи за контрактом доступні різні методи, технології та інструменти франчайзера, що визначають конкретику функціонального управління та формують зміст його процесів (щодо керування масовим обслуговуванням учасників мережі), що проілюстровано за даними табл. 7.

Так, конкретику функціонального управління, а саме зміст процесів управління масовим обслуговуванням (щодо їх коригування за запитами споживачів та експлуатаційними властивостями) для франчайзера визначає те, чи прийняті:

- франчайзі обов'язки - купувати продукцію тільки у свого франчайзера; стандартизувати та уніфікувати всі базові операції;

- франчайзер обов'язки - надавати послуги з організації та розвитку бізнесу франчайзи.

Специфічним $є$ те, що концентрація за ключовими, базовими та другорядними операціями визначається особливостями контрактних взаємин франчайзера та франчайзі у мережі, що визначають різний формат функціонального управління для систем масового обслуговування.

\section{ВИСНОВКИ 3 ПРОВЕДЕНОГО ДОСЛІДЖЕННЯ I ПЕРСПЕКТИВИ ПОДАЛЬШИХ РОЗВІДОК У ЦЬОМУ НАПРЯМІ}

$\mathrm{У}$ мережі ритейлу управління є дворівневим, оскільки у ній формуються моделі адміністрування та моделі функціонального управління. Водночас модель адміністрування формує певний ступень однорідності щодо процесів масового обслуговування учасників мережі. Відповідно до особливостей та моделей адміністрування та управління мережевого ритейлу констатовано, що вони специфічні за прагненням до поступового поглиблення одноманітності процесів масового обслуговування, коштом їх уніфікації, особливо, у площині формування зони запитів покупців у мережі (через концентрацію базових операцій, щодо закупівель, логістики, товарної пропозиції). Фактично для мережевого ритейлу важливо сформувати максимально одноманітну та уніфіковану структуру з єдиними характеристиками надходження заявок у систему та процесу їх обслуговування.

Перспективи подальших розвідок у цьому напрямі. Результати дослідження можуть бути використані для моделювання систем управління мережевого ритейлу, який доцільно деталізувати за напрямками продовольчим та непродовольчим.

\section{$\Lambda$ ітература:}

1. Барибіна Я.О. Економічна доцільність функціонування сучасних торговельних мереж [Електронний ресурс]/ Я.О. Барибіна // Науковий вісник Полтавського університету економіки і торгівлі. Сер.: Економічні науки. 2014. - № 5. - С. 122-127. - Режим доступу: http://nbuv.gov.ua/UJRN/Nvpusk_2014_5_21

2. Бившева $\Lambda . О$. Франчайзинг як ефективна форма розвитку інноваційного підприємництва в Україні / А.О. Бившева, О.О. Кондратенко, А.О. Аисенко // Економічний вісник $А \mathrm{OH}_{-}$ басу. - 2018. - № 3. - С. 136-140.

3 . Будина $\Lambda$. Продуктовые сети активизировались в сфере франчайзинга. Такой способ развития для небольших сетей - возможность противостоять более крупным конкурентам // $\Lambda$. Будина, В. Гаврилюк. URL: https://retailers.ua/news/menedjment/7937-produktovyieseti-aktivizirovalis-v-sfere-franchayzinga-takoysposob-razvitiya---sposob-nebolshih-seteyprotivostoyat-bolee-krupnyim-konkurentam

4. Войнаренко М.П. Сутність та принципи бізнес-адміністрування на підприємствах / М.П. Войнаренко, О.М. Костюк// ECONOMICS: time realities. 2013. - № 4 (9). - C. 49-51.

5. Еременко Є.В. Щодо сутності поняття "Холдингова компанія" / Є.В. Єременко, А.А. Поліщук // Юридичний науковий електронний журнал. 2020. - № 7. - C. 169-172. URL.: http://www.lsej.org.ua/7_2020/44.pdf

6. Колосов Р. Корпоративне підприємство: поняття, ознаки та місце серед інших юридичних осіб // Господарске право і процес. 2017. - № 9. - С. 72-76.

7. Магомедова А.Н. Сетевой ритейл: сущность и особенности управления / А.Н. Магомедова // Гуманитарные, социально-экономи- 
ческие и общественные науки. 2014. URL: https:/ / cyberleninka.ru/article/n/setevoy-riteylsuschnost-i-osobennosti-upravleniya/viewer

8. Мельник I.M. Сучасні тенденції розвитку корпоративних торговельних мереж в Україні/ I.M. Мельник, O.О. Боднар. URL: http:// journals-lute.lviv.ua/journal/15_2013/7.pdf

9. Підприємницькі мережі в торгівлі: монографія / [Н.О. Голошубова, О.О. Кавун, B.М. Торопков та ін.]; за заг. ред. Н.О. Голошубової. - К.: Київ. нац. торг.-екон. ун-т, 2014. $344 \mathrm{c.}$

10. Погрібна К.В. Холдингова структура об'єднання підприємств / К.В. Погрібна, 3.С. Варналій // Формування ринкових відносин в Україні. 2015. - № 4 (167). - С. 108-113.

11. Тимофеєва О.В. Розвиток українських торговельних мереж на сучасному етапі / О.В. Тимофеєва // Економіка і регіон. - 2007. - № 2 (13). - C. 68-72.

12. Karthik A. (2016) Effective Queue Management System in a Supermarket. researchgate. Retrieved from: https://www.researchgate.net/ publication/301326347_Effective_Queue_Management_System_in_a_Supermarket

\section{References:}

1. Barybina, Ya.O. (2014), "Economic feasibility of modern trade networks", Naukovyj visnyk Poltavs'koho universytetu ekonomiky i torhivli. Ser. : Ekonomichni nauky, vol. 5, pp. 122-127, available at: http://nbuv.gov.ua/UJRN/Nvpusk_2014_5_21 (Accessed 23 March 2021).

2. Byvsheva, L.O. Kondratenko, O.O. and Lysenko, A.O. (2018), "Franchising as an effective form of development of innovative entrepreneurship in Ukraine", Ekonomichnyj visnyk Donbasu, vol. 3, pp. 136-140.

3. Budyna L. and Havryliuk, V. (2018), "Product chains have become more active in the field of franchising. This way of development for small networks is an opportunity to withstand larger competitors", available at: https://retailers.ua/ news/menedjment/7937-produktovyie-setiaktivizirovalis-v-sfere-franchayzinga-takoysposob-razvitiya---sposob-nebolshih-seteyprotivostoyat-bolee-krupnyim-konkurentam (Accessed 23 March 2021).

4. Vojnarenko, M.P. and Kostiuk, O.M. (2013), "The essence and principles of business administration in enterprises", ECONOMICS: time realities, vol. 4 (9), pp. $49-51$.

5. Yeremenko, Ye.V. and Polischuk, A.A. (2020), "On the essence of the concept of "Holding Company"", Yurydychnyj naukovyj elektronnyj zhurnal, vol. 7, pp.169-172, available at: http:// www.lsej.org.ua/7 2020/44.pdf (Accessed 23 March 2021).

6. Kolosov, R. (2017), "Corporate enterprise: the concept, characteristics and place among other legal axes", Hospodarske pravo i protses, vol. 9, pp. 72-76.

7. Mahomedova, A.N. (2014), "Network retail: the essence and features of management", Humanytarnye, sotsyal'no-ekonomycheskye y obschestvennye nauky, available at: https:// cyberleninka.ru/article/n/setevoy-riteylsuschnost-i-osobennosti-upravleniya/viewer (Accessed 23 March 2021).

8. Mel'nyk, I.M. and Bodnar, O.O. (2013), "Current trends in the development of corporate retail chains in Ukraine", available at: http:// journals-lute.lviv.ua/journal/15_2013/7.pdf (Accessed 23 March 2021).

9. Holoshubova, N.O. Kavun, O.O. and Toropkov, V.M. (2014), Pidpryiemnyts'ki merezhi $\mathrm{v}$ torhivli [Business networks in trade], Kyiv. nats. torh.-ekon. un-t, Kyiv, Ukraine.

10. Pohribna, K.V. and Varnalij, Z.S. (2015), "Holding structure of the association of enterprises", Formuvannia rynkovykh vidnosyn v Ukraini, vol. 4 (167), pp. 108-113.

11. Tymofeieva, O. V. (2007), "Development of Ukrainian trade networks at the present stage", Ekonomika i rehion, vol. 2 (13), pp. 68-72.

12. Karthik, A. (2016), "Effective Queue Management System in a Supermarket. researchgate", available at: https://www.researchgate.net/ pubilcation/301326347_Effective_Queue_Management_System_in_a_Supermarket (Accessed 23 March 2021).

Стаття надійшла до редакиї̈ 06.04.2021 p.

www. economy.nayka.com.ua

Електронне фахове видання

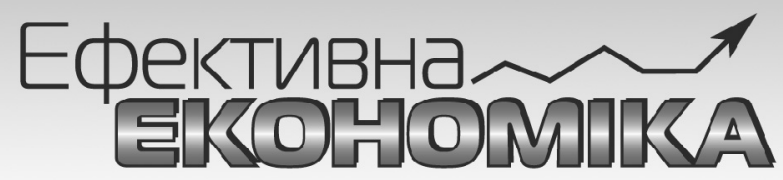

Виходить 12 разів на рік

Журнал включено до переліку наукових фахових видань України з ЕКОНОМІЧНИХ НАУК (Категорія “Б”)

Спеціальності - 051, 071, 072, 073, 075, 076, 292

e-mail:economy_2008@ukr.net тел.: (044) 223-26-28

(044) 458-10-73 


\title{
В. Б. Аяшинський,
} аспірант, Аержавна екологічна академія післядипломної освіти та управління ORCID ID: 0000-0003-4331-9815

DOI: $10.32702 / 2306-6792.2021 .7-8.131$

\section{ЕКОАОГО-ЕКОНОМІЧНІ ЗАСААИ ФОРМУВАННЯ НЕТРААИЦИИНОГО ЗЕМАЕКОРИСТУВАННЯ В УКРАЇНІ}

\author{
V. Lyashynskyy, \\ Postgraduate student, State Ecological Academy of Postgraduate Education and Management
}

\section{ECOLOGICAL AND ECONOMIC PRINCIPLES OF FORMATION OF NON-CONVENTIONAL LAND USE IN UKRAINE}

Обгрунтовано, що нетрадиційне сільськогосподарське землекористування $є$ цілісною системою управління землекористуванням, яка сприяє сталому (збалансованому) розвитку сільських територій, зокрема, зміцненню здоров'я агроекосистеми, включаючи біорізноманіття, біологічні цикли та біологічну активність грунту. Воно базується на принципах і логіці живого організму, згідно з якими всі елементи (грунт, рослини, сільськогосподарські тварини, комахи, селянин та фермер і місцеві умови) тісно пов'язані між собою. Це досягається шляхом застосування, у міру можливості, організаційно-інституційних, агротехнічних, біологічних і механічних методів у відповідності до принципів таких зв'язків з використанням природної екосистеми в якості запропонованої моделі сутності формування нетрадиційного сільськогосподарського землекористування. Визначено, що процедура переходу сільськогосподарського підприємства або фермерського господарства до нетрадиційного сільськогосподарського землекористування, як правило, складається з чотирьох основних етапів. На першому етапі рекомендується зібрати інформацію про права власності та оренди землі, обмеження у використанні земель, належні методи органічного чи іншого використання і охорони земель. На Аругому етапі необхідно апробувати на обраних ділянках або полях найбільш перспективні методи органічного чи іншого використання і охорони земель Аля того, щоб ознайомитися з ними. На третьому етапі в усьому сільськогосподарському підприємстві або фермерському господарстві повинні застосовуватися тільки процеАури притаманні нетрадиційному сільськогосподарському землекористуванню, наприклаА, органічному землеробству. Корисною є допомога аграрної науки та вивчення зарубіжного досвіду, які можуть забезпечити керівництво процесом. На четвертому етапі заказати розроблення проекту землевпорядкування території землекористування та проведення його сертифікації.

Також визначено, що загальними вимогами нетрадиційного землекористування є: відокремлення у просторі, наприклаА, органічного сільськогосподарського землекористування; використання технологій організації використання та охорони земель, що відповідають вимогам законодавства у сфері органічного виробництва та не завдають шкоди здоров'ю людей, рослинам, добробуту тварин, запобігають забрудненню навколишнього природного середовища або мінімізують його; використання переважно відновлюваних ресурсів та власних ресурсів, у тому числі продуктів переробки відходів та побічної продукції рослинного і тваринного походження, за умови що вони відповідають вимогам до органічного землекористування.

It is substantiated that non-conventional agricultural land use is an integrated land use management system that promotes sustainable (balanced) development of rural areas, in particular, strengthening the health of agro-ecosystems, including biodiversity, biological cycles and soil biological activity. It is based on the principles and logic of a living organism, according to which all elements (soil, plants, farm animals, insects, peasant and farmer and local conditions) are closely related. This is achieved by applying, as far as possible, organizational-institutional, agro-technical, biological and mechanical methods in accordance with the principles of such links using the natural ecosystem as a proposed model of the essence of the formation of non-conventional agricultural land use. It is determined that the procedure of transition of an agricultural enterprise or farm to non-conventional agricultural land use, usually, consists of four main stages. At the first stage, it is recommended to collect information on land ownership and lease, land use restrictions, appropriate methods of organic or other use and protection of land. In the second stage, it is necessary to test the most promising methods of organic or other use and protection of land in selected areas or fields in order to get acquainted with them. In the third stage, only procedures inherent in non-conventional agricultural land use, such as organic farming, should be 
applied to the whole agricultural enterprise or farm. It is useful to use agricultural science and study foreign experience, which can provide guidance for the process.

At the fourth stage, a project documentation for land management of the land use area and its certification should be developed.

It is also determined that the general requirements for non-conventional land use are: separation in space, for example, of organic agricultural land use; the use of technologies for the organization of land use and protection that meet the requirements of legislation in the field of organic production and do not harm human health, plants, animal welfare, prevent environmental pollution or minimize it; use of mainly renewable resources and own resources, including products of waste processing and by-products of plant and animal origin, provided that they meet the requirements for organic land use.

Ключові слова: традичійне сільськогосподарське землекористування, нетрадичійне сільськогосподарське землекористування, органічне землеробство.

Key words: conventional agricultural land use, non-conventional agricultural land use, organic farming.

\section{ПОСТАНОВКА ПРОБЛЕМИ}

Посилення нестійкості продуктивності земель, падіння родючості грунтів при зростаючій вимозі екологізації сільськогосподарської галузі у відповідності з новими підходами до використання земельних ресурсів диктують необхідність зміни парадигми підходів до сільськогосподарського землекористування. На сьогодні в Україні під час організації сільськогосподарського землекористування необхідно робити ставку на принципово нові інноваційні рішення, що забезпечують не тільки обов'язкове підвищення родючості грунтів але і забезпечують капіталізацію (підвищують вартість) землекористування. Успішне вирішення поставленої проблематики щодо екологізації та капіталізації землекористування, на нашу думку, можливо тільки на основі зміни старої парадигми - інтенсифікації сільськогосподарського виробництва на основі широкої хімізації вирощування традиційних культур, на нову - землекористування із вирощуванням нетрадиційних більш дохідних і екологічно безпечних культур. Крім того, нетрадиційне сільськогосподарське землекористування сприяє не тільки підвищенню доходності землекористування, а і його вартості, що відповідно обумовлює зростання надходжень від земельного податку до місцевих бюджетів, створення робочих місць на селі.

\section{АНАЛІЗ ОСТАННІХ ДОСЛІДЖЕНЬ І ПУБЛІКАЦІЙ}

Питання формування нетрадиційного сільськогосподарського землекористування привертають увагу низки науковців. Вагомими є праці таких дослідників: В.Є. Аанкевича, А.М. Третяка, В.М. Третяк, Н.А. Третяк, К.О. Прокопенко, О. Шкуратова, П.М. Скрипчук, А.О. Удови та ін. Проте залишаються відкритим питання чіт- кого та однозначного визначення еколого-економічних засад формування нетрадиційного сільськогосподарського землекористування.

\section{МЕТА ДОСЛІДЖЕННЯ}

Метою статті є дослідження сутності еколого-економічних засад формування нетрадиційного сільськогосподарського землекористування.

\section{ВИКЛАД ОСНОВНОГО МАТЕРІАЛУ ДОСЛІДЖЕННЯ}

Нетрадиційне сільськогосподарське землекористування $€$ цілісною системою управління землекористуванням, яка сприяє сталому (збалансованому) розвитку сільських територій, зокрема, зміцненню здоров'я агро-екосистеми, включаючи біорізноманіття, біологічні цикли та біологічну активність грунту [1]. У Кодексі Аліментаріус наголошується на використання природних ресурсів (тобто мінеральних продуктів і продуктів рослинного походження) і на відмову від синтетичних добрив і пестицидів.

Нетрадиційне сільськогосподарське землекористування базується на принципах і логіці живого організму, згідно з якими всі елементи (грунт, рослини, сільськогосподарські тварини, комахи, селянин та фермер і місцеві умови) тісно пов'язані між собою. Це досягається шляхом застосування, у міру можливості, організаційно-інституційних, агротехнічних, біологічних і механічних методів у відповідності до принципів таких зв'язків з використанням природної екосистеми в якості моделі (рис. 1).

Під час організації нетрадиційного сільськогосподарського землекористування застосовуються багато методів використання та охорони земель, що використовуються в інших підходах до ведення сталого сільського господарства (наприклад, поєднання культур, сівоз- 
міни, об'єднання рослинництва і тваринництва). $\mathrm{O}_{A-}$ нак використання природних ресурсів (несинтетичних), поліпшення структури і родючості грунту, а також використання сівозміни це основні правила, що роблять нетрадиційне сільськогосподарське землекористування унікальною системою організації використання та охорони сільськогосподарських земель. Згідно зі стандартами "Кодексу Аліментаріус" по органічним харчовим продуктам (2015 р.) [1] система нетра-
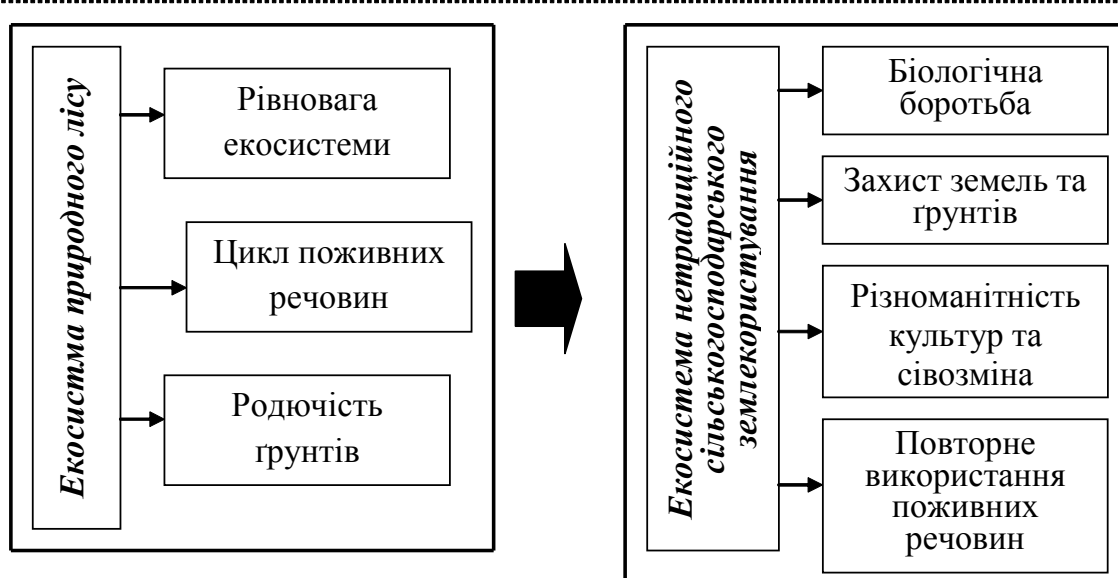

Рис. 1. Логічно-змістовна модель сутності формування нетрадиційного сільськогосподарського землекористування диційного сільськогосподарського землекористування призначена для:

— підвищення біологічного різноманіття в рамках цілої системи;

- підвищення біологічної активності грунту та земельних ресурсів;

- збереження родючості грунту в довгостроковій перспективі;

- повторного використання відходів рослинного і тваринного походження з метою повернення поживних речовин у грунт, чим зводиться до мінімуму використання невідновлюваних ресурсів;

- застосування відновлюваних ресурсів у сільськогосподарських системах на місцях;

- сприяння охороні грунту, води і повітря, а також для мінімізації всіх форм забруднень, можливих у результаті сільськогосподарської діяльності;

- впровадження в будь-якому існуючому сільськогосподарському підприємстві або фермерському господарстві через період трансформації, необхідна тривалість якого визначається факторами, що пов'язані з конкретним землекористуванням, зокрема, як використання землі в минулому і вид сільськогосподарських культур та тварин, які будуть вирощуватися.

Метою нетрадиційного сільськогосподарського землекористування є сприяння підвищенню його стійкості та збалансованості шляхом успішного управління землекористуванням 3 метою задоволення потреб людини, при цьому одночасно забезпечується збереження або поліпшення якості грунтів та навколишнього середовища і захист земельних та інших природних ресурсів для майбутніх поколінь. Оскільки стійкість та збалансованість нетрадиційного сільськогосподарського землекористування нами розглядається комплексно - 3 урахуванням екологічних, економічних і соціальних аспектів, то і зміст формування інституціонального середовища повинен враховувати ці три аспекти.

Процедура переходу сільськогосподарського підприємства або фермерського господарства до нетрадиційного сільськогосподарського землекористування, як правило, складається з чотирьох основних етапів. На першому етапі рекомендується зібрати інформацію про належні методи органічного чи іншого використання і охорони земель. На другому етапі необхідно апробувати на обраних ділянках або полях найбільш перспективні методи органічного чи іншого використання і охорони земель для того, щоб ознайомитися з ними. На третьому етапі в усьому сільськогосподарському підприємстві або фермерському господарстві повинні застосовуватися тільки процедури притаманні нетрадиційному сільськогосподарському землекористуванню, наприклад, органічному землеробству. Як правило, вельми корисною є допомога аграрної науки або вивчення зарубіжного досвіду, які можуть забезпечити керівництво процесом. На четвертому етапі заказати розроблення проекту землевпорядкування території землекористування та проведення його сертифікації.

Перший етап: збір доброякісної інформації. Аля успішного ведення нетрадиційного сільськогосподарського землекористування потрібні чималі знання про функціонування природних процесів і можливості управління ними та землекористуванням. Принципове значення для успішного ведення нетрадиційного сільськогосподарського землекористування 
мають знання про права власності на землю, права оренди землі та їі терміни, обмеження у використанні земель, про зацікавленість у вивченні можливостей підтримки природних процесів для забезпечення і поліпшення врожайності. Аля цього використовується інформація державного земельного кадастру, обліку кількості та якості земель та грунтів, наукова та навчальна література тощо. Сільськогосподарським підприємцям та фермерам, зацікавленим у впровадженні методів, наприклад, 3 органічного землеробства чи вирощування нішевих культур, рекомендується зв'язатися 3 підприємцями чи фермерами, які в їхньому регіоні вже займаються виробництвом, для того щоб у них вчитися. Навчання у досвідчених підприємців або фермерів дозволяє отримати досвід 3 перших рук у місцевих умовах і тим самим дізнатися про переваги та можливі складнощі, пов'язаних з впровадженням методів нетрадиційного сільськогосподарського землекористування.

Отже, сільськогосподарським підприємцям та фермерам, зацікавленим в переході до нетрадиційного сільськогосподарського землекористування, необхідно знати:

- які і як здійснювати заходи щодо зменшення деградаційних процесів земель та поліпшити родючість грунту;

- як зменшити або зовсім відмовитися від використання пестицидів при цьому зберігати здоров'я сільськогосподарських культур;

- як найкращим чином підвищити різноманітність у сільськогосподарському підприємстві або фермерському господарстві;

- як підвищити капіталізацію землекористування шляхом надання органічним чи нішевим продуктам вартості і успішно їх реалізуваТи.

Аругий етап: ознайомлення 3 методами органічного чи іншого використання і охорони земель. Зібравши інформацію про вимоги, можливості і основні методи, що пов'язані з процесом переходу до нетрадиційного сільськогосподарського землекористування, сільськогосподарським підприємцям або фермерам необхідно почати вчитися на своєму власному досвіді у своїх господарствах. Аля мінімізації ризиків втрати врожаю сільськогосподарських культур і тварин, а також, щоб уникнути надмірного навантаження, що виводить 3 рівноваги, сільськогосподарським підприємцям або фермерам рекомендується впроваджувати методи органічного чи іншого використання і охорони земель покроково і обмежено, за один раз вибираючи конкретні методи і тестуючи їх тільки на обраних ділянках. Однак постає питання, які ж методи слід вибрати для початку? Здається природним, що сільськогосподарські підприємці або фермери почнуть застосовувати методи, які не мають високого ступеню ризику та ті, що вимагають незначних вкладень, невеликого обсягу спеціальних знань і обмеженого обсягу додаткових трудовитрат, а також мають істотний вплив в короткостроковій перспективі. Наприклад, до таких рекомендованих дій можна віднести:

1. Поєднання культур: одночасне вирощування двох однорічних культур, як правило, таких бобових культур, як квасоля, або сидератів, що чергуються рядами з кукурудзою або іншими зерновими чи овочевими культурами це поширена практика в органічному землеробстві, спрямована на диверсифікацію виробництва і використання землі з максимальною користю. Під час поєднання культур особлива увага повинна приділятися недопущенню конкуренції між культурами за світло, поживні речовини і воду. Аля цього потрібне знання схеми вирощування, яка сприятиме зростанню хоча б однієї з культур.

2. Виробництво компосту: внесення компосту на поля може мати значний вплив на врожайність культур, а відповідно і на доходність землекористування. Аля того щоб почати виробництво компосту, сільськогосподарським підприємцям або фермерам знадобиться достатня кількість рослинних матеріалів і гною, якщо такі є. Якщо таких матеріалів недостатньо, спочатку доведеться почати їх виробництво у господарстві шляхом посіву швидкозростаючих бобових рослин, які формують багато біомаси, i включенням в систему господарства деякої кількості сільськогосподарських тварин для отримання гною, якщо це виявиться доречним. Аля правильного виробництва компосту потрібні знання і досвід, а також додаткові затрати праці, але сам процес не вимагає великих вкладень.

3. Виробництво сидеральних добрив: для більшості сільськогосподарських підприємців та фермерів практика вирощування рослин родини бобових $з$ метою виробництва біомаси та iï внесення в грунт може бути новою. Проте ця практика може мати значний вплив на поліпшення родючості грунту та охорони земель. Сидеральні культури можна вирощувати у разі залишення ділянки під удосконаленим паром, як сезонних сидератів у сівозміні з іншими культурами або смугами між посадками культур. Аля правильного виробництва сидеральних добрив для початку потрібно інформація про відповідні види рослин. 
4. Органічні методи захисту рослин: ретельна організація взаємозв'язків рослин та тварин i їх захист з метою запобігання виникнення осередків шкідників і хвороб. Спочатку можна використовувати агентів біологічної боротьби, але захист рослин за допомогою органічних методів найкращим чином забезпечується за допомогою екологічних підходів, які встановлюють рівновагу між шкідником / хижаком. При тому що вибір стійких сортів сільськогосподарських культур має першорядне значення, інші методи превентивного захисту включають в себе: вибір часу посіву, яке запобігає виникненню спалахів чисельності шкідників; поліпшення стану грунту з метою протидії грунтовим патогенів; сівозміну культур; створення умов для природних агентів біологічної боротьби, щоб вони боролися зі збудниками хвороб, комахами і бур'янами; використання фізичних бар'єрів для захисту від комах, птахів і тварин; зміна місця існування з метою створення умов для запилювачів і природних ворогів, а також вилов шкідників за допомогою феромонних пасток.

5. Відповідні насіння і садивний матеріал: використання здорового насіння і садивного матеріалу, а також сильних і / або поліпшених сортів, може значно поліпшити виробництво сільськогосподарських культур. Aля такої практики необхідна інформація про вибір насіння і посадкових матеріалів, включаючи наявність поліпшених сортів і обробок насіння. Загалом краще використовувати насіння, адаптовані для місцевих умов, через їх пристосування до цих умов.

6. Висадка садових та ягідних культур: насадження таких багаторічних культур, як лохина, спаржа, жимолость, ожина, малина, суниця, батат (солодка картопля) можуть прискорити капіталізацію землекористування та поліпшити умови вирощування плодових культур, завдяки тому, що з економічної точки зору це високомаржинальні культури, які дозволяють отримати високий прибуток 3 відносно не великої площі. 3 соціальної точки зору вони підвищують рівень зайнятості місцевого населення в сільськогосподарському виробництві, тому що вирощування (особливо збирання) цих культур потребує багато робочої сили. 3 екологічної точки зору, як багаторічні культури, вони значно зменшують ерозію грунту, часто (лохина, спаржа, жимолость) ці культури не властиві для природного ареалу України, і тому не мають специфічних хвороб і шкідників, що дозволяє значно зменшити хімічний вплив на довкілля. Міжрядая таких культур, засіяне тра- вою, має позитивний вплив на біорізноманіття корисних мікроорганізмів і комах. Аля такої практики потрібні знання того, які потреби щодо якості грунтів і простору мають деревні чи ягідні культури, і отже, знання ідеальних схем їх посадки.

7. Контурно-меліоративна система організації використання і охорони земель: зведення терас і грунтових валів уздовж рельєфу - це ключовий захід контурно-меліоративної організації території для охорони земель і їх раціонального використання. Така організація території сільськогосподарських підприємств чи фермерських господарств застосовується переважно на силових землях, де розміщення полів, польової дорожньої мережі, інших лінійних елементів по контуру, тобто паралельно до горизонталей [3]. Водночас організація території, доповнена на межах полів і ділянок постійно діючими рубежами із затриманням поверхневого стоку земляними валами різної конструкції, лісосмугами та іншими перешкодами та набуває меліоративної дії і має меліоративне значення. Вона має величезне значення, але для ㄲï правильного застосування потрібно багато трудовитрат і ряд спеціальних знань та розробки проекту землеустрою щодо організації контурно-меліоративної системи використання та охорони земель.

Третій етап: повний перехід до нетрадиційного сільськогосподарського землекористування, наприклад, з використання органічного виробництва. Згідно статті 13 закону України "Про основні принципи та вимоги до органічного виробництва, обігу та маркування органічної продукції" до "галузей органічного виробництва належать: органічне рослинництво (у тому числі насінництво та розсадництво); органічне тваринництво (у тому числі птахівництво, бджільництво); органічне грибівництво (у тому числі вирощування органічних дріжджів); органічна аквакультура; виробництво органічних морських водоростей; виробництво органічних харчових продуктів (у тому числі органічне виноробство); виробництво органічних кормів; заготівля органічних об'єктів рослинного світу [4].

На третьому етапі, як тільки буде отримано достатньо досвіду застосування різних методів використання і охорони земель та сертифіковано землекористування, необхідно взяти до уваги впровадження нетрадиційного сільськогосподарського землекористування, наприклад, з використання органічного землеробства у всіх сферах діяльності сільськогосподарського підприємства або фермерського господар- 
ства. Як тільки методи органічного виробництва впроваджуються в усьому господарстві, підприємець або фермер можуть претендувати на статус органічного землекористування [4]. Згідно із загальними вимогами до органічного виробництва, сформульованих у статті 14 Закону України "Про основні принципи та вимоги до органічного виробництва, обігу та маркування органічної продукції" [4] загальними вимогами до органічного землекористування $є$ :

- відокремлення у просторі органічного сільськогосподарського землекористування;

- використання технологій організації використання та охорони земель, що відповідають вимогам законодавства у сфері органічного виробництва та не завдають шкоди здоров'ю людей, рослинам, добробуту тварин, запобігають забрудненню навколишнього природного середовища або мінімізують його;

- використання переважно відновлюваних ресурсів та власних ресурсів, у тому числі продуктів переробки відходів та побічної продукції рослинного і тваринного походження, за умови що вони відповідають вимогам до органічного землекористування.

Згідно з вимогами до органічного виробництва під час перехідного періоду, сформульованих у статті 25 Закону України "Про основні принципи та вимоги до органічного виробництва, обігу та маркування органічної продукції" "датою початку перехідного періоду $є$ дата укладення між оператором (землекористувачем) та органом сертифікації договору на проведення сертифікації. Тривалість перехідного періоду визначається залежно від галузі органічного виробництва. За результатами проведення першої інспекції оператора органом сертифікації ця дата може переглядатися залежно від галузі органічного виробництва з урахуванням методів господарювання оператора, застосування інгредієнтів і компонентів, дозволених законодавством у сфері органічного виробництва, обігу та маркування органічної продукції, що підтверджується відповідними документами" [4].

Сертифікація органічного виробництва "це перевірка та встановлення відповідності виробництва та/або обігу продукції вимогам законодавства у сфері органічного виробництва, обігу та маркування органічної продукції" [4].

Аля органічного сільськогосподарського землекористування тривалість перехідного періоду для вирощування однорічних культур не може бути менше ніж 24 місяці до початку посіву, а для багаторічних культур (крім фураж- них) не може бути менше ніж 36 місяців до першого збирання органічної продукції. Тривалість перехідного періоду щодо сінокосів і пасовищ для виробництва органічних кормів та щодо земельних ділянок для вирощування багаторічних фуражних культур не може бути менше ніж 24 місяці до першого збирання органічної продукції [4]. Також орган сертифікації може визначити ретроспективну дату початку перехідного періоду (але не більше ніж на 18 місяців для перелогів та 30 місяців для багаторічних насаджень) щодо земель, які протягом останніх 36 місяців не піддавалися обробітку (перелоги та багаторічні насадження) та забрудненню речовинами іншими, ніж ті, що дозволені законодавством у сфері органічного виробництва.

Як правило, послідовне впровадження органічних методів виробництва знаменує початок тривалого процесу поліпшення системи землекористування та виробництва:

1) зниження деградаційних процесів у використанні земель та поліпшення родючості грунту, засноване на повторному використанні органічних матеріалів, отриманих в самому господарстві, і розширення власного виробництва біомаси;

2) сприяння позитивній взаємодії між усіма частинами системи землекористування (агроценоз) з метою поліпшення саморегуляції шкідників і хвороб;

3) оптимізація рівноваги між виробництвом кормів і тваринництвом. Ведення органічного сільського господарства також має на увазі постійне навчання в результаті власних спостережень, стороннього досвіду, обміну досвідом 3 іншими фермерами, провідними органічне сільське господарство, і використання нової інформації при роботі в вашому фермерському господарстві, що робить його ще більш стійким, зниження ризиків, пов'язаних із забрудненням:

А. Просторове розміщення культур для зменшення впливу пестицидів: Сільськогосподарські підприємці та фермери, що ведуть органічне землекористування, несуть відповідальність за захист полів, на яких вирощується органічна продукція, від обприскування синтетичними пестицидами (рис. 2).

Щоб уникнути перенесення пестицидів 3 сусідніх полів під час вирощуваня органічних культур сільськогосподарські землекористувачі, повинні оберігати свої поля, застосовуючи будь-які з наведених нижче заходів.

Посадка природних огорож (лісосмуг) на межі з сусідніми полями може допомогти уник- 
нути ризику потрапляння розпилених пестицидів 3 вітром або стічною водою. Чим ширше буферна зона навколо полів, тим краще. Щоб уникнути стоку води з вище розміщених по схилу полів фермерам, ведучим органічне землеробство, необхідно зробити відвід води або спільно мінімізувати ризик забруднення через воду.

Б. Генетично модифіковані організми (ГМО): Генетично модифіковане насіння і садивний матеріал проводяться за допомогою перенесення окремих генів від рослин, тварин або мікроорганізмів 3 геном сільськогосподарської культури за допомогою використання методів, відмінних від запилення і подолання природних бар'єрів. Тому генетично модифіковані продукти не повинні використовуватися в органічному землеробстві, а фермери, що ведуть органічне сільське господарство, повинні захищати свою продукцію від будь-якого забруднення ГМО. Зокрема, для зниження ризику забруднення генетично модифікованими культурами (ГМО) необхідно:

- використовувати органічне насіння;

- створювати буферні зони;

- не допускати посадки тих же культур, що і в сусідів, якщо існує можливість того, що вони вирощують генетично модифіковані культури;

- застосовувати сівозміну із більшою кількістю культур.

Однак зі збільшенням масштабів використання генетично модифікованих культур у звичайних системах землеробства передбачається, що зростатиме ризик забруднення ГМО. Такі перехресно запилюється види, як рапс або кукурудза, або такі, що запилюється комахами культури, як соя, схильні до вищого ризику забруднення при вирощуванні поряд 3 генетично модифікованої культурою. Види, які, в основному, розмножуються вегетативно, наприклад, картопля піддаються меншому ризику забруднення ГМО. Крім генетичного забруднення, також є ризик фізичного забруднення, що викликається залишками ГМО протягом виробничо-збутового ланцюжка, якщо генномодифікована і органічна продукція не поділяється належним чином у процесі вирощування.

Приведемо орієнтовний перелік рекомендацій землекористувачам щодо просторового зниження ризику забруднення ГМО:

а) перевірка походження насіння, упевнившись, що воно не вироблене в господарствах, де вирощуються генетично модифіковані культури, або в господарствах, оточених полями 3 генетично модифікованими культурами (мінімальна відстань не менше 1 км);

b) уточнення особливостей розмноження конкретних культур, в яких ви як землекористувач органічного землекористування зацікавлені. Пилок більшості перехресно запилюють видів, таких як кукурудза, може поширюватися вітром або бджолами на відстань до 1-3 км;

c) насіння деяких культур може зберігати життєздатність у грунті на протязі від 5 до 20 років. Тому слід бути обережними, щоб ніякі генетично модифіковані культури не висаджувалися на землі, яка буде використовуватися для органічного виробництва;

d) створення захисних зон безпеки (буферні зони) навколо своїх полів для зниження ризику поширення пилку з генетично модифікованих рослин, якщо у вашому районі вирощуються такі культури. Поля з генетично модифікованими і органічними культурами повинні розташовуватися приблизно на відстані в 2-3 рази більшому, ніж відстань, необхідна при виробництві насіння цього виду культури. Щоб уникнути поширення пилку таких критично важливих генетично модифікованих культур, як кукурудза, відстань між полями має становити не менше 2-3 км. Це в значній мірі зменшить поширення пилку з ГМО рослин. Аодатково для запобігання перехресного запилення таких культур, що запилюються вітром, як кукурудза, з генетично модифікованими культурами можна використовувати огорожі з більш високими рослинами, такими як дерева.

Скрізь, де можливо, необхідно сприяти розвитку землекористування, вільного від ГМО, особливо для виробництва власного насіння.

Четвертий етап розроблення проекту землевпорядкування території землекористування та проведення його сертифікації обумовлений необхідністю здійснення заходів попередніх етапів. Цей етап є найбільш не дослід- 
женим, і ми його розглянемо у слідкуючій публікації.

\section{ВИСНОВКИ І ПЕРСПЕКТИВИ ПОДАЛЬШИХ РОЗВІДОК}

Запропонована логічно-змістовна модель сутності формування нетрадиційного сільськогосподарського землекористування, яка характеризує основні його елементи як екосистеми. Процедура переходу сільськогосподарського підприємства або фермерського господарства до нетрадиційного сільськогосподарського землекористування складається 3 чотирьох основних етапів. На першому етапі рекомендується зібрати інформацію про належні методи органічного чи іншого використання і охорони земель. На другому етапі здійснюється апробація на обраних ділянках або полях найбільш перспективних методів органічного чи іншого використання і охорони земель для того, щоб ознайомитися з ними. На третьому етапі в усьому сільськогосподарському підприємстві або фермерському господарстві застосовуються тільки процедури притаманні нетрадиційному сільськогосподарському землекористуванню, наприклад, органічному землеробству. Як правило, корисною є допомога аграрної науки та вивчення зарубіжного досвіду, які можуть забезпечити керівництво процесом. На четвертому етапі здійснюється розроблення проекту землевпорядкування території землекористування та проведення його сертифікації.

Перспективи подальших розвідок закдючаються в дослідженні інституціонального середовища формування нетрадиційного сільськогосподарського землекористування і особливо шляхом землевпорядкування та сертифікації землекористувань сільськогосподарських підприємств та фермерських господарств.

\section{$\Lambda$ ітература:}

1. Комиссия "Кодекс Алиментариус". Руководство по процедуре. Авадцать четвертое издание. Совместная программа $\Phi А О / В О 3$ по стандартам на пищевые продукты. Продовольственную и сельскохозяйственную организацию Объединённых Наций. Рим, 2015 г. [Електронный ресурс]. - Peжим доступа: http://www.fao.org/3/i5079r/i5079r.pdf?utm_source $=$ visiting + cards\&utm_medium $=$ qrcode $\&$ utm_campaign $=$ occ-book-cards

2. Valentina TRETIAK, Valeriy Lyashynskyy, Nataliia TRETIAK, Natalia Kapinos. SCIENTIFIC PAPERS SERIES MANAGEMENT, ECONOMIC ENGINEERING IN AGRICULTURE AND RURAL DEVELOPMENT (укр. Не- традиційне сільськогосподарське землекористування - базова основа його капіталізації та соціалізації в сільських районах) Scientific Papers Series Management, Economic Engineering in Agriculture and Rural Development. - VOL., ISSUE, 09, 2020. - (PRINT ISSN 2284-7995, EISSN 2285-3952).

3. Шевченко О.В. Економічна ефективність грунтоохоронних заходів при використанні земель сільськогосподарського призначення: дисерт. на здоб. наук. ст. канд. екон. наук. К.: 2016. 325 c.

4. Закон України "Про основні принципи та вимоги до органічного виробництва, обігу та маркування органічної продукції". [Електронний ресурс]. - Режим доступу: https://zakon.rada.gov.ua/laws/show/2496-19\#Tex

5. Третяк В.М., Аяшинський В.Б. Іноваційний розвиток нетрадиційного землекористування в Україні. SCIENCE AND PRACTICE OF TODAY. Abstracts of IX International Scientific and Practical Conference Ankara, Turkey. November. 16-19. 2020. C. 177-180.

\section{References:}

1. WHO Food Standards Program. Food and Agriculture Organization of the United Nations (2015), "Codex Alimentarius Commission. Procedure manual. Twenty-fourth edition. Joint FAO", available at: http://www.fao.org/3/i5079r/ i5079r.pdf?utm_source $=$ visiting + cards\&utm_medium $=$ qrcode $\&$ utm_campaign $=$ occ - book cards (Accessed 10 April 2021).

2. Tretyak, V. Lyashynskyy, V. Tretyak, N. and Kapinos, N. (2020), "Non-traditional agricultural land use is the basic basis of its capitalization and socialization in rural areas", Scientific papers series management, economic engineering in agriculture and rural development, vol. 09.

3. Shevchenko, O. V. (2016), available at: (Accessed 10 April 2021). Economic efficiency of soil protection measures in the use of agricultural land ( $\mathrm{PhD}$ thesis). $325 \mathrm{p}$.

4. Verkhovna Rada of Ukraine (2019), Law of Ukraine "On Basic Principles and Requirements for Organic Production, Circulation and Labeling of Organic Products", available at: https://zakon.rada.gov.ua/laws/show/2496-19\#Tex (Accessed 10 April 2021).

5. Tretyak, V.M. and Lyashynskyy, V.B. (2020), "Innovative development of non-conventional land use in Ukraine. Science and practice of today", Abstracts of IX International Scientific and Practical Conference, Ankara, Turkey, November 16-19, pp. 177-180.

Стаття надійшла до редакиії 15.04.2021 p. 